UNIVERSIDADE DE SÃO PAULO

FACULDADE DE FILOSOFIA, LETRAS E CIÊNCIAS HUMANAS

DEPARTAMENTO DE HISTÓRIA

PROGRAMA DE PÓS-GRADUAÇÃO EM HISTORIA SOCIAL

ADRIANA MARIA PINHEIRO MARTINS PEREIRA

\title{
A cultura amadora na virada do século XIX: a fotografia de Alberto de Sampaio (Petrópolis/Rio de Janeiro, 1888-1914)
}


UNIVERSIDADE DE SÃO PAULO

FACULDADE DE FILOSOFIA, LETRAS E CIÊNCIAS HUMANAS

DEPARTAMENTO DE HISTÓRIA

PROGRAMA DE PÓS-GRADUAÇÃO EM HISTORIA SOCIAL

\section{A cultura amadora na virada do século XIX: a fotografia de Alberto de Sampaio (Petrópolis/Rio de Janeiro, 1888-1914)}

Adriana Maria Pinheiro Martins Pereira

Tese apresentada ao Programa de Pós-Graduação em História Social do Departamento de História da Faculdade de Filosofia, Letras e Ciências Humanas da Universidade de São Paulo, para a obtenção do título de Doutor em História.

Orientador:

Prof. Dr. Ulpiano Toledo Bezerra de Meneses

V.1

São Paulo

2010 


\title{
Resumo
}

Este trabalho tem por objetivo analisar a cultura amadora fotográfica na virada do século XIX, tendo como contexto Petrópolis e Rio de Janeiro e tomando como fio condutor a produção e atuação de Alberto de Sampaio, um advogado e apaixonado fotógrafo amador, pertencente à elite da cidade serrana. São examinados os integrantes dessas atividades, suas qualificações sociais e culturais, práticas e objetivos, competência (econômica, material, técnica e outras), seus produtos, usos e funções, referenciais (critérios, normas, valores e seus veículos), suas formas de associação e interação. Três séries de fotografias - tematizando a natureza, a família e a cidade permitem concluir que fotografar não era um registro documental mas uma prática comunicacional, completada pela circulação familiar e entre amigos, homens cultivados e refinados, sedimentando laços e garantindo solidariedade, tudo alimentado pelo afeto, pela diversão, pelo lúdico e pelo humor. Era um propósito que não poderia assentar-se em outros fundamentos, como os de natureza política, econômica e profissional.

PALAVRAS-CHAVE: Fotografia, Fotografia Amadora, Fotoclube, Petrópolis, Alberto de Sampaio

\begin{abstract}
This piece of work aims to analize the amateur photographic culture in the turning of the Nineteenth century, using as context Petropolis and Rio de Janeiro and taking as guiding principles Alberto Sampaio's production and performance, a lawyer and passionate amateur photographer, who was part of the mountain range city's elite. It will be examined the components of such activities, their social and cultural qualifications, practices and objectives, competence (economical, material, technical and others), their products, uses and functions, frames of reference(criteria, rules, values and their vehicles), their forms of association and interaction. Three series of photographies using as a theme, the nature, the family, and the city - allow to conclude that photographing was not a documentation recording, but a communication practice, completed by the circulation in family and among friends, refined and educated men, settling bonds and assuring solidarity, everything powered by affection, by enjoyment, by the ludic, by humour. It was a purpose that could not be settled in other basic rules as of political, economical or professional natures.
\end{abstract}

KEY WORDS: Photography, Amateur Photography, Photo Club, Petropolis, Alberto de Sampaio. 


\section{Agradecimentos}

Devo agradecimentos a diversas pessoas que tiveram participação fundamental, em vários momentos desse trabalho:

Agradeço ao meu orientador, Prof. Ulpiano Toledo Bezerra de Meneses. Ao longo destes últimos anos seus ensinamentos, observações, leituras rigorosas e atenciosas, e sua vastíssima cultura em diversos campos do conhecimento contribuíram para o entendimento que hoje tenho sobre o trabalho de pesquisa.

Eduardo Soares de Sampaio Filho, neto de Alberto de Sampaio que, pela sua grande generosidade, tornou possível este trabalho. Eduardo Sampaio revirou armários, identificou fotografias e me contou por diversas vezes histórias de seus familiares. Pudemos então recompor trajetórias, encontros, restabelecer elos, enfim, começar a compreender aquelas imagens.

Evaldo Macedo, fotógrafo membro da SOPEF - Sociedade Petropolitana de Fotografia - está também desde o início dessa pesquisa. Ele digitalizou as fotografias, álbuns, identificou imagens, pesquisou em jornais e revistas. $\mathrm{O}$ apoio desse grande amigo contribuiu significativamente para o enriquecimento deste trabalho.

À Profa. Solange Ferraz de Lima, pelo incentivo e comentários valiosos quando o trabalho ainda era um projeto. Aos Profs. Vânia Carneiro de Carvalho e Marcos Silva pelas observações, críticas construtivas e sugestões no exame de qualificação. À Profa. Ana Maria Mauad com quem pude aprender muitas coisas no momento inicial desta pesquisa. À Profa. Tamara Egler, por todo o apoio quando este ainda era um projeto embrionário. À Profa. Icléia Thiesen, pelo constante estímulo e amizade.

Aos Profs. Heliana Angotti Salgueiro e Christian Joschke. Ao Prof. Eduardo Morettin. À Mariza da Silva Gomes, chefe do Arquivo Histórico da Biblioteca Municipal Gabriela Mistral de Petrópolis. À Sociedade Petropolitana de Fotografia SOPEF. Ao Instituto de Estudos Brasileiros (IEB) da USP. Aos descendentes dos fotógrafos amadores aqui referidos, que me forneceram importantes informações, incorporadas à pesquisa: Estela Cordeiro Guerra, Heidys Portella Barroso Neto e João Bevilacqua. E à CAPES, pelo auxílio fornecido para o desenvolvimento do trabalho.

Aos amigos Denise Belotto, Mônica Schmidt, Davi Levy e Carlos Kessel.

À minha família que está sempre presente em meus momentos importantes - aos meus pais Leone e José e minha irmã Isabela. E ao Léo, por todo carinho e apoio ao longo de todos esses anos. Ele foi ouvinte dessas histórias e de cada descoberta, com quem compartilhei os momentos mais árduos e também de muitas alegrias. 


\section{Sumário}

INTRODUÇÃ

FONTES

CAPÍTULO 1. BALANÇO HISTORIOGRÁFICO.............................................................15

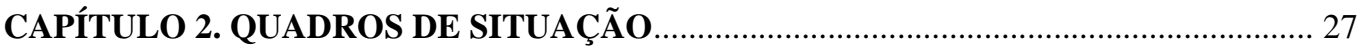

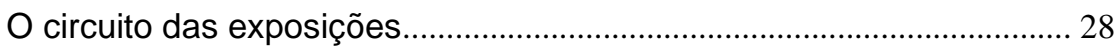

Propostas pedagógicas............................................................................ 29

Os modelos: manuais, jornais e revistas estrangeiras.............................. 33

A Renascença e o Photo-Club do Rio de Janeiro........................................41

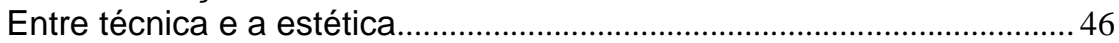

A Kodak e a fotografia............................................................................. 55

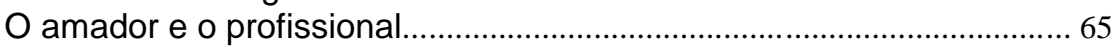

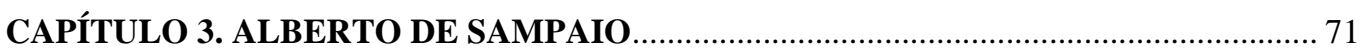

A personagem ............................................................................... 71

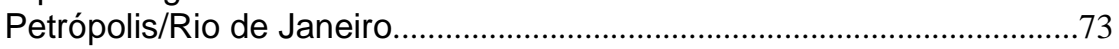

Alberto de Sampaio e a fotografia amadora.............................................. 90

Petrópolis: cidade da pose........................................................................ 96

CAPÍTULO 4. A PRODUÇÃO AMADORA DE ALBERTO DE SAMPAIO...................... 105

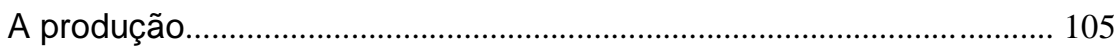

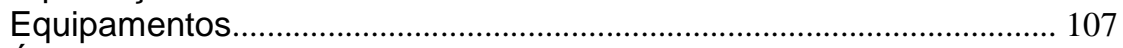

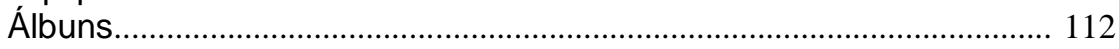

As séries temáticas............................................................................ 114

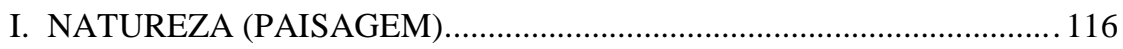

A natureza como objeto de estranhamento/desfrute..............................119

A natureza como mobiliário cênico........................................................ 129

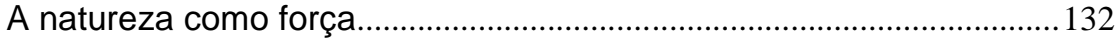

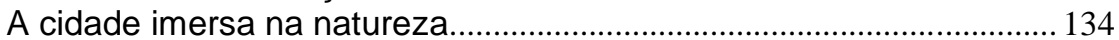

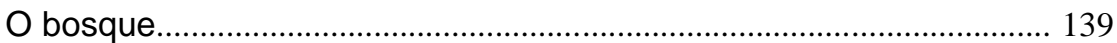

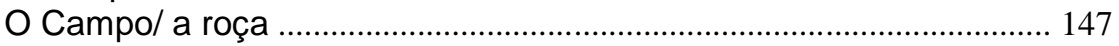

Paisagem industrial............................................................................. 158

A natureza como marca de distinção...................................................... 166

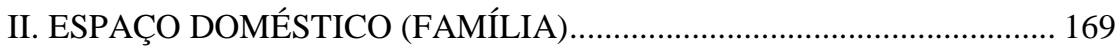

Os espaços e os atores da fotografia de família...................................... 173

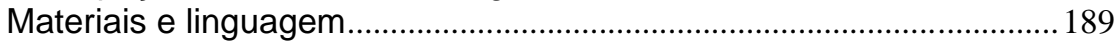

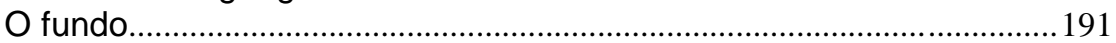

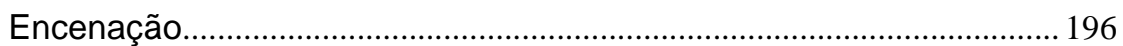

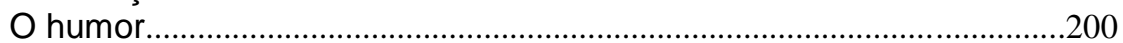

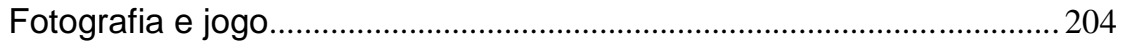

Reiterando: a família lúdica................................................................... 211

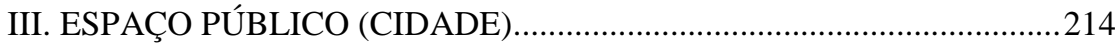

Cidade: entre natureza e artifício...........................................................216

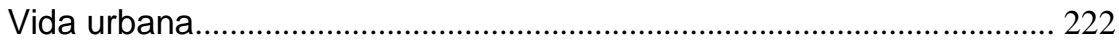

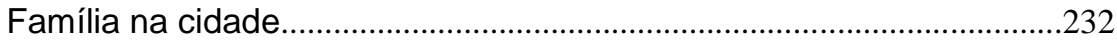

A cidade doméstica e outras cidades.......................................................228

CAPÍTULO 5. CONCLUINDO: PARA QUE SERVE A FOTOGRAFIA AMADORA?. 244

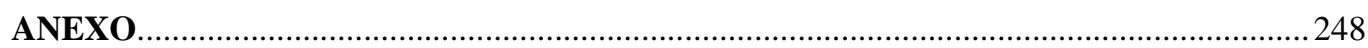

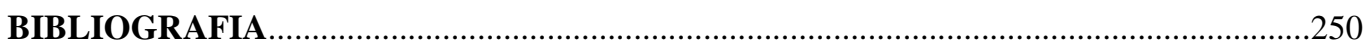




\section{INTRODUÇÃO}

A proposta deste trabalho é investigar a cultura amadora fotográfica na virada do século XIX, tendo como contexto Petrópolis e Rio de Janeiro. A linha condutora é a atuação de Alberto de Sampaio (1870-1931), advogado e fotógrafo amador que viveu entre essas duas cidades e nos deixou um eixo completo de materiais vinculados a tal problemática, que incluem suas próprias fotografias, revistas ilustradas, cartões postais, cartas pessoais, etc. Não estudamos aqui a produção fotográfica em seus conteúdos e significados, mas a utilizamos seletivamente para a análise dos componentes da cultura amadora naquele contexto, que incluem aspectos materiais, disponibilidade econômica e formas de organização social. Por isso, demos pouca relevância para questões como "representação" e trabalhamos com imagens-tipo, dentro de cada série, para atender aos nossos objetivos.

Determinamos um corte cronológico entre 1888-1914 que segue o período de maior atividade deste fotógrafo, quando se dedicou fortemente à organização de sua produção conferindo títulos, anotando datas e dados relativos aos usos de equipamentos incluindo, na maior parte das vezes, negativos de grande formato: 1888 é o início da produção e, 1914, o último ano em que foram feitos registros textuais das fotografias. Existe também unidade nas séries em termos técnicos, estéticos e temáticos. Depois disso ele continua a atividade fotográfica, mas a produção decresce sensivelmente e as imagens não têm a mesma consistência. São menos elaboradas, tem negativos em tamanho reduzido e revelam, a partir desse momento, uma abordagem mais descompromissada da fotografia. Chegaram até nós raríssimos filmes cinematográficos 
amadores, que ficaram muito limitados aos anos finais de sua vida, e, por isso, o uso dessa linguagem ficou igualmente restrito. Esse material será utilizado para a continuidade da pesquisa, mas não era essencial a este estudo.

O ano de 1914 é também uma baliza cronológica relevante, porque marca certa inflexão. Até esse período, havia circularidade de problemas no que se refere à expansão e uso da fotografia. As revistas ilustradas, por exemplo, tem características próprias, são as primeiras publicações que trazem fotografias impressas e abordam um conjunto de temáticas muito específicas voltadas, em sua maioria, para o público de perfil burguês. A prática de um dos mais importantes eixos da cultura amadora, os clubes, estará associada a essas revistas, tendo ali espaço amplo de articulação.

Portanto, estamos lidando com um conjunto de documentos que nos permitem analisar a produção amadora de fotografia como uma atividade com alta dose de interação social. Recompomos parte dos circuitos de formação desses grupos, sua atuação e o que isso é capaz de trazer para uma compreensão maior da Belle Époque no Rio de Janeiro (capital e Petrópolis).

Em tal perspectiva pareceu útil trabalhar com uma categoria que englobasse diversos componentes que estabeleciam entre os praticantes da fotografia amadora certa identidade e partilha de interesses - e, sobretudo, muito diálogo, intercâmbio e comunicação. Por certo, uma categoria analítica como o "campo artístico" proposto por Pierre Bourdieu (ou mais precisamente, o "campo de produção cultural restrita"), seria pertinente. No entanto, exigências como os princípios de estruturação e a preocupação em considerar o campo como um sistema de dominação não seriam cobertas pelas fontes de que dispúnhamos. Preferimos, assim, uma categoria próxima, mais fluida e descompromissada, de "cultura amadora", como plataforma relativamente autônoma (para fins de identificação e análise) de atributos, envolvendo os integrantes e suas 
qualificações sociais e culturais, suas práticas, seus objetivos, competências (econômica, material, técnica e outras), seus produtos, usos e funções, referenciais (critérios, normas, valores e seus veículos), suas formas de associação e interação.

Mas certos amadores se colocavam em oposição ao profissional, que também tinham suas normas e padrões próprios. O problema da distinção torna-se central e definia critérios e usos para amadores associados em clubes ou aqueles que simplesmente usavam câmeras sem ter conhecimentos técnicos sobre a atividade. Por fim, estamos tratando aqui de um nível mais amplo do que partilhar coisas comuns, é possível falar de um compromisso e de uma identidade amadora. A fim de compor esse quadro, ressaltamos o papel da cultura amadora na virada do século XIX para o campo fotográfico de forma mais ampla.

Tais questões serão desenvolvidas no trabalho que está segmentado em cinco capítulos. O primeiro, Balanço historiográfico mostramos o tratamento da temática no Brasil e no exterior, identificando lacunas, em nossos estudos, sobre a noção mais ampla da cultura amadora. No segundo capítulo, Quadros de situação, analisamos modelos, revistas e debates presentes em nosso país por um duplo viés: a respeito dos amadores associados em clubes e aqueles usuários das câmeras Kodak. No terceiro capítulo, Alberto de Sampaio, tratamos da personagem caracterizando de maneira mais ampla o contexto social de Petrópolis nessa primeira década do século XX, em relação ao Rio de Janeiro. Apontamos aqui elementos iniciais para estabelecer a especificidade da cidade serrana, assim como as tensões vividas nesse espaço social de alta representatividade para a capital do país. No quarto capítulo, A fotografia amadora de Alberto de Sampaio, tratamos das séries temáticas: a natureza, o espaço doméstico e a cidade. Identificamos nesses eixos, por um lado, evidências das discussões estéticas travadas nos clubes, por outro, relação com uso mais descompromissado da imagem, 
como era sugerido em certas revistas ilustradas. Estabelecemos também contraposição com os demais fotógrafos amadores que atuavam em nosso país, ainda que de maneira sumária devido à escassez de materiais. Por último, no quinto capítulo, Concluindo: para que serve a fotografia amadora?, fazemos as análises finais ressaltando a importância do uso comunicacional da fotografia, na produção de Alberto de Sampaio.

\section{FONTES}

Parte das fontes utilizadas provém do acervo de Alberto de Sampaio ${ }^{1}$. Temos os negativos originais, fotografias avulsas e em álbuns organizados pelo próprio fotógrafo. As fotografias, em geral, tinham grande formato com qualidade elevada de exposição e tratamento laboratorial. O primeiro passo foi, portanto, identificar as próprias imagens (locais de realização, pessoas e ações registradas) e estabelecer relação entre as séries seguindo a ordem temporal. Tratamento inicial necessário, pois encontrei essas imagens, muito bem preservadas, mas dispersas em seu armazenamento.

O fotógrafo estabeleceu sistemática própria para organizar as fotografias, que atendiam a fins de catalogação (um caderno de anotações com registros textuais técnicos e de títulos de algumas das imagens - uma lógica e reflexão sobre o material, que trataremos mais adiante). O conjunto foi fundamental para o nosso trabalho, pela riqueza de informações que acompanham algumas das fotografias produzidas por esse

\footnotetext{
${ }^{1} \mathrm{O}$ acervo, com os álbuns, cartas e documentos pessoais está com os descendentes de Alberto de Sampaio em Petrópolis. Na SOPEF (Sociedade Petropolitana de Fotografia) encontram-se os negativos, álbuns de arquivamento e equipamentos fotográficos doados por Eduardo Soares de Sampaio Filho em 1986. É importante destacar que encontrei esse material após fazer um curso de fotografia na SOPEF apenas em 1999. Depois disso iniciei o trabalho de pesquisa, ainda prematuramente, pois havia poucas informações sobre aquelas imagens. Só depois de conseguir entrar em contato com os descendentes comecei a estudar mais detalhadamente parte do acervo, em 2002, no ingresso no mestrado. O trabalho inicial de organização e identificação mais sistemática das fotografias (e de cruzamento de informações) ocorreu ao mesmo tempo em que desenvolvi a Dissertação Lentes da memória: a fotografia amadora e o Rio de Janeiro de Alberto de Sampaio (1888-1903). Demos continuidade ao trabalho, na atual pesquisa, que se utiliza da organização anteriormente feita do acervo (em relação ao uso das fontes). Porém, aqui, foi diferente o tratamento dado ao material, que pôde ser articulado com um conjunto muito mais amplo de referências daquele período.
} 
amador. Porém, reagrupamos os registros seguindo séries temáticas que atendem aos problemas analisados na pesquisa. Os conjuntos que serão tratados foram realizados, preferencialmente, no ambiente doméstico (residências, tanto de Sampaio como de familiares). Há ainda muitas cenas da natureza e, em menor quantidade, tomadas de cidades.

Alberto de Sampaio tinha também materiais de outros fotógrafos, como o conjunto de 24 fotografias da Estrada União e Indústria realizadas por Revert Henrique Klumb em 1872, para o álbum Doze horas em diligência; guia do viajante de Petrópolis a Juiz de Fora (atualmente pertencente aos arquivos do Museu Imperial de Petrópolis). Temos algumas estereoscopias, coleção de cartões postais, fotografias em formato carte de visite (sobretudo de familiares), pinturas em aquarela e um caderno de desenhos do próprio Alberto de Sampaio, mapas, além de anotações esparsas em apontamentos variados. Outro grande conjunto documentos de ordem pessoal, que integrava o acervo original, está no Instituto Histórico e Geográfico Brasileiro ${ }^{2}$. São cartas, relatórios de trabalho, diplomas, escrituras, testamentos e registros textuais de Alberto de Sampaio sobre seus familiares. Todo esse material, embora nem sempre tenha sido utilizado diretamente no trabalho, foi fundamental para termos uma compreensão mais ampla dos interesses desse amador, sendo possível reconstituir parte de sua trajetória, de seus parentes e amigos mais próximos, alguns dos quais se dedicaram também à fotografia, como veremos.

Foram examinados, nesta pesquisa, os equipamentos fotográficos remanescentes do acervo. São câmeras, negativos originais, papéis ainda não revelados, material de laboratório e uma série de objetos de uso técnico que, embora tenham sido tratados de maneira referencial, foram essenciais para começarmos a pensar nas especificidades

\footnotetext{
${ }^{2}$ Esse conjunto, que pertencia ao arquivo Alberto de Sampaio, foi doado pelos seus descendentes em 1983 ao IHGB.
} 
daquilo que era produzido para os amadores. Integravam o que denominamos a cultura amadora um saber técnico acumulado e interesses comerciais que se revelam no tipo de equipamento destinado àquele público.

Outra fonte importante para o trabalho foram as publicações impressas. O primeiro conjunto são as revistas ilustradas estrangeiras que integram o acervo deste fotógrafo. É preciso considerar que se trata de uma parcela considerável do que circulava naquele momento, e que Sampaio tinha edições completas e encadernadas dessas revistas. Apesar de estarem incompletas, porque a família doou parte do material, são indícios de que o conjunto era mais amplo. Vale observar que a presença da fotografia nessas revistas, que tinha circulação considerável no Brasil (como veremos, manter assinatura desses periódicos não era uma peculiaridade de Alberto de Sampaio), são indícios de como a temática estava difundida para o público de perfil burguês. Além disso, a presença da fotografia amadora nas mais diversas formas - em imagens, nas referências às exposições, propagandas, artigos - revelam a centralidade dessa temática para a própria revista.

Dentre as publicações analisadas no corte cronológico desta pesquisa, temos a The graphic magazine, an illustrated weekly newspaper (1869-1924), de grande formato, tendo sido a mais importante revista da Inglaterra do período vitoriano. Trazia inicialmente inúmeras ilustrações litográficas (característica que se manterá mesmo no século XX). A fotografia começa a ser referida e utilizada na década de 1890 quando, em seus artigos, encontramos muitas menções às exposições, concursos (muitos deles propostos pela própria revista para os amadores), propagandas, etc. L' Illustration (1843-1944), publicada em Paris, também de grande formato, teve sua primeira fotografia publicada em 1891. Aqui a quantidade de ilustrações era bem menor do que na The Graphic e havia certa preponderância de textos. Com esse perfil, a fotografia 
será abordada tanto em sua dimensão estética como técnica, pois ali havia seções específicas sobre processos químicos a serem usados em laboratório e equipamentos, enfim, discussões aprofundadas.

Le monde moderne, revue mensuelle illustrée (1895-1908), publicada em Paris, tinha menor formato e conferia espaço privilegiado à fotografia, sobretudo aquela associada aos clubes de amadores franceses. Havia artigos que acompanhavam as exposições, escritos por membros dos clubes, com farto uso de material ilustrado. Desta forma, as próprias imagens que eram expostas ganhavam uma segunda circulação. Lectures pour tous, revue universelle et populaire illustrée (1898-192?) seguiria a mesma linha, cobrindo, no entanto, aspectos mais amplos sobre a temática fotográfica. Ali eram organizados concursos próprios destinados aos amadores, que permitiam a entrada também de imagens com menor compromisso com o debate estético travado naquele momento. Os textos sobre fotografia revelam esse maior campo de abordagens. Foi espaço privilegiado ainda para a troca de cartões postais, utilizado pelo próprio Alberto de Sampaio, que publica anúncio numa seção destinada exclusivamente aos interessados nessas trocas.

Havia entre as publicações um número da revista dedicada exclusivamente à fotografia, a Figaro-photographe (1892), suplemento do popular jornal francês. Tratase aqui de um exemplar que teve grande tiragem no período e que cobria as principais questões ligadas à temática: aspectos históricos, avanços técnicos e o papel do amadorismo para o debate estético.

Sabemos que Alberto de Sampaio possuía outros materiais (que foram doados pelos familiares), como manuais de fotografia e revistas que não estão mais no acervo. Por isso, identificamos algumas publicações importantes que, por terem tido grande circulação no Brasil (há exemplares nas principais bibliotecas públicas do Rio de 
Janeiro e em bibliotecas remanescentes da Escola Nacional de Belas Artes e Escola Politécnica), Sampaio certamente teve acesso aos dados. Uma delas é a coleção completa da Paris-photographe, revue mensuelle illustrée de la photographie et de ses applications aux arts, aux sciences et à l'industrie (1891-1894). Essa revista de luxo tinha como colaboradores permanentes autores como Étienne-Jules Marey, os irmãos Lumière, além de membros de diversas sociedades de fotografia européias. Tratava de temas gerais ligados a fotografia, dando espaço considerável aos amadores. Há também alguns exemplares do Bulletin de l'Association Belge de Photographie (1874-1930), revista desse clube que tinha entre seus membros notáveis amadores do período, alguns deles autores de manuais. Já Amateur Work, illustrated, a practical magazine of constructive and decorative art and manual labour (1890-1895) era um revista diferente. Publicada em Londres, tinha objetivos mais amplos, pois havia preocupação com a prática amadora numa diversidade de atividades. Tinha forte conteúdo pedagógico e ensinava desde técnicas de jardinagem até como construir equipamentos fotográficos. De fato, a fotografia tinha papel relevante em cada número, havendo menções aos clubes voltados para os amadores na Inglaterra e demais países da Europa.

Quanto às revistas nacionais, não temos informação sobre a presença no acervo. Entretanto, elas foram relevantes para a análise da difusão da fotografia de caráter amador em nosso país. Pudemos estabelecer vínculo com os modelos fornecidos pelas publicações estrangeiras e, sobretudo, identificar repercussões nas cidades de Petrópolis e Rio de Janeiro.

A mais importante foi a Renascença (1904-1908), revista voltada para ao público de elite, que abordava diversas temáticas dando maior espaço para o primeiro clube de fotógrafos amadores, fundado na então capital do país, o Photo-Club do Rio de Janeiro. A Kosmos (1904-1909) também revista de alto padrão, que cobria eventos na 
capital do país e trazia artigos sobre exposições de arte, teve papel mais secundário, porém significativo, para os amadores. Ali foi publicado um texto teórico sobre questões estéticas, ligadas ao debate corrente, e algumas imagens dos amadores do clube recém-fundado. Já Leitura para todos (1905-1930), seguindo o modelo francês, era mais flexível nas abordagens e irá trazer questões mais amplas sobre fotografia, como procedimentos técnicos, concursos e artigos diversos. Analisamos também, de maneira secundária, a Revista da semana (1900-1962), Fon Fon! (1907-1958) e Careta (1908-1960), onde pudemos encontrar rico material sobre outro eixo da cultura amadora, que trata da expansão de câmeras como a Kodak, no período aqui estudado. Essencial para a contraposição que iremos estabelecer no trabalho.

Especificamente sobre Petrópolis consultamos diversos jornais como a Tribuna de Petrópolis (a partir de 1902), O mercantil (1857-1892), Gazeta de Petrópolis (18921904) e Cidade de Petrópolis (1901-1916), que pela característica dos materiais nos permitiram aferir hipóteses, estabelecer diferenças e demarcar conflitos existentes entre a cidade serrana e a capital do país. Encontramos também uma série de revistas locais, sendo a mais representativa, Verão em Petrópolis (1903/1908/1914), publicação oficial vinculada aos principais clubes de elite da cidade. Outro material importante e complementar, que nos forneceu diferentes narrativas sobre aquele espaço, foi encontrado em romances do período, de autores que trataram sobre Petrópolis.

Por último, temos uma série de depoimentos dos descendentes dos fotógrafos amadores que nos permitiram conhecer parte da trajetória daqueles que foram referenciados no trabalho. Tais dados biográficos tiveram papel fundamental para compomos o quadro das imagens produzidas por Alberto de Sampaio e identificarmos certa centralidade da problemática da cultura amadora para aquele período. 


\section{CAPÍTULO 1. BALANÇO HISTORIOGRÁFICO}

No Brasil, há ainda poucos estudos sobre fotografia amadora. Na maior parte das vezes, as análises estão relacionadas a determinados clubes de fotografia e tratam do funcionamento das instituições, seus personagens principais, a contaminação das imagens produzidas em outros meios impressos, etc. Privilegia-se, nesta perspectiva, a mediação entre fotografia e o campo das artes plásticas, trazendo-se a tona os amadores ditos "eruditos", que dominavam completamente as técnicas empregadas. Mas há ainda os amadores que começavam a usar as câmeras de fácil manuseio, com suas imagens sem pretensões estilísticas, tão características do ambiente fotoclubístico. Estes, no entanto, foram tratados de maneira secundária.

Há dois trabalhos mais recentes realizados a partir de coleções e que se diferenciam dos demais estudos realizados até então, por tratarem de acervos individuais. A tese de doutorado de Suzana Barreto Ribeiro (2003), Percursos do olhar na fotografia profissional e amadora de Campinas (1900-1915), investiga a produção de imagens urbanas de Austero Penteado (1849-?), que era herdeiro de fazendas de café nessa cidade e fotógrafo amador. A autora estabelece comparações com a produção que circulava em cartões postais, almanaques e álbuns publicados por instituições ligadas ao poder público. Analisa a dicotomia profissional/amador, estabelecendo algumas formas de mediação (ensino) e, outras, de diferenciação, como o afastamento do amador das representações urbanas, contrário à visão progressista encontrada na produção profissional. Ressalta também que a apropriação dessa estética internacionalista se desenvolvia no trabalho de Penteado de maneira específica. Tal questão é relevante 
porque evidencia ser preciso tratar do problema da assimilação no movimento "pictorialista", que se revelaria em Penteado numa maior aproximação das pinturas de caráter regionalista.

O segundo trabalho é $O$ olhar fotográfico de Francisco Brandão, de Eduardo Alves Covas (2005), que analisa, na dissertação de mestrado, as imagens produzidas por este farmacêutico (1873- 1952) de origem portuguesa e fotógrafo amador, que se estabeleceu na cidade de Piracaia (SP). Aqui, segundo o autor, há algumas aproximações com os registros de Austero Penteado no que se refere a não predileção pelos sinais de transformação urbana. Aponta também diferenças, como a importância das fotografias de família e menor preocupação estética, relativa aos cânones oriundos da pintura e debates dos pictorialistas. $\mathrm{O}$ autor privilegia a biografia do fotógrafo para a compreensão do acervo, apresentando alguns elementos sobre o uso da imagem de maneira mais descompromissada. Um problema relevante e não referenciado nos demais estudos que incluem a temática da fotografia amadora em nosso país.

Mas a figura do amador é introduzida no âmbito acadêmico a partir da década de 1980, em trabalhos gerais sobre história da fotografia. Um trabalho reconhecidamente pioneiro foi Origens e expansão da fotografia no Brasil, século XIX de Boris Kossoy (1980). O autor mapeia quais os principais fotógrafos que percorreram e atuaram em nosso território, identifica os procedimentos e técnicas utilizadas e ainda relaciona com o que ocorria no exterior. Nesse conjunto panorâmico, o desenvolvimento da atividade amadora é apontado como um fator crucial para a difusão da fotografia naquele período.

É preciso apontar a dificuldade de acesso às produções que não haviam alcançado o circuito comercial. Por isso, aqueles amadores vinculados a estética difundida pelos clubes, fundados no início do século XX, são mencionados, e os usuários das câmeras Kodak entram como um dado genérico. Temos, porém, pela 
primeira vez assinaladas as principais diferenças no circuito, já com localização geográfica em nosso país: de um lado os amadores que atuaram no Rio de Janeiro, Rio Grande do Sul e São Paulo em sociedades e, de outro, os "batedores de chapas" da Kodak.

Posteriormente, na tese de doutorado de Ana Maria Mauad (1990), Sob o signo da imagem: a produção da fotografia e o controle dos códigos de representação social da classe dominante, no Rio de Janeiro, na primeira metade do século XX, a fotografia amadora ganharia maior tratamento, integrando as fontes documentais da pesquisa. Neste primeiro trabalho a utilizar fotografias de família, com propostas metodológicas análise histórico-semiótica - a autora estabelece como parâmetro para o estudo do acervo de Mariana Jabour Mauad (que inclui fotos tiradas por profissionais e pela própria família), as imagens publicadas em duas revistas ilustradas do período, a Careta (1908-1950) e O Cruzeiro (1928-1950), seguindo determinados intervalos de tempo. Além de utilizar de forma inédita um acervo familiar, Mauad também adiciona novos dados a respeito da difusão das câmeras Kodak no Rio de Janeiro, dando importância ao espaço da publicidade. Nos remete, ainda, à presença do Photo-Club do Rio de Janeiro (embora aponte a falta de informações sobre o funcionamento da associação) e ao posterior desenvolvimento como Photo Club Brasileiro, ressaltando a participação dos amadores deste clube na revista O Cruzeiro, em fins da década de 1920. Mas aqui, como dissemos, o interesse é sobre a fotografia de "família", por isso, privilegia-se, no acervo, o material produzido também por profissionais.

O problema da mediação entre os amadores que integravam sociedades e as revistas ilustradas foi muito bem abordado no artigo de Helouise Costa (1991) “Pictorialismo e imprensa: o caso da revista O Cruzeiro (1928-1932)". A autora analisa as diversas formas de participação dos amadores do Photo Club Brasileiro neste 
periódico através da publicação de imagens produzidas por membros do clube - desde fotos artísticas até instantâneos do Rio de Janeiro de forma mais próxima das imagens divulgadas na imprensa ilustrada da época - e ainda na organização de concursos destinados aos amadores. Aqui, Costa mostra que os pictorialistas, ao contrário do que lhes é comumente imputado como estando presos às regras acadêmicas da pintura, tiveram, no caso brasileiro, participação no desenvolvimento da fotografia de caráter moderno. Esta revista, que também fora estudada em sua tese de doutorado, Aprenda a ver as coisas. Fotojornalismo e modernidade na revista O Cruzeiro, de 1992, é um exemplo importante para mostrar o quanto essas fronteiras eram permeáveis num momento em que os mais preparados para exercer a fotografia faziam parte do PhotoClub, pois não havia escolas e os próprios profissionais estavam circunscritos aos padrões oriundos da retratística e das imagens paisagísticas do século XIX.

Outro estudo importante é Arte e fotografia: o movimento pictorialista no Brasil de Maria Teresa Bandeira de Mello (1998). Nesse caso, foi analisada a trajetória do Photo Club Brasileiro na década de 1920 e há poucas informações sobre o seu antecessor, o Photo-Club do Rio de Janeiro (inaugurado no início do século XX). A autora centra-se na discussão sobre a fotografia de caráter artístico e menciona elementos introduzidos no campo fotográfico sob a influência dos pictorialistas. Utilizando bibliografia internacional, faz referência aos problemas centrais para os debates estéticos daqueles grupos, como o papel da "interpretação" e da expressão subjetiva. A fotografia desses amadores, que intervinham diretamente sobre o suporte da imagem, servia também, como aponta Mello, para que os atributos qualificativos da fotografia documental como registro do "real" fossem colocados em questão. Os pictorialistas abrem espaço, sob essa perspectiva, para o nascimento da fotografia moderna porque não ficaram restritos à simples imitação da pintura (o pictorialismo 
anedótico, segundo a autora), havendo uma vertente em que se estabeleceu um profícuo debate sobre a "forma" e, consequentemente, de questões próprias do campo fotográfico.

Miriam Moreira Leite (1993) nos traz outras contribuições em Retratos de Família: leitura da fotografia histórica e artigos como "Fotografia e História" (1988), utilizando produções amadoras e profissionais. Fugindo do problema estético clubístico, a autora analisa a fotografia como objeto relevante que permite a compreensão da instituição familiar. Destaca problemas como o papel da fotografia como integradora dos membros da família, a função de continuidade (estabelece ordenação temporal, na qual o indivíduo se insere), e aponta que essas imagens podem ser consideradas como um sinal de prosperidade para o grupo (no caso dos imigrantes).

Há também referências gerais aos amadores e à tecnologia produzida para esse segmento em outros trabalhos. Solange Ferraz de Lima (1991), em "O circuito social da fotografia: estudo de caso - II”, centra sua análise na São Paulo da segunda metade do século XIX. A autora faz importantes observações sobre a atividade amadorística em relação à expansão da Kodak e ao desenvolvimento dos clubes, inclusive, menciona um Photo Club, fundado em 1900 na capital paulista. A questão principal é como o amador, inserido num quadro de expansão de tecnologias, foi um agente de reorganização da própria atividade profissional. Como diminuiu a demanda por retratos, os estúdios precisavam diversificar os serviços oferecidos para se manterem economicamente. Nesse contexto, há incremento na comercialização de produtos nos ateliês (álbuns, equipamentos, material para laboratório, etc), ensino da atividade e valorização da produção de vistas (ganham espaço nas próprias exposições do Photo Club).

Em “Descobrindo a fotografia nos manuais: América (1840-1880)" de Ricardo Mendes (1991), há algumas menções ao papel dos amadores no início da difusão da 
fotografia. No estudo centrado em material produzido nos EUA, o autor ressalta também a importância desses fotógrafos para a pesquisa, produção e difusão de novos materiais ao longo do século XIX.

Em Poses e trejeitos: a fotografia e as exposições na era do espetáculo - 18391889 de Maria Inez Turazzi (1995). A autora identifica o amadorismo em relação às mudanças de ordem tecnológica do período, vinculando-o ao aparecimento da indústria do turismo. Lembra ainda que a fotografia produzida por amadores, em muitos casos, torna-se um souvenir, objeto que circula e integra o mercado consumidor.

Já Flora Sussekind (1987) em Cinematógrafo das letras: Literatura, técnica e modernização no Brasil nos oferece dados sobre a difusão da Kodak em vários espaços. Com o objetivo de analisar as transformações ocorridas no âmbito literário, em virtude da disseminação social de equipamentos como a câmera fotográfica, o cinematógrafo e o fonógrafo no início do século XX, a autora foi a primeira a destacar as repercussões mais amplas do equipamento, inicialmente destinado aos amadores. Menciona a participação da Kodak em algumas colunas nas revistas ilustradas e as reapropriações metafóricas do termo derivado do instantâneo. Mas como foge totalmente aos objetivos do trabalho, não foi investigada a relação da Kodak com o consumo e produção de imagens amadoras assim como seus possíveis desdobramentos no campo fotográfico.

Nos EUA e Europa, diferentemente do Brasil, a categoria do fotógrafo amador foi amplamente contemplada, seja em alusão à circulação das imagens no espaço doméstico, seja na menção a clubes. Um dos primeiros trabalhos - e também dos mais relevantes - tendo como eixo o grupo familiar, foi realizado por Pierre Bourdieu (1965) em Un Art Moyen: essai sur les usages sociaux de la photographie. O autor observa as regularidades, como certos indivíduos são fotografados em certas ocasiões, e que a fotografia de família, ao contrário do que é comumente referida, é altamente 
convencional e segue normas estritas que se expressam na escolha das temáticas, comportamentos e aspectos formais. Ressalta ainda a "função familiar" da fotografia para a integração do grupo (está associada aos momentos significativos) e como as normas, que tem representatividade inicial para a família, ultrapassam esse contexto, integrando a própria definição social desse tipo de imagem. Isso se evidenciará na segunda parte escrita por Robert Castel e Dominique Schnapper que trata da estética dos fotoclubes, cujos membros estarão em busca de uma segunda legitimação. Ali há o desejo de apropriação de modelos culturais (aspirações estéticas superiores) como uma forma de distinção social. Essas questões foram utilizadas também num artigo publicado, simultaneamente a Un Art Moyen, Le paysan et la photographie, de Pierre e Marie-Claire Bourdieu (1965). Os autores analisam a produção fotográfica de um grupo de camponeses em Béarn, na França, ressaltando novamente o problema dos ritos familiares, que são selecionados para serem registrados, os quais evidenciam a dinâmica e os papéis sociais do grupo analisado. No caso, não é usado o termo fotografia amadora, até porque foram consideradas imagens tiradas por profissionais. Mas trata-se de um estudo que já considera a produção fora dos grandes centros e a fotografia aparece como um instrumento que permite confrontar esferas sociais distintas.

Outro trabalho pioneiro foi Snapshot versions of life de Richard Chalfen (1987). Com forte preocupação metodológica o estudo se direciona a produção amadora associada à Kodak (em parte pela importância do equipamento nos EUA). Foi o primeiro a empregar a noção de "cultura" nesse contexto - especificamente Kodak Culture - entendendo as fotografias como uma forma de comunicação simbólica. Apesar de serem questões já tratadas noutros campos, ele aplica tais referências em imagens comuns que, de fato, se distanciam das altas pretensões estéticas existentes em clubes. Inverte a posição, analisando as fotografias que ficam armazenadas em álbuns 
familiares como um vetor que reflete e, ao mesmo tempo, promove diferentes olhares sobre a vida social. Ressalta também o problema da seleção (exclusão de conflitos, tensões vividas pelo grupo) e que as fotografias nos fornecem apenas versões da "realidade", por meio das quais as pessoas se organizam socialmente.

A partir desses trabalhos identificamos três eixos principais que norteiam as abordagens sobre o tema: o primeiro está relacionado com a problemática da fotografia de família, que de fato, foi o eixo de análise no qual se originou os estudos no campo; o segundo atribui ênfase à formação de sociedades e clubes; numa terceira vertente os estudos estão focados na influência das imagens produzidas pelos amadores em outros setores da vida social.

Um trabalho significativo desse primeiro eixo é a coletânea The familial gaze de Mariane Hirsch (1999) em que artistas, historiadores e antropólogos analisam imagens contemporâneas e antigas, numa abordagem interdisciplinar. Ressalta-se, aqui, as raízes culturais dos modelos representacionais, a relação do álbum de família com a memória coletiva e as diversas mediações entre as esferas pública e privada. Para a autora, a fotografia serve como "instrumento" que evidencia a ideologia do grupo familiar e, ao mesmo tempo, pode servir como meio de contestação e resistência. Já Patricia Holland (1998) em "Sweet it is to scan.., personal photographs and popular photography" aponta a relação entre a expansão da noção de família no século XX com o consumo e produção de fotografias. O estudo centra-se no caso específico da Kodak que, em suas propagandas em revistas, valorizavam o sentido de memória, sobretudo a partir da Primeira Guerra Mundial.

O segundo eixo de trabalhos se dedica ao estudo de associações. Trazem a perspectiva estética de amadores que se contrapunham muitas vezes aos profissionais. Como as imagens tinham circulação pública, questões ligadas ao ambiente doméstico 
eram praticamente inexistentes. Nesse âmbito, Grace Seiberling (1986) em Amateur photography and mid-victorian imagination traça um rico quadro da situação da Inglaterra na década de 1850. Apesar de ser uma situação específica, a autora destaca alguns componentes, ali evidenciados, que iriam ser cruciais para o desenvolvimento da fotografia amadora no século XIX: circulação de materiais e troca de informações. Aqueles amadores tiveram papel precursor, sendo fundadores de clubes voltados para a prática da fotografia. Eram membros da aristocracia que tinham alta cultura, dominando diversos campos do saber. Há também preocupação em discutir historicamente o conceito de amador, que será considerado em capítulos seguintes de nossa pesquisa.

$\mathrm{Na}$ França, o desenvolvimento da fotografia amadora foi semelhante ao que ocorreu na Inglaterra, como observamos em trabalhos que abordam o mesmo período. De acordo com Abigail Solomon-Godeau (2002), no artigo "Calotypomanie", os amadores na década de 1850 se tornariam num protótipo para os discursos sobre fotografia e arte, que ressurgiram em fins do século XIX. Trata-se daqueles que integravam a Royal Photographic Society e a Société Française de Photographie - os gentlemen que mantinham distância da fotografia comercial. A autora ressalta ainda que os critérios de utilização daqueles que operavam os equipamentos devem ser privilegiados em detrimento de meros referenciais a valores estéticos. Com isso, valoriza o papel dos que estavam fora do circuito comercial da atividade.

Nessa mesma perspectiva André Gunthert (2002) em "L'instituition du photographique" se refere aos "amateurs-experts", que estavam presentes em instituições como a Société Héliographique. Mas na passagem do modelo de sociedades de savants e especialistas para o formato de clubes, outras mudanças ocorreram, conforme aponta Michel Poivert (2001) em "La photographie française en 1900. L'échec du pictorialisme”. Nesse momento, introduz-se a noção de excursão fotográfica 
e surgem clubes menos preocupados com a questão estética. Mas em face de tantas mudanças, inclusive de ordem tecnológica, havia certo conservadorismo nesses grupos. Eles recuperavam técnicas do passado e eram anacrônicos, pois, ao mesmo tempo em que promoviam a fotografia, rejeitavam suas propriedades eminentemente técnicas.

A situação dessas discussões estéticas no âmbito de clubes nos EUA foi muito bem analisada em Between amateur and aesthete de Paul Spencer Sternberger (2001). Sua preocupação é mostrar o quanto o desenvolvimento do que ficou conhecido como pictorialismo, naquele país, foi controverso, tendo várias correntes que se contrapunham. Aqui o amador não apenas compartilhava informações, mas constituía um acirrado espaço de conflito e disputa. As formas de interação e circulação social permaneciam, com as publicações e exposições próprias, importantes para consolidar a idéia de que a fotografia era uma expressão artística. O autor identifica ainda no debate sobre estética - que fornecia bases para a crítica ao realismo fotográfico - $\mathrm{o}$ aparecimento da noção de imagem subjetiva herdada de autores tão díspares como Jonh Ruskin e Eugène Véron.

Num terceiro eixo de trabalhos encontram-se abordagens que privilegiam as transformações na vida social, ocorridas em função da expansão da fotografia amadora e suas mediações institucionais. Cristan Joschke (2004) em « Aux origines des usages sociaux de la photographie. La photographie amateur en Allemagne entre 1890 et 1910”, propõe que, entre a divisão normalmente imputada aos amadores, de um lado, os que praticavam a fotografia artística vinculados a clubes e, de outro, os que utilizavam as câmeras Kodak estando somente associados ao espaço doméstico, havia uma situação intermediária: trata-se dos amadores que participaram na Alemanha e mesmo na Inglaterra na formação das primeiras coleções do patrimônio arquitetônico e de registros de caráter etnográfico nos museus. Identificando as associações entre as sociedades de 
amadores e as instituições museológicas, Joschke (2005) desenvolve os mesmos problemas na tese Les yeux de la nation: photographie amateur et sociéte dans l'allemagne de Gullaume II. O autor ressalta que na Alemanha pós unificação, a prática amadora era um meio de construir e participar de uma cultura comum e os registros do território, realizados por esses grupos, auxiliaram a construção de identidades regionais.

Tom Gunning (2001) ressalta outras intermediações em "New thresholds of vision: instantaneous photography and the early cinema of Lumière". O autor destaca a existência de uma "cultura amadora", altamente representativa em fins do século XIX, que se constituía de maneira independente por meio de espaços sociais como clubes, publicações especializadas e exposições de fotografia. Demonstra também que elementos dessa cultura estiveram presentes na própria invenção do cinema, destacando o papel da representação do corpo em movimento neste circuito.

Meir Widegoder (2003) analisa em "Paul Strand's New York portraits, private eye - public space" o surgimento do tema "invasão de privacidade" com a popularização das câmeras detetive chamadas de "hand cameras", entre as quais a Kodak, na cidade de Nova York entre 1885-1916. Tomando por base os retratos de Paul Strand (produzidos de forma quase camuflada), a autora identifica de que maneira essa mudança de hábito, suportada por invenções tecnológicas, modificaram o comportamento em público. Utiliza manuais de etiqueta, revistas de fotografia e relatos em jornais de pessoas que reclamavam sobre a sua "privacidade". Tal problema alcança outras esferas, contamina o próprio espaço da fotografia profissional documental que via nas populações de baixa renda e anônimas um verdadeiro retrato da metrópole.

Por último, dentro desse conjunto, Nancy West (2000) em Kodak and lens of nostalgia analisa especificamente as propagandas da Kodak, desde o lançamento do equipamento até a década de 1920. Para a autora, as propagandas tiveram papel 
pedagógico, pois ensinaram, de maneira simplificada, quais temas que mereciam ser registrados e que a fotografia desempenharia papel específico para o núcleo familiar. Analisa as imagens (gestos, objetos e espaços) e os textos que acompanhavam as propagandas. Identifica uma mudança na prática fotográfica, em que a Kodak teve contribuição: de uma atividade como simples diversão a um uso com memória. A noção de lazer, problemas de gênero e aspectos materiais (indumentária, brinquedos infantis, etc) que foram mobilizados nos reclames constituíram-se, ao mesmo tempo, como agentes de transformação da vida social.

Cumpre finalmente lembrar na Europa e EUA, ao contrário do Brasil, há material, sabe-se onde estão as coleções e como foram organizadas, por isso o quadro é totalmente diverso. Grande parte dos acervos está em museus de antropologia (sobretudo no caso europeu), lugares em que diversos autores fizeram suas pesquisas. Nesse contexto mais favorável, já está sedimentada toda uma área em que o fenômeno do amadorismo é privilegiado para a história da fotografia. Valoriza-se a figura do amador, que estava equiparado aos profissionais, e, do mesmo modo, aqueles que utilizavam câmeras portáteis. Alguns elementos dessas questões estarão presentes nesta pesquisa.

Em nosso país, a carência, em parte, se deve pela dificuldade de acesso a coleções. Não há levantamento nas instituições e a documentação é dispersa, pertencendo, em muitos casos, a acervos privados. Por isso, o problema da "cultura amadora" na virada do século XIX, não foi ainda estudado. Porém, apesar de existirem relativamente poucos trabalhos que tratam a fotografia amadora, ora como objeto central, ora em simples referências a aspectos gerais, todos os que foram aqui mencionados são estudos de qualidade e relevância. 


\section{CAPÍTULO 2. QUADROS DE SITUAÇÃO}

Para entendermos os espaços de organização e funcionamento de uma cultura amadora no Brasil, no período analisado na pesquisa, é necessário identificar elementos gerais que já integravam a atividade dos profissionais em fins do século XIX. Isso porque havia um circuito sedimentado com locais de exposição (Nacionais e de Bellas Artes) e, ainda, de difusão da fotografia em instituições de ensino. Porém, o contexto não era favorável à fotografia amadora. Faltava principalmente base institucional com clubes independentes que servissem para troca de informações, ensino, exposições, etc.

Esse quadro geral é importante para compreendermos a importância do PhotoClub do Rio de Janeiro, fundado em 1904: primeiro clube que surgiu na capital do país e que era liderado por amadores. O grupo introduziu diversas inovações. Utilizou, por exemplo, de maneira inédita, revistas ilustradas nacionais para dar cobertura a três exposições, num período em que havia raríssimos manuais técnicos publicados em português.

Os objetivos eram mais amplos, pois eles se colocavam como mediadores diretos do que ocorria no Exterior, sobretudo no Photo-Club de Paris. É nesse mesmo momento, também, que o Rio de Janeiro passava por grandes reformas urbanas. Mas o clube era lugar privilegiado de debates e preocupações de ordem estética, integrantes do movimento clubístico internacional. Apesar de ficarem alheios às questões ligadas ao espaço urbano - como era próprio desse tipo de associação - transformaram a figura do amador, em nosso país, no eixo condutor de discussões e de inovações para o campo fotográfico de maneira mais ampla. 


\section{O circuito das exposições}

Trataremos inicialmente do circuito público fotográfico, no Brasil do século XIX, em que predominava vínculo com instituições oficiais, associadas diretamente às esferas do poder, com participação majoritária dos profissionais. A fotografia, como demonstrou Maria Inez Turazzi (1995), estava presente nas exposições de caráter regional, que serviam como uma primeira amostra do material que seria escolhido para ser enviado às exposições universais. E ainda integrava as exposições organizadas pela Academia Imperial de Bellas Artes, no Rio de Janeiro, onde a participação da fotografia foi bastante relevante. Como a autora destaca, desde as primeiras mostras organizadas por essa instituição já havia exibições de fotografia. Mas estas se espalhavam inicialmente por seções gerais, de arquitetura, enfim, eram um elemento a mais dentro de um conjunto formado por outros materiais ${ }^{3}$. Somente em 1879 é que foi criada a seção de "Photographia", que iria perdurar ainda nas duas últimas exposições organizadas no período imperial $-1882^{4}$ e 1884 . Tais espaços foram fundamentais para demarcar simbolicamente a importância dos profissionais que ali expunham. Em alguns casos, havia também, nas publicações que cobriam os eventos, discussões teóricas e de caráter técnico.

Com o fim do Império a instituição passa a ser chamada de Escola Nacional de Bellas Artes e decresce a importância da fotografia naquele espaço. Depois disso ainda encontramos no catálogo da exposição de 1890, a participação de fotografias na seção de "Indústria Decorada", exibidas junto a porcelanas e aparelhos de relojoaria. Ora, esse retrocesso é significativo, pois as demais exposições cobririam apenas às áreas de

\footnotetext{
${ }^{3}$ Como Turazzi (1995: 112) destaca, a introdução da fotografia começou já em 1842 quando ainda foi disposta no próprio gabinete do diretor da escola. Depois, em 1859, é introduzida na seção dos "artefatos da indústria e aplicação das bellas artes". Nos anos seguintes $(1860,1862,1864-68,1870,1872,1875)$ se espalha por várias áreas como de "arquitetura" e "seção geral".

${ }^{4}$ A "Exposição Nacional de Bellas Artes" de 1882 ocorreu no Liceu de Artes e Ofícios no Rio de Janeiro. Havia também a seção "Photographia", conforme aparece na dissertação de Bielinski (2003:118).
} 
estudo da escola. No período republicano a fotografia, então, foi excluída daquelas mostras anuais.

Porém, nas exposições ligadas ao governo, em que as imagens teriam papel de representar oficialmente o país também para a população local, permaneceram as "seções" de fotografia. Por isso, importantes profissionais do período tiveram seus trabalhos divulgados em 1900, na Exposição Artístico-Industrial Fluminense (organizada no Liceu de Artes e Ofícios), período de comemoração do quarto centenário do descobrimento do Brasil.

\section{Propostas pedagógicas}

Havia toda uma discussão já sedimentada nos países europeus, a respeito da fotografia dever integrar o sistema de ensino, da mesma forma que ocorria com as cadeiras de desenho. O impacto dessas idéias, no entanto, foi bastante restrito no Brasil, pois como as condições locais não eram favoráveis à formação de espaços autônomos para a fotografia, era de esperar que esse tipo de proposição encontrasse ainda mais restrições.

De fato, apenas as escolas politécnicas tinham a fotografia como parte integrante da disciplina de "Physica Industrial", que era oferecida em cursos básicos e, de forma mais avançada, para os que tiravam o título de engenheiro de Artes e Manufaturas. Com a reforma de 1874, que criou a Escola Politécnica do Rio de Janeiro ${ }^{5}$, foram introduzidas essas modificações curriculares (Turazzi, 1997: 155). O modelo se

\footnotetext{
${ }^{5}$ A Escola Politécnica teve origem na reforma de 1874 numa separação da Escola Central que formavam engenheiros militares. As mudanças empreendidas tinham como modelo a École Polytechnique de Paris. Novos cursos foram implementados, visando à formação num âmbito científico e abrangiam a área de Ciências Físicas e Naturais, Ciências Físicas e Matemáticas, Engenharia Civil, Geográfica, de Minas e de Artes e Manufaturas (Telles, 1984: 467).
} 
difundiu e na década de 1890, momento em que a Escola Politécnica de São Paulo adotou o mesmo currículo do Rio de Janeiro.

O debate mais amplo, sobre a fotografia como elemento de formação, teve também repercussões em nosso país. Um material significativo pertencia a Rui Barbosa: era o manual La photographie et la chimie de la lumiére, de Herman Wilheim Vogel, publicado em $1876^{6}$. Num dos capítulos "La photographie comme objet d'enseignement dans les écoles industrielles et les écoles artistiques" há uma longa discussão sobre questões pedagógicas. O autor, professor da Escola Industrial de Berlim, destaca a importância da fotografia em cursos de belas artes e de engenharia, sem ter a preocupação na formação de profissionais do ramo. Nesse mesmo tópico há várias partes sublinhadas em vermelho pelo próprio Rui Barbosa. Vejamos a seguir um desses trechos:

«L'introduction de la photographie dans les écoles est d'autant plus facile que, comme on l'a déjà fait observer, cette étude exige fort peu de temps. Le dessin en absorbe bien davantage pour donner des résultats qui souvent sont relativement bien faibles. Quatre heures d'exercice par semaine, pendant un semestre, suffisent à pousser l'instruction photographiques des jeunes gens assez loin pour leur permettre de se tirer plus tard d'embarras, lors même qu'au début, ils n'auraient aucune connaissance chimique.

Cet enseignement ne devra pas uniquement préoccuper les écoles supérieures d'industrie et de beaux-arts ; les écoles scientifiques doivent également tourner leur attention de ce côté, depuis que la photographie est devenue un important instrument d'observation et qu'elle rend surtout aux sciences naturelles des services d'une importance incalculable » (Vogel, $1876: 218$ ).

A fotografia entendida como um instrumento de observação, que junto ao desenho auxiliava os trabalhos em ciências naturais, era um elemento de destaque para as proposições de Voguel e, certamente, chamou atenção de Rui Barbosa. Mas afinal, para que ele teria grifado esse trecho? Essa teria sido a bibliografia que serviu para

\footnotetext{
${ }^{6}$ Há exemplares desse manual na Biblioteca Nacional e no Real Gabinete Português de Leitura. Na biblioteca da antiga Escola Politécnica de São Paulo existe um exemplar com tradução em inglês: The chemistry of light and photography.
} 
preparar os pareceres, que não tiveram êxito, sobre a reforma de ensino do nível básico ao superior, escritos entre 1882 e 1883 , no período em que foi deputado geral ${ }^{7}$ ? Ou ainda foi material utilizado para o discurso, "O desenho e a arte industrial", em que defendia a introdução de disciplinas relacionadas às artes industriais em todos os níveis escolares, proferido no Liceu de Artes em Ofícios do Rio de Janeiro em 1884? Essas são questões a que não podemos responder. No entanto, o fato relevante, no manual grifado e no discurso de Rui Barbosa, é que já tinha chegado a nosso país (tendo repercussões) o debate sobre o papel do ensino da fotografia para formar um novo tipo de sujeito para a sociedade.

É possível identificar, ainda, nas reformas de ensino no século XIX - nunca totalmente implementadas - sugestões de que a fotografia poderia estar incluía. Não temos os dados detalhados dos tópicos abordados nas matérias propostas, nem mesmo nos decretos publicados, porém, pelo programa, observamos semelhanças com a "Physica Industrial", oferecida nos cursos de engenharia da Escola Politécnica.

A primeira reforma ocorreu em abril de 1879, quando foram criados os três níveis do ensino brasileiro: escola primária, de primeiro e segundo grau. Nesse último estágio seria introduzida a disciplina "Noções de physica, chimica e historia natural, com explicação de suas principaes apllicações a industria e aos usos da vida”. Mas essa disciplina, como outras propostas neste projeto, ficou no papel. Como aparece no Livro do Centenário (1900: 18), "para que esse progamma pudesse ter execução, era preciso: $1^{\circ}$, ter mestres capazes; $2^{\circ}$ possuir casas apropriadas e o apparelho necessário para o ensino. Nem uma nem outra cousa havia”.

\footnotetext{
${ }^{7}$ Rui Barbosa (1849-1923) foi advogado, político, jornalista e diplomata. Teve atuação extensa no Império e na República Velha. Quando eleito deputado geral entre 1879-84, atuou na reforma eleitoral que promulgou a Lei Saraiva (1881) estabelecendo eleições diretas. A mudança provocada pela lei fora ampla, embora ainda mantivesse o voto censitário e se excluíssem os analfabetos do processo. Em 1882, no seu segundo mandato, apresenta projeto na Câmara para realização de reformas no sistema de ensino brasileiro. Escreve então dois pareceres: Reforma do Ensino Secundário e Superior (1882) e a Reforma do Ensino Primário e várias Instituições Complementares da Instrução Pública (1883) (Gonçalves, 2000; Barbosa, 1942).
} 
Em 1889-1890, em outra reforma de ensino realizada após a proclamação da República, há indicação da disciplina "Elementos de sciencias physicas e historia natural applicáveis às industrias". Trata-se da mesma matéria de 1879, com diferente nomeação. Mas também nesse caso tudo ficou apenas no projeto ${ }^{8}$.

A partir desses dados podemos destacar uma questão central: as referências ao ensino técnico, que incluíam a fotografia, não se pautavam apenas na idéia da formação intelectual como "instrumento de observação". Havia o problema muito discutido na época sobre a "indústria nacional" que conduziu debates sobre como seria possível formar a base para o futuro desenvolvimento do país. Elementos dessa proposta podem ser identificados no discurso de Rui Barbosa (1982: 38) proferido no Liceu de Artes e Ofícios em 1882, instituição que, para ele, era um modelo de “educação industrial” num país ainda agrícola.

Era necessário então "educar esteticamente as massas", daí a preponderância do ensino do desenho, fundamental para a formação intelectual da população. Rui Barbosa, porém, considerava em seu discurso que "as belas artes e as artes industriais são duas naturezas homogêneas e homorgânicas" e, portanto, deveriam estar integradas no sistema de ensino; era preciso assim "criar a educação industrial” (Ibid.: 20, 22, 30). Investir em instrução no campo artístico teria conseqüências em dois eixos principais: iria favorecer o consumo dos produtos à medida que ampliasse o número daqueles que tinham conhecimento e acesso às inovações e também expandiria os meios de obtenção de reconhecimento do próprio artista. Isso se tornava imprescindível, pois, como o próprio Rui Barbosa reconhecia, "as obras notáveis já não apelam para o publico,

\footnotetext{
${ }^{8}$ As referências à essas reformas estão no Livro do centenário (1500-1900) organizado pela "Associação do quarto centenário do descobrimento do Brasil" em 1900.

${ }^{9} \mathrm{O}$ termo "indústria nacional" tinha significados diferentes, podendo ser referido às produções manufatureiras ou atividades industriais. Estava presente e discursos de pessoas como Bethencourt da Silva, idealizador e diretor por muitos anos do Liceu de Artes e Ofícios, ou Getúlio das Neves autor do artigo "A industria nacional" na Revista Brasileira em 1895.
} 
unicamente pela tela, pelo desenho, ou pela escultura original, senão pelos infinitos modos de reprodução industrial" (Ibid.: 38; apud Bielinski, 2003: 159). Dentre eles havia a gravura, a litografia e também a "photographia".

O discurso, no entanto, teve impacto bastante restrito, muito mais no próprio Liceu que no início do século seguinte incluiria a formação de "Photographo" 10 entre os cursos oferecidos pela instituição. A duração era de três anos e tinha disciplinas que incluíam física, química e desenho, ministradas no Rio de Janeiro ${ }^{11}$.

\section{Os modelos: manuais, jornais e revistas estrangeiras}

A fotografia estava restrita a poucos espaços institucionais, não havendo formação específica que pudesse ser oferecida aos amadores. Nesse contexto, as publicações que tratavam da temática, majoritariamente estrangeiras, teriam papel fundamental na formação de novos grupos. É sabido que esses materiais circulavam em bibliotecas públicas e naquelas que estavam nos cursos superiores de engenharia e belas artes. Podiam também ser encontradas nas principais livrarias da cidade. Apesar de haver enorme diversidade é possível dividir tais publicações em três eixos principais: manuais de fotografia; revistas e jornais de sociedades e clubes; e, por último, as revistas ilustradas.

\footnotetext{
${ }^{10}$ Dentre as 52 profissões, o aluno podia se formar em "Lithographo" e também "Photographo", ambos com duração de três anos, e estava segmentado em duas partes: a primeira formada pelas "Sciencias" congregava todas as disciplinas ligadas à técnica composta por aulas obrigatórias de Geometria, Trigonometria e, ainda, Physica e Chymica Applicadas que deveriam ser freqüentadas somente naquilo que interessasse a profissão. Na segunda parte, composta pelas matérias artísticas havia Desenho de Figura, Desenho Geométrico, Desenho de Ornatos, Architetura Civil, Escultura de Ornatos e Pintura, e Estudos a Tempera. Bielinski (2003: 150) apresenta o organograma do curso oferecido no Rio de Janeiro. ${ }^{11}$ O Liceu de Artes e Ofícios de Petrópolis funcionou entre 1899 e 1916. Nos anos 1920 foi novamente reaberto tendo muito mais cursos em sua grade curricular, dentre eles o de "Photographo". É provável que tenha sido nessa mesma década que o curso foi também oferecido no Rio de Janeiro. Temos duas cópias do organograma dos cursos de ambas as instituições, mas sem data. Uma delas citada por Bielinski (2003) e a outra que se encontra nos arquivos da prefeitura de Petrópolis. É preciso ressaltar que nem todos os Liceus formavam fotógrafos, como profissão. Em São Paulo, por exemplo, a fotografia era uma disciplina e não formação independente.
} 
É reconhecida a importância dos manuais em grande parte dos estudos sobre fotografia no Brasil, materiais essenciais para a difusão do campo no século XIX (Turazzi, 1995, 1997; Vasquez, 2000; Ribeiro, 2003). Muitos desses livros foram escritos por amadores que pertenciam às principais sociedades da época como Louis Alphonse Davanne (1824-1912), membro fundador da Société Française de Photographie, Désiré Von Monckhoven (1834-1882) fundador da L'Association Belge de Photographie, etc. A partir da década de 1880, houve uma grande mudança. Havia equipamentos e processos químicos mais modernos (como a placa seca que substitui o colódio úmido) momento em que clubes e publicações se direcionam exclusivamente para os fotógrafos amadores. Haveria novos autores que também escreveriam manuais e fundariam associações como Albert Londe ${ }^{12}$. Mas as edições portuguesas eram muito poucas. Identificamos no século XIX apenas o Tratado teórico e prático de photographia (1866) de J. A. Bentes. Havia também as edições brasileiras da Livraria Garnier do Tratado elementar de fotografia práctica (1907) e As aplicações da fotografia (1911) ambos de Gaston-Henri Niewenglowki ${ }^{13}$. Quantidade extremamente reduzida se compararmos com as publicações aqui disponíveis nos idiomas francês, inglês e italiano.

As revistas e jornais especializados são outros suportes extremamente divulgados naquele período e muito referenciados em trabalhos de história da fotografia no Brasil (Ibid.). Tinham perfil diferente, sendo menos formais, pois relatavam reuniões, visitas e excursões que haviam ocorrido nos clubes, concursos de fotografia, congressos, etc. Era muito raro encontrar propagandas de equipamentos em suas

\footnotetext{
${ }^{12}$ Albert Londe (1858-1917) trabalhava no hospital de Salpêtrière em Paris. Suas pesquisas estavam relacionadas à aplicação da fotografia à medicina e ao problema do instantâneo. Foi autor de $L a$ photographie médicale. Application aux sciences médicales et physiologiques (1893); La photographie instantanée (1886); La photographie dans les arts, les sciences et l'industrie (1888) e, ainda, Du rôle de l'amateur de photographie au point de vue artistique et scientifique (1893).

${ }^{13}$ Niewenglowski publicou Notions élémentaires de photographie a l'usage des amateurs (1892) e fundou a Société des jeunes amateurs photographes na década de 1890.
} 
páginas e, em geral, não se aprofundavam nos processos técnicos como os manuais. Por isso, havia seções que informavam ao público quais haviam sido as publicações mais importantes do ano ou semestre. Algumas tiveram longa duração como o Bulletin Belge de Photographie (da Société Belge de Photographie) ou o Bulletin de la Société Française de Photographie. No entanto, muitas eram independentes ou ligadas a clubes de amadores como Paris-Photographe (1892-1896), L'Amateur-photographe (Paris, 1885), Amateur Photographer (Londres, 1884), The American Amateur Photographer ${ }^{14}$ (New York, 1889) e Arte Photographica ${ }^{15}$ (Lisboa, 1890).

O terceiro eixo de difusão, formado por revistas ilustradas de caráter geral, não foi estudado aqui e mesmo na bibliografia internacional há pouca relevância ao papel dessas publicações para expansão da fotografia amadora. Para nosso trabalho é uma questão crucial. Produzidas em sua maioria na França, Inglaterra e EUA, tratavam de temáticas variadas. Quase como uma regra, todas tinham colunas sobre fotografia, seja para discutir problemas relativos à técnica e estética, seja para simplesmente divulgar, por meio de propagandas, novos equipamentos que alcançavam popularidade na última década do século XIX. Nas suas páginas a fotografia não era utilizada somente para ilustrar reportagens, mas também na publicidade. Além disso, as revistas promoviam concursos que podiam ser organizados pelo próprio periódico, pelos anunciantes de produtos ou empresas fabricantes de equipamentos fotográficos.

As mais conhecidas aqui eram a L'Illustration (1843-1944), Lectures pour tous, revue universelle et populaire illustrée (1898-192?), Le monde moderne, revue mensuelle illustrée (1895-1908) e a The Graphic magazine, an illustrated weekly

\footnotetext{
${ }^{14} \mathrm{O}$ foto-clube American Amateur Photographer que publicava o The American Amateur Photographer teve como redator Alfred Stieglitz em 1892. Em 1897 esse clube juntou-se com o New York Camera Club dando início ao Camera Club, instituição que desenvolveu papel fundamental na fotografia americana do século XX (Moore, 2005).

${ }^{15}$ Foi publicada por um importante grupo de amadores liderados por Carlos Relvas, um dos mais reconhecidos fotógrafos de Portugal do século XIX.
} 
newspaper (1869-1924). Mas apesar de serem importantes para o campo fotográfico essas revistas não tinham a pretensão, como os manuais, de ensinar a técnica de forma generalizada; cumpriam, porém, o papel de manter o leitor, já praticante da atividade, atualizado com as inovações técnicas, informado sobre as exposições recém inauguradas e problemas decorrentes do aumento do uso de câmeras amadoras no espaço público.

Alberto de Sampaio mantinha assinatura de todas estas revistas. Embora não tenhamos elementos para fazer um tratamento estatístico, sabemos que podiam ser facilmente encontradas em intuições de ensino, bibliotecas públicas e particulares até a década de $1920^{16}$. Havia inclusive correspondentes na Ilustração Brasileira e encontramos na Revista Brasileira artigos traduzido da The Graphic. As livrarias eram outro espaço de difusão. As principais que ficavam no centro do Rio de Janeiro, vendiam material importado como a conhecida Livraria Garnier, situada na rua do Ouvidor, ou a Livraria A. Lavignasse Filho \& C., com sede na rua dos Ourives, a qual, em suas propagandas, ressaltava: "acceitam-se assignaturas para qualquer jornal, em qualquer idioma, como tambem encontra-se sempre, as ultimas novidades litterarias e scientificas publicadas na Europa $[\ldots .$. ".

Não podemos afirmar se aqui tais periódicos desempenhavam maior relevância para a expansão da fotografia amadora que nos países europeus ou mesmo EUA, mas, pelo material encontrado, notamos certa preponderância em relação às outras fontes impressas que circulavam no Brasil, principalmente na primeira década do século XX. Tais revistas forneceram também modelo para as publicações nacionais, seja em relação ao título, às temáticas abordadas ou ao papel ocupado pela fotografia.

\footnotetext{
16 As próprias revistas ilustradas nacionais como A Ilustração Brasileira, incluía em suas propagandas, livrarias que anunciavam as últimas novidades que haviam chegado da Europa. Em 1921 a Casa Braz Lauria - Rua Gonçalvez Dias, RJ - vendia um exemplar da Lectures pour tous por 3\$500 e L'Illustration por $2 \$ 200$. Mais $600 \$$ para o envio pelo correio.
} 
Nessas publicações, o termo "ilustração" era recorrente, tanto usado diretamente nos títulos como na própria denominação das revistas. Eram ilustradas porque tinham imagens de vários gêneros - fotografias, gravuras - e porque atendiam a um público "ilustrado" com interesses também variados. Havia matérias sobre escritores e suas obras célebres; que tratavam de arquitetura - normalmente numa associação com as belas artes - ou de questões gerais de história e política; e, ainda, havia relatos sobre pesquisas científicas e sua aplicação em novos equipamentos disponibilizados para o uso doméstico.

Devido a essa amplitude de temáticas é preciso considerar o termo "ilustração" como uma palavra chave para se compreender a ampla difusão e alcance dos periódicos. Embora atendessem a uma demanda própria, o consumo desses materiais se estabelecia num diálogo com outras práticas do século XIX, que caracterizavam um determinado padrão de comportamento das classes mais elevadas. O público "burguês", como Michelle Perrot (2003: 309) se referencia aos grupos franceses que escreviam diários e genealogias familiares, ao mesmo tempo nutriam interesse colecionista que se expressava na constituição de "museus particulares". Nada melhor do que as revistas ilustradas para condensarem a ilusão de que era possível se apropriar do mundo, estando nos recintos particulares das bibliotecas.

As revistas funcionavam também como uma espécie de vitrine para os eventos sociais e políticos, que tinham significado para os países nos quais os acontecimentos eram relatados. $\mathrm{O}$ alcance desses periódicos, no entanto, era muito amplo chegando a países como México, Argentina, Uruguai e Brasil ${ }^{17}$ e áreas coloniais européias como os continentes Africano e Asiático. Ultrapassavam assim as barreiras regionais e serviam

\footnotetext{
${ }^{17}$ A própria coleção Sampaio é uma testemunha dessa circulação. Ele publica na Lectures pour tous em 1902, na seção "Cartes illustrées echanges", anúncio com seu endereço em Petrópolis. Recebe resposta de pessoas que estavam em quase 20 países diferentes. Na América do Sul recebeu cartões apenas do Uruguai (e encontra um fotógrafo amador) e Argentina; no hemisfério norte os envios foram feitos de Portugal à Turquia.
} 
como um importante meio de difusão cultural, tendo certamente impacto nas diferentes regiões por onde circulavam.

Tom Gretton (1997: 100), por exemplo, aponta alguns aspectos sobre a circulação dos periódicos ingleses. Para o autor, apesar de existirem diferenças entre as revistas publicadas em fins do século XIX - em relação às formas de documentar os problemas sociais e no próprio papel desempenhado pela imagem fotográfica - é possível estabelecer algumas características gerais como sendo comuns. Todas as revistas se reportavam a um leitor que, além de estar interessado em temas diversos como política, economia, história e literatura, buscava, do mesmo modo, se manter atualizado com as últimas inovações tecnológicas. Situado em países distintos, esse leitor tinha perfil sócio econômico semelhante, mesmo aquele localizado nas colônias da Inglaterra e França, para o qual os periódicos desempenhavam a função de mantê-lo em contato com a metrópole.

No caso do Brasil, podemos dizer que o consumo desses materiais servia como meio de contato com tudo o que ocorria nos países desenvolvidos. Servia, portanto, pelo valor social atribuído, papel de certa forma "exacerbado", ampliado para além de suas funções iniciais. O problema da revista estrangeira como distinção foi muito bem apontado pela descrição de um personagem de Afrânio Peixoto no romance A Esfinge (1911). O Dr. Vicente da Câmara funcionava como um polarizador ao condensar em seus atos diversos mecanismos para alcançar prestígio e ter acesso às esferas do poder, um "tipo social" apresentado como muito comum nos salões da capital do país e nas recepções da cidade de Petrópolis. Havia certo artificialismo em seu comportamento, que se pautava em leituras de livros de citações e de publicações estrangeiras, conforme o autor descreve com ironia: 
"Como era preciso impressionar bem aos homens sérios, assinava a Revista dos Dois Mundos. [...]. Lia o título dos artigos, mas não se esquecia de cortar cuidadosamente as páginas: examinara sempre se alguma não escapara" (1962: $81)$.

Afrânio Peixoto aqui se refere à Revue des Deux Mondes (1829), umas das mais antigas publicações francesas com ampla circulação no Brasil, que integrava inclusive a bibliografia dos cursos de engenharia da Escola Politécnica do Rio de Janeiro. Essa revista, embora tivesse importantes colaboradores na área de literatura, não incluía a fotografia como temática. No entanto, é um exemplo claro da penetração desse tipo de material no Brasil.

As revistas ilustradas nacionais, muitas delas seguindo modelo direto das publicações estrangeiras, seriam mobilizadas de maneira semelhante pela classe dominante. Mas, nesse caso, conforme muito bem ressaltou Ana Maria Mauad (2008: 150), serviriam para consolidar determinado modo de vida para homens de perfil burguês, que incluía comportamentos e espaços de vivência social. Para autora, o papel dessas revistas era diversificado, pois servia para tal classe como um meio altamente eficaz de identificação com quadro cultural mais amplo, vetor (lugar de autorepresentação e elaboração de códigos) e, seu consumo exprimia simbolicamente valores e certo prestígio.

Algumas dessas revistas nacionais, que surgiriam a partir desse momento, tiveram também papel relevante para cultura amadora. Foram as primeiras publicações a divulgarem textos em português sobre fotografia e, ao mesmo tempo, serviram de suporte para que se constituísse no Brasil um circuito público fotográfico de forma independente das instituições oficiais. Encontramos duas revistas muito importantes nesse contexto, com perfis distintos. A primeira é a Leitura para todos (19031914/1919-1930), que tinha caráter informativo, podendo ser incluídas em suas matérias 
questões mais irreverentes, sem haver grandes compromissos com a questão estética (o modelo era a revista francesa Lectures pour tous). Ali havia a coluna "A prática photographica", publicada até 1910, onde encontramos artigos técnicos. Abordavam-se problemas de revelação, novos métodos como a introdução da fotografia colorida e, além disso, eram divulgadas discussões teóricas sobre o tema e concursos locais destinados aos amadores.

O segundo periódico é a Renascença (1904-1908), revista refinada que conferia grande espaço para as manifestações artísticas. Tendo como um de seus diretores Henrique Bernadelli e, entre os colaboradores, escritores e artistas renomados, pode ser considerada, também, como um braço do recém inaugurado Photo-Club do Rio de Janeiro. O clube não tinha publicação própria (o Photo-Club de Paris, por exemplo, tinha o Bulletin do Photo-Club de Paris, 1891; e depois, La revue de photographie, 1903), por isso, a Renascença foi o único meio impresso que divulgava notícias sobre as exposições. E, ainda, foi a primeira revista a dar crédito aos fotógrafos, valorizando os autores das imagens que podiam tanto ser amadores como profissionais.

Havia uma terceira publicação que merece destaque, embora o espaço conferido à fotografia amadora tenha sido mais modesto. Trata-se da Kosmos (1904-1909), também voltada para um público de elite, a qual cobria as principais mostras artísticas da cidade. O periódico divulgou um conjunto de imagens do Photo-Club do Rio de Janeiro em 1904 com o título "A exposição do Photo-Club". Temos ainda o artigo "A arte"18, um longo comentário do jornalista Eunápio Deiró sobre texto extraído de alguma revista estrangeira, que apresenta os principais postulados debatidos no período.

\footnotetext{
${ }^{18}$ Ricardo Mendes foi o primeiro a fazer referência e análise desse texto, que aparece mencionado em Fotografia e Modernismo: um breve ensaio das idéias fora do lugar. São Paulo: FotoPlus, 1996 (ensaio crítico). Disponível em: www.fotoplus.com/rico/ricotxt/wfm.htm. Publicou também o artigo na íntegra em Páginas Negras N.O37, Eunápio Deiró: comentários sobre arte e fotografia no Brasil de 1904. Disponível em: http://www.fotoplus.com/fpb/fpb037/b037a.htm.
} 
Vale observar que as referências à fotografia na Kosmos já foram diversas vezes mencionadas em nossa historiografia, ao contrário da Leitura para todos e da Renascença, que, embora não tenham sido analisadas, de fato, tiveram contribuição muito mais expressiva para a cultura amadora fotográfica em nosso país.

\section{A Renascença e o Photo-Club do Rio de Janeiro}

As matérias sobre o Photo-Club do Rio de Janeiro na Renascença são fundamentais para a compreensão do circuito fotográfico da primeira década do século $\mathrm{XX}$, material ainda desconhecido, que encontramos no curso da pesquisa. Até hoje, nos livros sobre a história da fotografia no Brasil, consta que o Photo-Club do Rio de Janeiro foi fundado apenas em 1910, sem haver nenhum dado sobre o que teria ocorrido até 1923, quando surge o Photo Club Brasileiro.

Mas a revista nos indica uma situação diversa. Ali estão mais longos comentários sobre o modelo de fotografia artística difundido nos circuitos amadores. Foi também o meio pelo qual obtivemos a informação sobre a existência do clube, responsável pela organização de exposições em 1904 e 1905 na rua do Ouvidor, na Galeria Cambiasso. Em 1907, a última mostra, ocupou o recém inaugurado Museu Commercial do Rio de Janeiro, situado na Avenida Central.

É preciso ressaltar que esta não foi, certamente, a única experiência clubística do período. Há referências esparsas sobre a existência de clubes no início do século XX em vários trabalhos. Boris Kossoy (2002: 299) destaca a formação de uma Sociedade de Fotografia no Rio de Janeiro em 1892. Suzana Barretto Ribeiro (2006: 93, grifo original) apresenta o papel timbrado da empresa de A. Leterre em 1902 (profissional sediado no centro do Rio), em que há um pequeno texto dizendo que aquele estúdio era sede do "club photographico e da revista photographica". Há ainda menções na cidade 
de Porto Alegre, ao Helio Club em 1904, apontado por Eneida Serrano (1979). O próprio Boris Kossoy (1980: 85) fala de um Sploro Photo-Club, que organizou, também em 1903, uma exposição de artes plásticas nessa cidade. Menciona a Revista Photographica lançada em São Paulo em 1909, que seria a primeira publicação destinada exclusivamente à fotografia no Brasil. Solange Ferraz de Lima (1998: 75) se refere ao Photo Club, inaugurado em 1900, na capital paulista.

São informações importantes porque nos fornecem indícios da existência de outras associações. Em todos os casos, porém, só temos referência ao nome do clube, publicação, ou apenas menções esparsas (pela própria dificuldade de encontrar informações). Portanto, os dados que encontramos na Renascença são de grande valor pela riqueza do material. Ali percebemos que, com a fundação do Photo-Club do Rio de Janeiro, as mostras organizadas seriam muito diferentes da última exposição que teve participação de fotografias na cidade, a qual estava vinculada, como vimos, a instituições públicas nas comemorações do quarto centenário do descobrimento do Brasil em 1900. Havia de fato um ineditismo no Photo-Club, que se deve a três circunstâncias principais: foi responsável pela organização das primeiras mostras de fotografia de forma independente no Rio de Janeiro; utilizou a imprensa ilustrada como um suporte para dar visibilidade pública ao grupo; e, principalmente, introduziu "socialmente" um novo ator no cenário fotográfico, o amador.

Dentro de um contexto incipiente para os amadores, eles utilizarão amplamente os meios impressos, como revistas ou material próprio (no caso, há menções nas matérias sobre um catálogo que continha parte das fotografias expostas e comentários escritos). No caso da Renascença, os artigos traziam inúmeras fotografias que podiam estar também em páginas avulsas, situadas no meio da revista. Em ambos os casos, era dado crédito ao autor e fazia-se referência ao clube, recurso utilizado até mesmo nos 
anos que não havia exposições como em 1906 e 1908. A revista era utilizada assim de forma permanente para manter a visibilidade pública do Photo-Club.

A estrutura dos artigos se assemelhava ao que ocorria em matérias das revistas estrangeiras sobre exposições fotográficas, em que havia uma pequena introdução seguida de comentários sobre as imagens. No conjunto, foram publicadas 37 fotografias de amadores e duas de profissionais associados ao clube, entre 1904-1908, das quais 30 imagens eram de autoria dos quatro membros mais ativos nesse momento: Alfredo Ferreira Laje (11 fotos), Barrozo Netto (8 fotos), Sylvio Bevilacqua (6 fotos) e Guerra Duval (4 fotos). Com esses integrantes podemos caracterizar o clube de maneira geral: era formado por homens de perfil burguês, em sua maioria jovens; alguns, inclusive, tiveram contato direto com o que ocorria na Europa. Não dependiam, portanto, apenas das publicações estrangeiras como meio de formação principal ${ }^{19}$.

Um dos mais representativos, sem dúvida alguma, era o presidente do clube, Alfredo Ferreira Laje (1865-1944). Esse advogado, com condições financeiras privilegiadas, não se dedicou apenas à fotografia, mas também à atividade do colecionismo. Em sua residência fundaria, ainda em vida, um museu para abrigar todas as obras de arte adquiridas ao longo de vários anos, no Brasil e no exterior ${ }^{20}$. Era também primo de segundo grau de Alberto de Sampaio. Embora não tenhamos registros da relação entre esses amadores, há vários indícios da proximidade entre os dois ramos familiares, conforme iremos mostrar posteriormente.

Alfredo Ferreira Laje, porém, teve atuação apenas nesse primeiro momento do clube. Outros amadores continuariam a exercer papel fundamental no campo fotográfico

\footnotetext{
${ }^{19}$ Ricardo Mendes ressalta que Sylvio Bevilacqua participava de concursos promovidos pelo Photo-Club de Paris desde 1903. Disponível em: http://www.fotoplus.com/fpb/fpb037/b037a.htm.

${ }^{20}$ Alfredo Ferreira Laje era filho de Mariano Procópio Ferreira Laje, que construiu a Estrada União e Indústria, primeira estrada macadamizada do Brasil que ligava Petrópolis à Juiz de Fora. Revert Henrique Klumb, ao longo de 11 anos, fotografou a estrada publicando um livro, em 1872, Doze horas em diligência: guia do viajante de Petrópolis a Juiz de Fora (Vasquez, 1998). Alfredo Laje, em sua residência em Juiz de Fora, fundou, em 1936, o Museu Mariano Procópio.
} 
como foi a caso de Fernando Guerra Duval (?-1950), que utilizava a fotografia não apenas como um passatempo. Era um amador engajado, possivelmente um dos mais atuantes da primeira metade do século XX. Também não trabalhava em outra atividade com a qual recebesse remuneração. Tinha condições financeiras favoráveis que permitiam a dedicação integral à fotografia, sem nunca ter dependido dela economicamente. Foi um dos fundadores do Photo Club Brasileiro em 1923, período em que começou a organizar exposições, escrever artigos de caráter geral e publicar suas imagens em revistas como a Ilustração Brasileira e O Cruzeiro. Escreveu ainda sobre assuntos técnicos ligados à fotografia na Revista Nacional de Educação, nos anos 1930.

Sylvio Bevilacqua ${ }^{21}$ (?-1948) também foi uma figura muito expressiva no circuito fotográfico no período posterior à fundação do Photo-Club do Rio de Janeiro. Podemos considerá-lo como um caso particular uma vez que ficou na fronteira entre a atividade amadora e profissional. Exerceu durante alguns anos o cargo de professor de português no Colégio D. Pedro II e em outras escolas no Rio de Janeiro. Mas era muito conhecido na cidade como o fotógrafo da elite carioca. Na década de 1910 , já como freqüentador dos principais "salões", como o de Laurinda Santos Lobo e da esposa do escritor Coelho Neto, abre um estúdio próprio. Colabora com a Revista da Semana, sendo o fotógrafo escolhido para as matérias principais, assinadas com o título "Clichê Bevilacqua". E teve atuação na revista $O$ Cruzeiro que, como destacou Helouise Costa (1998: 277), junto a Fernando Guerra Duval, promoviam inclusive concursos fotográficos.

Havia, porém, outros membros do clube com profissões distintas. Joaquim Antonio Barrozo Netto (1881-1941), por exemplo, era muito atuante neste momento.

\footnotetext{
${ }^{21}$ Era filho de Francisco Alfredo Bevilacqua (1846-1927), professor de piano, compositor e um dos fundadores do Instituto Nacional de Música. Uma de suas filhas, Zélia Bevilacqua se casou com um de seus alunos, Joaquim Antonio Barrozo Netto.
} 
Foi professor do Instituto Nacional de Música e compositor reconhecido - era cunhado de Sylvio Bevilacqua com quem inclusive, compôs algumas músicas. É provável que o Delgado de Carvalho ${ }^{22}$, que participou de pelo menos uma das exposições, seja outro professor do mesmo Instituto. E ainda há Pedro Peres ${ }^{23}$, possivelmente o artista e professor que lecionava na então Escola Nacional de Belas Artes. Outro fotógrafo, mencionado neste momento, foi Oscar de Teffé, um advogado e diplomata como diversos membros do clube ${ }^{24}$. Nas matérias da Renascença há referências às suas constantes viagens ao Exterior. Mais tarde foi embaixador do Brasil em Roma substituindo Adalberto Guerra Duval, o irmão de Fernando Guerra Duval.

Cumpre lembrar que a maior parte desses fotógrafos freqüentava Petrópolis. Fernando Guerra Duval, anos mais tarde, na década de 1920, foi ali um dos fundadores do primeiro Sindicato do Turismo. Alfredo Ferreira Laje manda construir duas casas na cidade, na década de 1890. Oscar de Teffé estava associado aos núcleos do Presidente da República (era irmão de Nair de Teffé, casada como Marechal Hermes da Fonseca). Havia fotografias e filmes realizados sobre essa família na cidade, que eram exibidos em Petrópolis, conforme iremos nos referir posteriormente.

Temos aqui um pequeno grupo formado por homens de elite que circulavam nos mesmos circuitos sociais e as relações familiares eram fundamentais. Por isso, o PhotoClub não iria permanecer isolado, formado por aqueles que se reuniam com o único objetivo de promover, discutir ou difundir questões estéticas. Era antes de tudo, um espaço de mediação. O próprio uso da revista ilustrada como meio de divulgação tinha

\footnotetext{
${ }^{22}$ Joaquim Tomas Delgado de Carvalho (1884-1980) é muito conhecido na área por ter sido o autor da ópera Moema com a qual foi inaugurado o Teatro Municipal do Rio de Janeiro em 1909.

${ }^{23}$ Pedro José Pinto Peres (1841-1923) teve trajetória profissional característica de muitos pintores de seu período. Estudou no Liceu de Artes e Ofícios e depois ingressou na AIBA, sendo considerado por Gonzaga-Duque (1995: 206) como o maior discípulo de Vitor Meirelles.

${ }^{24}$ Era irmão de Nair de Teffé, que foi casada com o Presidente da República Marechal Hermes da Fonseca.
} 
como efeito conferir ao clube maior difusão e, consequentemente, visibilidade pública ao grupo.

\section{Entre técnica e estética}

Na primeira exposição do Photo-Club, cuja cobertura foi publicada na revista Renascença (edição de julho de 1904), o autor (anônimo) fez um pequeno diagnóstico da situação aqui encontrada. Esse trecho merece destaque, pois menciona brevemente os materiais utilizados por aqueles que praticavam a fotografia no Brasil, aponta as referências para o clube recém-fundado e, por último, apresenta alguns tópicos sobre a relação entre fotografia e pintura. Trata-se de uma apresentação inicial e, por isso, há esse diagnóstico, que difere dos textos publicados nas exposições seguintes.

No início do artigo não há polarização entre amadores e profissionais. Aliás, o autor se refere aos amadores de forma genérica, sem ter a preocupação de delimitar o clube como um espaço exclusivo para um determinado grupo. A situação muda nos comentários sobre as imagens expostas, cuja referência precisa ao "amador" prepondera em relação ao uso do termo "fotógrafo". Então, apesar de não haver uma delimitação clara, nessa primeira exposição havia apenas amadores.

O artigo "A Exposição do Photo-Club" começa informando sobre a recepção da mostra e seu sucesso:

\footnotetext{
“Ah! Não há dúvida que vocês entraram no domínio da verdadeira arte - ouviu muitas vezes dizer quem escreve estas linhas; e, assim, de bocca em bocca, o sucesso se foi espalhando pela cidade e muitos correram a ver e examinar essa exposição de arte, feita exclusivamente com recursos photographicos [...]" (7/ 1904: 197, anno I, n.5).
} 
Podemos dizer que essa foi a primeira exposição em que a fotografia tinha exclusividade, daí a necessidade de manifestar esse impacto, que nas linhas seguintes, o autor menciona como uma "verdadeira revelação" (Ibid., grifo original). Mas ele reconhece que tal revelação era apenas para aqueles que desconheciam o que ocorria no Exterior. Isso porque, em nosso país, havia muitos fotógrafos, que viviam "no segredo da nova arte". Menciona depois a questão que consideramos ser central: diz que muitos aqui se dedicam à fotografia "com amor e que della tudo sabem porque dos países estrangeiros recebem jornaes e publicações artísticas [...]” (Ibid.).

Este dado é importante e corrobora nossa hipótese sobre a importância das revistas ilustradas estrangeiras para o campo fotográfico daquele período, incluídas aqui na denominação “publicações artísticas”. Como já destacamos, esses periódicos também tinham a fotografia como temática comum e desempenharam papel crucial em nosso país. O amplo consumo desses materiais não era, portanto, um caso exclusivo de Alberto de Sampaio. Mas além dos grupos formados por aqueles que lêem material estrangeiro:

\begin{abstract}
"ninguém mais há aqui sciente de que na Europa e nos Estados Unidos a photographia é hoje uma arte amada e respeitada, que os artistas photographos têm em França entrada no Instituto, que lá recebem as palmas da Academia e são officiaes da Legião de Honra; ninguém sabe que a escola de photographia do professor Eder, em Vienna é mantida pelo governo e que occupa um edifício maior que nossa Imprensa Nacional; ainda nesse ano o Salon do Photo-Club de Paris recebeu a vista oficial do presidente da republica e teve a honra de vêr alguns de seus trabalhos reproduzidos em jornaes de arte que em outros tempos só reproduziam os trabalhos dos pintores e esculptores" (Ibid.).
\end{abstract}

É sugestivo que no início do texto trate-se justamente do problema da distinção e posicionamento social dos membros desses Photo-Clubs. O autor lembrava que esta era uma atividade de alto prestígio, de amadores articulados, reconhecida pelas esferas governamentais no Exterior. Não era, portanto, um grupo qualquer. Havia problema da 
formação que, em Viena ${ }^{25}$, contava com a mais prestigiosa e bem montada escola de fotografia dos países europeus. Tinha edifício próprio e atendia a amadores e profissionais.

Depois o autor menciona quais os fotógrafos serviam de modelo para o que estava acontecendo no Rio de Janeiro. Havia, no grupo, franceses do Photo-Club de Paris, e ingleses do Linked Ring: os "grandes artistas da photographia que se chamam Puyo, Demachy, Steichen, Bergon, Horsley-Hinton e outros, muitos outros" (Ibid.: 198).

Mas se a proposta era vincular a fotografia à pintura, haveria disputa entre os dois campos? A uma primeira vista podia parecer que sim, mas o autor logo de início esclarece a questão, apresentando um consenso. O pintor aparece como aquele que dominava uma técnica superior, mais difícil que a fotográfica, por isso ele ressalta que os fotógrafos não deveriam imitar a pintura. $\mathrm{O}$ que se pretendia era aproximar as duas formas de expressão pelo uso de técnicas específicas. Desta forma, esses novos fotógrafos são considerados grupos de formação:

“[...] do desenvolvimento da photographia muita vantagem sahirá para a pintura porque, quando o grande numero de amadores que se dedicam aquella compreender todos os segredos da esthetica commun, os pintores terão sem dúvida, muito maior número de admiradores para a prodigiosa difficuldade que constitue a principal e maior differença das duas artes -a technica. Se é verdade que a inspiração póde ser igual no pintor e no photographo, é também incontestável que a photographia deve olhar com humilde respeito para a superioridade da technica de sua irmã mais velha, superioridade que dá a pintura muito maior latitude de interpretação mas que também, as vezes, absorve completamente a faculdade creadora" (Ibid.).

Essa superioridade reconhecida da pintura, contudo, poderia se tornar desvantagem. Isso porque como o domínio técnico era primordial:

\footnotetext{
${ }^{25}$ A École Impériale et royale de photographie foi fundada em Viena, em 1886. As revistas de fotografia sempre traziam matéria sobre seu funcionamento como a Paris-Photographe de fevereiro de 1892.
} 
"nas exposições de pintura admiramos às vezes quadros que seriam banalíssimos se não fossem executados com grande maestria o que não se dará com os trabalhos photographicos porque a técnica é relativamente tão fácil e simples que, se o quadro não indicar um esforço meritório da fantasia, elle passará despercebido" (Ibid.: 199).

Mesmo de forma subliminar, o autor, que antes havia visto uma superioridade da pintura, ao final inverte a situação. Cabia à fotografia ter maior potencial para expressar a "fantasia", a criação da obra, pois ali a técnica relativamente fácil deixava transparecer muito mais as idéias e proposições. Tal juízo de valor revela uma característica importante desses grupos, que era a polarização e a criação de tensões até mesmo dentro do próprio movimento. Uma situação muito presente nos países de origem desse modelo de "fotografia artística", e que, na sua adesão, provocará aqui articulações próprias.

Mas como implantar tais modelos num país como o Brasil? Haveria diferenças locais? O material disponível para essa análise é escasso. Além das matérias da revista Renascença, temos o artigo produzido por Eunapio Deiró para a Kosmos em 1904, tradução direta de algum artigo estrangeiro reproduzido "ora fielmente, ora com aquella ampla liberdade [...]" (11/1904, anno I, n. 11). Já na Renascença, os diferentes autores escrevem livremente sobre as fotografias expostas (Von Ab. Eff na segunda exposição e Álvaro de Lima na terceira). Analisando essas fontes observamos que, sobretudo na primeira exposição, havia pequenas contradições entre os postulados teóricos adotados e a análise das fotografias.

Começaremos então por Deiró, que apresenta claramente os principais pontos debatidos no período. Por ser um comentário sobre um artigo francês, consideramos que, nesse caso, há provavelmente maior fidelidade às questões apresentadas. Logo no começo do artigo, o autor diz que irá abordar problemas de estética, um tema certamente amplo demais. Mas escolhe - e comunica ao leitor - que o debate sobre a imitação da natureza, já superado nas discussões sobre pintura, escultura, gravura e 
demais áreas afins será aqui tratado em relação à produção de imagens fotográficas. De fato, essa era a questão central para aqueles que procuravam validar a fotografia como um meio de expressão artística - sejam amadores ou profissionais que buscavam se diferenciar no campo.

Fazendo comparação com o modelo considerado do passado, o autor assim se refere ao problema:

\begin{abstract}
"A orientação dos photographos era então, como ainda hoje - que quanto mais uma prova mostra, minúcias, tanto mais bella é; e, quando as mostra mais nitidamente - ainda melhor, porque attinge o fim; importa que, á vista da photographia d'uma cidade, cada contemplador possa contar, uma por uma, as casas e, em cada casa distinguir as janellas e dizer: aquella é a minha casa e a cortina está fechada!"' (Ibid.).
\end{abstract}

Aqui aparece a crítica, comumente proferida nesse momento, à fotografia como reprodução fiel da realidade. A nitidez e profundidade de campo, nessa perspectiva, não eram mais reconhecidas como qualidades da prova fotográfica. Poder enxergar os detalhes com precisão, contrariava o próprio processo da visão. Desta forma, Deiró se refere indiretamente às teorias em voga baseadas em preceitos fisiológicos que postulavam determinados "defeitos" como parte inerente à experiência do olhar. Aproximar tal percepção da produção fotográfica significava associar imagens produzidas tecnicamente às normas estéticas vigentes na pintura.

O debate se pautava nas pesquisas sobre a fisiologia da visão do cientista alemão Hermann Von Helmholtz (1821-1894) que, ao estudar a percepção ocular, demonstrou a existência de imperfeições e campos fora de foco. Postulados que estariam presentes nos trabalhos do mais influente amador da última década do século XIX, Peter Henry Emerson (1856-1936). No livro Naturalistic Photography de 1889, este autor se apresenta contrário às manipulações posteriores na imagem, valorizando a falta de nitidez, assim registrada, com auxílio de lentes especiais. A função da fotografia 
artística seria a de reproduzir a impressão visual, denotando que a "verdade" fotográfica estaria mais na percepção subjetiva da realidade do que na tradução mimética, precisa, daquilo que era registrado. Ele se contrapunha a vertente de Henry Peach Robinson, fundador do Linked Ring Brotherhood ${ }^{26}$ e autor de livros importantes, para o debate "pictorial”. Diferentemente, Robinson valorizava muito mais composições convencionais utilizando, para isto, diversas manipulações no suporte. Podiam ser vários negativos em conjunto (que possibilitavam sobreposição de cenas), com auxílio de técnicas manuais aplicadas diretamente na imagem (Joschke, 2005: 220; Sternberger, 2001: 91).

No Brasil, tais questões foram referenciadas no trabalho pioneiro de Maria Tereza Bandeira de Mello (1998), na análise da formação do Photo Club Brasileiro em 1923. Não apresentamos, portanto, nenhuma novidade. Porém, com o material encontrado objetivamos identificar como foram os primeiros contatos com o que ocorria nos países, sobretudo, europeus, assim como as primeiras tensões dentro do movimento em nosso país

Nesse sentido, o texto de Deiró já manifesta as duas problemáticas centrais do debate, altamente normativas, que perdurariam nas décadas seguintes: a questão da intervenção e do posicionamento no espaço. A intervenção estava vinculada mais diretamente ao problema da nitidez. Os amadores utilizavam não apenas técnicas específicas como a goma bicromada, o processo do carvão e o bromóleo, para alterar a própria característica fotográfica das imagens. Eles foram além, produzindo na França Puyo e Pulligny - lentes especiais, muito empregadas para o retrato, chamadas de "anachromáticas". O resultado era um efeito fora de foco que eliminava o que se considerava como defeito, a definição precisa das formas:

\footnotetext{
${ }^{26}$ Henry Peach Robinson foi autor de Pictorial effect in photography (1869) e fundou o Linked Ring, em 1892, em Londres (Mello, 1998: 27).
} 
“[...] supprimir certos defeitos da imagem photographica é cousa excellente [...].

De feito, o nosso autor tem razão, porque a questão não versa sómente em saber - si a photographia possue as mesmas qualidades, que outros processos artísticos, porém se possue alguns, que sejam dignos de serem comparados; si o papel do artista é muito importante para modificar o aspecto d'uma obra; emfim, si intervem muitas vezes para aquinhoar na produção e não ter simplesmente parte na reprodução e que se tem o talento de accrescentar á beleza do sítio, que a todos pertence - uma Idea, um sentimento exclusivamente seus" (Ibid.).

A fotografia assim não poderia servir de registro natural dos sentimentos, ou expressar a individualidade do autor das imagens. Seria necessário, antes, haver trabalho de "intervenção", que podia acrescentar e, muitas vezes, suprimir elementos da imagem. Daí a importância, para esses grupos, do aporte teórico. O objetivo era claro, mostrar que também na atividade fotográfica, a "interpretação" seria uma categoria relevante.

Para isto, problematizava-se a questão espacial, que é o segundo eixo dessas proposições. Havia um termo específico, o "ponto de vista”, inúmeras vezes referido em artigos de revistas e manuais do período. $\mathrm{O}$ amador artista deveria procurar se deslocar no espaço para ali encontrar um ângulo original. Disparar o botão, reproduzindo apenas o que era percebido pelos olhos significava se render as propriedades mecânicas do equipamento:

"Assim é uma sciencia - o achar o ponto justo d'onde o objecto deve ser visto e
considerado e não só o ponto mas a estação,a hora, o tempo, a razão de ser do
motivo - Quis, quid, ubi, quibus, auxilus, cur, quomodo, quando.
Em verdade, o mais bello objecto do mundo poderá ser um medíocre assumpto
para um quadro, si não for visto sob o ângulo apropriado e conveniente - no
momento esthético" (Ibid.).

Todo esse discurso, portanto, tinha como pano de fundo a crítica aos aparatos tecnológicos, e de alguma maneira, à fotografia. Tais questões, amplamente discutidas, 
podiam ser encontradas em quase todos os comentários sobre as exposições dos PhotoClubs franceses, nas revistas estrangeiras. Mas no artigo sobre a exposição de 1904 na Renascença, há sinal de alguma contradição. Nas referências a Alfredo Ferreira Laje, o autor dizia: "compõe por deslocação, e essa faculdade especial de escolher o ponto" (7/1904: 199, anno II, n.5). Ao mesmo tempo, no final da matéria, menciona o Secretário da Legação Alemã, Haniel, como um "paisagista exímio" em cujas fotografias vigoram “a justeza da exposição sem a qual não é possível obter todos os detalhes" (Ibid.: 201). Aqui, o problema do ponto de vista é contemplado, no entanto, elogia-se uma imagem com nitidez exacerbada, exatamente o que era criticado por esses amadores (e no texto de Deiró).

De fato, não eram essas as imagens que mais fizeram sucesso na exposição, mas as paisagens que utilizavam a técnica em carvão, de Guerra Duval e Barrozo Netto, que ressaltavam os contrastes o "tom sanguinea terroso para não dizer barrento" dos locais registrados (Ibid.: 200). Mas nas revistas estrangeiras, que aqui circulavam, era mais difícil encontrar contradições na defesa de tais preceitos nesse momento. Fotografia com muita nitidez, na maioria das vezes, era considerada inferior, demonstrando apenas a capacidade técnica do equipamento e não do autor das imagens. Assim aparece na revista The Graphic de 1895, um comentário sobre o "Photographic Salon at the Dudley Galery":

"No picture is admitted to the photographic salon unless it bears evidence that its producer has aimed at an artistic result rather than that accuracy of detail and sharpness of line which used to be considered the first essential of a photograph" $(28 / 9 / 1895: 390){ }^{27}$

\footnotetext{
${ }^{27} \mathrm{O}$ autor do artigo era M. H. Spielmann, um importante crítico de arte, editor da revista The magazine of art, escreveu biografias de artistas como John Ruskin (1890). Esse comentário está na coluna "An artistic causerie" na qual há o tópico "The Photographic Salon".
} 
Na França, Maurice Bucquet ${ }^{28}$, diplomata e presidente do Photo-Club de Paris, publica artigos na Le monde moderne. Em seus comentários sobre uma das exposições desse clube, não havia também divergências:

«Ce n'est pas seulement par des qualités de fini, d'execution irréprochable, de technique parfaite, que l'on peut prétendre à retenir l'attention de critiques sérieux : ceux qui sacrifient d'un façon trop absolue à ces qualités sont précisement ceux-lá qui nuisent le plus à l'elévation de la photographie et la rabaissent le plus au niveau d'un procédé de reproduction, merveilleux, il est vrai, mais sans valeur artistique acune » (6/1897: 277, 3e année).

Mas o debate era acirrado e, por isso, questionamentos a respeito da fotografia como registro da percepção de determinado evento ou como representação fiel à "realidade" foram retomados em diversas ocasiões. Na Inglaterra e mesmo nos EUA, como Paul Sternberger (2001: 65) evidenciou em seus trabalhos, havia também resistência à concepção naturalista da fotografia, que valorizava a impressão e atributos subjetivos da imagem. Isso teria certamente reflexos no Brasil. Na terceira exposição do Photo-Club do Rio de Janeiro, em 1907, há breve menção a tais debates. O autor do artigo, Álvaro de Lima, nos informa que na Inglaterra surgiram grupos, "há dois annos", que propunham a volta às antigas técnicas e criticavam todo tipo de retoque na imagem, retomando a "precisão do detalhe, a minucia excessiva, a nitidez absoluta e até o detestável tom photographico dos papeis citrato e albuminado" (11/1907: 246, anno IV, n. 45).

Então de forma mais veemente ainda, o artigo supervalorizava todas as técnicas utilizadas para alterar a natureza fotográfica das imagens, desde procedimentos químicos até o uso das lentes especiais fabricadas na França. Apresenta-nos, entretanto, outra distinção, agora entre a fotografia e a pintura. A fotografia ao invés de imitar a

\footnotetext{
${ }^{28}$ Segundo Michel Poivert (2001: 19), Maurice Bucquet era Cônsul da República de San Marino.
} 
pintura pretendia sim, segundo ele, "rivalizar" "sem enganar a ninguém", pois todos esses efeitos que eram produzidos na cópia "conservam um cunho próprio que é somente della". Apesar de a técnica ser acessível, esses "cultores da nova arte" só eram assim considerados se utilizassem a "faculdade creadora" (Ibid.:250). Aqui há um posicionamento mais crítico em relação às duas formas de expressão artística. Isso porque a terceira exposição do Photo-Club fora organizada dentro do "Salão livre de Bellas-Artes" no Museu Commercial do Rio de Janeiro, dividindo assim, pela primeira vez, espaço com pinturas.

\section{A Kodak e a fotografia}

Para entender a cultura amadora, não basta referir-se à vida nos clubes e seus desdobramentos. A fim de tratar dessa faixa de amadores singulares, convém examinar como a técnica fotográfica (máquinas e processos) permitiu a incorporação de grandes contingentes de praticantes. A esse respeito, nada melhor que acompanhar a trajetória da Kodak Co. - principal indústria de aparelhos fotográficos e de um sistema altamente eficaz de serviços de laboratório.

O lançamento da Kodak ocorreu em 1888 com um equipamento que permitia realizar até 100 fotografias de uma só vez. A bobina em rolo, do filme, já vinha dentro da câmera. As imagens produzidas podiam então ser reveladas no laboratório situado na sede da empresa em Rochester, nos EUA. Mas a grande mudança da Kodak não estava na parte inicial de seu conhecido slogan: "You press the Button, we do the rest". Câmeras anteriores, destinadas a profissionais e amadores avançados já mobilizavam mecanismos que ficavam dispostos nas objetivas dos equipamentos, os quais permitiam puxar uma pequena alavanca de maneira fácil e prática. A novidade aqui era outra. Inserindo-se numa nova economia da produção, a realização de fotografias ficava 
liberada em duas fases importantes: revelação dos negativos e ampliação das respectivas fotos.

Algumas estratégias diferenciaram a Kodak das demais concorrentes que começaram a lançar equipamentos semelhantes em fins do século XIX. Havia, em primeiro lugar, a preocupação com o barateamento das câmeras, além de seu uso simplificado. Como destaca Nancy West (2000: 22), esse primeiro equipamento de 1888 ainda era acessível apenas para as classes mais privilegiadas nos EUA, devido ao preço elevado: cada câmera custava 25 . Mas como a empresa visava ter amplo alcance, alguns anos depois lançou outros modelos como a Pocket Kodak que custava 5 dólares e, finalmente, em 1900, surgiu a Brownie que foi grande impulsionadora das vendas, pois era direcionada para crianças, sendo vendida a apenas 1 dólar. $\mathrm{O}$ equipamento havia sido barateado, porém, as facilidades de uso e mesmo o formato da câmera, que era uma caixa de metal coberta em couro, pouco havia se alterado.

O segundo aspecto a ser destacado foi que a Kodak, para alcançar seu objetivo de expansão, em termos técnicos, criou um sistema próprio que possibilitava a revelação sem uso do laboratório. Para atender a essa demanda, em 1905 surge todo um aparato que objetivava permitir que qualquer pessoa pudesse revelar suas imagens em casa, dispensando-se a necessidade do quarto escuro, fundamental até então para todos os procedimentos fotográficos. Foi assim lançado o Kodak Tank Development um cilindro de metal que possibilitava a inserção do rolo em celulóide para o procedimento de revelação dos negativos e o Elementary Tank Development utilizado para revelar placas em vidro. Obviamente, ainda era preciso ter um termômetro, um relógio e químicas já vendidas pela Kodak a fim de completar o procedimento. Para dar continuidade ao processo, depois que os negativos haviam sido revelados, era necessário passar a imagem para o papel. Para isto, a Kodak desenvolveu uma prensa chamada de Printing 
Frame, também muito simples, onde era introduzido o papel fotográfico junto com o negativo - que continha a imagem a ser revelada. Depois, a exposição à luz solar finalizava o procedimento.

Tudo era extremamente simplificado, quando comparado com o que ocorria dentro do laboratório, onde havia necessidade de preparo de químicas, uso de ampliadores e de uma infinidade de pequenos objetos que compunham essa sala especial. Em termos técnicos, a Kodak se diferenciava, então, dos demais concorrentes por permitir o uso facilitado dos procedimentos fotográficos nas diversas etapas de produção da imagem, desde a captura da cena até a revelação e ampliação dos negativos, que podiam ser realizados em plena luz do dia, em qualquer ambiente.

Há ainda um terceiro aspecto, por certo, fundamental para a difusão de todo esse aparato tecnológico. Trata-se do papel da publicidade que viria a ser o último recurso disponibilizado para completar essa cadeia. Afinal, seria através dela que o produto chegaria ao consumidor. Embora saibamos que a Kodak desde 1888 produzia manuais, que podiam ser adquiridos junto com a câmera, não era através desses suportes, muito comuns no período para os amadores avançados, que a empresa divulgaria seus equipamentos. O principal o meio de comunicação da empresa eram as propagandas publicadas nas revistas ilustradas, que, em fins do século XIX, com os avanços tecnológicos, permitiam que fotografias fossem impressas em suas páginas. Em tais reclames, podia-se falar inclusive das questões técnicas. Na The Graphic, por exemplo, os anúncios destacavam "Daylight loading”, "Daylight developing”, "Daylight printing”. Reiterava-se continuamente a idéia de que tudo podia ser feito à luz do dia, tanto colocar o negativo na câmera como revelá-lo. Apareciam nos anúncios os tanques especiais e as afirmações de que era necessária pouca coisa para produzir fotografias. 
Além disso, a empresa estava em busca de novos consumidores e daí o direcionamento para outros segmentos sociais como as crianças e as mulheres. Nancy West (2000: 38) em sua importante análise sobre a publicidade da Kodak nos EUA destaca que é possível identificar diferentes fases para as propagandas. Inicialmente, se vinculavam as facilidades técnicas, ao uso como lazer, diversão, ou como uma forma de jogo que, segundo a definição de Huizinga, recuperada pela autora, constitui uma atividade concentrada em seus próprios fins, em oposição ao trabalho que privilegia "the end result over the process". O próprio tamanho do equipamento, cujos modelos se tornavam menores na virada do século XIX, constituía um tipo de brinquedo produzido tanto para adultos como crianças. Esse momento de diversão devia ser preferencialmente realizado "out-doors", na natureza. Fotografar estava associado, segundo esses reclames, à idéia de aventura. Só depois de 1915 é que os anúncios começam a ressaltar a noção de que a fotografia era uma forma de preservar a memória, os bons momentos do grupo familiar.

Merece ser ressaltada a função de deslocamento integrante do próprio desenvolvimento material da câmera fotográfica. Inicialmente, os equipamentos de 1888 eram simples caixas de metal, que podiam ser cobertas em couro. O diferencial da Kodak, nesse caso, era a leveza, possibilitada pelo uso de negativos em celulóide. Mas já em fins do século XIX (1898) surge o modelo Folding Pocket, que se tornaria muito popular. Nesse modelo de câmera com acabamento em couro havia um fole extensor para ligar as lentes ao corpo do equipamento. Ao ser fechado, o material transformavase num estojo pequeno, que dispunha de uma alça. A câmera parecia muito mais uma bolsa, um objeto comum, que podia ser carregado facilmente para qualquer lugar. A preocupação com essa função de deslocamento estaria presente também no slogan mais importante utilizado pela empresa até a década de 1910: "Take a kodak with you". 
O problema do deslocamento pode ser evocado até mesmo num sentido metafórico, pois o uso semântico do termo Kodak ultrapassou seu contexto original. Como Nancy West (2000: 22) também destacou, no caso dos EUA, havia de fato, em fins do século XIX, inúmeras empresas que, ao invadir o mercado com seus produtos, acabavam nomeando determinadas ações. A Kodak foi um desses casos e, talvez, o mais exemplar, pois foi utilizada como sinônimo do próprio ato de fotografar, sendo apropriada também como verbo, advérbio e adjetivo em diferentes circunstâncias.

Pode ser também analisada, sobre essa perspectiva, a questão da invasão de privacidade, quando o uso desse tipo de câmera desloca-se de sua função primeira, ser um meio de diversão, e começa a representar ameaça principalmente àqueles que estavam em espaços públicos. De fato, nesse momento, o uso indiscriminado dos equipamentos em locais de lazer ou mesmo na cidade gerava muito mais do que reclamações constantes, pois nos EUA e Alemanha foram, inclusive, criadas leis que visavam regular a prática fotográfica, buscando delimitar os limites e direitos daqueles que tinham sua imagem capturada por um desconhecido. É preciso destacar, no entanto, que havia todo um mercado mais amplo de produção de câmeras denominadas como modelo "Detetive", utilizadas pelo segmento amador que nem sempre dominava as técnicas fotográficas. Por isso, tais questões extrapolavam as implicações do uso da Kodak. É reconhecido, porém, o papel de destaque do material produzido por essa empresa cujos "kodakers" já obtinham lucros quando tiravam fotografias de pessoas ilustres e as publicavam em revistas ilustradas, conforme destaca Meir Weigoder (2003: 356), a respeito do que ocorria nos EUA nos primeiros anos do século XX.

Merecem destaque, ainda, as críticas severas que seriam proferidas por parte dos amadores de elite, em virtude da ampla distribuição desses equipamentos. Afinal, com tantas mudanças ocorridas no campo fotográfico a noção de fotógrafo amador ganhava 
outra significação, passado a estar associada àqueles que desempenhavam a atividade sem ter o domínio da técnica e estética. O médico e fotógrafo amador Albert Londe escreve no Bulletin du Photo-Club de Paris, em 1899, matéria que também foi publicada no Bulletin Belge de Photographie (1889: 535, 26me année, vol. VI), que trata da questão. Para ele havia um "mauvais amateur" e um "bon amateur", facilmente reconhecidos pela relação estabelecida com os equipamentos. O primeiro grupo usava as câmeras sem ter nenhum conhecimento do que havia em seu interior e da técnica laboratorial, sendo autômatos, simples usuários que não podiam propor novidades para o campo. Já o "bon amateur" era a figura clássica reconhecida socialmente nesses países, que haviam sido fundadores de associações, revistas, jornais, enfim, os que tinham visibilidade pública e que exerciam a atividade se afastando de qualquer tipo de uso "familiar" da fotografia.

No Brasil, estando muito longe desse contexto, não havia sequer propagandas da Kodak em revistas nacionais - eram raros os casos que se fazia menção, como a Leitura para todos - existindo certa dependência das publicações estrangeiras na divulgação do equipamento. Entretanto, apesar de não termos nem mesmo dados sobre a importação da Kodak, o fato é que as câmeras tiveram ampla distribuição em nosso país, e, certamente, podiam ser encontradas em lojas que vendiam equipamentos fotográficos que, nesse momento, eram todos importados. É preciso considerar então que esse tipo de restrição não constituiu um limite para a expansão da câmera no Brasil, porém, haveria aqui algumas circunstâncias próprias.

Uma das diferenças principais é que a Kodak estava associada de forma positiva como sinônimo de vida urbana, não havendo uma caracterização específica referida ao universo amador. De maneira geral, as revistas ilustradas iriam fazer essas menções ao uso da Kodak exclusivamente como um registro daqueles que podiam desfrutar dos 
recursos e inovações ocorridas nas cidades. Por exemplo, nas revistas ilustradas cariocas, as que Ana Maria Mauad (1990; 2008) destacou como sendo as mais “mundanas", Fon Fon!, Careta e Revista da Semana, havia colunas específicas que registravam pessoas andando na recém-inaugurada Avenida Central, em muitas situações denominadas como "instantâneos". Isso constituiu um padrão de registro que se popularizou enormemente nesses periódicos.

Mas o termo Kodak se deslocou de seu sentido original, sendo, também, em nosso país, utilizado de maneira livre como verbo ou adjetivo, como aparece na crônica de Gonzaga-Duque Estrada publicada na Kosmos, em 1906, sobre exposição de José Malhoa, ocorrida no Gabinete Português de Leitura. Ali, referindo-se à capacidade desse artista de representar o "typo observado" o autor assim destaca: "E' como se o kodackizasse. E por esse considerável poder retentivo, as suas figuras, quaisquer que sejam ellas, ficam vivas nos quadros" (7/1906, anno III, n. 7; apud Sussekind, 1987: 36).

Esse tipo de alusão estava presente nas publicações de maneiras mais diversas, sendo inclusive apropriado como pseudônimo em colunas publicadas nos jornais. Em Petrópolis, por exemplo, a partir de 1913, o jornal Cidade de Petrópolis publicava em sua primeira página a coluna "instantâneos" assinada por João Serrano, que se intitulava um "Kodac". Era uma coluna social, na qual o autor fazia comentários gerais sobre o que havia ocorrido de mais importante para a elite que vivia ou, simplesmente, veraneava na serra. Essa tendência ocorria também em outras partes do Brasil. No Rio Grande do Sul a "Kodak" era o título de uma revista ilustrada que, curiosamente, não fazia nenhuma menção à fotografia enquanto temática, nem mesmo como a Renascença ou Kosmos. Ao fazer a crônica da vida da elite local, no máximo o que havia eram imagens publicadas desses grupos, como registro e complemento aos textos escritos. 
Flora Sussekind (1987: 37) também destaca esse uso mais amplo do termo Kodak como título de crônicas no Jornal Moderno de 1913, publicado na Bahia. A circunstância seria a mesma: trata-se de textos que celebravam a vida da elite, o cotidiano composto por festas e idas ao cinema. Para a autora, no entanto, a analogia fotográfica iria deixar marcas na própria escrita de tais colunas representadas por frases e parágrafos menores, em "flashes", que objetivam, em sua estrutura, incorporar efeitos de velocidade.

Essas menções, muito comuns na imprensa e até mesmo na literatura do período, revelam a incorporação do vocábulo na linguagem corrente, indicando também o grau de expansão alcançado. O termo Kodak seria apropriado como sinônimo de fotografia no sentido mais amplo, sendo um registro e documento, se distanciando completamente, nessas referências, da especificidade do uso amador. Obviamente, tal difusão não encontrou aqui certos constrangimentos principalmente pelo quadro de ausência da tradição clublística amadora. A primeira associação só surgiu em 1904, como vimos, tendo, no entanto, vida efêmera. Não havia assim um contexto que delimitasse o pólo oposto de uso da fotografia e, por isso, não se delinearia o espaço de disputa, da mesma maneira que nos EUA e países europeus. Destituídos de qualquer preocupação de diferenciar os próprios amadores entre si, o que os membros do Photo-Club esboçaram no Brasil, segundo os textos da Renascença, era a posição distinta em relação ao profissional da fotografia, conforme analisaremos a seguir.

Haveria, no entanto, alusão ao uso desse equipamento pelo fotógrafo amador só que num contexto muito específico. Trata-se do problema da invasão de privacidade nas praias. Ana Maria Mauad (2008: 132) cita uma charge que foi publicada na capa do Jornal do Brasil em 1904, que mostrava várias pessoas - homens, mulheres e crianças usando câmeras Detetive cujo texto era bastante explícito: “[...] É uma praga, ninguém toma banho e todos tiram fotografias! Se uma pessoa se levanta - clic! - ouve-se um 
estalido; se assenta, tem de tomar posição conveniente, porque fica rodeada de objetivas ávidas". Flora Sussekind (1987: 33) também ressaltou, no mesmo sentido, a presença amadora em crítica do próprio Gonzaga-Duque Estrada:

"E o civil já acolhe solícito para impedir que o amador fotógrafo apanhe o instantâneo de uma menina a sair da onda, como lhe exige a rematada patetice do parente vigilante, com melhores razões e em melhor causa arredará do lugar em que houver gente os animais escouceadores que se vestem figurinos da moda".

Esse texto, denominado de "Estética das praias", foi publicado em 1910 em Graves e Frívolos, livro que compilava matérias publicadas na imprensa por Duque Estrada, e que incluía também o artigo sobre a exposição de José Malhoa, referido acima. Por isso, podemos afirmar que ele foi extraído de alguma revista ilustrada dos primeiros anos do século XX. Essa informação é, portanto, relevante pois indica que as revistas constituíam também local para assinalar os problemas ocasionados pelo uso da câmera amadora. No entanto, merecia atenção apenas o espaço das praias, pois não encontraríamos reclamações com o mesmo tom quando se tratava de fotografias produzidas no espaço urbano.

Isso porque na cidade as fotografias instantâneas, publicadas nas revistas ilustradas, eram em parte consentidas, encenadas de alguma maneira, pois as pessoas andavam, mas não ao acaso. A Avenida Central era o lugar da exibição pública e a fotografia consolidava essa visibilidade desejada por parte das elites. Não raro apareciam comentários ressaltando que as pessoas procuravam os fotógrafos para serem registradas, ou melhor, "kodakiadas". Até mesmo João do Rio, em crônica publicada na Gazeta de Notícias de 1908, conta uma pequena história de uma mulher chamada Mme. Figueroa, que havia escondido o rosto para o fotógrafo que tirava registros na rua. Ouvindo o comentário do fotógrafo que daquela maneira a imagem sairia escura, a 
mulher não hesitou e pediu que repetisse a fotografia, e [...] ficou de pé numa pose de ave real enquanto o moço louro a kodakiava" (apud Souza, 2004: 48).

O problema da artificialidade das fotografias instantâneas integraria as próprias revistas ilustradas, sendo enfatizado o sentido cômico desse tipo de imagem construída e, de alguma forma, transformada em clichê. A Revista da Semana, por exemplo, publicou uma charge denominada "Photo-Instantaneo", em que o fotógrafo dirige a cena da pessoa andando na rua. A legenda confirma a intenção em disfarçar os sinais de encenação: "Tome assim um ar de quem vae distrahido e não me vê pela frente..." $(8 / 5 / 1910$, n. 521)

Nesse contexto, o sentido amador da Kodak se distanciava completamente do uso corrente. O trabalho de documentar a vida na cidade estaria associado ao equipamento que estava descontextualizado de sua destinação original. Havia, de fato, reconhecimento e mesmo exaltação desse novo campo de trabalho para o fotógrafo, como é indicado na revista Fon Fon! de 1907. Ali o texto é bem explícito sobre a relação de inversão, disseminação no campo profissional, que a Kodak iria ter no Brasil: "Goza magnificamente a vida, trabalha passeando, divertindo-se. Engatilha a Kodak e percorre as avenidas fotografando as elegâncias que passam [...]" (apud Pereira, 2004: 104). O título da coluna já era bastante elucidativo, "Hábitos da elite carioca". Portanto, a câmera amadora teria, em nosso país, acentuada repercussão num momento de também mudanças urbanas com a Reforma Passos, circunstância muito apropriada para a ampla disseminação da fotografia que podia ser realizada por esse tipo de câmera. 


\section{O amador e o profissional}

A importância e complexidade desta questão exige que ela seja retomada no capítulo final. Constam aqui elementos introdutórios indispensáveis para a caracterização inicial da "cultura amadora" que estamos estudando.

É preciso considerar que as polarizações entre amadores e profissionais são encontradas já nos manuais de fotografia mais antigos. Grace Seiberling (1986: 18) nos mostra que essas questões estavam presentes desde o início da difusão da fotografia na Inglaterra, na década de 1860, quando há profissionalização da atividade fotográfica com a popularização dos retratos em formato carte de visite. Mas ali o terreno estava definido: o amador provinha das mais altas classes sociais, tinha cultura artística e técnica, sendo inventor de novos processos. Um exemplo claro seria Talbot, que dominava diversas áreas do conhecimento, sendo cientista, fotógrafo e especialista em assiriologia, um dos mais importantes da Inglaterra daquele momento.

Isso seria alterado com as mudanças técnicas, sobretudo da década de 1880, que contribuíram para a inclusão, na atividade fotográfica, de grandes contingentes provenientes das "classes médias" e o surgimento de clubes específicos que valorizariam acentuadamente a dimensão artística da prática. Além disso, havia a enorme expansão de equipamentos como a Kodak, que introduziam nesse cenário, outra relação com a fotografia. Dentro desse contexto, surgem questionamentos de toda ordem, afinal qual seria a definição do amador? Discutia-se inclusive sobre a necessidade de criar outra denominação. Um quadro de luta simbólica de grupos que não queriam perder o espaço de distinção já reconhecido socialmente.

Os clubes de fotografia também se diferenciavam entre si, apesar de terem pontos em comum. Em certas situações havia caracterizações explícitas como os amadores que defendiam intervenções na imagem; outros professavam a associação 
com a visão ocular, para que a fotografia tivesse apenas efeitos visuais - sem alterações significativas e necessidade de imitar técnicas da pintura (Sternberger, 2001: 57; Joschke, 2005: 218). Também havia aqueles dos excursionistas, mais interessados no uso da fotografia como curiosidade visual associado ao interesse científico (Poivert, 2001: 18; Gunning, 2001: 88). Em geral todos esses grupos criticavam os usuários de câmeras como a Kodak.

Nesse contexto de muitas dicotomias surgia mais acirradamente a necessidade de diferenciar os campos, dos amadores entre si, e em relação aos profissionais. $\mathrm{Na}$ revista Paris-Photographe, há várias menções à questão. Como aparece no periódico, numa das reuniões da Union Internationale de Photographie ${ }^{29}$, um de seus membros, o próprio amador Maurice Bucquet citado anteriormente, sugere para o grupo que era necessário encontrar uma "définition" do que se entendia ser o "profissionel" e “amateur” (20/9/1893: 393, 3e. année, n. 9). Tal proposição é rejeitada, mas devido à importância da questão, num dos números seguintes da revista, Anthonny Guerronnan ${ }^{30}$ escreve o artigo "Amateurs photographes ou profissionnels?" (30/9/1893: 484-85, 3e année, n. 11). O autor considerava que os amadores dispunham de tempo e capital necessários para se dedicar a prática e, por isso, suas fotos podiam ser, em determinados casos, melhores que as dos profissionais. Porém, era muito mais importante para Guerronnan a distinção estar relacionada às aplicações da imagem e não ao produtor. Como exemplo cita os conjuntos propostos por Leon Vidal para a futura Exposição Universal de 1900: "photographie artistique, applications à la science, applications à l'industrie, puis le matériel, etc." (Ibid.). Guerronnan lembra que se a nomeação dessas categorias tivesse que ser realizada literalmente, haveria diferenças entre os próprios

\footnotetext{
${ }^{29}$ A Union Internationale de Photographie foi fundada em 1891 por membros de sociedades fotográficas situadas em diversos países europeus.

${ }^{30}$ Foi também autor do Dictionnaire synonymique français, allemand, anglais, italien et latin des mots techniques et scientifique employés en Photographie. Paris: 1895.
} 
amadores que deveriam ser consideradas, pois alguns deles já não utilizavam as melhores câmeras e materiais. Um problema que levaria a uma infinita criação de termos que não teria nenhuma conseqüência prática.

Podemos dizer que a proposição de Maurice Bucquet é representativa da divisão que iria ocorrer dentro do próprio grupo de amadores. O Photo-Club de Paris acabava de ser fundado e promovia neste mesmo ano, em 1893, a primeira exposição artística, lançando os preceitos estéticos que seriam muito utilizados como atributos de diferenciação entre a produção amadora e a profissional. Os membros da revista ParisPhotographe e da própria Union, locais em que conviviam diferentes vertentes, não compartilhavam, porém, desses postulados, conforme fica expresso na opinião contrária à proposição de Bucquet. Aliás, essa polarização se expressará naquilo que Michel Poivert (2001: 19) denomina ser a diferença entre amadores dos clubes ligados à atividade artística e aqueles que uniam interesse científico e fotografia, que passaram a integrar os clubes de excursionistas.

Mas aqui preponderavam as premissas do Photo-Club de Paris. Não havia outros espaços cujos interesses fossem conflitantes, onde pudessem surgir as divergências encontradas na França. Por isso, já na segunda exposição do Photo-Club do Rio de Janeiro, em 1905, há preocupação em delimitar o clube como um lugar para o público amador, conforme destaca logo no início do artigo, Von. Ab. Eff.

"Era de amadores (para não falar de artistas-mestres) quer dizer, de occupados em outros misteres, mas que realizam o milagre da perfeição da Arte, para que vivem, com mais nobreza, do que, talvez, os profissionaes, que della vivem.

Fixar uma imagem pelos processos photographicos, sem outro interesse que o de alimentar o enamorado ideal, sem proventos materiaes para o eu, num século e numa terra em que o egoísmo é a philosophia da multidão, e estas cousas de sciencia pura, de arte pura, de letras puras são entrevistas com requintado desamor e ares de mofa, cultivar em taes condições a photographia é merecer dos que se dedicam conscientemente com essas manifestações artísticas os mais fortes estimulos e as mais legitimas homenagens" (9/1905: 68, anno II, n. 19). 
É interessante notar que a menção direta à presença amadora no clube ocorreu na exposição em que começaram a participar profissionais. No próprio artigo, foi impresso em página individual um retrato tirado por Luiz Musso, conhecido retratista do Rio de Janeiro. Mas apesar dessa inclusão, ao final, o autor se posiciona diretamente em relação ao problema da diferenciação:

"Escapam aos intuitos artisticos do Club as reproduções de Candrelier e os trabalhos dos profissionaes, porque nestes o clichê é preparado por um, manipulado por outro, retocado por terceiro, a prova impressa e revelada ou virada por officiaes differentes ...colorida por extranho (Ibid: 101).

O amador seria, nessa perspectiva, responsável por todas as fases do processo fotográfico e, por isso, suas obras representariam muito mais o esforço individual, trazendo como conseqüência a marca do autor. Mas só na terceira exposição do clube em 1907 é que o título do artigo inclui a nomeação "artística". Uma denominação que servia não apenas para promover a diferenciação dos amadores dentro do campo, mas, sobretudo, para colocá-los em posição de vantagem em relação aos profissionais. Aliás, aqui participou, mais uma vez, Luiz Musso e ainda Augusto Malta.

O argumento de que os profissionais não são responsáveis por todas as etapas na realização de suas fotografias permanece, mesmo sendo reconhecida a qualidade de suas imagens. Para Álvaro de Lima, Musso dominava os processos artísticos, porém ainda assim é criticado:

"[...] Outro artista fora de concurso e que maneja o carvão a transporte é o Sr. Musso; do quadro em que nos apresentou alguns dos admiráveis retratos feitos no seu atelier nada podemos dizer senão bem; é certo que os profissionaes em geral não podem ter a preocupação do trabalho artístico porque não procuram a satisfação de um ideal, senão um meio de vida; de mais o resultado final desse trabalho - a prova prompta, representa o esforço de meia dúzia de operários que, a não ser o operador da galeria, não conhecem o modelo: este revela, aquelle retoca, aquell'outro imprime, um quarto retoca a prova. 
E evidente que esse trabalho está longe de ser uma obra de arte, entretanto o Sr. Musso consegue retratos admiráveis de semelhanças e de tonalidade agradabilíssima" (11/1907: 253, anno IV, n. 45).

Até Augusto Malta recebeu críticas. Da mesma forma que Musso, ele teve seu reconhecimento na exposição e no artigo, ganhou o "prêmio de profissional" e há uma fotografia de sua autoria publicada na matéria. Álvaro de Lima reconhece ainda que Malta era muito hábil na ampliação e teve papel importante na documentação das mudanças ocorridas no Rio de Janeiro com o prefeito Pereira Passos, pois "tomou nota de tudo, photographou tudo, sempre com mão de mestre" (Ibid.: 255).

Mas seria um artista fotógrafo? Para não deixar dúvidas, Álvaro de Lima faz em seguida um comentário sobre o "Museu de documentos photographicos", que o clube pretendia organizar, tendo em Malta possivelmente um grande contribuidor. Não temos nenhuma referência posterior sobre a existência de tal museu, porém, é importante destacar essa menção, pois os membros do clube fazem aqui explicitamente a distinção entre o amador como sendo "artista" e o profissional como aquele que estava associado apenas à fotografia documental. Nada melhor do que Malta para simbolizar esse modelo, que tinha sua importância reconhecida em outros lugares que não o Photo-Club do Rio de Janeiro. Por isso, o texto segue com as críticas, que se transformam inclusive num conselho:

"Diremos apenas ao ilustre profissional que procure melhor o tom da prova quando tiver de fazer retoques nos céos; não descuide esse pormenor que é importante" (Ibid.).

A representação das nuvens era uma temática muito comum para esse debate e está inclusive no texto de Deiró, publicado na revista Kosmos. Segundo esse autor quando se fotografa o "céo" azul, o resultado na imagem se aproxima do branco num 
"tom assaz forte". Era preciso fazer alterações no laboratório ou na exposição da fotografia para que o resultado final não ficasse numa quase tradução da natureza, sem contrastes, cumprindo a função apenas de "inventário" (11/1904, anno 1, n. 11) .

Já Álvaro de Lima utiliza a temática em referência às obras de Augusto Malta. Porém, na fotografia desse profissional, escolhida para integrar o artigo, encontramos contrastes na representação das nuvens, que estão muito próximas àquelas normas estéticas vigentes. O céu do "Effeito da ressaca na Avenida" está cheio de gradações tonais, que se confunde com o próprio mar revolto. Mas mesmo assim a crítica se direciona ao detalhe, ao problema do retoque, sendo significativa desse movimento em que fomentar a polêmica entre amadores e profissionais podia ser muito mais importante do que haver de fato algum motivo concreto.

Porém, nesse contexto de disputa, em que compartilhava-se de convenções e normas, o que o Photo-Club do Rio de Janeiro promoveu para tal debate foi mais circunscrito do que ocorria no Exterior. As repercussões aqui seriam meramente pontuais e não serviriam para marcar a diferença existente entre os próprios amadores, como no caso já referido da Kodak. Alberto de Sampaio também responde ao problema, a identidade como fotógrafo amador para ele era importante. Tinha também interesses culturais amplos, pois se dedicou a outras atividades. Mas estava integrado em outro espaço social. Morava em Petrópolis e não no Rio de Janeiro. Na cidade serrana, o problema da distinção amadora terá outros ingredientes, como trataremos no próximo capítulo. 


\section{CAPÍTULO 3. ALBERTO DE SAMPAIO}

\section{A personagem}

Alberto de Sampaio (1870-1931) era advogado e fotógrafo amador, duas atividades que foram desenvolvidas de forma paralela. Nasceu no Rio de Janeiro e lá se formou em 1892 pela Faculdade Livre de Ciências Jurídicas e Sociais. Pertencia às elites urbanas da segunda metade do século XIX. Era filho único do advogado Bento Pinto Ribeiro Pereira de Sampaio (1836-1908) e Luiza Machado Coelho de Castro (?1875), e estava inserido num núcleo familiar que circulava nas mais altas camadas sociais de seu tempo. Era neto, por parte materna, de José Machado Coelho de Castro (?-1896), que fora diretor de diversas instituições e empreendimentos do período, como o Banco do Brasil e também da Estrada União e Indústria, construída por Mariano Procópio Ferreira Laje - que ligava Petrópolis à Juiz de Fora. Já pelo lado paterno tinha como avô Manuel Pinto Ribeiro Pereira de Sampaio (1780-1857), que teve carreira expressiva no Império. Exerceu vários cargos como Veador da Casa Imperial (1855), Presidente do Tribunal da Relação (1839 e 1841) e, ao final da carreira, foi Presidente do Superior Tribunal de Justiça (1842 e 1856). Como essa trajetória fora considerada relevante pelo próprio Alberto de Sampaio, ele escreve uma pequena biografia da vida profissional desse avô.

O eixo Rio de Janeiro-Juiz de Fora seria importante, pois Bento Sampaio cuidou dos negócios da família Laje durante muitos anos, inclusive após a morte de Mariano 
Procópio $^{31}$. Mas com o falecimento precoce da mãe de Alberto de Sampaio, em 1875, não sabemos se ele permanece no Rio de Janeiro, na casa da família no bairro do Rio Comprido. Há apenas indicação de que estudou no Colégio Paixão em Petrópolis, situado no mesmo bairro em que seu pai compra um terreno em 1887 e ali constrói uma pequena casa. Essa moradia foi ampliada por Alberto de Sampaio após o casamento com Cecília Teixeira Soares em 1895.

Em Petrópolis nasceram seus oito filhos: Álvaro (1896-1974); João (1897-1964); Bento Luiz (1899-1978); Alberto (1902-1977); Luiza (1903-1999); Eduardo (19051958); Zulmira (1909-1923) e Maria Helena (1920-1970). O casamento desempenhou também papel central em sua vida profissional, pois Sampaio trabalhou em diversos empreendimentos que tinham atuação direta de seu sogro, o engenheiro e construtor de estradas de ferro João Teixeira Soares ${ }^{32}$. Por isso a sua extensa participação em empresas ligadas a esse ramo. Sampaio trabalhou na Estrada de Ferro Peçanha-Araxá, na Cia. Estrada de Ferro Victória-Minas e na Itabira Iron Ore Company. Foi ainda empresário, tendo sido sócio da Cia. Mineira de Mineração e da transportadora de minério Lellis e Cia. No início da carreira foi promotor público em Petrópolis e suplente de Juiz Federal, ambos em 1896. Nesse período, anunciava no Almanak Laemmert e jornais de Petrópolis como advogado, sendo o endereço sua própria residência.

\footnotetext{
${ }^{31}$ Mariano Procópio Ferreira Laje e sua irmã, Mariana Barbosa de Assis, foram casados com os irmãos do avô de Alberto de Sampaio (José Machado Coelho de Castro): Mariano P. Ferreira Laje com Maria Amália Machado Coelho; Mariana Barbosa de Assis com Constantino Machado Coelho e, depois que ficou viúva, com Manoel Machado Coelho. Quando Mariano Procópio Ferreira Laje faleceu em 1872, Bento Sampaio (advogado e pai de Alberto) cuidou a partir de então dos negócios da família. Por isso, há no acervo Alberto de Sampaio documentos pessoais como compras de terrenos, fotografias e notas de diversas procedências relacionados aos Laje (Pereira, 2004:.41).

${ }^{32}$ A carreira de João Teixeira Soares foi notável: participou da construção da Estrada de Ferro Corcovado junto a Pereira Passos, foi inclusive um dos chefes do grupo Farquhar - presidido por Percival Farquhar, que criou a Itabira Iron Ore Company, dentre muitos outros empreendimentos. Gozava de muito prestígio e como indicam os jornais de Petrópolis recebia visitantes ilustres em suas fazendas situadas no Vale do Paraíba. Essa associação com as esferas do poder se manifestava também na participação em outras obras de expressão, como a primeira fase da demolição do Morro do Castelo, no Rio de Janeiro, que Teixeira Soares realiza em 1921 com uma firma que tinha já a participação de dois filhos de Alberto de Sampaio, recém-formados em engenharia (Ibid.: 45).
} 
Alberto de Sampaio provinha de uma família de advogados e exerceu essa mesma profissão. Escrevia também em jornais sobre temas associados à sua atividade profissional, abordando questões ligadas à construção de estradas de ferro e exploração de minério. Conhecia detalhadamente aspectos técnicos como bitolas, fabricantes de locomotivas, etc. Seus interesses, no entanto, iam além das atividades profissionais. Podemos dizer que sua maior dedicação e empenho fora à fotografia, que, de fato, constituiu mais do que um simples hobby. Havia uma identidade amadora, compartilhada socialmente, como vimos, em que o domínio técnico seria apenas um de seus componentes.

Mas se há preponderância da fotografia, Sampaio também teve seus momentos de dedicação a outras áreas ligadas ao campo artístico. Da década de 1890 temos um caderno de poesias com o pseudônimo de "Alpha" - que ele adotava nesse período em outros textos publicados. Há ainda um romance inacabado, uma peça de teatro que se passa no Rio de Janeiro e matérias sobre assuntos variados como moedas e viajantes.

Os livros que ainda hoje integram o que foi sua biblioteca pessoal expressam claramente todos esses amplos interesses. Há publicações de direito, história da arte, literatura e fotografia. Além disso, Sampaio desenhava e pintava quadros a aquarela, que serviam como decoração em sua residência. E ainda se dedicou nos primeiros anos do século XX à coleção de cartões postais.

\section{Petrópolis/Rio de Janeiro ${ }^{33}$}

A Petrópolis da passagem do século XIX para o XX, conhecida como cidade de veraneio da corte imperial, era local de residência temporária de grupos privilegiados que viviam na capital do país. Lugar da "realização possível da fantasia europeizante"

\footnotetext{
33 A pesquisa se baseou, principalmente, nos jornais da cidade: Tribuna de Petrópolis, Gazeta de
} Petrópolis e $O$ mercantil. 
nas palavras de Jeffrey Needell (1993: 178) ou solução para o "sanitarismo urbanístico" como se refere Luis Felipe de Alencastro (1997: 68). Petrópolis era então um refúgio para as epidemias que ocorriam no Rio de Janeiro e, ao mesmo tempo, local onde as elites se esforçavam por manter a cidade de forma idealizada distante das contradições de nossa sociedade, que se evidenciavam na capital do país.

Com a República, a cidade teve crescimento considerável por duas razões principais: a primeira é o fato de Petrópolis ter sido a capital do estado do Rio de Janeiro entre 1894-1902. Nesse período foram realizadas diversas obras de infraestrutura como calçamentos, instalação de rede de esgotos, iluminação, abastecimento de água, etc. Surgiram também novas construções, muitas delas foram erguidas “com os recursos provenientes da época do ensilhamento, pela avalanche de argentários que se transportaram a Petrópolis nos verões de 1890 e 1891 ".34

Há indicações de que a partir de 1903, com Petrópolis deixando de ser a capital do estado - que voltara para Niterói - a cidade entra numa grave crise financeira já iniciada nos últimos anos do século XIX. A Prefeitura tinha pouco dinheiro, mas a cidade continuava gozar do mesmo prestígio social e abrigava diversas "legações", que eram representações oficiais do corpo diplomático da Áustria, Alemanha, Japão, México, Argentina, Chile, Guatemala, Uruguai e, ainda, a embaixada dos EUA, sendo a residência oficial dos diplomatas.

Paralelamente, ocorria a reforma Pereira Passos no Rio de Janeiro. A capital do país se modernizava, situação que deixou seus reflexos na cidade serrana. Houve então diversos movimentos em torno da vida social e política que, diferentemente do Rio de Janeiro, tinha participação expressiva da população lá residente. Nesse contexto,

\footnotetext{
${ }^{34}$ Artigo do jornal $O$ Paiz de 1910, também publicado na Tribuna de Petrópolis (4/8/1910). De fato, segundo os dados dos arquivos históricos da Prefeitura, houve incremento no pedido de aprovação de projetos residenciais na década de 1890, e a maior parte deles seria construída.
} 
destacamos duas questões principais: a primeira é que Petrópolis não era só o lugar de veraneio das elites, mas também espaço de consolidação de uma determinada imagem pública, onde esses grupos queriam ser auto-representados e tinham participação ativa nesse processo. Em segundo lugar, devido a essa conjuntura, podemos dizer que havia na cidade interseções de forma exacerbada entre a vida privada e a pública. Tal situação se expressava de maneira contundente no movimento para anexar Petrópolis ao Rio de Janeiro, na importância dos clubes sociais, e, por último, no papel desempenhado pelos jornais e publicações da cidade, que conferiam visibilidade às ações.

O movimento para anexar Petrópolis ao Rio de Janeiro surge ainda em 1902, numa proposta apresentada por Quintino Bocayuva, prefeito do Distrito Federal, na Assembléia Legislativa. Apesar de não ter tido sucesso, esse projeto continuou a ser referido nos anos seguintes. Em 1904, formou-se um grupo integrado por Roxo de Rodrigues, Souza Leão, Eugênio Gudin, Barão de Santa Margarida, José Paranaguá e o sogro de Alberto de Sampaio, João Teixeira Soares. O debate sobre a anexação de Petrópolis ressurgiria ainda em 1906 quando o próprio Roxo de Rodrigues levou novamente a proposta para o prefeito do município. Parte do texto apresentado foi publicado no jornal Tribuna de Petrópolis (15/2/1906) e ali há um comentário significativo, pois ressalta a necessidade de manter a distinção de Petrópolis em relação às demais cidades do estado e mesmo bairros do Rio de Janeiro: "Petrópolis não deve perder de um momento para outro os foros de que goza para se converter num simples subúrbio daquelle Districto, abandonado sem melhoramentos úteis como acontece actualmente com o Engenho Novo, Todos os Santos, Cascadura e muitos outros”.

Esse seria um discurso que estaria incorporado em diversas circunstâncias e que teve seu papel na mobilização desses grupos em outras esferas, como a dos clubes sociais. Lá cada grupo tinha a sua própria agremiação. Os imigrantes alemães, por 
exemplo, contavam com o Sangerbund Eintracht, Turnverein Petrópolis, Hamonie Mosethal e Deutscher Verein. Já os italianos tinham a Societá Operaia Italiana Vittorio Emannuele III. E ainda havia o Club Róseo, Club Familliar Estrela do Oriente, Club Recreativo Familiar de Petrópolis, Club M. Leopoldo Miguez e a Sociedade Dançante e Beneficente Primeiro de Maio, dentre muitos outros.

No entanto, havia os clubes freqüentados pelas elites que eram o "centro das rodas elegantes" como eles mesmos se referiam (Tribuna de Petrópolis, 21/4/1906). Os de corrida de cavalos, Jockey Club e Derby Club e, ainda, os principais de sociabilização, Club Petrópolis e Club dos Diários, que agregavam personalidades com papel expressivo também na política nacional, situação que seus integrantes sabiam tirar proveito. Por exemplo, todo o grupo acima citado, que participava do movimento de anexação de Petrópolis ao Rio de Janeiro, pertencia ao Club dos Diários, sendo inclusive parte de seus membros honorários. Portanto, tal projeto expressava muito mais os anseios dos Diários do que da população da cidade ou mesmo do poder público.

Fundado em 1895, o Club dos Diários tinha esse nome, como o próprio Jeffrey Needell (1993: 95) se refere, devido à ida "diária" de muitos de seus integrantes, de Petrópolis para o Rio de Janeiro. A viagem de trem durava, inicialmente, cerca de seis horas e, depois, em fins do século XIX, já seria encurtada para cinco horas. Mas tanto os Diários como o Petrópolis tinham sede na serra e no Rio de Janeiro: o primeiro ocupava o antigo prédio do Cassino Fluminense no Passeio Público e, o segundo, passou a ter um andar no edifício do jornal O Paiz, na recém inaugurada Avenida Central.

São clubes da República que substituíram antigas associações de prestígio, como o Cassino Fluminense (que também manteve sua sede em Petrópolis e reunia as personalidades mais importantes do período imperial). A situação havia mudado, porém, como ainda ressaltou Jeffrey Needell (Ibid: 97), em termos simbólicos e 
materiais, havia muitas continuidades, afinal os integrantes dos novos clubes eram praticamente os mesmos do antigo Cassino, cujos títulos de nobreza não deixaram de ser demonstrados. Havia apenas uma transição em termos econômicos, que podia ser observada através das gerações dessas famílias, como destaca o autor. Isso significa que a antiga riqueza proveniente do café "fluminense", que se encontrava em decadência, era substituída por ocupações urbanas dos membros que se orgulhavam de pertencer agora a um $C l u b$, conforme eram referidas tais associações nos países europeus.

Como eram constituídos pelos mesmos grupos, em 1906 ocorre uma grande fusão, tendo os Diários incorporado o Club Petrópolis e depois outros, como o antigo Cassino Fluminense e o Jockey Club, transformando-se assim na associação de elite mais importante de seu período, tanto no Rio de Janeiro, como em Petrópolis. Em torno desse clube seriam desenvolvidas as principais estratégias para promover a vida social e cultural na cidade serrana. Eles arrecadavam dinheiro, alugavam espaços para os eventos, e, ainda, eram responsáveis por divulgar os acontecimentos na imprensa da cidade e do Rio.

O centro da mobilização era o "Verão em Petrópolis", como se denominava o período de veraneio na cidade, momento em que ocorriam todos os eventos sociais mais significativos, organizados a partir de 1904. O período da vilegiatura começava em dezembro, se estendendo até abril do ano seguinte. Havia então festas privadas nas residências de diplomatas e figuras importantes, e, no âmbito público, tínhamos matinês, bailes à fantasia, apresentações musicais, conferências literárias, exposições de pintura e exibição de filmes. E não eram poupados esforços para trazer o que eles consideravam como sendo o melhor da vida cultural carioca.

Os membros do clube se empenhavam enormemente nesta organização, tendo arrendado por quase duas décadas o edifício do Palácio de Cristal. A mobilização era 
grande e envolvia divulgação de listas de casas a serem alugadas fornecidas pelos próprios moradores (que ficavam disponíveis em lojas no Rio e em Petrópolis) mudanças no horário dos trens para permitir idas a capital do país, criação de linhas especiais de transporte em Petrópolis para facilitar o acesso a festas que acabam de madrugada, enfim, diversos recursos organizados por iniciativa particular.

As conferências literárias eram um dos pontos mais altos da festa e demonstram claramente o esforço por prover a serra de vida cultural representativa. Desfilavam nos salões desses clubes autores reconhecidos como João do Rio e Olavo Bilac, Elysio de Carvalho, Medeiros de Albuquerque, outros que vinham do mundo diplomático como Alcebíades Peçanha (irmão de Nilo Peçanha, Presidente da República de 1909-1910), e moradores da cidade, como o jornalista Conde de Afonso Celso. Os temas eram representativos dos interesses genéricos dessa elite como "Flirt" e "Da expressão na arte". Era preciso, no entanto, encontrar espaço que ia além da cidade serrana. Por isso as conferências eram publicadas em parte nos jornais locais e algumas delas de forma integral na revista ilustrada Kosmos.

A Renascença trazia também matérias sobre os eventos ocorridos, como em 1905 em que há comentários sobre as atividades musicais; "Quanto a vida artística nacional, parece ter-se refugiado em Petrópolis" (2/1905: 78, anno II, n. 12). Havia se apresentado num único domingo nada menos do que Alberto Nepomuceno, Magdalena Tagliaferro (ainda com 11 anos) e o maestro Henrique Oswald, nas sedes do Club dos Diários e Cassino Fluminense. Por isso, certo tom de lamento se repetia em comentários posteriores:

"Vemo-nos mais uma vez obrigados a recorrer a Petrópolis para ter alguma coisa a dizer sobre o movimento artístico musical.

Os concertos alli naquela pitoresca cidade serrana se tem sucedido com uma freqüência invejável e uma constância que realmente é para admirar" (3/1905: 127, anno II, n. 13). 
Os clubes, no entanto, interferiam não somente na vida social, mas também no espaço público, promovendo obras de melhoramentos. Por exemplo, o Diários foi responsável pela construção de um coreto na área central (na praça da Liberdade), organizava festas para arrecadar dinheiro para obras como a finalização de uma igreja situada num bairro em que vários de seus membros residiam (Igreja de Santo Antônio), etc. É preciso, portanto, considerar que nesses anos não havia nada na cidade que pudesse ocorrer sem contar com alguma ajuda particular, no caso, os clubes de elite. Até mesmo na ocasião do primeiro calçamento em macadame realizado em diversas ruas, em 1905, foi preciso que um morador, Domingos de Souza Nogueira, cedesse um de seus terrenos para abrigar os equipamentos (Tribuna de Petrópolis, 2/12/1905).

A interferência da esfera privada na vida pública pode ser evidenciada, também, pela importância e forma com que as publicações locais eram mobilizadas. Entre 18981906, como destacam Marcelo e Cybelle de Ipanema (1989: 40), foram produzidas 54 publicações ao total, entre revistas e jornais. Os autores mostram que mesmo em relação ao Rio de Janeiro esse número era expressivo. A alta produção de materiais impressos estava voltada para a cobertura do que ocorria na cidade, incluindo, em suas matérias, crônicas de escritores renomados, como Machado de Assis ou jornalistas que escreviam na imprensa carioca, como o já referido Conde de Afonso Celso e Osório Duque Estrada.

Entre os jornais a Tribuna de Petrópolis, fundada em 1902, como ressalta Luciana D'Avilla (2005: 70), tinha perfil mais comercial, que se traduzia pela variedade de assuntos abordados. A Tribuna dava também atenção especial para os acontecimentos locais, desde a cobertura da vida diplomática às festas particulares, trazendo relatos do que havia ocorrido. Serão nessas páginas que ficaria altamente 
evidenciado de que forma se interceptavam a vida pública e privada das elites daquela cidade.

Mas, afinal, que tipo de privacidade era essa que podia ser estampada nos jornais? Podemos dizer que, por um lado, havia a dimensão pública da vida privada em espaços de sociabilidade constituídos pelos clubes, residências particulares e hotéis. Nesses locais, havia encontros que eram relatados em detalhes, publicava-se até o cardápio servido nos jantares. Além disso, encontramos listas intermináveis divulgadas na primeira página do jornal Tribuna de Petrópolis, que identificava quem havia participado de cada evento, mesmo na ocasião de enterros. Tal exposição era calculada e, de certa forma, fazia parte do jogo social. É possível dizer que para ser considerado importante não apenas dentro da pequena sociedade petropolitana, mas, por extensão, na capital do país, era preciso estar integrado à cidade serrana e, de alguma forma, ter seu nome mencionado na imprensa local. Desta maneira, seja na ocasião de reuniões realizadas na casa do Barão do Rio Branco, em festas de despedida de diplomatas que retornavam ao seu país de origem, na indicação de quem havia subido para passar o verão e, principalmente, na visita de estrangeiros que vinham cumprir alguma missão política no Brasil e apenas passeavam em Petrópolis, havia a necessidade de se mencionar o nome dos participantes, ou, pelo menos, fazer referência às famílias que lá estiveram presentes.

Por outro lado, havia momentos em que o equilíbrio desse jogo social, composto de espaços consentidos para serem adentrados pela imprensa, entrava em desequilíbrio. E aí, em algumas situações, apareciam notícias que fugiam do padrão. Uma delas merece destaque. Francisco $\operatorname{Santos}^{35}$, um ator de teatro de origem portuguesa, dono da Companhia Dramática Portuguesa, que mais tarde se tornará um dos pioneiros do

${ }^{35}$ Francisco Santos mudou-se para Pelotas (RS) na década de 1910. Lá tinha uma sala de cinema; produziu, filmou e atuou em diversos filmes. É dele o mais antigo filme de ficção preservado no Brasil, $O$ óculos do vovô, de 1913 (Santos, 1995). 
cinema no Brasil, esteve em Petrópolis em 1908 e apresentou algumas peças, dentre elas "Um verão em Petrópolis". Todos os trabalhos encontravam-se "devidamente ensaiados" como anunciava a propaganda (Tribuna de Petrópolis, 7/4/1908). Porém, no dia seguinte à estréia de sua companhia aparece o seguinte reclame:

Constando-me por intermédio de alguém, que, na peça com o título acima que hoje sobe à scena no Theatro Floresta na qual são tratados assumptos de palpitante actualidade de Petrópolis, pretende-se fazer espírito com minha pessoa e alguns amigos meus, previno que logo á noite irei assistir ao espetáculo, e protestarei, desde logo se a crítica ultrapassar os limites do bom tom.

Petrópolis, 7 de maio de 1908.

Um Petropolitano.

É possível supor que esse informe tenha sido produzido pelo próprio grupo teatral, já que nas notícias das seções anteriores, das outras peças, sempre havia a referência a poucos espectadores. No entanto, mesmo que isso tenha ocorrido é interessante observar o recurso utilizado, ao indicar que a vida particular de um morador poderia ser assunto da peça teatral. Tal intermediação entre a vida política, social, artística e mundana das elites aparece em outros artigos do próprio jornal Tribuna de Petrópolis. Há um relato, por exemplo, da frustrada fuga de um jovem, para o Rio de Janeiro, com uma mulher casada. Encontramos também uma crônica escrita como um diálogo entre dois jornalistas locais, que fazem comentários e críticas sobre as próprias colunas recém publicadas, cobrindo festas no Club dos Diários e recepções particulares, etc.

Dentro desse contexto, foram criados dois circuitos muito representativos da interferência dessa elite na cidade: o primeiro se refere às exposições artísticas e o segundo está associado à expansão do cinema.

Trataremos inicialmente da constituição de espaços para exposições de pinturas organizadas pelo Club Petrópolis em 1904, 1905 e 1906, que ocupavam papel central 
nas festividades do "Verão em Petrópolis", organizadas no encerramento dos eventos. Os membros desse clube, liderados por Roxo de Rodrigues atraíam para a cidade os artistas mais importantes do período, como Henrique Bernadelli, João Baptista da Costa, Modesto Brocos, Insley Pacheco, Pedro Peres (Pedro José Pinto Peres, que, possivelmente, participou do Photo-Club do Rio de Janeiro), Ernesto Papf, Roberto Mendes, Belmiro de Almeida, Augusto Girardet e as irmãs Ana e Maria da Cunha Vasco, dentre muitos outros.

Com todos esses esforços empreendidos, pelo menos no que se refere à criação de um circuito artístico, Petrópolis se igualaria ao Rio de Janeiro. Mas não foi o que aconteceu, pois nestas exposições, diferentemente do que ocorria no Rio, admitiam-se também muitos amadores. Em 1904, segundo uma longa matéria divulgada na revista Renascença, de autoria do diplomata que residia em Petrópolis, Domício da Gama, havia uma diferença importante. Para ele, apesar de ter sido "uma vilegiatura de quadros" e "experiência de descentralização artística", as pinturas ali apresentadas eram estudos e, portanto, estavam inacabadas (4/1904, anno 1, n.2). A exposição não teria assim a mesma importância que os salões oficiais da Escola Nacional de Belas Artes. Porém, ele mesmo destaca o elevado número de quadros vendidos e diz que os visitantes não estavam preocupados com os trabalhos "terminados". Havia um público menos exigente, mas que, em compensação, eram potenciais consumidores.

Desta maneira, o estabelecimento de um circuito comercial para as obras de arte, integraria indiretamente as estratégias do clube, não apenas na promoção de um campo artístico na cidade, mas, sobretudo, para poder, de alguma forma, diferenciar esse espaço da capital do país. Por isso, o próprio Club Petrópolis também adquiria pinturas que podiam ser doadas ou servir como decoração na sede do estabelecimento. Em 1906, 
compraram o quadro "As rosas" de João Baptista da Costa e doaram a Cecília, esposa de Alberto de Sampaio, que era membro do clube (Tribuna de Petrópolis, 13/3/1906).

É preciso ressaltar, também, que a importância dessas exposições, dentro daquele contexto social (de uma cidade provinciana e, ao mesmo tempo, com ares de cosmopolita), era muito maior do que no Rio de Janeiro. Por um lado, temos certa autonomia, pois as exposições ocorriam de forma independente de instituições oficiais destinadas ao ensino artístico e, por outro, o espaço era totalmente capitaneado pelos grupos que as organizavam, havendo maiores interferências das esferas do poder. Houve uma exposição que contava com a presença do Presidente da República em exercício, e as palestras que acompanhavam as mostras eram realizadas, muitas das vezes, por pessoas que tinham alguma relação com o cenário político e não necessariamente por especialistas no tema a ser abordado.

Certamente, na capital do país, não seria possível organizar eventos dessa maneira. Lá estava sediada a Escola Nacional de Belas Artes com seus mentores e diretrizes e, assim, todo um contexto institucional de maior exigência para se legitimar enquanto artista. Por isso, não temos relatos de exposições de belas artes que repetissem a mesma interligação com as esferas do poder, nesses primeiros anos do regime republicano. Nem mesmo no circuito privado, nas galerias particulares, teríamos situação semelhante. Tais espaços, como foi apontado por Sônia Gomes Pereira (2003: 19), eram locais importantes para as mostras artísticas que surgiram a partir da década de 1880, momento de escassez de exposições da então AIBA (Academia Imperial de Belas Artes) e, posteriormente, ENBA. Nesse contexto é que se abririam espaços como a própria Galeria Cambiasso, onde aconteceram as primeiras exposições do Photo-Club do Rio de Janeiro, que citamos anteriormente. Nada disso havia em Petrópolis, lugar 
cujo prestígio e privilégio das classes abastadas teriam maior relevância do que o próprio evento de fato.

Inserido em circunstâncias especiais, o movimento de "vilegiatura artística" deixaria marcas na cidade e na produção dos artistas que lá estiveram. Depois de 1907, quando cessaram as exposições organizadas diretamente pelo clube, alguns desses artistas sobem a serra para ali exporem individualmente seus quadros, como fez Salvador Parlagrecco, quando publica na primeira página do jornal Tribuna de Petrópolis (9/3/1907), o seguinte reclame:

"Aos amadores das bellas artes será dada a occasião de apreciar mais uma vez os trabalhos do dictincto artista que ezporá quadros sobre assumptos petropolitanos".

A cidade convertia-se assim em tema para as obras, movimento que será seguido nos anos seguintes por Roberto Mendes, conhecido pintor, muito elogiado pela crítica, que já havia exposto nos salões organizados na década anterior. Estava em Petrópolis para produzir quadros de grande dimensão da natureza local, mais especificamente vistas da serra para o Rio de Janeiro. Tais obras seriam, segundo o artigo, expostas na capital do país e num "salon” na França (Tribuna de Petrópolis, 7/3/1912).

Dentre todos os pintores que escolheriam a partir desse momento a cidade serrana como tema, sem dúvida alguma, o mais representativo foi João Baptista da Costa. De acordo com os dados divulgados sobre as pinturas que estavam em domínio público na revista Ilustração Brasileira (que fez um balanço da obra do artista na ocasião de sua morte em 1926), Petrópolis passou a ser representada em suas telas a partir de 1909. A lista é extensa e a cada ano havia mais obras produzidas cujo título eram os rios, as estradas, os bairros, enfim áreas reconhecidamente da cidade: 1909, Estrada do Bingheu, Westphalia; 1910, Avenida 7 de abril, Avenida Piabanha, Rio 
Morin; 1911, Rhenania, Westphalia, Residência do Barão do Rio Branco, Estrada da Mosela, Avenida Piabanha; 1912, Serra dos Órgãos, Westphalia; 1913, Um cantinho de Petrópolis; 1914, Westphalia; 1915, Alto da Serra, Paysagem do Binghen, Palatinato; 1916, Alto da Serra ao por do sol, Rio Morin; 1917, Paysagem do Retiro; 1918, Itaipava, Estrada do Binghen; 1919, Rhenania, Westphalia, Itaipava (4/1926, anno III, n. 68). Trata-se de uma lista incompleta, até porque muitas pinturas, cujo título era mais genérico como Paysagem e Quaresmas, também eram representações da natureza de Petrópolis. Isso quer dizer que a quantidade de obras é, de fato, muito maior.

Portanto, as exposições cujo objetivo era fomentar a vida cultural na serra, promoveram muito mais do que isso. É possível falar da integração da cidade ao circuito da pintura no período, seja pelo espaço efetivo concedido às mostras, seja por criarem condições, inclusive comerciais, para a exploração da temática da paisagem, ou melhor, da representação dos "jardins cultivados de Petrópolis" como se referia Ronald de Carvalho a Baptista da Costa (Ibid.).

O segundo eixo a ser destacado é a presença do cinema que, embora não tenha sido mobilizado da mesma forma que as exposições de arte, em algumas circunstâncias se vincula à problemática da auto-representação destacada anteriormente. Podemos citar, como um exemplo significativo, a primeira exibição de filmes em Petrópolis, em 1897, no teatro do Cassino Fluminense, o clube de prestígio do período imperial, já em decadência nesse momento.

Talvez, por Petrópolis ser a capital do estado, tenha havido essa primazia, quando o exibidor itinerante Victor de Maio $^{36}$ apresentou quatro sessões cinematográficas na cidade - sendo a segunda vez que filmes eram apresentados no

\footnotetext{
${ }^{36}$ Victor de Maio, depois da apresentação em Petrópolis foi para São Paulo em 1899, onde inaugurou a sala regular de exibição Cinematógrapho Paris, em 1900. Depois disso, esteve em diversas capitais do país (Moura, 1987: 21).
} 
Brasil. A projeção teve considerável propaganda no jornal Gazeta de Petrópolis (1/5/1897), quando foram anunciados alguns títulos que teriam sido realizados na cidade serrana e na capital federal. Dentre os 18 filmes apresentados quatro eram nacionais: Uma artista trabalhando no trapézio do Polytheama; Chegada do trem em Petrópolis; Bailado de crianças no colégio, no Andaraí; Ponto terminal da linha de bondes de Botafogo, vendo-se os passageiros subir e descer.

Muitos pesquisadores já indagaram se ali haviam sido exibidas as primeiras películas filmadas no Brasil. Como o anúncio não se repetiu nas cidades visitadas posteriormente por Vitor de Maio, há quem fale de estratégias comerciais adotadas pelo exibidor; então poderiam ser filmes estrangeiros que tiveram seus títulos alterados (Viany,1959: 28). Outros usam o argumento de que se fosse mentira, um jornal como a Gazeta de Petrópolis, que gozava de prestígio na sociedade local, deveria mencionar nas edições seguintes a suposta fraude, o que de fato não ocorreu (Capellaro; Ferreira, 1996: 58).

Porém, independente de qual seja o argumento adotado, consideramos que na primeira exibição de filmes com películas supostamente nacionais, há elementos representativos do funcionamento daquela sociedade. Afinal, não esbarraríamos aqui no já mencionado desejo de auto-representação? Pode ser então que Victor de Maio tenha feito apenas um apelo comercial ou realizado filmes locais. Porém, qualquer que seja a possibilidade, evidencia-se que, somente em Petrópolis, esse exibidor tentou promover um atrativo diferente, segundo os anúncios no jornal. Nesse momento, a cidade serrana era a capital do estado do Rio de Janeiro e passava por grandes mudanças com aumento expressivo de construções de alto padrão, residências que iriam servir como sede ao corpo diplomático e moradia de alguns privilegiados. Nesse contexto se esboçava o que, alguns anos mais tarde, iria se manifestar com veemência. Trata-se da mencionada 
interferência dos clubes, como os Diários, nos acontecimentos sociais. Mas o quadro já estava montado, de alguma forma, quando Vitor de Maio buscou estabelecer conexão com tais grupos para obter êxito, no anúncio ou exibição dos filmes nacionais. Nada melhor do que ter (ou sugerir) os espaços familiares àqueles que viviam na cidade, na tela de cinema.

A importância do cinema se evidenciaria também na presença de exibidores itinerantes e outros que passaram a montar suas salas nos anos seguintes como José Roberto da Cunha Sales $^{37}$ (1897), Paschoal Segreto ${ }^{38}$ (1902-1905), Empreza Candburg e Gaumont (1905) e Edouard Hervet (1907). Surgiram ainda filiais de importantes cinemas cariocas como O Grande Cinematógrapho Rio Branco (1909) - a sede ficava na rua Visconde do Rio Branco (RJ), sendo de propriedade de Guilherme Auler ${ }^{39}$ - o cinema Odeon (1910), dentre outros.

Merece atenção a produção de filmes locais sobre cenas do cotidiano. Parte dessas películas se enquadra na consagrada expressão de Paulo Emílio Salles Gomes (1986:323-330), "rituais do poder", utilizada para os primeiros anos de produção cinematográfica no Brasil. De fato, estes filmes se detinham no registro da vida social das elites, os próprios grupos financiadores que, por isso, desejavam estar representados na tela. Estavam na categoria, um tanto genérica, denominada no período de "naturais" - tradução do francês "vues d'après nature" - que predominaram na produção nacional até 1907, conforme também aponta Salles Gomes (1996: 24).

\footnotetext{
${ }^{37}$ Cunha Sales foi sócio de Pascoal Segreto no Rio de Janeiro, ambos foram proprietários do Salão de Novidades, inaugurado em 1897, na rua do Ouvidor. Essa foi a primeira sala regular de cinema do país. A sociedade se desfez nesse mesmo ano, quando Cunha Sales faz suas apresentações em Petrópolis e depois em São Paulo (Ibid.: 19).

${ }^{38}$ Paschoal Segreto arrendou espaços em diversas cidades, onde manteve seu Salão de Novidades como São Paulo, Santos, Campos e Niterói. Foi dono de diversos empreendimentos populares como Coliseu Boliche, Parque Fluminense, etc. Seu irrnão, Afonso Segreto, era também cinegrafista, tendo realizado algumas das primeiras filmagens nacionais (Souza, 1998: 51).

${ }^{39}$ Guilherme Auler inaugurou sua sala no Rio de Janeiro em 1907, tendo sido sócio do Cinematógrapho Pathé, de propriedade Arnaldo G. de Souza e Marc Ferrez (2004: 268).
} 
No registro de eventos, Paschoal Segreto foi o primeiro a produzir filmes sobre a cidade, já em 1898: A chegada do Dr. Campos Sales a Petrópolis e Baldeação da barca de Petrópolis. Depois, apenas em 1909 foi exibido, Uma excursão a Petrópolis. Tratase aqui de uma produção do Cinematógrapho Rio Branco, que organizou a saída do Rio de Janeiro (no valor pago, estava incluído almoço com a presença da cantora Claudine Montenegro). Em 1911 encontramos A inauguração da estátua de Pedro $I^{40}$, que foi levado para o pavilhão do Brasil na exposição de Turim, ocorrida nesse mesmo ano; e $O$ natal dos pobrezinhos em Petrópolis ${ }^{41}$, festa de caridade promovida anualmente pelo Club dos Diários. No ano seguinte começam a ser filmadas as festas do próprio Carnaval no Club dos Diários ${ }^{42}$. Houve ainda Os melhoramentos de Petrópolis ${ }^{43}$ de 1914.

A vida familiar de elite também obteve atenção dessas produções, que tiveram apenas exibição local. Em 1908 foi produzido Sahida da matinée no Theatro casino de Petrópolis no último domingo; a graciosa menina Olga jogando no jardim do Palácio do Rio Negro com as suas amiguinhas ${ }^{44}$. No ano seguinte há outro filme sobre um evento doméstico, A sensacional vista As bodas de Ouro do exm. Sr. Visconde de Ouro Preto, na egreja de Santo Antonio, no Alto da Serra ${ }^{45}$. Nesse caso, trata-se de dois filmes de família, cujo interesse certamente era bastante restrito. No entanto, houve propaganda nos jornais da cidade que destacava, entre as demais películas, as produções locais. Em 1913 houve um evento socialmente relevante, que ocupou as páginas dos jornais, quando foram realizados $O$ casamento de sua Excia. O Marechal Hermes

\footnotetext{
${ }^{40}$ Tribuna de Petrópolis, 12/2/1911.

${ }^{41}$ Id., 30/12/1911.

${ }^{42}$ Id., $16 / 4 / 1912$.

${ }^{43}$ Id., 29/3/1912.

${ }^{44}$ Id., 8/2/1908.

${ }^{45}$ Id., 20/1/1909.
} 
Rodrigues da Fonseca ${ }^{46}$, encomenda do Cinema Rio Branco, filmado por Paulino Botelho; havia, ainda, $O$ casamento do Marechal Hermes ${ }^{47}$. Ambos os filmes, que registravam o casamento do Presidente da República com Nair de Teffé, passaram em diferentes cinemas durante vários dias, tendo destaque nas propagandas. Mas aqui, a produção teve maior repercussão com exibições em outras cidades, pois tratava-se de registros em torno da vida presidencial.

É preciso ressaltar que, nesse momento, temos outros casos em que famílias contratavam cinegrafistas para fazer filmes, registrando acontecimentos de cunho doméstico, como ocorreu em São Paulo ${ }^{48}$. A diferença de Petrópolis se deve, apenas, à articulação daqueles que seriam filmados, com as esferas oficiais do poder. Havia um quadro específico de famílias que ficavam num contínuo trânsito (físico e imaginário) entre a cidade serrana e a capital do país. Muitos ainda mantinham antigos títulos nobiliárquicos, herdeiros do período imperial, situação característica da classe social dominante que lá habitava e, de alguma forma, demarcada também na produção cinematográfica local.

No caso do cinema, porém, havia dependência externa a esses grupos locais (produtores, cinegrafistas), diferentemente das exposições de arte. Por isso, aqueles que estavam associados aos Diários manifestariam suas críticas ao próprio Paschoal Segreto, que se instala na cidade em 1902, aluga o Palácio de Cristal, e lá permanece com seu “Salão de Novidades", o "Centro de diversões populares" até 1906. Segreto mantinha na serra algo similar à sua sala de cinema conhecida do Rio de Janeiro. Os filmes eram ali

\footnotetext{
${ }^{46}$ Tribuna de Petrópolis, 10/12/1913.

${ }^{47}$ Ibid.

${ }^{48}$ A respeito da produção em São Paulo, Eduardo Morettin (2005: 142-148) faz importantes observações em sua análise do filme Caça a Raposa, de 1913 (realizado por Antônio Campos), sobre a família Guedes Penteado. Esse é um caso interessante porque a própria caça, que está no título do filme, não existiu de fato, tendo sido encenada. Trata-se também aqui de uma elite que mantinha tênues limites entre o público e o privado, ansiosa por demarcar sua condição social, status e caráter refinado (em face de mudanças na capital paulista como, por exemplo, a "chegada e ascensão econômica dos imigrantes"). O circuito de exposição era complementado simbolicamente pela circulação ampliada de imagens fotográficas em revistas ilustradas (sobre este evento, a matéria foi publicada na revista Careta).
} 
apresentados entre outras atrações, geralmente muito variadas, com malabaristas, números de mágica e, aos domingos e feriados, havia também "carroussel, montanha russa e fio aéreo" (Tribuna de Petrópolis, 7/5/1904).

Em 1906, o contrato foi rompido, momento em que surgem críticas indicativas do modelo de divertimento que, segundo as elites petropolitanas, não deveriam integrar aquele núcleo social. Diziam que Segreto havia dado prejuízo à Prefeitura e destruído o Palácio. Para desmentir os boatos o próprio Prefeito publicou um balanço no jornal, demonstrando os lucros obtidos com o "Salão de Novidades" (Tribuna de Petrópolis, 23/10/1906). Mas pelo menos no que se refere ao cinema, a presença do divertimento de cunho popular seria coisa do passado. A partir de então o Palácio de Cristal foi arrendado até a década seguinte pelo Club dos Diários ${ }^{49}$ para ali sediar as principais festividades do "Verão em Petrópolis".

\section{Alberto de Sampaio e a fotografia amadora}

Alberto de Sampaio teve participação intensa na vida social da cidade de Petrópolis, desde o século XIX, sendo um membro ativo de diversos clubes. Um dos primeiros em que ele se manteve associado, tendo sido fundador, foi o Cycle Club do Brasil, em 1898, voltado exclusivamente para a prática do ciclismo. Nesse momento, era muito jovem, já havia iniciado a atividade fotográfica e, possivelmente, dispunha de tempo para se dedicar a essa associação.

No ano seguinte o clube publica um Almanak Cyclistico contendo desde informação técnicas sobre bicicletas, horários de trens e até um mapa indicando o caminho que poderia ser percorrido entre o Rio de Janeiro e Juiz de Fora. Ali, Sampaio também escreveu (usando o mesmo pseudônimo, Alpha, com que assinava suas poesias)

\footnotetext{
${ }^{49}$ O Club dos Diários fecha a sede social que ficava em Petrópolis em 1917 (mantém apenas a do Rio de Janeiro), e encerra suas atividades em 1921.
} 
contando como surgiu a idéia de fundar o clube, sua iniciativa para agregar as pessoas, e o fato de ter escrito todos os estatutos dessa associação. Fica também, nesse caso, ressaltada a idéia da mobilização empreendida pela iniciativa particular para melhorias das estradas, que teve como resultado a intervenção direta de trabalhadores em longos trechos, até mesmo para a construção de abrigos para os ciclistas.

A lista de sócios é indicativa de que integravam ao clube "os granfinos" 50 da serra, como João Teixeira Soares, Joaquim Murtinho, Eduardo Guinle, Alberto Nepomuceno, Barão de Santa Margarida, Conde de Afonso Celso, Visconde do Rio Preto e muitos estrangeiros, que certamente, eram membros das legações que estavam em Petrópolis. Mas a atividade clubística do ciclismo não teve longa duração, embora existam diversos relatos de festas com competições organizadas pela associação. Apesar de ser um clube masculino, havia menções a participação de mulheres, muitas delas tendo sido premiadas.

Em 1906 Alberto de Sampaio integrava o "comitê de festas", incumbido de organizar o "Verão em Petrópolis" do ano seguinte, todos sócios do Club dos Diários e que, portanto, se responsabilizavam pelo evento. O grupo era composto por 50 membros do clube que haviam doado para o futuro evento, cada um, 100\$ (Tribuna de Petrópolis, 13/12/1906). Ora, este valor era consideravelmente elevado, pois a assinatura anual do jornal Tribuna de Petrópolis custava apenas 14\$. A contribuição, à parte das mensalidades cobradas por qualquer integrante do clube, nos indica o grau de comprometimento desses grupos com a cidade. Sampaio fez parte também de outras associações, como o Club de Tiro Petropolitano. Era um membro representativo, pois participou num concurso realizado em 1909 no Rio de Janeiro, quando foi organizada

\footnotetext{
${ }^{50}$ Em texto publicado no jornal Tribuna de Petrópolis e reunido em livro de crônicas em 1944, José Kopke Fróes faz referência ao clube dos "granfinos", Cycle Club do Brasil, presidido por Alberto de Sampaio, e ao Velo Sport dirigido por Miguel Santos (apud Pereira: 2004: 52).
} 
uma festa para algumas sociedades de tiro tendo, inclusive, a presença do Marechal Hermes da Fonseca.

Em relação à fotografia, no circuito familiar de Alberto de Sampaio haveria outros fotógrafos amadores que merecem ser destacados. O mais antigo era Machado Coelho ${ }^{51}(1834-?)$, possivelmente um tio-avô, e que na década de 1860 fazia fotografias que mereceram notas de Luiz Agassiz ${ }^{52}$ em seu livro Viagem ao Brasil; 1865-1866 (Pereira, 2004: 42). No mesmo ramo familiar, Alfredo Ferreira Laje foi o mais expressivo em sua atividade como amador, pois foi, como vimos, o fundador do PhotoClub do Rio de Janeiro. Apesar de terem grau de parentesco próximos, não temos relatos de ter havido relação direta entre esses fotógrafos, diferentemente de Otávio Mendes de Oliveira Castro (casado com a irmã de Cecília Sampaio), que foi companhia constante para a atividade fotográfica, seja em cenas da família, seja em passeios com o objetivo de fazer registros da paisagem.

Vale lembrar que Petrópolis teve enorme destaque na expansão da fotografia naquele período devido, principalmente, à presença da família imperial. Isso porque D. Pedro II foi grande incentivador da atividade em nosso país, tendo sido também um praticante e, conforme ressaltou Pedro Vasquez (1985), o primeiro fotógrafo amador do Brasil. A iniciativa de oferecer prêmio de distinção de "Photographo da Casa Imperial" a diversos profissionais, além da extensa coleção de fotografias que englobavam retratos e registros da paisagem brasileira, são alguns dos elementos que demonstram o interesse

\footnotetext{
${ }^{51}$ Manuel Machado Coelho era irmão do avô materno de Alberto de Sampaio (José Machado Coelho de Castro). Era também cunhado de Mariano Procópio Ferreira Laje.

${ }^{52}$ Louis Agassiz chefiou a expedição científica Thayer (1865-1866). Começou no Rio de Janeiro sendo formada por diversos desenhistas e fotógrafos, dentre eles George Leuzinger (1813-1892) e Augusto Sthal. Em Juiz de Fora, Agassiz ficou hospedado na fazenda de Mariano Procópio Ferreira Laje em 1865. No livro Viagem ao Brasil: 1865-1866 (1975:78) há menção a este "Sr. Machado" como sendo "excelente fotógrafo" (Vasquez, 1998:21)
} 
e envolvimento do imperador, um verdadeiro entusiasta que presenciou a invenção da nova técnica de produção de imagens.

Em tal contexto, Petrópolis seria visitada pelos importantes profissionais do século XIX que deixariam seus registros da cidade. Alguns deles iriam montar ali seus estúdios como Revert Henrique Klumb, José Ferreira Guimarães, Karl Papf, Philipe Hees, dentre muitos outros. A respeito do desenvolvimento da fotografia, como prática amadora, há anúncios de jornais que indicam a venda de equipamentos e ensino da atividade para os não profissionais e, ainda, uma única referência sobre a formação de um suposto grupo. No jornal Gazeta de Petrópolis de 20 de abril de 1895 foi publicado uma pequena notícia: "Consta-nos que alguns cavaleiros desta cidade, tratão de constituir-se em sociedade para promover o progresso e vulgarização da photographia em suas aplicações científicas, industriaes e recreativas" (apud Pereira, 2004:75). Apesar de não haver outra menção a essa notícia nas edições seguintes (devido, certamente, à não constituição da sociedade) temos aqui um indício de que haveria na cidade diversos praticantes da fotografia de maneira também "recreativa" ou, por assim dizer, amadora.

Embora haja escassez de informações, temos dois praticantes que merecem ser mencionados. O primeiro é a própria princesa Isabel, que teve aulas de fotografia em Petrópolis, como nos informa Pedro Vasquez (2000: 59), quando Klumb manteve na cidade serrana seu estúdio, em 1865. Havia ainda Henrique Kopke Júnior (1848-1917) advogado que atuou em diversos cargos políticos, tendo sido prefeito da cidade. Segundo relato de Gabriel Fróes, Kopke Júnior esteve na Inglaterra em 1872 e lá aprendeu as técnicas fotográficas, num país que tinha enorme tradição da atividade amadora exercida no âmbito dos clubes (Tribuna de Petrópolis, 26/11/1957). Ao que 
tudo indica, ele foi um amador reconhecido, segundo o relato, até mesmo pelos profissionais sediados em Petrópolis.

Estando nesse contexto, em parte, propício para a fotografia, Sampaio estabelece certos vínculos com o profissional Jorge Henrique Papf, que nasceu na Alemanha e era filho do fotógrafo e pintor Karl Ernest Papf ${ }^{53}$. Jorge Henrique já anunciava nos jornais em 1888, mas apenas em 1895 iria assumir definitivamente os trabalhos do estúdio, originalmente pertencente a seu pai. Nesse mesmo momento, a partir da última década do século XIX, Sampaio e sua família foram registrados por Papf, aliás, o único que produziu imagens daquele grupo, tanto na residência como no estúdio. A proximidade pode ser atestada, também, por haver uma nota de compras de material da empresa “Officina de Photographia” do próprio Papf, em 1899, na qual Sampaio adquire alguns negativos, além de "retratos em platinotypia". E, ainda, por um raro retrato desse fotógrafo profissional em seu ambiente de trabalho feito em 1906, de autoria de Alberto de Sampaio (Pereira, 2004: 62-72).

A relação de proximidade entre amadores e profissionais era, de fato, uma realidade, num momento em que não havia instituições voltadas para o ensino da fotografia, como atestam os jornais de Petrópolis. Já em 1883, um estúdio fotográfico oferecia entre seus serviços aulas para os amadores. Depois encontraríamos nos jornais outros anúncios em 1906, 1910 e 1914 se referindo as aulas que podiam ser ministradas mediante compra de material no estabelecimento ${ }^{54}$.

\footnotetext{
${ }^{53}$ Essa foi mais uma das tantas famílias estrangeiras que vieram para o Brasil a fim de atuar no campo fotográfico, no século XIX. Primeiramente Karl Ernest Papf (1863-1910) foi empregado de Albert Henschel \& Cia., mais tarde, Photographia Alemã. Somente em 1886 ele se instala em Petrópolis fundando um dos mais importantes ateliers fotográficos da cidade (Levy, 1980; Kossoy, 2002).

${ }^{54}$ Em 25 de agosto de 1883, João Nogueira de Souza publica anúncio no jornal $O$ mercantil, se dirigindo "aos photographos e amadores". Ele vendia equipamentos fotográficos e chapas secas (negativos em vidro) que eram uma novidade, pois substituíram o trabalhoso processo do colódio úmido. Além disso, havia "explicação" de como usar o material. No jornal Tribuna de Petrópolis em 1906, há vários anúncios de um estabelecimento que oferecia aula aos fotógrafos amadores das "10 ás 3 horas da tarde", onde também podia-se adquirir equipamentos e encomendar trabalhos fotográficos. Já em 1910 "Photographia Cinematographica - Mauri, Filho \& C. publicou no jornal O Cruzeiro anúncio direcionado aos amadores.
} 
Tal relação de profissionais com o ensino da fotografia já foi apontada por Ana Maria Mauad (2001: 193) como sendo necessária para a própria sobrevivência dos estabelecimentos, pois havia concorrência acirrada entre os estúdios. Conforme também Boris Kossoy (2002: 40) ressaltou, desde os anúncios publicados pelos primeiros fotógrafos estrangeiros que aportaram no Rio de Janeiro, por volta de 1850, era comum que aulas particulares fossem oferecidas aos interessados em aprender procedimentos técnicos. Esse tipo de associação fica bastante exemplificado por Suzana Barreto Ribeiro (2006: 93) que analisou a produção do fotógrafo amador Austero Penteado. Nesse acervo, há uma carta, aqui já mencionada, do profissional sediado no Rio de Janeiro, A. Leterre, endereçada ao amador, contendo várias indicações sobre uso de químicas em laboratório. Embora não saibamos se tal forma de correspondência constituía em padrão, trata-se, mesmo assim, de um caso muito representativo, pois, apesar de estar em Campinas, cidade muito distante da capital do país, Penteado mantinha vínculos com um profissional.

Apesar de serem exemplos esparsos e não poderem constituir uma amostragem, os poucos amadores que deixaram informações sobre suas atividades e trajetória revelam também associações estreitas, muito próximas entre a pintura e a fotografia. Foi o que aconteceu com Austero Penteado que, ainda segundo Ribeiro (2006: 86), teve em certas ocasiões o pintor Campos Aires como companheiro de passeios, quando já não mais se dedicava à atividade fotográfica. Sabe-se que Penteado foi grande admirador e colecionador de pinturas. Outro amador que obteve bastante destaque, por ter alcançado premiações internacionais importantes, foi Francisco do Nascimento Ramos, que usava

Eles vendiam equipamentos, revelavam fotografias e davam aulas sobre os procedimentos técnicos. Em 1914 já aparece nota sobre outro estabelecimento que ensinava fotografia pelo processo Luimère. Trata-se do autocrome, método que gerava transparências coloridas em chapas de vidro (apud Pereira, 2004: 7577). Há ainda outra nota - "Quarta combinação todos os photographos" - sobre vendas de câmeras, equipamentos para revelar ressaltando que a "foto não é mais segredo de ninguém (Tribuna de Petrópolis, 25/5/1910). 
o pseudônimo de Lunara. Como ressaltou Eneida Serrano (1980), saía para fotografar em Porto Alegre com os artistas Pedro e Miguel Weintgartner e, por isso, é possível notar diversas semelhanças entre as pinturas e as imagens do amador. Com Alberto de Sampaio encontramos as mesmas circunstâncias. Seus primeiros estudos em desenho começaram em 1886, data do caderno que contém diversos estudos de paisagem e figura humana. $\mathrm{O}$ interesse se estendeu à pintura e Sampaio se dedicou à aquarela tendo sido aluno de Brenno Treidler, pintor alemão, muito respeitado em sua atividade, que chegou ao Brasil em 1885. Participou de várias exposições de Escola Nacional de Belas Artes e foi professor de pintura de diversos outros artistas do período.

É preciso ressaltar que essas informações são indícios importantes também da força do discurso estético que dominava toda literatura destinada ao público amador de elite, presentes nas primeiras associações no Brasil e nas publicações nacionais e estrangeiras que tinha circulação em nosso país.

\section{Petrópolis: cidade da pose}

Petrópolis teve espantoso crescimento na época do encilhamento: quando, como diz Nicolau Sevcenko (2003:37), especuladores levaram a falência antigos grupos que gozavam, muitas vezes, apenas pelo status, de alto prestígio social. A instância de veraneio não só se beneficiava dos novos ares republicanos no cenário de ampla instabilidade econômica. Ali essa elite, por assim dizer "antiga", responde aos novos tempos interferindo diretamente na vida social da cidade. Transforma o espaço público num palco de diversas intermediações entre a vida pública e privada, onde as tensões, ambigüidades e contradições daquela sociedade se expressaram com veemência.

Isso porque a cidade se transformou num espaço de articulação simbólica dessa classe, que ali estabeleceu estratégias de legitimação cultural de forma consciente não 
apenas para promover diversão e lazer para aqueles que lá estavam. Suas preocupações também não se restringiriam ao desenvolvimento do espaço urbano, já que ali agiriam forças para manter determinada importância e status de um grupo que se via ameaçado - o desejo de se integrar à capital federal revela uma parte desse processo. Petrópolis era, antes de tudo, como uma vitrine em que todos aqueles grupos de perfil burguês encontrariam certa visibilidade, um espaço associativo em que os "clubes" seriam os principais mediadores e reguladores da vida social.

Tudo isso ocorria num contexto específico. O Rio de Janeiro, nosso principal centro político, econômico e social daquele momento, era o símbolo máximo da modernização com as reformas empreendidas por Pereira Passos. Mas o fato é que os grupos de elite da capital do país e, ao mesmo tempo, da serra assistiam a perda da importância das fazendas fluminenses como principal centro produtor de café. Havia as profissões liberais, ocupações dos membros dos novos Clubs, como se refere Jeffrey Needell (1993: 95), mas o declínio econômico era inegável. Circunstância reconhecida pela própria imprensa que se dedicará, em parte, na construção da imagem da cidade como lugar de freqüência de privilegiados, de belezas naturais e arquitetura suntuosa, mas que, por outro lado, evidenciará também as ambigüidades daquela cidade de veraneio.

A revista Kosmos, que publicava, em muitas de suas páginas reportagens sobre Petrópolis - mantendo sempre certa reverência ao estilo de vida daquela população cuja presença do corpo diplomático teria papel crucial - também conferia espaço para algumas críticas. Em 1906, numa longa matéria sobre Petrópolis, quando foram publicadas diversas fotografias que exaltavam ora a natureza domesticada, ora os aspectos urbanos, há outros indícios da vida social local: 
"Cidade de luxo, tal é a fama de Petrópolis, fama que talvez a prejudica mais do que a serve. Cidade de luxo, sim, mas dentro dos limites em que o pode ser uma cidade no Brasil, terra opulentíssima de gente pobre. [...] E grande numero de pessoas do high-life (seria pretensioso dizer aristocracia) das terras mais vizinhas de Petrópolis, possuem nessa cidade habitações de verão, ou ahi moram permanentemente. Faz isto que no seio de sua pequena população avulta um grupo de gente rica, ou que tal parece, e que vive com relativo luxo. E como ao cabo a vida em Petrópolis é barata (havendo até quem ahi more por economia) pois a cidade não offerece tentações para grandes dispêndios, nem tem proporções para o grande luxo, mesmo os pouco abastados, e são a grande maioria de sua população adventícia ou fixa, podem durante quatro ou seis mezes, campar de ricos (anno III, março 1906, n. 3).

Sob essa ótica, em Petrópolis havia uma tensão revelada pelo desejo de “parecer” tal como elite, um mecanismo social eficaz num espaço disputa simbólica. Por isso, ele continua com a mesma crítica nas linhas seguintes, e como eram poucos os que tinham carruagens particulares ou mesmo automóveis:

O mais é muito falso luxo, e o snobismo e rataquoérismo, próprios de aglomerações semelhantes, constituindo tudo um espetáculo que não é menos interessante e divertido para o observador que se não deixa empulhar, e que faz parte das curiosidades de Petrópolis (Ibid.).

Num período de instabilidades e mudanças de ordem econômica, o mundo das aparências externas, de certa representação, seria uma constante na capital do país como foi bem ressaltado por Sevcenko (2003). Em Petrópolis, no entanto, havia uma situação específica em virtude do passado histórico da cidade, da pequena dimensão da urbe, e, portanto, da forma como concentrava os grupos que viviam relações de vizinhança e proximidade.

Júlio Ambrózio (2008: 241-242) faz importantes observações a esse respeito. Para o autor, Petrópolis foi planejada como uma "cidade doméstica": tinha condições políticas especiais (nasce da compra de fazendas pelo Imperador), de relevo (espaços estreitos, situados nos vales, para sua efetiva ocupação) e ausência de terras públicas (daí o código de posturas ter sido realizado apenas na República). Ambrózio identifica 
já no projeto elaborado pelo major Koeler $^{55}$ certa segregação sócio-espacial, que autenticaria a centralidade dos espaços privativos, em casas dos bairros centrais ocupados pela elite imperial (Vila Thereza e Vila Imperial). O Palácio Imperial constituía-se no marco daquele núcleo e não igrejas e espaços públicos, como na maioria das cidades brasileiras. As ruas serviam muito mais como ligação entre essas moradias e havia ausência de praças: Koeler projetou 15, mas apenas cinco foram construídas na região próxima ao Palácio; já nas áreas denominadas de quarteirões ${ }^{56}$, mais afastadas do núcleo onde habitava a elite imperial, todas ficaram no projeto.

Tal fato de a cidade ter sido idealizada como uma extensão da residência do imperador nos indica já haver pré-condições para a preponderância exacerbada da vida privada sobre a pública, observada na virada do século XIX. Isso porque Petrópolis vivia longe das contradições da capital do país local cuja arquitetura, hábitos e cor da maioria da população local não podia esconder as longas décadas de origem colonial. Por isso, seria lugar privilegiado para a construção de novos hábitos calcados em antigos, como resposta à situação vista em desprestígio.

Os estudos sobre classe de Pierre Bourdieur (2001: 16) nos auxiliam a compreender os mecanismos sociais que agiam em Petrópolis nessa virada do século XIX. Ressaltando que em diferentes sociedades existem propriedades de posição que podem ser equiparadas seguindo a análise estrutural de uma determinada trajetória social de grupos e indivíduos, o autor ressalta o relevo das relações simbólicas (em que universo material e de ordem econômica é subjugado) que os grupos estabelecem entre si. Essas práticas comuns de diferenciação se estabelecem no consumo ostentatório (e

\footnotetext{
${ }^{55}$ Francisco de Vasconcellos ressalta também que, o próprio Decreto Imperial de 1843, de fundação de Petrópolis (só foi elevada a categoria cidade em 1857), juridicamente, era um documento com muito mais características privadas.

${ }^{56}$ Ambrózio (2008: 237) observa que o vocábulo quarteirão e bairro seriam similares. Porém, ressalta diferença na definição, como encontrado no dicionário Aurélio Buarque de Hollanda. Quarteirão estaria "separado da centralidade", ao contrário da noção de bairro de onde provém noções como "bairrismo", como aquele que defende interesses e tem preocupações com o lugar.
} 
aqui ele ressalta Veblen) que transforma as "diferenças" em "distinções", "valores, privilegiando a maneira, a forma da ação ou do objeto, em detrimento de sua função".

Elementos dessas formas de mediação e articulação podem ser observados em diversas instâncias daquela sociedade como nas festas organizadas por esses grupos. Em 1902, por exemplo, o Club dos Diários organizou um grande piquenique para seus membros na Cremerie Buisson, espaço com lagos e arborização, onde havia uma fábrica de queijos de origem francesa. Parecia ser um dos tantos piqueniques organizados na cidade, porém, esse seria diferente. Isso porque foi organizada uma festa suntuosa e mesmo curiosa. Muitos membros do clube partiram do centro da cidade em carruagens decoradas, havendo um grande desfile acompanhado por uma banda para celebrar a ocasião. O encontro foi grandioso contanto com a participação de cerca 195 pessoas que eram membros do clube, diplomatas e políticos. Mas havia ainda todos os empregados que preparam a festa como cocheiros, cozinheiros e ajudantes. A quantidade de pessoas envolvidas no evento era, portanto, muito maior. $\mathrm{O}$ almoço não poderia ser diferente: havia diversas mesas ornamentadas e a comida foi servida por um chef francês, cujo cardápio figurava nas páginas dos jornais locais e também na revista que surgiu a partir desse ano "O verão em Petrópolis" "57 . A suntuosidade do evento beirava o exagero que, por certo, não era fortuito. É preciso ressaltar que, nesse caso, a ostentação tinha função social.

A cidade serrana se constituía um universo à parte, espaço privilegiado para a demonstração expressiva de diferenças de toda ordem, que podiam ser mobilizadas pelos segmentos mais privilegiados. Essas marcas de distinção se manifestavam em quase todos os clubes sociais que existiam ali. Alberto de Sampaio, por exemplo, participava do Club de Tiro Petropolitano, o qual não ficava restrito aos treinos e

\footnotetext{
${ }^{57}$ José Kopke Fróes publica um relato detalhado em artigo "Curiosidades Petropolitanas. Pic-nic em 1902" no Jornal de Petrópolis em 13/12/1964.
} 
caçadas empreendidas por seus membros. Em 1909 eles organizaram uma demonstração pública: saíram em marcha devidamente uniformizados pelas ruas do centro acompanhados por "dois corneteiros, e dois tambores do exército que subiram especialmente para esse fim” (Tribuna de Petrópolis, 9/5/1909). Ora, esse era apenas mais um dia de treino que foi transformado numa exibição, tendo como palco a ruas centrais de Petrópolis. Se o clube recorria à demonstração teatral, as festas de caridade organizadas pelos próprios membros dos Diários eram outro componente da estrutura organizada para marcar posições, diferenciações entre as classes. A caridade demonstrava assim a distância de uma determinada classe das demais, constituindo um recurso simbólico, altamente eficaz. De fato, como os eventos tinham importância, foram tema para alguns filmes que passaram exclusivamente na cidade, conforme citamos anteriormente.

O problema da representação social em Petrópolis se manifesta, também, de maneira exacerbada, na produção textual do período. Afrânio Peixoto (1962: 63), um legítimo integrante do "alto mundo" petropolitano, deixou no romance, já citado, $A$ esfinge (1911), críticas severas ao que ocorria nos espaços de articulação dessa elite. Há certo desconforto do personagem principal, Paulo, o artista recém chegado da Europa, que não se adapta àquele mundo composto por uma rotina de jantares em casas de famílias importantes e freqüência aos clubes sociais. Universo em que, segundo sua descrição, era palco privilegiado para conveniências de toda a ordem, lugar da pose e das aparências, conforme descrito pelo autor:

"A casa da Avenida Koeler, aos sábados, era pequena para comportar as senhoras e cavalheiros que desde as quatro e meia começavam a chegar. Pelo salão, corredores, varandas, gabinetes de passagem, e até o jardim, formavam-se grupos, aos acaso dos encontros, ou à vontade das preferências, numa preocupação de mostrar alegria, fazer graça e contar novidades, que se refletia no ar constrangido, estudado, artificial, ordinário dessas reuniões, ao contrário 
do prazer simples da companhia amável que se procurasse, para a simpatia de uma doce prática de idéias e sentimentos".

Depois, Afrânio Peixoto (1962: 52) descreve os comportamentos dos “tipos” que participavam das reuniões: um conjunto de gestos, roupas e conversas altamente previsíveis e muito "artificiais". Nos jardins do antigo Palácio Imperial, que havia se convertido em sede para prática do Lawn-tennis - um verdadeiro "campo de jogo" freqüentado por diplomatas e a alta sociedade - ele conversa com "Gustavo Lessa, estudante da Politécnica e escritor de crônicas elegantes para os jornais do Rio". Naquele lugar, Paulo observa uma jovem lendo um livro e Lessa ironicamente diz que “Talvez" seja "o Ornamento das núpcias espirituais de Ruysbroeck”. Mas Paulo se indaga: "E isso é leitura para campo de tênis?". Com naturalidade e ironia Lessa assim responde: "Não. Aqui ela vem posar de contraste a estas damas fúteis e mostrar aos homens a capa dos livros que não lê". Trata-se de uma referência a um místico medieval, altamente erudita. Contrasta, portanto, de maneira exagerada com o universo mundano do clube de tênis. Exagero, por certo, encontrado no próprio ato de encenação da leitura e também na cidade de Petrópolis. É, por isso, sugestiva, na menção ao título da obra, a palavra "Ornamento" que desempenha inclusive função narrativa, pois simbolizava de maneira genérica aquela própria sociedade.

Num cenário de forte instabilidade social e mudanças significativas dos primeiros anos do século XX, os antigos atores que dominavam o cenário econômico e político da capital do país precisavam manter seus antigos privilégios. É dentro desse contexto que Petrópolis se tornará num lugar não apenas de veraneio, mas, sobretudo, num ponto focal de atenção, onde as garantias de manutenção da visibilidade pública serão o conteúdo principal da vida social. 
Mas por que em Petrópolis não foram fundados de fato clubes de fotografia? Sabemos que havia diversos praticantes e, inclusive, que todos os fundadores do PhotoClub do Rio de Janeiro veraneavam na cidade serrana. Até mesmo no âmbito das sedes diplomáticas havia amadores como Edgar Haniel, Secretário da Legação Alemã,que participa da Exposição do Photo-Club em 1904. Nenhum deles, porém, exibe na serra suas fotografias, nem mesmo na ocasião das exposições de arte organizadas pelos clubes de elite.

Essa ausência nos leva a pensar numa hipótese, afinal, o Photo-Club tinha como objetivo promover o encontro de "certos" homens de elite, somente aqueles que partilhavam de um interesse comum que englobava a fotografia e as discussões estéticas. Era por isso um espaço de celebração e mediação, indiretamente, de práticas que vinham de fora. A própria trajetória de seus membros, que estiveram na Europa, revela esse caráter de mediação mais forte com a cultura importada. Mas não apenas porque eles se punham a ler revistas e manuais estrangeiros, mas porque tinham aqui um projeto claro e definido: introduzir no Brasil o modelo de fotografia já amplamente difundido entre os amadores europeus. Estamos falando de uma atividade que trazia já em suas origens objetivos quase pedagógicos, de formação de olhar, e daí as palavras de ordem como interpretar.

Petrópolis, ao contrário, era o lugar propício para outro tipo de associação que deveria manter vínculos consigo mesma, seja para o puro divertimento ou o estabelecimento de relações com as esferas do poder. Muito apropriado para o clube de ciclismo cuja prática do espaço num tipo de turismo e determinado uso do corpo tinha como objetivos explícitos obter saúde e bem estar. Ou ainda o Club dos Diários local em que as elites podiam desfrutar de certo prestígio, promover encontros e estabelecer um tipo de solidariedade que facilitava, conforme se refere Needell (1993: 105), "o 
convívio entre os poderosos e suas famílias”. Nesse contexto, porém, de forte desejo de auto-representação e diálogo com diversos aspectos da cultura fotográfica do início do século, em que os amadores ocupavam papel de destaque, Alberto de Sampaio irá produzir suas imagens. As tensões e ambigüidades daquela época, conforme iremos analisar a seguir, deixaram marcas em sua atividade amadora. 


\section{CAPÍTUlO 4. A PRODUÇÃO AMADORA DE ALBERTO DE SAMPAIO}

\section{A produção}

Alberto de Sampaio começa sua atividade fotográfica em 1888 quando tinha apenas 18 anos. Conhecemos dessa data uma única imagem em que o próprio fotógrafo amador aparece ao lado de amigos num chamado "pic-nic" na Gávea (Fig. 1). Nos anos seguintes, pelo menos até 1905 sua produção é escassa e apresenta certa unidade de temas e formas de representação. Esse é o momento de formação, em que ele experimenta, produz muitas fotografias que foram mal expostas e com composição mais simples. Algumas delas vão parar num álbum com título de "destruídas". Enfim, trata-se de um período de aprendizado. As referências pictóricas oriundas do campo fotográfico profissional, bem como sua formação em desenho e pintura, como veremos posteriormente, serão nesse momento já extensamente mobilizadas. Nota-se, contudo, em certos aspectos, uma clara diferenciação da produção profissional do período em algumas raras tomadas casuais em ruas (cópias que, em sua maioria, estão danificadas).

As diferenças mais marcantes seriam pontuadas somente no século $\mathrm{XX}$, no momento em que sua produção se eleva, entre 1905-1914. É nesse mesmo momento, como vimos, que serão introduzidos alguns elementos importantes para a cultura amadora em nosso país, tanto relativo ao universo dos fotógrafos "artistas" como daqueles que usavam a câmera Kodak. 
Seguindo os dados encontrados no conjunto de fotografias que estão referidas no caderno de anotações e nas inscrições com data, nos negativos de vidro, sabemos que apenas 69 imagens foram produzidas por Sampaio nesses anos finais do século XIX. Depois disso há um período de transição em que a produção anual se torna mais escassa ainda, entre 1902-03, quando foram realizadas apenas 11 fotografias. Nos anos seguintes entre 1904-1914 a situação se altera drasticamente de forma quantitativa, pois aí estão concentrados cerca de $90 \%$ da produção total registrada. Isso significa nada menos do que 796 imagens. Mas havia ainda as fotografias, referente a esse segundo momento, 135 registros, que não trazem nenhum dado descritivo sobre datas.

Se em termos quantitativos a mudança fora expressiva, qualitativamente a situação é mais complexa. Há, por um lado, determinadas continuidades no que se refere aos diálogos com o universo profissional e, por outro, alterações significativas, para Sampaio, na percepção do que era a fotografia, quais seus objetivos e formas de apreensão. A natureza como lugar próximo e de acolhimento, a família e o espaço doméstico como unidade autônoma e não como patrimônio, e a cidade num misto de natureza e artefato são alguns dos elementos reintroduzidos pelo fotógrafo nos anos de intensa produção fotográfica.

Consideramos assim dois momentos importantes na produção de Sampaio, embora seja preciso apontar determinadas variações, como demonstraremos posteriormente na apresentação das séries fotográficas. É preciso destacar, no entanto, que três regiões foram registradas ao longo de todo esse período. Trata-se de Petrópolis, Rio de Janeiro e as fazendas de seus familiares. São lugares que, de alguma forma, pertencem ao universo doméstico do fotógrafo, por serem os espaços de moradia e trabalho. Há também outras cidades que estão presentes apenas a partir de 1905, 
percorridas devido a compromissos profissionais como São Paulo, Belo Horizonte, Ouro Preto e Mariana onde foram produzidas pouquíssimas imagens.

Como viagem exclusivamente de lazer, temos uma estadia pontual em Cambuquira em 1908 e outra em 1913, no continente europeu. A viagem de 1913 foi importante por ter marcado mudanças e introduzido, em suas fotografias, o problema da cidade como artefato, monumento, sendo pela primeira vez representada a família no espaço público ${ }^{58}$.

\section{Equipamentos}

Ao longo deste corte cronológico, vários equipamentos foram utilizados e tiveram implicação no produto final. As primeiras imagens foram realizadas com máquinas fotográficas de grande dimensão confeccionadas em madeira, com negativos de vidro, já no processo placa seca. Mas apesar dos notáveis avanços empreendidos a partir da década de 1890, em relação às técnicas que substituíram o trabalhoso processo do colódio úmido, havia ainda certa dificuldade para operar esses aparelhos.

Das câmeras encontradas no acervo Alberto de Sampaio e que foram certamente utilizadas nesse momento temos a Perken, Son \& Rayment, fabricada entre 1892-1899 na Inglaterra, que permitia o uso de negativos de vidro (placa seca) de $10 \times 8,5 \mathrm{~cm}, 12 \mathrm{x}$ $10 \mathrm{~cm}, 16 \times 12 \mathrm{~cm}^{59}$. Para a realização de tomadas externas ainda era preciso carregar a câmera cujo corpo era confeccionado em mogno, madeira padrão utilizada nesse momento, e os pesados negativos - os mais utilizados por Sampaio eram no maior formato - que ficavam acondicionados separadamente em magazines de madeira. Era

\footnotetext{
${ }^{58}$ Em 1912, dois filhos de Alberto de Sampaio, Álvaro e João, ficaram por um ano em tratamento em Leysin, na Suíça. Sampaio, em 1913, vai para Europa buscar esses dois filhos e aproveita a ocasião para fazer a viagem. Levou com ele a esposa Cecília e mais um dos filhos do casal, Bento. Essa foi a única vez que Sampaio esteve no Exterior.

59 Georges Eastman House, Photographic Collections online. Disponível em: http://www.geh.org/fm/lol/htmlsrc/lol92_sum00001.html.
} 
necessário também dispor de uma maleta de couro que servia para o transporte desses negativos (material que não foi preservado no conjunto do acervo).

Essa foi provavelmente uma das primeiras câmeras de Alberto de Sampaio, muito empregada na primeira década do século XX. Isso significava certa dificuldade para a realização das fotografias, devido ao tamanho do equipamento e peso das chapas de vidro, que precisavam ser transportadas e, ainda, havia o tripé necessário para dar suporte à câmera no momento da realização da tomada. É preciso destacar que a pequena quantidade de fotografias realizadas no século XIX se deve, em parte, a essas restrições.

Uma segunda câmera utilizada por Sampaio foi a The Sanderson, também produzida na Inglaterra, cujo modelo era chamado "tropical"60, lançado em 1904, e que fazia parte de uma linha denominada pela empresa como "Hand and Stand" Essa câmera já trazia algumas diferenças, pois era produzida para atender também aos objetivos da fotografia de arquitetura ou simplesmente, por sua portabilidade, para ser usada em viagens, como se referiam suas propagandas. Tinha um mecanismo que permitia fazer movimentações com a lente, tanto no sentido vertical como horizontal, pois a parte do fole (um tipo de sanfona confeccionado em couro que unia o corpo da máquina à parte frontal onde estava a lente), ao invés de ser fixa dispunha de um sistema de parafusos e encaixes que permitiam tal mobilidade. Era mais fácil colocar a imagem em nível - vinha inclusive com um pequeno mecanismo acoplado à base da câmera, um tipo de suporte com uma bolha d'água para atender a esse fim - e acertar o

\footnotetext{
${ }^{60}$ Esse modelo "tropical" só se diferenciava dos demais produzidos pela The Sanderson devido à madeira utilizada para compor a estrutura da câmera, a chamada "Teak" da índia, e ao tipo de latão empregado para fazer a fixação entre as partes, pois o objetivo era permitir que o material não se deformasse em regiões de grande umidade. De alguma forma, contudo, a fotografia servia também como suporte, ou melhor, um meio para dar visibilidade à expansão colonial, uma vez que, pelas propagandas da empresa, observamos a menção aos "trópicos" em relação apenas à Índia e as demais colônias inglesas. Disponível em: http://www.earlyphotography.co.uk/site/sanderson.html.
} 
foco, pois dispensava-se, nesse caso, a movimentação do equipamento, uma vez que tudo era realizado pela parte móvel da câmera.

A The Sanderson era também mais leve, tendo magazines para fotografias em 10 x 8,5 cm. Mas a maleta utilizada para o transporte do material ainda apresentava alguma dificuldade de transporte. Isso porque cada magazine de madeira servia para acondicionar dois negativos de vidro, e na maleta cabiam 12 ao total, o que representava certamente um grande peso, pois se carregavam 24 negativos de uma só vez. Mesmo assim, havia um avanço considerável, pois nesse caso dispensava-se o uso de tripés, também devido ao mecanismo de nivelamento existente no equipamento.

No Brasil, sabemos que havia diversas dificuldades de adequação dos equipamentos, que eram todos produzidos para os países do hemisfério norte. Maria Inez Turazzi (2002: 27), por exemplo, destaca que Marc Ferrez apenas se baseava nas tabelas encontradas nos manuais de fotografia e de equipamentos estrangeiros, utilizando os dados como uma referência para produzir suas próprias conversões, as quais seriam adaptadas às condições de iluminação encontradas em nosso país. Expor negativos e revelar fotografias exigiam, em termos técnicos, procedimentos locais, por isso, a The Sanderson modelo "tropical" certamente deve ter tido aqui boa expansão de que é pista o emprego freqüente por Alberto de Sampaio.

Outra câmera utilizada a partir de 1906 foi algum dos modelos comercializados pela Kodak, possivelmente a Folding Pocket Kodak. Como esse equipamento não pertence ao material que ficou preservado em seu acervo pessoal só temos a informação sobre sua utilização porque o próprio Sampaio deixou anotado em seu caderno de anotações algumas imagens com a referência "Kodak" - nesse caso são negativos de vidro 10 x 8,5 cm. Ainda há o próprio suporte em celulóide que foi utilizado para fotografias realizadas na cidade do Rio de Janeiro em 1906. Isso indica que ele tinha 
pelo menos dois tipos de câmera desse fabricante, que podia utilizar tanto celulóide como vidro. Essa câmera, entretanto, não foi extensamente utilizada. Sampaio tinha preferência pelos negativos de grande formato e principalmente pela The Sanderson.

Outra câmera adquirida nesse período foi um dos modelos da empresa inglesa Newman \& Guardia. Muito provavelmente Sampaio utilizava a Baby Sibyl lançada a partir de 1912 e que trazia diversas novidades: tinha corpo em metal, negativos menores e muito mais finos de 6 x 4,5 cm. Era bem mais leve, pesando somente 270 gramas, e, ainda, permitia maior abertura do diafragma (o que possibilitava a realização de fotografias em condições de iluminação precárias), facilitando a utilização em espaços externos. Possivelmente, Sampaio adquiriu esse equipamento no período de sua viagem à Europa, pois só há imagens nesse formato a partir de 1913. Encontramos então poucos os registros dentro do corte cronológico aqui estudado.

Há também uma câmera estereoscópica que ainda pertence ao acervo, a StéréoPanoramique Leroy, produzida na França a partir de 1906, cujos negativos eram de vidro no formato $12 \times 6 \mathrm{~cm}$. Apesar de mais leve, em metal e com pequeno formato, Sampaio utiliza muito pouco esse equipamento. Praticamente são inexistentes imagens realizadas até 1914, o que é de se estranhar, pois sabemos o quanto esse tipo de câmera era popular entre determinado segmento amador. Certamente, não aquele formado pelo Photo-Club do Rio de Janeiro, que mantinha altas pretensões artísticas em meio a acirrados debates estéticos. Gavin Adams (2004: 90), em seu trabalho sobre estereoscopia no Brasil, identificou diversas coleções particulares e evidenciou o quanto o sistema se difundiu entre nossos amadores, nas primeiras décadas do século $\mathrm{XX}$. No grupo pesquisado, os fotógrafos eram, em geral, homens de elite, com profissões liberais, e tinham certo descompromisso com questões estéticas, se aproximando no uso da imagem, da linguagem turística. Vale ressaltar que o próprio fotógrafo amador que 
foi o maior companheiro de Sampaio nesta atividade, Otávio de Oliveira Castro, tinha predileção pela estereoscopia, como pode ser comprovado pelo acervo que foi preservado pelos seus familiares.

Alberto de Sampaio utilizou, pois, diversos modelos de câmeras fotográficas, acompanhando as mudanças que ocorriam de maneira geral, tendo equipamentos de uso amador e outros produzidos para os profissionais. O material que acabamos de listar contém apenas aquelas máquinas que ficaram preservadas em seu acervo pessoal. Há ainda fragmentos de negativos e magazines, que indicam a existência de outros equipamentos. Todos esses materiais revelam que Sampaio dispunha de amplo conhecimento técnico e fez grande investimento econômico. Ele tinha, inclusive, laboratório próprio, em sua residência em Petrópolis, essencial para os procedimentos de revelação e ampliação fotográfica.

Por fỉm, em relação à mudança de uso das câmeras, ao longo do corte cronológico aqui estudado, é possível estabelecer uma divisão geral: encontramos negativos de grande formato, da câmera mais antiga, utilizados de forma predominante na primeira década de sua atividade. Depois, temos maior diversidade, com chapas menores e mais finas, negativos de celulóide etc. Porém, tal divisão não se estabelece em todas as circunstâncias. No ambiente doméstico, por exemplo, Sampaio continua a utilizar preferencialmente negativos de 12 x $16 \mathrm{~cm}$ (aproximadamente), provenientes de câmeras como a Perken, Son \& Rayment e a The Sanderson que, além das fotografias na residência possibilitava os passeios, sendo muito utilizada para registros da natureza e em viagens. Já a Kodak, como as próprias propagandas diziam, servia para registros “outdoors”. Devido à sua portabilidade, é com essa câmera que Sampaio produz suas primeiras imagens urbanas, registrando acontecimentos no Rio, desde festividades até tomadas ocasionais nas praias. Anos mais tarde, já de posse da Newman and Guardia, se 
intensificariam as tomadas urbanas, na viagem a Europa. A câmera mais leve e com os pequenos negativos de vidro, unia praticidade e qualidade das imagens.

\section{Álbuns}

Os álbuns reafirmam o grande investimento pessoal de Alberto de Sampaio com a fotografia. A tomada era apenas a parte inicial de um processo mais amplo, que exigia domínio técnico laboratorial (para os procedimentos de revelação e ampliação) e organização posterior das imagens produzidas. O conjunto tem um sistema complexo de organização, que não será explorado aqui, já que nosso propósito não foi estudar o acervo em si, mas utilizá-lo para a compreensão mais ampla da cultura amadora. Porém, há alguns elementos fundamentais, que merecem ser destacados, porque, a partir deles, pudemos extrair dados biográficos e cronológicos das fotografias. E daí compor séries temáticas próprias para atender aos objetivos da pesquisa.

Destacamos inicialmente os critérios adotados por Sampaio. Ele estabelece tratamento diferenciado entre os dois conjuntos: os álbuns de uso da família, que denominamos ser de "exposição"; e outros de arquivamento. No primeiro eixo, há poucos álbuns temáticos: a) os que trazem séries (3 volumes), predominam o registro de pessoas e paisagem; b) a maioria está relacionada às imagens da Europa (10 volumes), em que o tema é a viagem, e englobam uma diversidade de situações, registradas entre abril e junho de 1913 - estes álbuns contêm textos escritos e longos títulos para as fotografias; c) o Rio de Janeiro também mereceu um único álbum, pequeno, em 1906, que contém os primeiros registros urbanos da cidade e das praias. E, ainda, temos os álbuns panorâmicos (13 volumes), que reúnem a quase totalidade acervo produzido. Unitariamente temos grande quantidade de imagens. Todos eles têm capa preta de couro, com folhas internas em papéis da mesma cor. Em cada página, há algumas 
legendas e numeração. Aqui a questão principal é a mobilidade, pois o álbum permitia incluir novas páginas e tirar antigas (eram furadas, presas com parafusos). Tal procedimento ainda permanece no uso que os descendentes de Sampaio fazem desses volumes.

No segundo eixo, encontramos os álbuns de arquivamento e catalogação ${ }^{61}$, que foram fundamentais para nossa pesquisa. O conjunto foi formulado para uso específico do próprio fotógrafo. Por isso, as imagens foram reveladas sem grandes preocupações com enquadramento, disposição na página etc. A questão principal era o sistema elaborado, que tinha como objetivo permitir a recuperação de dados sobre as fotografias. O sistema tomava por base o tamanho dos negativos. Havia conjuntos de 18 x $13^{62} \mathrm{~cm}$ (3 volumes); de $10 \times 8,5$ (9 volumes); e de $6 \times 4,5$ (dois volumes). Nos álbuns, cada fotografia tinha um número carimbado na própria página, junto à imagem. O mesmo número era colocado no envelope que envolvia os negativos de vidro, permitindo assim encontrar o original. Porém, havia outra numeração escrita com caneta especial no próprio suporte do negativo, que, por sua vez, coincidia com os dados textuais da referida fotografia, anotados no caderno de catalogação. Esse caderno é um documento muito importante porque contêm os títulos das imagens, atribuídos pelo próprio Sampaio, com indicação de data e tamanho do negativo. Há duas listas: uma primeira cobre os anos de 1888-1914 (10 x 8,5 cm) e a segunda de 1896-1914 (18 x 13 $\mathrm{cm})$.

Porém, o sistema de armazenamento do caderno não engloba o total da produção do período. Trata-se apenas de uma parte que foi selecionada por Alberto de Sampaio.

\footnotetext{
${ }^{61}$ Havia ainda um último caderno comum com o título de "Diário", que contém muitas imagens bem pequenas, coladas aleatoriamente. Em algumas delas, do início da atividade do fotógrafo, o negativo foi perdido e não se encontra nem mesmo nos álbuns de catalogação. Por isso, é difícil fazer estimativa precisa da produção deste fotógrafo nesses anos. Trabalhamos com registros que são indicativos do foi realizado, porém, essa mostra é representativa do total produzido.

${ }^{62}$ É importante ressaltar que nos álbuns de $18 \times 13 \mathrm{~cm}$ há também incluídos negativos menores de $15 \mathrm{x}$ $12 \mathrm{~cm}$, embora não existam referências escritas a esse segundo tamanho. Sampaio apenas escolheu a maior dimensão como padrão.
} 
Das imagens que ficaram fora da catalogação do caderno, há outro conjunto de negativos de vidro que trazem excepcionalmente inscrições. Sampaio escreveu a data, o nome do equipamento e outros dados técnicos em 132 chapas.

\section{As séries temáticas}

Como já dissemos, trabalhamos com séries que são capazes de fornecer matéria para a problemática a ser analisada na pesquisa. Iremos tratar de atributos que dizem respeito às questões aqui investigadas, utilizando imagens-tipo. Por isso, é importante ressaltar que estas séries não esgotam o acervo, nem foi esse nosso objetivo. Apenas reunimos um conjunto de fotografias (1000 imagens, das quais 886 há identificação) que nos permitiram melhor entender a cultura amadora entre os anos de 1888-1914. Dentro desse período, são três eixos destacados que estão relacionados tanto à determinadas ocorrências no acervo como fazem parte da orientação cultural referente aquilo que capitalizava os debates no campo fotográfico: Natureza (paisagem); Espaço doméstico (família); Cidade (espaço público).

"Natureza (paisagem)" será nosso primeiro tópico a ser analisado. Isso porque há, em termos quantitativos, um predomínio desse eixo temático, seja de forma isolada, seja em relação à presença humana. Podemos estabelecer diversas mediações, ou mesmo gradações, da relação do homem com seu espaço natural. O problema da representação da natureza, central para o acervo de Alberto de Sampaio, era também um elemento significativo na produção de imagens do século XIX, no campo da fotografia assim como da pintura.

"Espaço doméstico (família)” se refere aos registros, que, no caso do amador, eram realizados preferencialmente em sua residência. Alberto de Sampaio tem extensa produção desse tipo de imagem - que quase sempre pode ser tratada como retrato - e 
que representa a segunda maior ocorrência dentro do acervo. Num momento de ainda grande comercialização de retratos produzidos por profissionais em estúdios, os amadores introduzem outros elementos que dialogam e mesmo se opõem àquilo que consideramos como uma questão central para a fotografia no século XIX: a pose como uma forma de auto-representação.

"Cidade (espaço público)" é o eixo em que temos a menor quantidade de imagens. Nesse caso, trata-se de uma produção que se acentua no século $\mathrm{XX}$, tendo como ponto inicial o Rio de Janeiro com suas primeiras manifestações da modernização empreendida no período Passos. De fato, a cidade não constituía, de forma geral, um tema importante para o cânone estético no século XIX, compartilhado nos clubes de fotógrafos amadores. Havia muito mais atenção e, por certo, certa exclusividade de temas a serem abordados na literatura especializada do período, para o retrato e a paisagem. De maneira geral, os registros de cidades não estavam incluídos nos espaços das exposições ${ }^{63}$. Mas apesar dessa não prevalência, Alberto de Sampaio produz algumas poucas séries de fotografias urbanas significativas que nos deixam entrever contradições existentes não apenas no campo fotográfico, mas também na sociedade na qual ele estava inserido.

\footnotetext{
${ }^{63}$ Nos novos estudos sobre fotografia amadora relativiza-se a predominância do modelo pictorial, como sendo central para os amadores de fins do século XIX. Por exemplo, Cristian Joschke (2005: 297) demonstra que diversos membros de clubes de amadores na Alemanha produziram fotografias de caráter documental, de cidades e de costumes, que passaram a integrar o acervo de diversas instituições naquele país.
} 


\section{NATUREZA (PAISAGEM)}

No acervo Alberto de Sampaio a natureza constitui um eixo temático de alta importância, em termos quantitativos: são 274 fotografias. Há aqui divisão entre dois momentos da produção de Sampaio: o primeiro entre 1888-1905, com apenas 59 registros; já nos anos 1905-1913 foram produzidas 215 imagens.

No caderno de anotações de Alberto de Sampaio, na terminologia empregada pelo próprio fotógrafo, a natureza é referida, preferencialmente, a partir de seus elementos constituintes, como árvores e rios, que então funcionava como componente da temática principal. Em outras circunstâncias, em que aparecem construções há, em raros casos, títulos como "panoramas" ou "vistas", enfim, referências a tomadas mais amplas em que o fotógrafo se apresentava distanciado de seu objeto. Isso porque, como veremos, inserir-se diretamente no espaço fotografado era uma característica das tomadas de Sampaio, assim não havia interesse em promover afastamento, nem mesmo de forma nominal, de seus objetos de interesse.

Tudo isso ocorria dentro de um contexto de extrema valorização da natureza, seja pelo cânone da fotografia com objetivos artísticos, de certos clubes de amadores, seja na pintura de paisagens, ou mesmo literatura. Havia, por certo, um problema de caráter geral, já antigo, de afastamento das cidades e valorização dos espaços naturais que promoviam compensação para perdas e transformações ocorridas no espaço urbano, sobretudo no caso europeu. Mas no Brasil, país em que apenas poucas regiões haviam de fato se urbanizado, tal problemática terá conteúdos diversos. 
As artes plásticas da virada do século XIX, por exemplo, incorporaram fortemente debates de conteúdo identitário. Era na representação da luz tropical, de nossa vegetação, dos homens do campo, enfim, de tudo que estava afastado da vida da grande cidade que os principais escritores que tratavam da temática iriam pautar suas discussões. Havia proposições que tinham como objetivo, além de promover a observação cuidadosa das condições locais, estabelecer distância crítica de correntes estéticas estrangeiras (Cf. Valle; Dazzi, 2009: 122) .

Na fotografia, tal preocupação não seria incorporada ao que era discutido, por exemplo, nas revistas ilustradas. O caráter amador dos integrantes daqueles clubes, aqui e no exterior, teria como conseqüência o total afastamento do problema crítico. O que mais importava eram os debates sobre a composição do quadro (distribuição de planos, perspectiva, etc), o uso adequado da iluminação, a dimensão tecnológica com as constantes novidades sobre os equipamentos, materiais de laboratório, etc. A representação da natureza, nestas circunstâncias, seria um tópico muito apreciado, pois era um meio de fruição estética e possibilidade de afirmar conhecimentos de homens de perfil burguês. Não se trata aqui da natureza capaz de fundamentar uma identidade, mas um gosto.

Petrópolis era espaço privilegiado para a elite que vivia a Belle Époque na capital do país. Do mesmo modo, lugar propício para a mediação entre natureza/cidade, seja na produção dos fotógrafos amadores ou profissionais que divulgavam suas imagens de árvores e rios, em exposições e revistas ilustradas. Alberto de Sampaio terá concentrada na cidade serrana a maior parte de sua produção de fotografias da natureza. Porém, devido à pertinência do eixo temático, a natureza está numa diversidade de lugares e situações: cidades visitadas no interior do Brasil (englobadas pela natureza) e Europa (predominam representação de grupos na natureza), além dos registros nas 
fazendas de familiares. Vale ressaltar que a cidade não se apresenta como artifício, com sinais de intervenção humana, próprio do espaço urbano. Trata-se de uma natureza que invade a cidade e se torna hierarquicamente preponderante.

Para o tratamento e estudo deste eixo temático dividimos as fotografias em sete séries que representam uma gradação no diálogo do homem com a natureza:

- "natureza como objeto de estranhamento/desfrute" (54 fotografias) que trata da natureza como alteridade, algo diverso do que a experiência cotidiana de habitar favorece e, assim, é procurada para gozo e desfrute.

- "natureza como mobiliário cênico" (28 fotografias), quando árvores, rios e outros elementos constituem apenas fundos para as imagens sem haver nenhuma relação mais específica;

- "a cidade imersa na natureza" (22 fotografias), trata da cidade quando há domínio e preponderância do espaço natural, com poucos sinais de ser artefato, objeto de intervenção humana;

-“natureza como força poderosa (7 fotografias), que lida com contrastes, aquilo que na natureza submete o homem;

- "o bosque" (37 fotografias), são espaços pequenos, próximos, sendo esta a série temática com mais unidade em todo o conjunto e que evidencia as escolhas e preferências do fotógrafo;

- "campo" (103 fotos), atividades significativas do modo de vida que se opõe à cidade e quando a natureza é observada com interesse de tipo etnográfico;

- "paisagem industrial” (23 fotografias) com registros de áreas com predomínio da natureza, mas contendo elementos indicadores das transformações por meio da tecnologia ou exploração do espaço. 


\section{A natureza como objeto de estranhamento/desfrute}

Nessa série identificamos as fotografias relacionadas à fruição aqui entendida a partir da ação de “ir ver” a natureza. É quando o deslocamento e atividades como piqueniques, passeios e caça se tornam no pretexto principal para a realização da imagem. Há diversos graus nesse processo de estranhamento/desfrute e por isso dividimos a série em duas: homem/natureza (onde essas questões se apresentam de forma mais relevante) e natureza em si. Nota-se maiores transformações nas formas de interação estabelecidas entre o homem e a natureza, na produção do século XIX e XX. Mas no caso das vistas do mar e rios - no item natureza em si, em que não há presença humana - temos continuidades, tanto de caráter temático como morfológico.

A primeira fotografia realizada por Alberto de Sampaio em 1888, segundo a legenda do fotógrafo, registra um "Pic-nic na Gávea" (Fig. 1), e privilegia a relação estabelecida entre homem/natureza. Trata-se de um grupo formado por amigos, com a presença do próprio Sampaio, num momento em que ele tinha apenas 18 anos. Segundo seu caderno de anotações, essa seria a primeira fotografia por ele realizada, mesmo ano em que ingressou na faculdade de Direito no Rio de Janeiro. Certamente, o fotógrafo foi responsável pela organização da imagem e outra pessoa fez o clique final. Mas devemos considerá-la do próprio Sampaio uma vez que está documentada em seu caderno de anotações.

Nessa fotografia o interesse se circunscreve à natureza, sobretudo pelo valor atribuído a ela como coisa visual. O evento servia para estar nesse lugar (Gávea) e tratase de um passeio. A natureza fornece assim oportunidade para o exercício de composição. O que importa é a relação entre o banco, as pessoas e o galho que serve de suporte para o homem. 
É importante destacar que nessa imagem não há dramaticidade e, por isso, a natureza aparece como pano de fundo, uma característica que se mantém até pelo menos 1904-05 nas fotografias de Alberto de Sampaio. Tal relação evidencia alguns elementos de um tipo de interesse pela natureza herdado do século XIX, que poderia ser local de descanso, espaço de amenidades, onde as elites podiam se refugiar da vida conturbada da cidade. A própria região é significativa do modo de ocupação urbana ocorrido no período.

O Rio de Janeiro foi uma das únicas capitais do país, desse período, que tinha as classes sociais mais privilegiadas morando fora do centro da cidade, em arrabaldes próximos às montanhas e vales. Esse hábito revela muito da presença estrangeira que deixou traços significativos no modo de viver da população carioca. De fato, desde os primeiros anos do século XIX os estrangeiros preferiam as localizações mais distantes, devido ao desejo de estar longe do centro conturbado, com sua feição de cidade colonial, ou mesmo por desenvolverem nesses locais lucrativas atividades econômicas como o plantio do café. Se a família real habitava em São Cristóvão, já situada fora do centro urbano, os franceses seguiriam em direção à Tijuca que ficou conhecida como lugar de moradia dos Taunay. Já os ingleses, grupo formado por diplomatas e comerciantes, se direcionavam para as regiões da Gávea. Esses estrangeiros, como destaca Flavio Villaça (1998: 165), transplantaram "para o Rio uma forma de morar européia ainda herdada do século XVIII".

A primeira linha de bondes, inaugurada no Rio de Janeiro, viria ligar exatamente o bairro da Gávea ao centro, em 1858, o que revela não só a densidade da região, mas também sua importância em termos econômicos (Santos, 1996: 193). Só depois seriam construídas linhas de bonde em bairros como Flamengo e Botafogo. Nesse novo vetor de crescimento urbano, as grandes chácaras estavam voltadas para as áreas 
montanhosas, da mesma forma que as primeiras ocupações de estrangeiros no Rio de Janeiro (Villaça, 1998: 169).

A fotografia "Pic-nic na Gávea" revela esse tipo de ocupação e divertimento característico das elites formadas a partir da segunda metade do século XIX, até mesmo por sua localização geográfica. Nesse contexto, a natureza não aparece como algo que emocione, comova e desperte sentimentos, mas um lugar onde se pode desfrutar de determinados momentos, ou local em que essas pessoas mantinham suas habitações (veraneio ou residência principal).

Tal percepção começa a se alterar nos primeiros anos do século $\mathrm{XX}$, quando Sampaio realiza, preferencialmente, fotografias de indivíduos em meio à vegetação. Imagens que terão características distintas: podem tanto servir para documentar uma ação como também se prestar ao diálogo mais explícito com certa visão pitoresca da natureza, como lugar de contemplação, herdada de suas referências estéticas.

A fotografia de 1906 (Fig. 2) em que Sampaio registra seu cunhado, o fotógrafo amador Otávio de Oliveira Castro num rio em Petrópolis, representa uma forma de mediação entre essas duas perspectivas: por um lado, dialoga com os registros do século XIX em que a natureza está lá como lugar onde se desenrola a atividade - ele sai para fotografar - e, por outro, o homem aparece envolvido pelo espaço, tomado pela vegetação que praticamente invade o solo, se misturando com a água e a parte superior da cena. Mas ele, o homem, não está arrebatado pela natureza nem dominado por ela. Trata-se de um fotógrafo que segura seu equipamento de maneira firme e olha diretamente para a câmera. Sinal de que essa natureza seria convertida em imagens, como foi a própria fotografia de Sampaio.

Esse registro indica também outra mudança. É no início do século XX que a natureza se transforma em objeto central nas fotografias de Alberto de Sampaio, 
ocupando papel de destaque as representações de massas de vegetação. Os recursos técnicos também se aprimoram, permitindo, agora, valorizar áreas com sombras, outras com luz mais intensa e reflexos que exploram as próprias folhas e galhos para obtenção de contraste. Como veremos adiante, será a partir desse momento que a natureza irá converter-se em personagem principal, o que se explicitará inclusive nos títulos dados para as imagens pelo próprio Sampaio.

Alguns fatores serão decisivos para tal alteração de perspectiva. Um dos mais importantes, certamente, era a forte orientação cultural existente nos clubes e publicações direcionadas aos amadores, que valorizavam a prática de excursões. Eram "passeios" de grupos de elite que promoviam interação social, atuando como elementos de diferenciação, tanto dos que se vinculariam ao debate estético como ao uso de câmeras simplificadas.

Cumpre ressaltar que a prática da viagem ou mesmo o termo excursão já era adotado desde a fase inicial de difusão da fotografia, quando ainda era necessário utilizar os negativos em colódio úmido, junto a todos os recursos materiais necessários para fazer a revelação na hora da tomada da imagem. A novidade de fins do século XIX, contudo, estava no fato de haver institucionalização da atividade por grupos que utilizariam a fotografia como mediação entra a cultura científica e a artística. Prática que também estaria vinculada a outras instituições que partilhavam de interesses comuns como museus e centros de pesquisa na Alemanha, Bélgica, França e Inglaterra. Havia inclusive a criação de clubes específicos voltados para a excursão, tornando o vocábulo numa expressão corrente, que fora apropriada de diversas maneiras nas publicações do período ${ }^{64}$.

\footnotetext{
${ }^{64}$ A diferenciação entre aqueles clubes de fotografia, que já apontamos genericamente, merece ser ressaltada. Havia uma cisão conforme nos indica Michel Poivert (2001: 18) entre os clubes de amadores ligados de forma primordial à questão estética, como era o caso do Photo-Club de Paris, e outros formados por fotógrafos como Albert Londe, que era médico e unia na atividade fotográfica curiosidade
} 
Mas nosso único Photo-Club, no Rio de Janeiro, tinha como modelo o PhotoClub de Paris, sendo estas duas associações, espaços propícios para as discussões estéticas. Por isso, não teríamos aqui nada semelhante ao que ocorria nos países europeus. A imagem do fotógrafo no meio da mata, no entanto, nos mostra um diálogo com essas idéias em voga, que se traduziam apenas como um tipo de incentivo para fazer registros variados por meio de um passeio informal, realizado por dois fotógrafos amadores. Incentivo importante para que as fotografias de natureza de Alberto de Sampaio deixassem de estar exclusivamente relacionadas a eventos ligados aos grupos familiares.

Nesse mesmo ano de 1906, Alberto de Sampaio adquire uma câmera Kodak e com ela realiza as primeiras fotografias do bairro de Copacabana em que aparecem alguns de seus familiares. Poderíamos pensar numa continuidade entre as fotos de pessoas em áreas de vegetação densa e os registros da praia. Mas não foi isso que aconteceu. As imagens de Copacabana nos trazem elementos diferentes. Nesse passeio (Fig. 3), Alberto de Sampaio se afasta em parte daquilo que estava sendo discutido no Photo-Club, recém inaugurado no Rio de Janeiro. As fotografias são ocasionais, sem grandes pretensões artísticas, sendo apenas um registro de seus filhos, sobrinhos e do cunhado Otávio de Oliveira Castro. A alteração foi importante e está relacionada a duas questões principais: o problema do equipamento e do espaço registrado.

No caso, é preciso destacar, em primeiro lugar, algumas questões relacionadas à difusão da Kodak que, em suas propagandas nos primeiros anos do século XX, como bem demonstrou o trabalho, já referido, de Nancy West (2000:37), associava a prática da fotografia à idéia de diversão sem estar totalmente vinculada à função de memória

visual ao interesse científico, nas palavras de Tom Gunning (2006: 84). Isso não significava que para os excursionistas as questões plásticas não fossem importantes, mas, antes de tudo, que havia a possibilidade de contaminação dentro do espaço amador de elementos cuja visualidade não estava embebida exclusivamente em algum tipo de diálogo pictórico. 
para o grupo familiar - que mais tarde se tornaria um eixo central de seus reclames. Esse "lazer" totalmente sem compromisso, nem mesmo com domínio técnico ou estético da atividade, associava-se, por meio de reclames e imagens, à valorização de certo afastamento dos centros urbanos. Sob outra perspectiva havia aqui a mesma questão da natureza como lugar de compensação daquilo que se perdia com o processo de industrialização, situação de fato muito característica da sociedade americana e facilmente percebida pelos potenciais consumidores desse equipamento naquele país.

No contexto em que se popularizaram práticas ao ar livre e clubes para as atividades de camping, a fotografia se tornará, por meio das propagandas, também como uma "naturalized part of the camping experience". A situação era tão significativa que a autora ressalta que o próprio desenvolvimento técnico dos equipamentos seria condicionado por essas questões. O Kodak Tank Development, lançado em 1905 (tanque cilíndrico de metal para revelação de negativos), se assemelhava muito mais a um equipamento de camping (Ibid.).

No Brasil, no período analisado na pesquisa, não encontramos propagandas da Kodak em revistas nacionais. Há apenas menções, por exemplo, na Leitura para todos, a outros equipamentos para amadores. Mas nas revistas estrangeiras que circulavam por aqui, conforme apontamos, havia diversas propagandas dessas câmeras e os equipamentos eram facilmente encontrados. O próprio Alberto de Sampaio utiliza a câmera Kodak, o Kodak Tank Development e diversos outros acessórios que possibilitavam realizar todo o processo dispensando o laboratório. Ele dispunha, inclusive, de prensas em madeira que permitiam fazer a revelação da imagem no papel fotográfico, utilizando apenas a luz solar. Por isso, a forma com que Sampaio fotografou sua família na praia, dialoga com alguns dos conceitos associados ao uso deste equipamento. 
Em segundo lugar, é preciso considerar que essa representação da praia tem como componente a relação estabelecida com esse espaço. Alberto de Sampaio fazia parte de uma geração que havia aprendido manter certa distância do mar. Ele estava próximo dos morros e da vegetação, pois residia em Petrópolis mas escolheu como lugar para sua primeira fotografia a região da Gávea. Nesse caso, trata-se de um bairro onde havia outros conhecidos freqüentadores de Petrópolis, membros efetivos do próprio Club dos Diários, que ali mantinham suas residências principais no Rio, como Quintino Bocaiúva e Visconde de Ouro Preto (Cf. Villaça, 1998: 168 ). Havia um comportamento geracional de valorização dos vales em detrimento da praia. Mas a situação estava mudando. Apesar de, em 1906, o bairro de Copacabana ainda estar quase desocupado, já contava com investimentos significativos, mobilizados pela associação entre a Prefeitura, a Companhia de Ferro Carril Jardim Botânico e a imobiliária detentora de diversos lotes na região, a Empreza de Construções Civis. Túneis foram abertos, terrenos loteados, houve construção de linhas de bonde, estações, restaurantes, etc (Pereira, 2007: 8). Nesse período, também de grandes mudanças urbanas no Rio de Janeiro, os hábitos de banho de mar começam se difundir estando associados a questões de saúde e higiene.

A própria Companhia de Ferro Carril Jardim Botânico escrevia poemas nos versos dos bilhetes dos bondes, denominados "conselhos de higiene poética" pela população carioca, pois associavam a praia com bem estar e cura de doenças. Era o lugar para se respirar ar puro, fazer pic-nic, para "fugir da poeira insana" e dos ares tísicos do centro do Rio (apud Berger 1959: 37). Mas ainda estava muito incipiente a associação que se tornaria primordial nos anos seguintes, como bem destaca Sevcenko (2002: 571), entre cultura desportiva e saúde. A situação urbana, no entanto, era precária, as ruas não haviam sido calçadas e nem mesmo contavam com meio fio. Nos 
dias de chuva a população reclamava, pois a região ficava intransitável. A principal via situada na beira mar, a avenida Atlântica, só foi aberta em 1906 pelo prefeito Pereira Passos (Gerson, 1996:322).

Porém, o que aparece nas fotos de Sampaio? Não há nada sobre o espaço urbano, sinais que nos indiquem o crescimento da região, os contrastes ou lugares ainda vazios (Figs. 4; 5). Tudo o que percebemos é o registro da família no imenso areal e quando a arquitetura aparece, é tomada de longe, quase se diluindo com os morros. Certamente, é preciso considerar o fato de que o mar era um lugar estranho, com qual Sampaio não tinha intimidade. Por isso, as dimensões que ficam salientadas na fotografia, podem também atuar como uma forma de compensação, que revela parte desse estranhamento.

$\mathrm{Na}$ viagem ao continente europeu em 1913 (que será tratada mais adiante) notamos outra mudança, e não é só em relação aos equipamentos utilizados. O que se altera é o lugar, a outra cultura, os países nunca vistos mas muito “imaginados” pelas revistas, cartões postais e cinema. A realidade da "Europa" possível de Petrópolis, tão propalada pelas elites que habitavam na cidade serrana, fica para traz. Há aqui a "Europa de fato", com sua cultura amplamente diversificada e voltada para a atividade de "lazer", com forte sistema organizacional. Alberto de Sampaio e sua família se tornam aqui turistas, uma condição que leva a um diferente uso do espaço, cuja partição do tempo é o elemento primordial.

A fotografia de uma praia (Figs. 6; 6.1), em alguma cidade na França (não há indicação precisa do local nem no álbum), revela três questões que se diferenciam das características de sua produção no Brasil: há o instantâneo fotográfico, as pessoas estão de costas e não se trata de um registro da família. Esse é o lugar do lazer como atividade amplamente integrada à sociedade, economicamente rentável, cujas bases eram bastante 
antigas, como destaca Corbin (1995: 83), a respeito das regiões balneárias da França, muito freqüentadas já nos primeiros anos do século XIX. E como vemos na parte direita da imagem, havia ali diversas cabines, para trocar de roupa e pequenas torres de edifícios ao fundo, praticamente aglomeradas. O espaço, ao contrário da praia de Copacabana, é restrito, tomado por todo tipo de construção.

Nota-se que Sampaio registra a mulher, situada na parte esquerda da imagem, enrolada numa toalha. Ele confere assim atenção para a plasticidade da forma e não para o corpo em si. Situação que o diferencia dos amadores usuários de câmeras portáteis, figuras que se popularizavam por ficarem de prontidão para realizar qualquer imagem nos espaços públicos. Os humoristas não perdiam a chance de retratar o "photographe amateur" em tom irônico nas revistas ilustradas, revistas especializadas de fotografia e em cartões-postais ${ }^{65}$. Isso porque esses grupos provocavam diversos constrangimentos e, com isso, surgia a necessidade de formulação de leis para garantir a privacidade (Wigoder, 2003: 354). A Alemanha e EUA seriam os primeiros países a terem uma legislação própria, ainda no século XIX, buscando defender a população dos amadores de "plantão".

O que Alberto de Sampaio percebe nessa praia, porém, não está relacionado a questões de privacidade, mas diz respeito ao problema da representação do movimento. Por isso, a fotografia não registra as pessoas como temática principal, não vemos seus rostos ou nada que nos remeta à identidade. O que temos é a locomoção, o caminhar contínuo; o grupo no primeiro plano olha inclusive para o chão como se procurasse algo. A ação é congelada e ficamos com a indicação de que eles continuam andando. Desta forma, essas pessoas integram o sistema que rege o lugar, numa circulação de grandes massas que vão e vem conforme a estação. O que Sampaio documenta é essa

\footnotetext{
${ }^{65}$ Nas revistas Paris-Photographe, Bulletin Belge de Photographie, The Graphic, Lectures pour tous e, no Brasil, a Leitura para todos, há matérias abordando o problema da privacidade e fotografia. Eram mencionadas as mudanças na legislação, os casos mais curiosos ocorridos, etc.
} 
transmutação, um tipo de espaço de ação contínua que encontraria um equivalente no trem, lugar máximo concebido como de passagem.

E, possivelmente, a Europa vista pelo olhar do turista, cuja estadia em cada lugar visitado é cronometrada previamente, permite a Sampaio representar o problema do tempo inscrito na paisagem. Na fotografia "Photo tomada do wagon do Oberland Bernois em caminho para Chateaux d'oeux - abril de 1913" (Fig. 7) temos a imagem da neve, numa região montanhosa, através da janela de uma locomotiva. Aqui existe apenas a linha indicativa da parte interna do vagão e uma mancha representando a paisagem transformada pelo movimento.

Ora, a percepção de que o trem alterou a forma com que vemos a paisagem aparece já nos primeiros escritos da geração que presenciou a invenção desse maquinário. São conhecidos os relatos de Flaubert e outros escritores que falam de diluição da paisagem quando tiveram suas primeiras experiências como passageiros de trem e, como se sabe, na pintura e no cinema esses efeitos tomaram formas específicas alterando profundamente a atividade artística a partir de então (Sevcenko, 2002: 520). Portanto, não há nenhuma novidade nessa imagem em termos históricos, todavia, é preciso considerar que se trata da representação de uma diferente experiência para Sampaio.

Essas imagens, que tratam de algumas interações entre homem/natureza, trazem marcas da transformação da percepção de Alberto de Sampaio no que se refere ao uso de equipamentos ou na relação estabelecida com o espaço ocupado. Há, portanto, diversificação de materiais utilizados, regiões e formas de apreensão. Tal diversidade, contudo, não ocorre quando se trata do que denominamos "natureza em si". $\mathrm{Na}$ produção da década de 1890, temos apenas vistas de Paquetá (Fig. 8), em que é possível perceber o mesmo olhar, um tanto desinteressado, que produz imagens sem grandes contrastes ou aproximações. Anos depois, a partir de 1905, com as tomadas na praia 
(Fig. 9), como "Vista da Barra" em Copacabana, notamos uma espécie de diálogo com a tipologia pré-fixada, tanto na pintura como na fotografia profissional, que definiam questões como proporção, iluminação, etc. Mas em ambos os casos, tanto nas imagens do século XIX como nas do XX, ele dialoga diretamente com o cânone estabelecido, não trazendo nada de novo para o que denominamos "modo amador de ver". Por isso, podemos dizer que as diferenciações e transformações iram se manifestar com veemência apenas nas imagens que privilegiam as formas de interação estabelecidas entre o homem e a natureza.

\section{A natureza como mobiliário cênico}

A representação da natureza como cenário caracteriza parte da produção de Alberto de Sampaio do século XIX e XX. Trata-se de imagens de amigos e membros da família Sampaio, tendo sempre vegetação e árvores como fundo. Inicialmente, havia predominância do registro de grandes grupos, depois, Sampaio passa a se deter em imagens individuais. Observamos, nessa série, também transformações no grau de interação com o espaço ao longo da produção de fotografias, variando da apropriação instrumental da natureza ao uso humorístico do cenário.

As primeiras fotografias dessa série foram realizadas em 1893: são duas imagens de um grupo misto, de amigos e familiares, na rua do Bispo, local em que Alberto de Sampaio havia nascido e morava no Rio de Janeiro. É a mesma região de crescimento das elites cariocas que foi sendo adensada na segunda metade do século XIX, em direção ao interior, como o bairro da Gávea.

Porém, nesse caso, Sampaio não se deslocou para ver a paisagem, praticando alguma atividade como o piquenique, mas apenas escolheu a natureza para servir de cenário, em detrimento de qualquer elemento urbano. Na imagem "Grupo na mangueira 
(Rua do Bispo) setembro" de 1893 (Fig. 10) temos um espaço amplo, marcado pelo imenso tronco da árvore que serve como eixo e limite para a distribuição do grupo, composto pelo pai, primas e vizinhos de Alberto de Sampaio. Há também a empregada - segurando uma moringa de água e duas taças - que está fora do grupo mesmo quando, na segunda imagem, é integrada ao conjunto (Fig. 11). A proximidade dos corpos indica laços de parentesco e afetivos, certa intimidade compartilhada e por isso tal afastamento é representativo das diferenças sociais, que ficam nitidamente demarcadas na fotografia.

Não se trata aqui de uma "ama-de-leite" negra e escrava, cuja representação iconográfica já foi objeto de diversos estudos, e que será referenciada mais adiante. Temos apenas uma empregada que está numa extensão do espaço doméstico do patrão, na rua em que ele habitava. Por isso, ela aparece como alguém que está lá para servir, segurando os instrumentos de trabalho. Mas apesar de manter com essas pessoas alguns laços, daí sua presença na foto, a inclusão de fato não ocorre no grupo e a empregada permanece distante, mesmo estando inserida nele.

Essas questões estão muito mais presentes nas fotografias do que o problema da natureza, transformada aqui num cenário para retratados que mantêm com o espaço uma relação mínima. De fato, eles não estão ali prontos para o desfrute da natureza, mas simplesmente utilizando-a como um fundo, o que apenas revela a preferência pelo espaço "natural" para a realização da imagem - onde se encontra a vegetação abundante - em detrimento do ambiente doméstico.

A partir do início do século XX encontramos algumas variações. Em 1908 Alberto de Sampaio, numa viagem a Cambuquira, nos mostra um interesse permanente pelos componentes da natureza, utilizando-os de maneira mais acentuada. Procura situações inesperadas, o que pode resultar em efeitos cômicos como "Otávio na árvore" (Fig. 12). No caso, o galho atravessa o caminho e serve de apoio para o também 
fotógrafo amador Otávio de Oliveira Castro. A natureza como mobiliário cênico permite também brincar, fazer um tipo de humor, ou então serve apenas de acessório cenográfico, o que é percebido claramente em “Otávio e crianças na Figueira de Campanha" (Fig. 13). Nessa fotografia ocasional, a árvore é valorizada como elemento central, merece inclusive a identificação, conferindo proporção ao espaço.

Num dos últimos registros, dessa natureza transformada em cenário, se acentua a presença de elementos "naturais" tomados em primeiro plano. Nas duas fotografias “Cecília junto a arvore” de 1911 (Figs. 14; 15), há apenas um fragmento da mencionada árvore, composto pelo tronco - além dele temos ao fundo a cadeia de montanhas da fazenda de Vista Alegre. Nas duas imagens Sampaio dá preferência à esposa nesse ambiente, por assim dizer, mais rústico. Essa impressão se estabelece também pelo entorno composto por vegetação e galhos secos, onde se encontram as luvas deixadas por Cecília. Na segunda fotografia há inclusive um primeiro plano em que os arbustos funcionam como moldura, circunstância explorada pelo fotógrafo para conferir esse efeito que se complementa com a superfície rugosa do tronco.

Há aqui continuidades e diferenças para a primeira imagem de 1893 na rua do Bispo. Os elementos da natureza permanecem privilegiados no espaço externo para a tomada de pessoas. No entanto, no início do século XX, Sampaio está mais interessado no indivíduo isolado, ao invés dos grupos. O cenário, contudo, vai se tornando menos urbanizado, seja pelo destaque conferido à estrutura das árvores, seja pela região escolhida - o campo - e não a cidade. Como observamos na foto da rua do Bispo, o terreno aplainado tem apenas algumas folhas secas caídas no chão, pois certamente ali havia algum tipo de manutenção. Trata-se de um trecho numa rua importante que fazia a ligação da região central com a parte oeste da cidade, por isso, é outro cenário, muito 
diferente das cenas que passariam a ser realizadas no campo, já na primeira década do século XX.

\section{A natureza como força}

Essa constitui a série mais reduzida dentro da produção de Alberto de Sampaio e, em sua maioria, há representação do espaço da praia - temos apenas uma fotografia de pessoas em meio à vegetação. Não observamos mudanças entre uma única imagem do século XIX, realizada em Paquetá na década de 1890, e as demais produzidas entre 1905-10.

Nesse caso há diálogo com o repertório de pintores e fotógrafos profissionais cujas imagens da natureza acentuam elementos como força ou domínio (eventualmente perigo), conduzindo o homem para um estado de recolhimento e reflexão. É desta forma que Sampaio realizou a fotografia "Ipanema" em 1907 (Fig. 16) que, no primeiro plano, destaca as pegadas na areia, direcionando nosso olhar para a pequenina figura humana situada ao fundo, defronte ao mar. Trata-se de um pescador que representa uma pequena e, ao mesmo tempo, expressiva intervenção no cenário. Ele se torna quase imperceptível perante a grandiosa cadeia de montanhas composta pelo Morro Dois Irmãos.

Alberto de Sampaio dialoga aqui com o conceito derivado do modelo estético, ou como alguns autores ressaltam, à poética, presente nas representações da pintura de paisagem do século XIX, muito referenciada como "sublime". O homem é tornado diminuto perante a natureza avassaladora e sua presença não é apenas um recurso para conferir escala ao cenário, mas serve, antes de tudo, para transmitir sensações e sentimentos, revelando a intensidade das emoções.

$\mathrm{Na}$ pintura de paisagem o "sublime" estava associado, na maior parte das vezes, ao elemento água e por isso cachoeiras compunham cenários ideais para a representação da 
natureza que se queria ampla e desconcertante (Andrews, 1999: 136). É preciso destacar que Petrópolis ficava localizada na serra, com seus vales, rios sinuosos e estreitos que tinham nascentes nas montanhas. Por isso, havia diversas cachoeiras, muitas delas próximas ao centro urbano e que foram também fotografadas por importantes profissionais da época. A Cascata do Itamarati, por exemplo, teve um de seus primeiros registros realizado ainda por Victor Frond, que publica seu conhecido livro "Brasil Pittoresco" em 1858. Depois disso Revert Henrique Klumb, Georges Leuzinger, Augusto Sthal, Marc Ferrez e Jorge Henrique Papf documentaram a cascata, o que indica a ampla circulação das reproduções litográficas baseadas em fotografias de Frond e certa "força simbólica" de suas imagens que iriam constituir "emblemas da nação", nas palavras de Lígia Segala (1998: 83). Essa ampla produção sobre a Cascata do Itamarati oscila entre a representação mais "neutra" da cachoeira (Fig. 17) e cenas em que se introduz o problema do "sublime" (Fig. 18), evidenciado pela relação estabelecida entre a figura humana e o entorno.

Fotografias com que Sampaio certamente estava acostumado, seja pela circulação em álbuns, pranchas avulsas ou em exposições nacionais. No entanto, ele deixa de registrar esse local situado na própria cidade em que residia, tantas vezes retomados pelos fotógrafos profissionais, porque não eram esses elementos que mais lhe chamavam atenção ou o que ele mais apreciava na natureza. No máximo, podemos dizer que Sampaio faz um exercício de composição cujas regras foram apreendidas na fotografia de paisagem. Nessa reduzida produção, ele escolhe de forma preponderante o espaço da praia e não as cachoeiras.

É possível ainda afirmar que a valorização da praia como lugar da representação da natureza ampla e poderosa, se deve também ao fato de Sampaio não ter sido educado culturalmente para desfrutar desse espaço. É a única região, portanto, que lhe desperta 
esse sentimento, ou melhor, a apreciação dos contrastes e da pequenez humana face ao cenário natural. O recurso ao "sublime" transforma-se também aqui numa forma de compensação que revela parte desse estranhamento.

\section{A cidade imersa na natureza}

Nesta série há predominância das imagens da cidade de Petrópolis, mas como parte de algo mais forte: a natureza, a topografia, a vegetação. No século XIX temos preferencialmente tomadas realizadas do alto de morros e, depois, a partir de 1905, Sampaio também adota o ponto de vista do transeunte. Essa mudança de perspectiva permite que as fotografias revelem muito mais aspectos da natureza em detrimento do espaço edificado, com as construções totalmente imersas na mata densa.

As primeiras fotografias realizadas por Sampaio, ainda no século XIX, foram tomadas do alto de morros, como "Palatinado visto do morro da Souza Franco" de 1895 (Fig. 19). No bairro, em que o fotógrafo residia, são poucos os sinais da geometria das ruas, como significado do domínio do espaço sobre o homem. O núcleo urbano que havia sido importante para as elites imperiais e que passava nesse momento por um surto de construções e melhoramentos de toda ordem, com recursos provenientes da febre especulatória que assolou a capital do país conhecida como encilhamento, mantinha, segundo esta fotografia, a aparência de um parque calmo e bucólico. Apenas estava pontilhado aqui e ali, de formas construídas pelo homem.

Há também pouquíssimas fotografias dos rios, embora na região eles abundassem. Só temos apenas duas imagens que se vinculam ao mesmo partido das vistas de alto de morros. No "Canal em Piabanha" de 1898 (Fig. 20), por exemplo, as margens do rio foram retificadas e as árvores ordenadas seguindo a lógica instituída no plano urbanístico, empreendido em fins da década de 1840 (momento de fundação da cidade). 
Mas o que Sampaio destaca é certa falta de uniformidade existente dentro daquilo que foi objeto de intervenção, isso porque não se trata aqui de taludes totalmente linearizados por pedras e gramados, como em outras áreas da própria região central. $\mathrm{O}$ que Sampaio escolhe é um pequeno trecho em que tal situação não estava tão evidenciada.

Esse tipo de imagem mantém diálogo com determinada produção de vistas de Petrópolis no século XIX. Algumas questões gerais merecem ser mencionadas, uma vez que diversos fotógrafos estiveram na cidade e registraram por décadas as mesmas áreas. Mas apesar das semelhanças evidentes entre as fotografias, não podemos dizer que a natureza tivesse o mesmo significado e importância durante todo esse período.

É possível aproximar as primeiras imagens de Henrique Klumb e Auguto Sthal, das décadas de 1850 e 1860, com aquilo que Letícia Squeff (2000: 277) muito bem destacou como sendo o forte desejo por parte das elites de integrar "natureza e civilização", no momento de consolidação do estado imperial no plano político e social, quando foram fundadas várias instituições onde seriam debatidas questões como a formação de nossa identidade, nação, etc. Petrópolis, cidade planejada para ser lugar de veraneio do Imperador e da corte, foi transformada, segundo a autora, em "emblema da grandiosidade do Império". Nesse contexto, as fotografias, nesses anos iniciais de ocupação até a década de 1860, ressaltam de forma preponderante o espaço domesticado (Fig. 21), revelando muitos traços das intervenções urbanas. Existem diversas imagens tiradas no nível do observador cuja importância é conferida às ruas, rios retificados e palácios, enfim tudo que remete ao controle do homem sobre a natureza. Em algumas situações, ao invés da topografia acidentada da cidade, são destacados os lugares amplos de áreas no centro, cujos rios aparecem com taludes gramados e árvores ainda pequenas nas margens. 
As fotografias de Georges Leuzinger realizadas em 1867 (Fig. 22) já apresentam intermediação entre o lugar dominado pelo homem e o interesse científico por essa mesma natureza. Ele está imbuído da função de "inventário" e faz também um mapeamento das espécies vegetais - que era atraente do ponto de vista econômico. Sabemos que ele havia colaborado com Louis Agassiz, em sua expedição ao Brasil em 1865 e ainda com Carl Von Martius ${ }^{66}$. Dominava, portanto, uma determinada linguagem que se pautava pela idéia de neutralidade, cientificidade ou aquilo que Sergio Burgi (2006: 155) denominou como interesse no "real". Daí a importância que ele também confere ao registro de áreas ainda com pouquíssimos traços de ocupação, próximas ao centro da cidade de Petrópolis.

Marc Ferrez já estabelece outro tipo de mediação. Há valorização de aspectos urbanos em detrimento da natureza, e, também, a cidade imersa na vegetação. Por isso, destaca as ruas amplas, os palácios e as tomadas das construções do alto de morros e das próprias avenidas (Fig. 23). Para ele, como ressalta Ana Maria Mauad (2000: 397) em relação à produção do Rio de Janeiro, "a cidade surgia na sua totalidade para ser possuída e controlada" o que resultava numa paisagem "ordenada sem evidenciar contrastes existentes naquela sociedade. Situação semelhante pode ser encontrada em Petrópolis, onde encontramos, em certas situações (Fig. 24), domínio da natureza sobre o espaço, em que o próprio Palácio Imperial aparece quase que mergulhado na vegetação densa.

Ernesto Papf e seu filho Jorge Henrique interagem com toda essa produção e estabelecem também vínculos expressivos com a natureza, dando ênfase, muitas vezes, à sua quase supremacia na cidade (Fig. 25). O fato de Ernesto Papf ser também pintor, muito conhecido pelo domínio da técnica da fotopintura nos retratos e também pelas

\footnotetext{
${ }^{66}$ Leuzinger fez fotografias para Louis Agassiz que esteve no Brasil em 1865 e publicou no ano seguinte o livro A journey in Brazil. E também, "aparentemente", para o livro Flora Brasiliensis de Carl Von Martius - publicação iniciada em 1849 e só finalizada em 1906 (Burgi, 2006:152).
} 
paisagens - que segundo Carlos Maciel Levy (1980:26) eram voltadas para aspectos "panorâmicos" das "montanhas" - é indicativo dessa perspectiva adotada. Foi autor de algumas pinturas realizadas em meio à própria vegetação da cidade e fez, junto ao seu filho, muitas fotografias na década de 1880, tanto tomadas no nível do observador como tiradas de alto de morros em que os edifícios aparecem imersos na vegetação.

Algumas dessas fotografias já apresentam semelhanças com a produção de Alberto de Sampaio do século XIX. Porém, diálogos continuariam a se estabelecer com as imagens de Jorge Henrique Papf, realizadas a partir de 1888, quando ele assume o estúdio de seu pai, que se mudara para São Paulo ${ }^{67}$. Certamente, este foi o mais importante fotógrafo de paisagens de Petrópolis, na passagem do século XIX para o XX. Era o profissional mais próximo a Sampaio, conforme já ressaltamos. Sua produção foi extremamente divulgada em diversos suportes, como cartões postais, exposições e revistas ilustradas. As tomadas de alto de morros com formato panorâmico ocuparam um papel relevante em toda sua obra.

Vale ressaltar que a primeira série de imagens que constitui uma vista completa "panorâmica" foi realizada em 1896, sendo formada por oito chapas contíguas que registram o centro de Petrópolis. Esse é o único exemplo de fotografia no Brasil deste período que cobre um ângulo de $360^{\circ}$, como destaca Pedro Vasquez (2000: 126). Um segundo registro pertence a Alberto de Sampaio: são seis cópias em papel (em grande formato), que permitem a visão de $180^{\circ}$ de outra região da cidade (Fig. 26). Em todas essas imagens de Papf há um predomínio das grandes massas de vegetação que praticamente começam a adentrar o espaço das construções. Mas por se tratar de um profissional, há uma diversidade enorme na sua produção: encontramos cenas também

\footnotetext{
${ }^{67}$ Os livros que tratam da história da fotografia no Brasil sempre mencionam que Jorge Henrique Papf havia constituído estúdio próprio a partir de 1899, quando Enersto Papf se muda para São Paulo. Na nossa pesquisa, no entanto, encontramos anúncio de Jorge Henrique nos jornais de Petrópolis já em 1888. Isso significa que ele havia assumido o estúdio fotográfico, mesmo com seu pai residindo na cidade. Então, toda produção da década de 1890 foi realizada pelo próprio Jorge Henrique (Pereira, 2004: 65).
} 
tomadas no nível das ruas, que privilegiam os aspectos urbanos e outras que nos mostram a natureza exuberante, praticamente exercendo controle sobre o espaço.

As fotografias do século XIX de Alberto de Sampaio têm como lastro essa tradição, já amplamente difundida, de realização de fotografias da cidade no alto de morros. Mas a natureza aqui não havia ainda se transformado num motivo central. Essa situação começa a mudar nos primeiros anos do século $\mathrm{XX}$, como observamos na imagem que foi realizada no mesmo lugar que "Palatinado visto do morro da Souza Franco" de 1895 (Fig. 27). Só que agora a cidade está mais imbricada nesse espaço na natureza, pois há inserção da cerca com a vegetação no primeiro plano.

As tomadas realizadas no nível das ruas passam a acentuar também tal relação. A "Rua de Joinville" de 1906 (Fig. 28), por exemplo, que ficava situada próximo ao edifício que havia abrigado o Palácio Imperial, foi registrada sem conferir relevância para as construções suntuosas que ali estavam. Sampaio valoriza a rua em perspectiva, suas árvores ordenadas, porém, há certa homogeneidade estabelecida pelas condições de iluminação. Então, tudo tem certa tessitura composta pela areia, pedras e folhagens das árvores que se confundem com a torre da igreja ao fundo. A arquitetura aqui é tornada um elemento da natureza, ela se integra nesse espaço sem grandes contrastes. Por isso, o animal presente no último plano vem complementar a paisagem, estando totalmente integrado a ela.

O privilégio do domínio da natureza sobre a cidade, que se acentua e vai tomando outras formas no século XX, está vinculado a questões discutidas no circuito amador dos clubes, nesse momento já tendo aqui um forte representante, o Photo-Club do Rio de Janeiro. Nesses espaços, a paisagem constituía o centro principal de interesse, em detrimento da cidade. Ali difundem-se as idéias de que fazer fotografia não era registrar de forma neutra, mas interpretar e realizar, portanto, uma obra pessoal que revelava o 
talento do autor. Esse era um problema central para as artes do período tanto na pintura, literatura assim como nas discussões estéticas travadas entre os amadores de elite. Dentro desse contexto, valorizava-se o autor e seu "ponto de vista" que revelava a originalidade da fotografia. Questões componentes das mudanças ocorridas no campo fotográfico do período e, também, das transformações da própria produção de amadores como Alberto de Sampaio, como iremos discutir com mais detalhes na série seguinte.

\section{O bosque}

As fotografias desta série foram realizadas apenas no século $\mathrm{XX}$, notadamente a partir de 1903, se intensificando entre os anos 1905-09. Trata-se de um conjunto extremamente importante, pois nele identificamos características próprias da percepção de Sampaio, ou melhor, aqui encontramos o que mais parece reunir atributos do que a natureza de fato representava para ele. Daí haver recorrência de determinados padrões e duração significativa da série, cujos próprios títulos das fotografias se referem às árvores, rios e bosques.

A primeira imagem, "Matto no morro", foi realizada em 1903 (Fig. 29). Aqui o fotógrafo está inserido dentro do espaço e não mais observando a paisagem e a cidade à distância, do alto de morros. O título já remete ao tema principal que é a própria vegetação densa, quase num emaranhado, numa fusão de elementos onde se destacam apenas o tronco e pequenos galhos das árvores. A natureza encontra-se no seu estado aparentemente original, cujos sinais de intervenção humana são praticamente inexistentes.

A preferência pela vegetação irá se manifestar nos anos seguintes, porém, com a introdução dos rios como espaço de mediação. A fotografia "Árvore no Piabanha" de 1905 (Fig. 30) é uma imagem típica. Aqui Sampaio explora os elementos escultóricos 
dos galhos, que se contrapõem ao rio estreito e sinuoso. Há atenção para a estrutura da árvore e, por isso, o tronco é tão importante, como também fica ressaltado em "Rio Piabanha", de 1905 (Fig. 31). Apesar de o rio ser o foco (pelo menos é o que indica o título da fotografia), ele tem papel secundário e se transforma numa unidade homogênea pelos efeitos da luz. Como o espaço é fechado, o lugar torna-se acolhedor e a natureza é representada estando próxima da escala humana.

Esse tipo de cena era o que Petrópolis mais oferecia ao observador. Porém, tal representação só ocorre muito tempo depois de Alberto de Sampaio ter-se iniciado na atividade fotográfica - aqui ele já contava com pelo menos 17 anos de prática. Por isso, houve mudança temática e nos conteúdos formais (enquadramento, distribuição dos planos, iluminação, etc). Tudo isso ocorreu exatamente no mesmo momento em que se formava o Photo-Club do Rio de Janeiro e eram organizadas as primeiras exposições daqueles fotógrafos amadores. De alguma forma, o espaço que ali se constituía foi também de extrema importância para a produção de Sampaio.

Como já foi apontado em diversos estudos que tratam do problema da estética "pictorialista", havia nesses circuitos de amadores discussões bastante refinadas proveniente do campo das artes, que começam a criticar obras que seriam meras "cópias da realidade". Como vimos, os elementos principais da disputa eram apresentados como premissas consideradas quase universais para esse modelo de fotógrafo amador: a interpretação e o ponto de vista.

Certamente, devemos entender que em qualquer imagem há interpretação “interpretation [...] exists in all symbolic behavior", nos lembra Richard Chalfen (1987: 135, grifo original). Porém, nesse caso, a interpretação era transformada em vetor, mobilizada de forma consciente pelos fotógrafos. O ponto de vista seria uma das formas de atender a necessidade de interpretar, com o deslocamento no espaço para encontrar o 
"ponto justo", aquele que permitiria fugir das convenções e imagens que já compunham um determinado estereótipo. Quando Alberto de Sampaio deixa de realizar as fotografias tiradas em alto de morros, que dialogavam com a extensa produção dos profissionais, atuantes em Petrópolis desde os primeiros tempos da fundação da cidade, está se vinculando a essa percepção e se dispondo a encontrar outros elementos dessa mesma natureza. Seria aquilo que Eunapio Deiró muito bem traduz do artigo francês na revista Kosmos:

"[...] que assumptos admiraveis em humilíssimas cousas, que nos rodeam - si o coração e os olhos sabem descobril-as?! Uma estrada curva, uma barreira recta, um tecto fumegante, um tronco retorcido, uma hastea inclinada, um charco sob cuja superfície o céo estrellado reflecte-se tremulo, com suas nuvens, resteas de luz e de sombras...todos esses nadas ás vezes, inspiram os pintores e lhes geram n’alma admiráveis creaçoes esthéticas...” (11/ 1904, anno I, n. 11).

Ao final esse fotógrafo saberia descobrir os lugares especiais nas coisas comuns, porque dominava os recursos e métodos necessários para a apreciação da natureza. Mas Sampaio havia sido treinado não somente no campo fotográfico. Suas primeiras atividades, como apresentamos, começaram com o desenho e pintura de paisagens. Uma das aquarelas (Fig. 32) que Alberto de Sampaio produziu traz o texto: "Corrigido por Benno Treidler" (o artista que foi seu professor), imagem que mantém vínculo direto com a série de fotografias que privilegiam a vegetação. Na pintura o espaço está totalmente fechado: sem nenhum trecho do céu, apenas ressalta-se o rio que, subordinado à vegetação, serve apenas como reflexo para a mata densa das suas margens. Esse é o ambiente da total imersão no contexto e, certamente, a imagem foi produzida a partir do contato direto com a natureza, como estava em voga nas escolas de artes. 
É preciso considerar que o problema da interpretação, amplamente referenciado pelos amadores, constituía o eixo central da crítica de arte nesses primeiros anos do século XX. Gonzaga-Duque Estrada seria um de seus mais veementes defensores, baseando-se em autores como Eugène de Véron que, em seu livro L'Esthétique (1878), desloca o problema da obra e o resultado final, para o artista. Confere assim importância ao produtor que decodifica o mundo visível de forma subjetiva. A idéia de cópia da natureza ou reprodução coloca-se num plano totalmente secundário. Por isso, como destaca Tadeu Chiarelli (1995: 35), o que Duque Estrada extrai de Véron seria essa preocupação em "enfatizar a liberdade individual do artista e sua originalidade".

As revistas ilustradas como Kosmos, Renascença e mesmo jornais como O Paiz traziam sempre textos a respeito das exposições que podiam ocorrer nesse momento, tanto no âmbito da Academia como em galerias particulares. Essas questões teriam então alcance mais amplo, uma vez que os críticos de arte disseminavam tal "vocabulário" nas publicações. Mas haveria aqui um problema central que constituiria a maior diferença no alcance e significado do problema da interpretação no campo artístico e fotográfico. Enquanto os pintores - e principalmente seus críticos - estavam preocupados na adoção do que seria necessário reter dessas teorias estéticas estrangeiras para o debate sobre a arte nacional (a qual se dedicasse aos temas e à representação da luz tão particular ao nosso país) a fotografia amadora, que seguia os cânones dos clubes de elite, se manteria totalmente à parte dessas discussões.

O descompromisso dos fotógrafos com qualquer preocupação em estabelecer aqui um contraponto ao que era produzido no Exterior fica evidente nos textos por eles publicados. Na Kosmos, como já destacamos, Deiró apenas comenta e traduz trechos de um artigo extraído de alguma revista francesa e, na Renascença, todas as referências são feitas diretamente ao Photo-Club de Paris. Eram divulgadas exposições, novos 
equipamentos e, acima de tudo, questões associadas ao debate estético, como se não houvesse diferenças a serem consideradas na apropriação dessas idéias e modelos. Ficavam de fora discussões básicas, importantes para os fotógrafos do período, como a necessidade de fazer adaptações para medição da luz (como destacamos, as tabelas que acompanhavam as câmeras e manuais estrangeiros eram formuladas para outras condições de iluminação, de países situados no hemisfério norte). E quando faziam referência ao uso da luz, os artigos apenas ressaltavam sua relevância, para a forma particular de o amador realizar uma obra pessoal. Vale lembrar que parte da atividade clubística amadora, de maneira geral, vinculava suas proposições, exclusivamente, ao problema estético. Não haveria diferença, portanto, no caso brasileiro.

Tais questões estarão presentes na produção de Alberto de Sampaio, como na série de nove imagens tiradas num mesmo bosque em Cambuquira, em 1908. Quase todas elas apresentam contrastes intensos e, de fato, isso só poderia ser realizado com muita experiência, porque apontar a câmera de frente para o sol exigia a utilização de filtros de compensação, controle do tempo e da velocidade de exposição dos negativos, enfim, recursos técnicos para que a cena não ficasse com contrastes exagerados.

Nessa época, em que Sampaio já contava com cerca de vinte anos de dedicação à prática fotográfica, o sol praticamente ocupa papel central. Algumas das imagens são diretamente referenciadas como "Árvore contra o sol" e "Por do sol em Cambuquira". Mas a atenção seria maior nas gradações de iluminação como aparece em "Interior da matta" (Fig. 33) e demais tomadas realizadas nesse mesmo bosque. Aqui Sampaio utilizou filtro e lentes especiais para conferir o efeito flou, um pouco fora de foco, que torna a iluminação mais suave. Essa técnica foi muito divulgada no período e, por isso, Deiró assim se refere à questão no artigo da Kosmos: 
“O flou [...] é o equivalente n'arte, duma das cousas amadas da vida: esta deliciosa incerteza d'uma alma, onde já penetrou a esperança [...] onde advinhase e não se confessa [...] onde as figuras e paysagens, o céo e a terra - até o próprio amor - aparecem ao impulso de incertas suggestões da alvorada e não sobre a torrida, enfadonha e fatigante definição dos meios dias" (11/ 1904, anno I, n. 11).

O problema da nitidez, que era criticado dentro desses circuitos, baseava-se, como vimos, em componentes fisiológicos - teorias sobre a visão - e pesquisas sobre equipamentos. Mas nesse trecho aparecia como uma alusão poética que, de fato, traduz o que se procurava alcançar com esses efeitos luminosos: apenas um deleite pessoal proporcionado pela realização da fotografia. Alberto de Sampaio adere ao debate e forma de apreciação da natureza, conforme fica explicitado na fotografia "WestphaliaPetrópolis" (Fig. 34; 34. 1) que ele publicou na Renascença, na edição de maio de 1907 (anno IV, n. 39). É um caso exemplar e de exceção, pois o registro saiu do ambiente doméstico e está na principal revista para o Photo-Club do Rio de Janeiro.

A fotografia ocupa a página inteira, como era comum neste periódico, nas tais reproduções artísticas, que traziam registros de paisagem de fotógrafos amadores (a maioria de Alfredo Ferreira Laje) e profissionais como Marc Ferrez e Jorge Henrique Papf (que mais contribuiu, com 10 fotografias de Petrópolis, entre os anos 1906-07). Na maior parte das vezes, havia crédito ao autor, mas em poucas situações só era referido o título. Foi o que aconteceu com Alberto de Sampaio. Poderíamos até pensar que a tomada seja de Papf, porque se assemelha aos registros de Petrópolis desse profissional, ali publicados. Mas temos o negativo original, a cópia da fotografia em vários álbuns e nos volumes de catalogação elaborados por Sampaio, o que nos permite comprovar sua autoria.

A cena está vinculada à série dos rios. $\mathrm{O}$ formato é também vertical, tendo uma árvore como tema. Apesar de o espaço ser fechado, limitado pelo morro, é também 
amplo, e ressalta três elementos principais que integram a topografia do vale: terra, água e vegetação. O mais interessante, no entanto, é que os elementos singulares estão unificados, homogêneos, pela ação da luz que é capaz de fazer com que a natureza se integre visualmente. Sampaio usou aqui a lição de que a fotografia é captação luminosa, aplicando-a na paisagem. O problema do ponto de vista e da imagem com pouca nitidez, da estética "naturalista", evidencia-se fortemente nesse tratamento de uma cena comum, com objetivos artísticos. O resultado é a integração dos planos, e a natureza aparece não como um somatório de componentes, mas como espaço de articulação.

O mesmo problema será altamente demarcado num outro registro (Fig. 35), que ficou restrito ao acervo do fotógrafo. Trata-se de uma fotografia de um bosque, em que Sampaio escreve, diretamente no suporte em vidro, um poema por ele escrito entre 1892-96, denominado "Paysagem". Ele utiliza a mesma caneta empregada para os registros técnicos, só que agora, escreve um longo texto que se sobrepõe à imagem. Não é a única poesia com esse título (há mais três no caderno denominado de "Rimas por Alpha”), porém, foi somente nesse caso que encontramos associação com a fotografia.

O formato da tomada é horizontal, permitindo assim ressaltar ainda mais os elementos encontrados na série. Aqui, há total imersão no espaço, sem nenhuma hierarquia dos componentes: a base é composta pelo rio; nas laterais, a vegetação é tão abundante que não permite distinção das espécies; e, ao fundo, está a ponte que atravessa o rio, único elemento de intervenção humana no espaço. Na imagem tudo está integrado, articulado e a fusão acentuada, possibilita a própria escrita do texto na parte mais densa com vegetação. No poema, as questões serão semelhantes:

"Paysagem

No bosque, é tudo sombra fresca e muda... Aqui, um tronco podre esfacelando dá fresco, força, seiva a um irizado 
pé de begônia, que vigor eschuda

Alem, é um coqueiro agigantado

Que abre no ar, a folha-que não muda

Quando a borrasca, doida, atroz, sonâmbula...

Sacode-a, n’um vae-vem desenfreado...

Alli, um galho enorme e retorcido

Como si um braço fora gigantesco

Suporta um grande gravatá florido,

E, sob a cúpula escura do arvoredo,

Tendo por leito pedras escavadas

Vê-se o regato deslizando ledo..."

Os termos como “aqui” e "ali” são indicativos de que há seleção e, ressalta-se, que o lugar é cômodo, muito agradável, da "sombra fresca". Mesmo quando há "borrasca", vento forte acompanhado de chuva, a estabilidade permanece entre os diferentes elementos que lá estão, e nada se altera. Desta maneira, tronco, coqueiro, galho, gravatá, pedras e rio estão numa total simbiose e equilíbrio. Na gradação, vê-se a importância da vegetação, que cobre até o espaço do céu, formando uma "cúpula escura”, o que acentua o sentido de fusão. Há também aqui reciclagem, fundamental para a manutenção dessa estabilidade.

Portanto, nesse uso inusitado da fotografia com o texto, notamos mais um avez que a natureza para Sampaio era algo acolhedor, de espaços pequenos e de imersão, altamente relevante para a produção que se filiava ao debate estético proferido no momento. Nesse exercício, descompromissado, para apenas atender ao gosto pessoal, evidencia-se também as diferenças entre os pintores de paisagem e os fotógrafos amadores. Como vimos, ambos compartilhavam de conceitos e modelos externos semelhantes, mas os "efeitos" seriam totalmente diversos. 


\section{O Campo/a roça}

A maior parte das fotografias dessa série foi realizada em fazendas de familiares de Alberto de Sampaio, situadas na região do Vale do Paraíba. Em número muito menor temos cenas no Rio de Janeiro (pescadores na praia), Cambuquira, Petrópolis e na viagem à Europa. Há também aqui diferenças entre as imagens do século XIX e início do XX. No começo da atividade de Sampaio a representação do campo era escassa e, na maior parte das vezes, relacionada com os equipamentos que ressaltavam o espaço de produção. A partir de 1905, as imagens se diversificam: encontramos cenas que dialogam com o cânone estético do Photo-Club e outras que apenas registram atividades dentro da propriedade - exercidas pelos membros da família de forma descompromissada ou com trabalhadores e animais.

A fazenda Santa Alda, situada no município de Além Paraíba (MG), onde se concentra grande parte dos registros, pertencia a João Teixeira Soares (sogro de Alberto de Sampaio). Chacrinha, Vista Alegre e Campo Alegre, que ficavam em Valença (MG), eram propriedades de Horácio e Álvaro Mendes de Oliveira Castro, irmãos do já referido Otávio de Oliveira Castro, também fotógrafo amador. Eram antigas fazendas que no século XIX foram grandes produtoras de café, no período áureo do Vale do Paraíba.

Mas no momento em que Sampaio começou a freqüentar essas fazendas, elas estavam associadas também a outras atividades, como em Chacrinha, que tinha uma fábrica de polvilho. As plantações de café ainda permaneciam, porém, como já foi muito ressaltado pela historiografia, não era mais possível obter lucros extensivos naquela região. As terras haviam sido esgotadas durante décadas de uso agressivo do território e das fontes naturais. 
De todas essas fazendas era em Santa Alda que havia a produção mais significativa de café. Os interesses de João Teixeira Soares, no entanto, eram outros, muito mais direcionados à obtenção de melhorias na produção e, por isso, investia também em pesquisas. O café de Santa Alda alcançaria reconhecimento internacional, conforme indicam as premiações recebidas pela fazenda na Exposição Nacional de 1908, na Exposição de Bruxelas em 1910, dentre outras. A qualidade do café era reconhecida até por aqueles que estiveram na fazenda como Georges Clemenceau, que publica em 1911 matérias na revista L'Illustration e no jornal The New York Times descrevendo sua visita, naquele ano, ao Brasil. Dentre os locais visitados, era em Santa Alda que se produzia, segundo ele, o melhor café do país, até porque essa plantação não tinha fins econômicos.

As fotografias irão representar certos aspectos das relações de ordem familiar estabelecidas com essas regiões e, em algumas situações, o modelo estético difundido entre os amadores no Photo-Club do Rio de Janeiro. As primeiras imagens nas fazendas foram realizadas no século XIX e, da mesma forma que as demais séries analisadas, houve pouca produção nesse período, apenas nove fotografias. Nesse conjunto, Sampaio privilegiou a representação da relação maquinário/homem/animal como em “Despolpador em Santa Alda" de 1895 (Fig. 36), que registra um grupo de crianças em frente ao carro de bois, cuja função era descarregar o produto no equipamento situado abaixo do telhado, que descascava o café. Apesar do equipamento ser referido no título, ele ocupa papel secundário, pois o destaque é dado às crianças e bois.

A partir de 1905 são produzidas diversas séries, num total de 67 fotografias; algumas delas continuam a valorizar os equipamentos, porém, nesse momento, Sampaio utilizava as condições de iluminação e composição de forma diversa. Isso porque suas preocupações estéticas, oriundas do debate dos clubes, conforme já apresentamos, irão 
se acentuar também na representação do campo. "Carro de cabritos em Santa Alda" de 1905 (Fig. 37) é representativo desse olhar que se apropria de espaços fechados, tornando-os acolhedores através dos efeitos de variação da luz sobre as folhagens e da disposição dos planos. Nota-se que, na imagem, há uma criança e o próprio carro é pequeno, parece quase uma miniatura, o que acentua essa percepção de que a natureza não era algo intransponível a ser domado, mas que, antes de mais nada, estava próxima à escala do homem e incluía aspectos lúdicos.

Situação semelhante pode ser observada nos registros de trabalhadores em Cambuquira, no Rio de Janeiro (na praia) e na Europa. Mas é nas fazendas que se concentra a maior parte da produção e algumas dessas fotografias foram reproduzidas diversas vezes com diferentes técnicas, ressaltando o valor que o próprio Sampaio conferia a elas como a imagem, sem data, que documenta dois homens descascando milho (Fig. 38). Aqui Sampaio também explorou as variações de iluminação - a câmera está direcionada para o sol - e, no negativo, ele valoriza o espaço que compõe o entorno, diferentemente das edições posteriores como uma cópia em platinotipia (Fig. 38.1). Esta imagem editada tem como foco de atenção a atividade: temos a ação (o trabalho que está sendo desenvolvido) e os tijolos como elementos disponíveis que são agenciados. Não há, portanto, nenhuma intermediação pelo equipamento e o homem é visto como um ser integrado à natureza.

Desprezava-se assim qualquer vínculo com a esfera produtiva da sociedade, da parte economicamente ativa cujos atributos de modernização eram simbolizados pela introdução do maquinário. A representação simbólica dos modos de vida da população mais "simples" do campo era um indicativo de uma apreciação qualificada, elemento de distinção social de homens cultivados, de "fino gosto". 
Mas havia muitos registros das atividades ocorridas nas fazendas que escapam a essas implicações de ordem social legitimadas pelo discurso estético. O objetivo, nesse caso, é apenas documentar, embora sejam utilizados elementos gerais apreendidos nos debates do Photo-Club, como "Curando bezerros em Sta. Alda" de 1905 (Fig. 39). Aqui temos uma fotografia ocasional dos animais dentro da propriedade, recebendo o tratamento que o lugar impunha.

Seguindo a mesma problemática das tomadas ocasionais, há cenas de membros da família desempenhando alguma atividade - sempre de lazer - a cavalo, se preparando para um passeio, segurando alguma arma de caça ou fazendo ginástica como em "Gymnastica no pic-nic" de 1911, realizada na fazenda Chacrinha (Fig. 40). As atividades desempenhadas no campo são objetos de atenção, atendendo à função de memória do evento que merece ser documentado pela sua diferença e tipicidade, algo que não ocorria na cidade.

É preciso destacar que, nesse momento, as fazendas não eram mais unidades de produção, espaços cujos laços familiares se mesclavam com as relações de poder como bem demonstrou Mariana Muaze ${ }^{68}$ (2008) em sua análise sobre membros da "classe senhorial oitocentista" no Vale do Paraíba. A situação havia mudado. Muitas dessas fazendas haviam sido transformadas em áreas de visita esporádica e podiam, agora, ser espaço de recepção ou lugar de passatempo familiar. Em tal contexto, as interações sociais serão também de outra ordem, reveladas pelo descompromisso com que as pessoas passavam a ser registradas. O campo representado como lugar de veraneio e

\footnotetext{
${ }^{68}$ De acordo com Muaze (2008: 190), no estudo sobre a família Ribeiro Avellar, que era dona da fazenda de Pau Grande, situada em Vassouras (RJ), existia um núcleo de residências que serviam à família. Além da sede da fazenda, as casas, na corte e em Petrópolis, permitam a manutenção de prestígio, renovação de contatos sociais e materiais, etc. Porém, tais grupos tiveram sua origem e lugar na sociedade estabelecidos pela riqueza produzida naquelas terras, o que delinearia suas relações políticas, econômicas e familiares.
} 
diversão aparece também nas cartas escritas por Cecília Sampaio, numa ocasião em que ela e alguns filhos estiveram na fazenda Chacrinha, por volta de $1912{ }^{69}$ :

"Hoje de manhã fui com papae e Dalila fazer um passeio a Cavallo pela Santa Cecília, e fizemos uma porção de voltas, passamos por uma linda matta. Dalila e eu apreciando a calma e grandeza da roça. Dizíamos que nem um footing no Flamengo é melhor que um passeio d'estes" ( 2 de junho).

Cecília associa o passeio ao deslocamento, mas a roça tem uma natureza específica, e ela aprecia a "calma" e "grandeza", um atributo desse espaço, porque tem sentido mais amplo e engloba a mata. Na cidade do Rio de Janeiro, apesar de ter condições especiais na natureza, a mediação tinha conotações de caráter social. Ali era o espaço do "footing", que integrava o roteiro das famílias de elite e seus passeios semanais no bairro do Flamengo. O campo era propício à introspecção, também lugar privilegiado para apreciar a beleza que não era aqui um a priori, uma essência, mas circunstancial. Era preciso estar atento então para o que merecia ser fotografado:

“[...] A tarde estava linda e senti muito não ter levado uma camara pois seria uma fotografia muito bonita - com um sol, um grande pasto cheio de vacas, com um rancho grande - estava poético. [...]" (1 de julho).

Mas essas fazendas, agora servindo de estadia temporária, haviam sido grandes centros de produção de café e contavam com instalações modernas. Ainda no século XIX foi construída uma linha de bondes que ligava as diversas fazendas que ainda eram de propriedade de Manoel Pereira de Souza Barros, o Barão de Vista Alegre. Ele instalou nada menos do que sete quilômetros de linhas de bonde puxados a burro, que

\footnotetext{
${ }^{69}$ Cecília escreve diariamente, relatando o que havia acontecido. Como não temos os envelopes das cartas não foi possível identificar o ano. Mas pelas referências aos eventos ocorridos, supomos que a estadia na fazenda tenha ocorrido em 1911. Temos, no entanto, os dias registrados em cada carta.
} 
interligavam suas propriedades à Estação de Souza Barros. ${ }^{70}$ De alguma forma, a cidade invadia o campo, sendo representada fortemente pelos meios de transporte empregados. Essas características peculiares chegaram aos dias de Alberto de Sampaio, como ocorre na única fotografia "Bonde em Chacrinha" de 1911 (Fig. 41). Obviamente, ainda servia de transporte de pessoas e de materiais da fazenda, mas também podia ter outra função, como notamos na descrição de Cecília:

"Hontem a noite fomos fazer o nosso passeio com o luar; mas o Bond tem tolda e isto não deixa apreciar bem o luar. [...]. Com a história do luar sonhei que estávamos no Rio e que eu tinha preparado um passeio para hoje no Pão de Açúcar!” (21 de julho).

O bonde havia-se convertido aqui em veículo de desfrute da natureza e, por meio do luar, Cecília faz a transferência da roça para a cidade. Havia de novo mediação entre campo/cidade, mencionada diversas vezes em cartas de Cecília, porém tal oposição não ressalta aspectos pejorativos. Aqui não ocorreria um olhar crítico sobre o campo. Na visão de Cecília e Alberto de Sampaio a conotação seria diferente: para eles o luar, a mata, enfim, a natureza do campo tinham valor positivo.

Tal conversão das fazendas a espaço de veraneio e referência da manutenção de certo status - de forma totalmente diversa do significado social e político alcançado pelas propriedades no século XIX - fica explicitada também na série de vistas panorâmicas realizadas por Sampaio. Foi ali que o fotógrafo se dedicou à realização dessas tomadas em chapas de grande formato, que, justapostas, permitiam visão ampla

\footnotetext{
${ }^{70}$ Segundo Adriano Novaes (2009: 112), as fazendas pertenciam a Manoel Pereira de Souza Barros, o Barão de Vista Alegre, que herdou as terras de seu pai, grandes produtoras de café no século XIX. A sede principal, originalmente, ficava em Vista Alegre. A luxuosa residência "Solar da Chacrinha" tem sua construção iniciada somente em fins da década de 1860 e conclusão, em 1881. Esse conjunto de propriedades, mais a fazenda de Santa Thereza, foram adquiridos pelos irmãos Oliveira Castro em 1901. Eles formaram a Companhia Alliança Agrícola, tendo ainda as fazendas de Caieira e Sítio do Retiro (Velho). O autor relata ainda que o Barão de Vista Alegre também instalou linhas telefônicas, um gasômetro e uma escola para "ingênuos", onde eram alfabetizados os filhos de escravos e crianças pobres da região. Disponível em: http://www.institutocidadeviva.org.br/inventarios/sistema/wpcontent/uploads/2009/11/25 adriano-novaes.pdf.
} 
do espaço. Há pelo menos quatro dessas vistas, sendo que três delas foram feitas, cada uma, com quatro negativos de vidro de 12 x $16 \mathrm{~cm}$, nas fazendas de Vista Alegre, Chacrinha e Campo Alegre. Sampaio, com essas imagens, demonstra todo o domínio técnico adquirido nesses longos anos de atividade e, além disso, que também estava atento a um gênero já reconhecido no universo dos profissionais - ele inclui até mesmo uma figura humana para dar escala à cena, conforme ocorria nas imagens que circulavam no período.

Esse modo de registrar a paisagem nacional tinha entre nós muitos representantes. O mais célebre e reconhecido seria Marc Ferrez que, segundo Maria Inez Turazzi (2005: 16), demonstra em sua "vontade panorâmica" certo encantamento pela paisagem nacional. Mas havia também, dentre esses profissionais que se especializariam em vistas panorâmicas, Jorge Henrique Papf, como já destacamos.

É preciso ressaltar que, além das relações com o campo fotográfico, as tomadas tiradas em alto de morros nas fazendas eram representativas de determinada pintura de paisagem realizada por artistas como Georg Grimm, Nicolau Fachinetti e mesmo Antonio Parreiras. Segundo Rafael de Bivar Marquese (2006: 68-76), essas pinturas alcançaram seu ápice na década de 1880, período de declínio da produção de café nas regiões do Vale do Paraíba, num quadro de crise da escravidão. Segundo o autor, esse tipo de pintura foi, de certa maneira, "ativada" no momento de decadência econômica da região, circunstância evidenciada em algumas dessas imagens que traziam marcas de uma natureza em desequilíbrio com voçorocas, grandes áreas sem plantio, etc. E, ainda, pelo próprio fato de que as encomendas eram feitas por fazendeiros, filhos dos primeiros proprietários, uma segunda geração que herdava as terras exauridas e começava a enfrentar grandes baixas de produção. Grupo que tinha interesses expressos em demarcar visualmente o patrimônio herdado, que se via ameaçado. 
Nesse contexto, houve também a introdução da fotografia ${ }^{71}$. Na década de 1880 fotógrafos como Marc Ferrez seriam contratados diretamente pelos proprietários ${ }^{72}$. Mas é preciso considerar que essa produção foi restrita, pois como Ana Maria Mauad (2001: 222) salientou, são raros os álbuns das famílias dessas regiões que contêm registros das próprias fazendas.

Dentro dessa produção, há fotografias da própria fazenda de Campo Alegre, realizadas por Marc Ferrez. Ali ele fez vistas panorâmicas como a imagem tirada do alto do morro que coloca em evidência o terreiro para secagem do café (Fig. 42). Observamos que grande parte da área estava coberta pelos grãos, o que significava ainda significativa produção nessa propriedade. Quando Alberto de Sampaio registra a mesma fazenda entre os anos 1900-10, a situação já era bem diferente (Fig. 43). Na sua vista panorâmica - tomada do mesmo lugar que a foto de Ferrez - o terreiro estava praticamente vazio e por isso esse espaço se destaca. Percebemos que os morros, mesmo mais distantes, não tinham nenhuma plantação de café, praticamente todos estavam cobertos pela vegetação. Aliás, nota-se preocupação estética na ordenação das grandes palmeiras que ficam no entorno do terreiro, que possivelmente já haviam sido plantadas no século XIX, como é possível perceber nas imagens de Ferrez. Entretanto, os efeitos paisagísticos de fato só ocorreriam na época em que Sampaio as fotografou.

A conversão dessas fazendas em lugares também de veraneio do grupo familiar implicava diretamente nessas mudanças de função dos espaços, principalmente o terreiro de café: anteriormente era direcionado ao trabalho, à produção, depois começam a ser transformados em jardins. É possível perceber as mudanças nas próprias panorâmicas realizadas por Alberto de Sampaio, como na fazenda da Chacrinha que foi

\footnotetext{
${ }^{71}$ As primeiras fotografias de fazendas já foram realizadas por Victor Frond na década de 1850. Mas aqui era um projeto pessoal, que apesar de se vincular aos desejos de representação das elites locais, nutriam diferentes objetivos, como demonstra Lígia Segala (1998).

${ }^{72}$ Novaes (2009) apresenta algumas imagens de fazendas no Vale do Paraíba que foram documentadas por Marc Ferrez na década de 1890.
} 
fotografada em dois momentos: a primeira imagem foi realizada em grande formato, faz parte do conjunto citado acima, posteriormente temos uma segunda vista com negativos menores, de 10 x 8,5 cm. A fotografia (Fig. 44), mais antiga, integra a mesma série da fazenda Campo Alegre e talvez tenha sido realizada nos primeiros anos após a compra das terras pelos irmãos Horácio e Álvaro Mendes de Oliveira Castro, pois vemos ainda poucos morros com plantação de café. $O$ terreiro situado em frente à residência principal também está vazio. Á esquerda há um trecho em terra batida e outro coberto por pequena vegetação. A segunda fotografia é, certamente, posterior a década de 1910 (Fig. 45). Nota-se aqui outro tipo de vegetação, já com objetivos estéticos, circundando a residência principal. Partes do terreiro havia-se convertido num jardim: há trechos gramados, pequenos arbustos e uma entrada em curva que, mesmo sem ter sinais de planejamento, nos remete para algum tipo de atenção diferenciada para o espaço.

Logicamente, nas fazendas havia atividades com objetivos econômicos, seja na produção de café ou com a fábrica. Mas as relações entre os donos da terra e o espaço eram outras. Apesar de os proprietários descenderem do Barão de Oliveira Castro, um antigo grande fazendeiro da região de Valença, eles não mantinham ali o núcleo central familiar, como havia ocorrido durante todo o século XIX. A própria forma como tinham adquirido as propriedades, num leilão realizado pelo Banco do Brasil em 1901, é indicativa dessa diferente relação que seria estabelecida com a região.

De fato, as fazendas serviam como um segundo negócio, pois eles tinham outras atividades na cidade do Rio de Janeiro e Petrópolis. Isso ficava mais evidente no caso de João Teixeira Soares que era um empreendedor, que participou de grande parte da construção de estradas de ferro daquele período. As fazendas podiam servir, nesse caso, muito mais como meio de articulação, sendo espaços diferenciados para recepção social. Era para lá que ele levava pessoas como o então Presidente da República 
Marechal Hermes da Fonseca, Paulo de Frontin, Epitácio Pessoa ou Carlos Sampaio, que seria mais tarde prefeito do Rio de Janeiro, ou mesmo o chanceler francês George Clemenceau na sua visita ao Brasil ${ }^{73}$. As fazendas se transformavam, assim, em lugar de manutenção de um determinado status e de ligação simbólica com a ainda fonte de riquezas para o país, o café, que gerava suas fortunas em outra região, agora em São Paulo.

No entanto, as fotografias de Sampaio em formato panorâmico, que ressaltam a propriedade e o espaço de amplo alcance, não foram valorizadas pelo próprio fotógrafo. Elas não constam no caderno de anotações e por isso não têm título como as diversas outras cenas citadas anteriormente. De alguma forma "O carro de cabritos em Sta. Alda" (Fig. 37) expressava valores que escapavam às vistas panorâmicas. Aí entramos no âmbito das discussões estéticas, que tinham os termos "interpretação" e "ponto de vista" quase como palavras de ordem. Obviamente essas questões estão presentes em todas as fotografias, inclusive em qualquer tomada panorâmica. É preciso sempre escolher o local, selecionar o que merece ser registrado e situar-se, portanto, num ponto especial. Mas não era assim que os amadores compreendiam e validavam esse tipo de imagem. O mesmo artigo de Enapio Deiró, a que nos referimos anteriormente, assim destaca a questão:

“[...] o photographo quer reunir a maior quantidade de cousas possíveis, no espaço do aparelho, além de ver simultaneamente o que lhe roja aos pés e o que eleva-se acima da linha do horizonte. Porque em seu desejo de abranger grande soma de minucias e, em sua profunda ignorancia da lei dos sacrifícios necessários, quer alcançar com os olhos o objectivo, já que não o pode fazer com um só olhar. E' assim que nas provas, cuja perspectiva nos incomoda, a photographia vê-se coagida a registrar muitos planos, que não receba no seu

\footnotetext{
${ }^{73}$ Encontramos notícias dessas visitas no jornal Tribuna de Petrópolis, que trazia em alguns dos pequenos informes sobre a vida social da cidade, notícias de pessoas que João Teixeira Soares levava para sua residência, em Petrópolis, ou para a fazenda Santa Alta. A menção à Clemenceau aparece em 10 de outubro de 1910. Houve também uma única viagem em que integraram Marechal Hermes da Fonseca, Paulo de Frontin, Epitácio Pessoa, Carlos Sampaio e Alberto de Sampaio, em 7 de abril de 1910.
} 
complexo e que nunca teria reunido em sua imagem, não os reunindo na nudez da realidade.

Ahi está o defeito; não vem da objectiva; procede pelo contrário, de haver mais subjectivo no operador; resulta do seu falso sentimento de bello" (11/1904, anno I, n. 11).

O que seria considerado como o "bello" se oporia às imagens que demarcavam diversos e amplos planos, porque assim se percebia algo que escapava ao olhar humano. O problema da fisiologia da visão fica embutido nessa discussão, a qual coloca em desvantagem, de forma mais contundente, as fotografias em formato panorâmico, comumente realizadas do período, apreciadas em exposições e cartões postais. Assim, a tão propagada expressão da individualidade representava sobretudo a valorização de imagens de imersão, de proximidade à cena e de um determinado pertencimento ao espaço, que escaparam aos profissionais de gerações anteriores como Georges Leuzinger, mas que estavam também presentes, de formas diversas, naqueles que vivenciaram a passagem do século XIX para o XX e que estabeleceram algum diálogo com o que se discutia nos clubes de amadores como Marc Ferrez, Jorge Henrique Papf ou mesmo Augusto Malta.

Por isso, Sampaio revela, no uso descompromissado da fotografia, as diversas orientações do campo dos profissionais ou dos amadores. A própria variação de importância que ele confere à sua produção (no processo de seleção das imagens que mereciam ser incluídas na catalogação) evidencia as relações estabelecidas com elementos da cultura amadora do período. No caso das fazendas, apesar de ser conferida maior relevância às cenas que se chamavam na época, em revistas ilustradas, estrangeiras de "paysage animé"74 (que tinha sempre um personagem do lugar sendo documentado em meio à natureza), ele realiza vistas panorâmicas, nos mostrando as transformações do uso do espaço nesses locais, nos primeiros anos do século XX.

\footnotetext{
${ }^{74} \mathrm{Na}$ Lectures pour tous encontramos, algumas vezes, esse termo nas matérias sobre as exposições e concursos (10/1900: 348, 3me année, n.1).
} 
As regiões que haviam sido emblemas do Império e de suas contradições, fonte da riqueza gerada pelo café, lugar da destruição da natureza e do emprego da mão de obra escrava em larga escala se converteram em lugar que, economicamente, representava um segundo negócio para as famílias que viviam em centros urbanos. Por isso, eram percebidas como a "roça", espaços que se opunham às cidades. Nesse contexto, se alteravam as relações ali estabelecidas e, por conseguinte, a forma com que as pessoas se deixariam ser fotografadas.

\section{Paisagem industrial}

Essa série trata do registro da natureza modificada por empreendimentos e construções, a maioria ligada às estradas de ferro, mas ainda mantendo sua força. Há poucas imagens do século XIX, sendo a maioria cópias em papel com qualidade bastante inferior, que estão num álbum denominado por Sampaio de "Destruídas". A partir de 1905 temos maior produção de fotografias, as quais também se diversificam: há cenas de obras, estações e linhas de trem.

De forma geral, Alberto de Sampaio não demonstra haver nessa série nenhum trabalho de documentação, organizado previamente para esse fim. Os registros são esporádicos, muitos espaçados no tempo, e se detêm naquilo que lhe chama mais atenção. Por isso, existem lacunas consideráveis. Afinal, ele morava em Petrópolis e não conhecemos fotografias nem mesmo da estação ferroviária por ele utilizada quase diariamente no centro da cidade. E nos poucos registros de estações de trem não há valorização da arquitetura ou contrastes estabelecidos com a natureza do entorno. Mas é preciso destacar algumas transformações ao longo do tempo.

No século XIX a única imagem que possui negativo (e de que podemos ter melhor visibilidade) é a da "Ponte das Garças" (Fig. 46), na estrada União e Indústria, 
inaugurada em 1861, empreendimento de Mariano Procópio Ferreira Laje. A conhecida estrada foi tomada por Alberto de Sampaio de forma totalmente "amadora". Aqui ele estava sentado à frente, talvez de uma diligência, que fazia o trajeto entre as duas cidades, Petrópolis-Juíz de Fora, e, por isso, há esse desnivelamento. Tentativa um tanto diferente, uma vez que ele estava usando uma câmera de grande formato, pesada e que certamente não poderia ser "aprumada" com o movimento. Mas seu objetivo era apenas acentuar a perspectiva da ponte metálica no momento que antecedia a entrada nesse espaço. Daí a importância dos cavalos no primeiro plano, certificando a presença do fotógrafo no meio de transporte.

Tudo muito diferente da fotografia realizada por Klumb e publicada em 1872 no livro Doze Horas em Diligência - Guia do Viajante de Petrópolis a Juiz de Fora (Fig. 47). Imagem que Sampaio conhecia, pois essa publicação fazia parte de seu acervo, certamente devido às relações diretas da sua família com os Ferreira Laje. Vale lembrar que Sampaio era neto de José Machado Coelho que, além de diretor da Estrada União e Indústria, tinha laços de parentesco muito estreitos com essa família de Juiz de Fora, conforme já ressaltamos. Mas a fotografia de Klumb, ao contrário do registro ocasional de Sampaio, é magistral em termos técnicos. A construção metálica aparece com sua geometria imponente, em contraste com a natureza aparentemente original. A imagem demonstra assim o desígnio e domínio do homem sobre o espaço, constituindo um claro exemplo de como os profissionais iriam registrar o encontro entre a natureza e o espaço construído no século XIX.

A documentação de obras públicas, notadamente de estradas de ferro, realizada pelos principais fotógrafos profissionais do período, tinha como função o registro técnico dos empreendimentos para compor o quadro das empresas e também a "formação de uma memória" de instituições que estavam envolvidas nesses projetos no 
período Imperial, como demonstrou Maria Inez Turazzi (2006: 66). Para a autora, o próprio fato de as imagens circularem em exposições nacionais e internacionais, sendo ali premiadas, indica de que forma a produção de fotografias de obras públicas vinha atender ao desejo de construção simbólica da nação ${ }^{75}$, segundo os desígnios do progresso e da modernidade.

Mas tais questões escapavam ao olhar de Sampaio. Em "Entre Rios" de 1895 (Fig. 48) a linha de trem aparece como elemento secundário, havendo valorização do conjunto de palmeiras situadas à parte esquerda na fotografia. Ele está interessado, nesse caso, nos efeitos visuais da linha de trem para apenas estabelecer um desenho, uma composição, num espaço amplo cujos sinais de urbanização eram precários.

No século XX temos mudanças importantes, pois há um maior número de imagens de estradas de ferro. É preciso considerar, a partir de então, o componente familiar e profissional nessa relação de Alberto de Sampaio com as obras ferroviárias. Seu sogro, João Teixeira Soares ${ }^{76}$, como ressaltamos, foi um dos maiores construtores de estradas de ferro de seu tempo e teve uma carreira notável. Trabalhou na empresa francesa no Brasil, "Société Anonyme de Travaux Dyle et Bacalan” em 1882, na construção da Estrada de Ferro Paranaguá a Curitiba, no Paraná, obra de grande vulto naquele tempo. Em 1884, foi um dos responsáveis pela construção da Estrada de Ferro Corcovado. Vale mencionar que em ambas as situações, Teixeira Soares atuou diretamente com o então engenheiro Pereira Passos. Além disso, esteve associado durante longo período à construção da Estrada de Ferro Victória a Minas, tendo sido presidente dessa companhia de 1901 até seu falecimento em 1927. Certamente, a

\footnotetext{
${ }^{75}$ É o que Vânia Carneiro de Carvalho (1998: 217), analisando as fotografias da natureza aqui realizadas, no século XIX, irá denominar como "imagens da produção", em que mesmo o "exótico" e "provinciano" será transformando em símbolo de progresso.

${ }^{76}$ Eduardo Soares de Sampaio publicou um depoimento sobre a vida e a obra de João Teixeira Soares. Disponível em: http://www.autores.com.br/200804174058/Relacionamento/Saudade/joao-teixeirasoares.html.
} 
trajetória profissional de Teixeira Soares foi muito relevante para os empreendimentos que ocorreram no Brasil daquele momento. Afinal, ele foi responsável pela construção de 10 mil quilômetros de linhas férreas, o que lhe garantiu grande prestígio, assim como inserção em diversas redes sociais. Foi condecorado por diversas ordens no período imperial, participou de sociedades nacionais e estrangeiras e teve, inclusive, uma estação ferroviária batizada em sua homenagem, a Estação Teixeira Soares, situada na Estrada de Ferro São Paulo-Rio Grande do $\mathrm{Sul}^{77}$.

Assim, as construções de estradas de ferro faziam parte do contexto social de Alberto de Sampaio e, ele mesmo, trabalhou, como vimos, na Estrada de Ferro Peçanha Araxá e Cia. Estrada de Ferro Victória a Minas. Apesar desse vínculo tão próximo, Sampaio não se dedicou extensivamente ao registro de linhas férreas, pois sua importância, dentro do total do acervo, não se deve a termos quantitativos, já que a série é pequena.

No conjunto, a maioria das imagens passa a valorizar muito mais os componentes estruturais, como a "Ponte do Travessão" (Fig. 49), na qual se acentua a linearidade da armação de ferro. Porém, quase não há destaque para o fundo composto pela natureza, diferentemente da imagem de Klumb mostrada anteriormente. De todo modo, apesar de Sampaio dialogar com suas referências, não se evidenciará o que diz Maria Inez Turazzi (2006:65) sobre as fotografias dos profissionais: “a notável fusão da paisagem construída pelo homem com uma natureza monumental que enfeita e singulariza a topografia do lugar".

Os amadores teriam concepção diversa e, principalmente, Alberto de Sampaio. Na imagem da ponte (sem data), por exemplo, há destaque para a obra em andamento, daí a realização do instantâneo (Fig. 50). É preciso ressaltar que na maior parte das

\footnotetext{
${ }^{77}$ Cf. O empreendedor Teixeira Soares, Prefeitura de União da Vitória e Superintendência da Rede Ferroviária Federal, s.d.
} 
fotografias de estradas de ferro do século XIX, registradas desde Benjamin Mullock a Marc Ferrez, os trabalhadores eram representados posando defronte à câmera. Só veremos o movimento, a ação, muitos anos depois, em apenas algumas imagens da série de Dana Merill, que documenta a construção da ferrovia Madeira-Mamoré. Assim, diferentemente dos profissionais, Alberto de Sampaio interessa-se aqui pelo evento e centra sua atenção na ponte e equipamentos, minimizando mais uma vez o fundo composto pela natureza. Isso se torna ainda mais evidente na cópia em papel (Fig. 50.1) cujo entorno foi eliminado, alterando-se o formato original da fotografia.

Outro aspecto presente em sua produção do século XX é a valorização do deslocamento no espaço. Num conjunto de imagens realizadas em 1909 na Estrada de Ouro Preto ele realiza as fotografias dentro do próprio vagão em movimento. No caso, Sampaio não se interessa pela vista da janela, conforme aparece em imagens na Europa, como vimos em outra série. O importante é demarcar a linha do trem em perspectiva, assim como a transformação da natureza como em "Corte na linha Estrada de Ouro Preto" (Fig. 51). O próprio título remete à intervenção na rocha, o corte, que permite aos trilhos seguirem. Mais uma vez, o entorno tem papel reduzido, como em "Túnel na linha de Ouro Preto" (Fig. 52), em que o fotógrafo recupera, de forma diversa, sua primeira imagem realizada na "Ponte das Garças" em 1896, destacando o momento que antecede à entrada nesse espaço. O túnel aqui funciona apenas como uma moldura visual que enquadra a paisagem.

Esse determinado uso do espaço, de registro do deslocamento congelado pela fotografia, difere completamente da tomada, possivelmente do mesmo local, realizada por Marc Ferrez por volta de 1880 (Fig. 53). Nesse caso, a escala é diferente e o entorno é valorizado. Então, a ponte que atravessa o rio, o morro em pedra perfurado pelo túnel - que está coberto pela vegetação nativa - junto ao trabalhador posando no plano 
intermediário do quadro, revelam os embates existentes entre a obra e a natureza transformada pelos avanços da engenharia.

Alberto de Sampaio, contudo, não se atém aos contrastes na serra ou efeitos escultóricos da paisagem provocados pela introdução das estruturas em ferro, como aparece em Ferrez. Ao contrário, ele explora as tomadas em perspectiva central tal como o "travelling" do cinema, uma experiência visual marcada em outro contexto de produção e circulação de imagens. Esse era o período inicial de difusão do cinema e o trem, como lembra Lynne Kirby (1997: 20), era o personagem principal de diversos filmes e exercia certa fascinação, uma vez que "many early filmmakers were inventors, men with vested interests in machines, technology, and progress”. Mas na Europa e principalmente nos EUA, o trem teria, como diz a autora, um papel ambíguo e mesmo controverso. Podia representar símbolo do progresso; meio de integração de regiões distantes (seja na criação de novos centros ou para fins de lazer e turismo); invasão de locais onde viviam populações nativas; destruição da paisagem; fonte de medo e insegurança. Nesse contexto, os primeiros filmes produzidos trariam marcas de tais ambigüidades.

É o que Tom Gunning (2006: 27-30) evidencia quando afirma que os "travels films" e "railways films", nesse momento, estavam totalmente interligados, e o trem se tornaria num símbolo não somente do avanço capitalista, mas de tudo o que isso significava: expansão colonialista, reafirmação do interesse pelo exótico e apropriação imaginária do espaço, da mesma ordem que o cartão postal e outros artefatos visuais extensamente mobilizados na virada do século XIX.

No Brasil, o impacto da locomotiva seria diferente e demoraria muitos anos para que efetivamente regiões distantes pudessem ser transpostas pelas linhas férreas e interligadas entre si. Diversos ramais permaneciam isolados e atendiam a grande 
demanda por transporte de café do interior para o litoral, não sendo utilizados de forma tão intensiva como meio para deslocamento de passageiros no século XIX. A situação de Petrópolis seria uma exceção, tendo sido provida pela primeira linha construída no país, ainda em 1854, pelo Barão de Mauá ${ }^{78}$. Como relata Pedro Vasquez (2007: 43), ali o trem cumpria a função evidente de servir como meio de transporte para uma elite, o Imperador e a corte, em seus períodos de veraneio na cidade, num quase deslocamento do centro político da capital do país para a serra.

Mas, entre nós, a ferrovia seria também uma metáfora "dos desvios" do progresso, conforme muito bem ressalta Francisco Foot Hardman (2005: 31), sobre a construção da Ferrovia Madeira-Mamoré. Ali, segundo o autor, nos primeiros registros produzidos pelo engenheiro e fotógrafo amador Carlos Morsing - que chefiou o início das obras ainda no século XIX - pode-se entrever uma natureza "bravia e indomável". Já na documentação, anos mais tarde, de Dana Merril, evidencia-se a natureza "produtiva”, com todos os desígnios e contrastes que isso significava.

Certamente, num contexto igualmente contraditório, mas totalmente diferenciado dos países produtores dos "filmes de viagem", aqueles que seriam exibidos aqui, explorando as locomotivas como personagens principais, teriam espaço de circulação e recepção muito distintos. Não podemos marcar tais trajetórias, há escassez de informações sobre o tema. Mesmo assim, é possível perceber nos registros de Sampaio uma forma dessa mediação. Com seu interesse já restrito pela demarcação de grandes contrastes, desde o início da produção fotográfica, teríamos, no século XX, o problema do deslocamento, validado pela "experiência" do movimento e do

\footnotetext{
${ }^{78} \mathrm{O}$ primeiro trecho inaugurado, em 1854 , da Estrada de Ferro Petrópolis, depois rebatizada como Estrada de Ferro Mauá, ligava o Porto Mauá até Raiz da Serra da Estrela. A parte inicial da viagem era feita por barca (que saía do porto do Rio e atravessava a Baía de Guanabara até chegar ao Porto Mauá). Depois havia o trajeto da Estrada de Ferro Mauá. Completava-se a viagem em carruagens ou diligências, que subiam a serra até chegar em Petrópolis. A situação se modificou em 1883, quando foi construída a Estrada de Ferro Príncipe Grão do Pará, que estenderia a ligação do trem da Raiz da Serra diretamente até o centro de Petrópolis (Gerodetti; Cornejo, 2005: 15).
} 
"travelling", como uma questão importante. Alberto de Sampaio se interessava pelas sensações provocadas pela linha atravessando as montanhas e túneis (à maneira de muitos filmes do período) em detrimento dos contrastes provocados pela relação espaço construído/cenário.

Integrando esta série, há ainda cinco fotografias realizadas em Ouro Preto, em 1909. São registros da exploração de ouro, em que aparecem trabalhadores e patrões. Possivelmente, foram produzidas no curto momento em que foi sócio na Cia. Mineira de Mineração e na transportadora de minério Lellis e Cia. Estas imagens, porém, se distanciam das próprias questões estéticas tão presentes nas fotografias de trabalhadores no campo, que mencionamos anteriormente. É uma série em que Alberto de Sampaio faz uso estritamente documental da fotografia, totalmente distanciado, por exemplo, do que seria o propósito e interesse etnográfico das excursões estabelecidas pelos clubes de amadores europeus.

A natureza, na maior parte da série, atua apenas como entorno para o trabalho que está sendo desenvolvido e o rio ocupa o primeiro plano, conferindo distanciamento para que a ação possa ser registrada em seu ciclo. Em "Bateada em Tássaras - O. Preto" o garimpeiro está com a peneira, utensílio empregado para a coleta de ouro no rio (Fig. 54); "Moendo cascalhos em Tássaras - O. Preto" há a seleção do material que havia sido colhido, é quando entram em cena os chefes dos trabalhadores (Fig. 55); e, depois, na fotografia de mesmo título "Moendo cascalhos em Tássaras - O. Preto" aparece apenas os chefes observando e inspecionando o produto final dessa exploração (Fig. 56).

Cumpre observar que essas são as únicas imagens, dentro do corte cronológico aqui estudado, da natureza modificada pela ação humana, que se encontra num estado de desequilíbrio. O interesse, no entanto, é estabelecer uma relação de propriedade com 
o lugar. O vínculo de Alberto de Sampaio com essa natureza, aqui sim, "produtiva”, é pessoal, e não se trata de um encontro com a outra cultura, numa viagem de turismo. Temos uma atividade de exploração economicamente rentável, por isso a presença da natureza alterada, em que os cascalhos modificam o próprio curso do rio.

\section{A natureza como marca de distinção}

Alberto de Sampaio começa sua produção com uma perspectiva ambígua sobre a natureza. Inicialmente como cenário de fruição para o homem, mas com importância pequena nas imagens. Depois, no século XX, a natureza assume o controle, domina o espaço da representação de cidades como Petrópolis e torna-se, além disso, tema, argumento principal. Nesse momento, se estabelece a diferença de escala, pois esse amador não apreciava os panoramas que, para ele, serviam apenas para fazer um exercício sem ter relevância na produção como um todo. O que interessava para Sampaio, então, era a dimensão pequena, o sentimento de proximidade e de maior integração entre o espectador e seu objeto.

É na fotografia de natureza que tais problemas se apresentam em grau mais elevado, pois este é, de fato, o eixo em que se explora e consolida um determinado modo de ver que será transplantado para outros conjuntos temáticos. Vale ressaltar que a prática continuada no gênero era também de grande representatividade para o fotógrafo que se estabelecia como amador naquele momento. Era na representação da natureza que se podia dedicar a produzir imagens sem nenhum objetivo específico - não precisava nem atender às expectativas do grupo familiar, mesmo quando havia registros dos parentes e amigos mais próximos. Ele podia aqui, portanto, fazer excursões livremente apenas para que suas imagens indicassem seu modo de apreciação e interação com a natureza, assim como sua orientação cultural pautada pela partilha de conhecimentos de ordem estética. 
Distanciava-se assim completamente das questões debatidas no campo da pintura de paisagem, em que o problema da identidade nacional seria relevante.

Mas a questão não ficava restrita aos amadores, afinal se havia "vida comunicativa da paisagem", de que fala Afrânio Peixoto (1962: 58) em sua referência a Petrópolis, em A esfinge (1911), a natureza havia-se convertido também em recurso, um tipo de linguagem comum, para aqueles que queriam se diferenciar. Num momento de grandes mudanças e instabilidades, em que Petrópolis vira teatro de determinada representação social, onde se evidenciará o desejo de manutenção de privilégios, tudo o que se convertia em elemento de diferenciação seria altamente mobilizado.

Nesse contexto, as fotografias de natureza participam de um processo mais amplo, em que se podia revelar não apenas o "fino gosto" de amadores como Alberto de Sampaio. São indicativas de que certo "desprendimento" havia sido convertido em elementos de diferenciação. A grande valorização das fotografias de paisagem e formas de agrupamento social derivadas desse gênero, como a excursão, se deve sobretudo a esse componente.

Haveria certamente falta de perspectiva crítica na produção imagética desses amadores. Questões mais amplas como preservação da natureza, preocupação que se coloca desde o século XIX, não teriam a menor relevância para tais produtores de imagens. Petrópolis, por exemplo, já havia sido reflorestada na década de 1880 (pelo Major Archer ${ }^{79}$, que fez também o reflorestamento da floresta da Tijuca, no Rio de Janeiro), em áreas de mananciais e outros trechos do centro da cidade cujas árvores haviam sido derrubadas, em grande parte, para produção de carvão.

Em outras regiões o problema era notado inclusive pelos visitantes, como Georges Clemenceau, que deixa relatos importantes sobre o que viu no Brasil em sua

${ }^{79}$ O Major Archer foi vizinho de Alberto de Sampaio na década de 1880. Ele, da mesma forma de Bento Sampaio, comprou o terreno e construiu a casa. Em 1906, essa residência, já com um segundo dono, foi adquirida por João Teixeira Soares (Cf. Sampaio, 2008). 
visita em 1910, na matéria publicada no ano seguinte na revista L'Illustration, sobre trecho de seu trajeto de trem até a fazenda Santa Alda: "Je ne dirai rien du voyage. Des collines ravagées par l'incendie, comme toujours (13/5/1911: 387, n. 3559)».

Porém, sinais dessa destruição, não integrariam as preocupações de Sampaio. Para ele, a natureza teria papel afirmativo. Mas seu papel seria mais amplo. No caso de Petrópolis, especificamente, a natureza era um ingrediente daquele espaço, da mesma forma que as festas, exposições, recepções na residência de diplomatas. Estaria integrada como mais um meio de afirmação de homens que podiam falar uma língua comum, erudita, em que se valorizava sobremaneira a cultura artística. 


\section{ESPAÇO DOMÉSTICO}

A série de fotografias produzidas por Alberto de Sampaio no espaço doméstico é a maior dentro do total do acervo. Trata-se de imagens de pessoas ligadas à família extensa (núcleo primário, parentela e agregados), registradas no ambiente doméstico (principalmente a casa do fotógrafo em Petrópolis e, em menor número, nas de outros membros da família, incluindo as fazendas). São 574 fotografias: entre 1888-1904 há apenas 12 imagens conservadas; já entre 1905-1914 temos 562 registros. O aumento das fotografias foi acompanhado por mudanças na temática com, por exemplo, a introdução da infância e, ainda, no que se refere aos dispositivos visuais, seja na composição, seja na iluminação do quadro.

Aqui há uma diferença importante para os registros de família que tinham a natureza como cenário, apresentados anteriormente. As pessoas fotografadas nesses espaços externos podiam interagir com o entorno composto por vegetação, montanhas e mar. No caso do ambiente doméstico, o fundo, ao contrário, conta pouco e, em muitas situações, podia até mesmo ser anulado com o uso de um painel em tecido, evidenciando assim seu peso secundário para o sentido da imagem.

Por isso, utilizaremos o termo retrato apenas para as fotografias em que as pessoas estão no ambiente doméstico, porém, com restrições. A definição do retrato canonizada pela pintura e depois na fotografia profissional, de maneira genérica, está vinculada a algo como sua essência interior e ao registro do ser social, que remete mimeticamente ao indivíduo que está sendo documentado, e, ao mesmo tempo, revela elementos de seu lugar na sociedade. Alberto de Sampaio não ignorava esta noção do 
que era o retrato. Isso se evidencia quando ele utiliza nominalmente o termo em seu caderno de anotações, se referindo sempre às cenas com poses formais, tal como encontradas nos estúdios fotográficos. Sua produção no universo doméstico, no entanto, extrapolou estas questões. Há, por exemplo, registros com intenção narrativa, em que Sampaio realiza duas fotografias em seqüência, cujos títulos passam a se referir à ação desempenhada pelas pessoas. Portanto, a denominação "retrato" será utilizada aqui de maneira parcial.

É importante destacar que essa alta produção de fotografias de família, realizada exclusivamente no ambiente doméstico, não se deve apenas a uma questão de conveniência, por ali ser mais fácil manusear câmeras, tripés e negativos. De fato, o gênero retrato estava associado ao modelo difundido pelos estúdios profissionais e, portanto a espaços internos. Inicialmente havia um condicionante técnico: era necessário, por exemplo, tempo prolongado de exposição, um tipo de imobilização do corpo perante a câmera, para que a tomada pudesse ter nitidez. Mas as convenções formais relacionadas a certa postura corporal (homem sentado, mulher em pé, etc.), à indumentária e ao cenário (fundos pintados, cortinas, mesas, cadeiras, colunas, balaustradas, etc.), que conferiam sobriedade e respeitabilidade às cartes de visite, se tornaram mais importantes do que as necessidades de ordem técnica (Cf. Turazzi: 1995: 13).

Dentro desse contexto, mesmo quando a fotografia de grupo era realizada no espaço doméstico se repetiam tais convenções. Um caso semelhante foi estudado por Mariana Muaze (2008: 171) que analisou a coleção de retratos da família Ribeiro de Avellar, e a comparação pode ser útil. Neste conjunto existem séries em formato carte de visite, realizadas na própria fazenda da família - que, como já nos referimos, estava situada em Vassouras, no Vale do Paraíba, estado do Rio de Janeiro - por um fotógrafo 
amador itinerante, Manoel de Paula Ramos, em 1870. Ali, apesar de os retratos terem sido realizados no quintal da fazenda, eles reproduzem exatamente o modelo de fotografia difundida pelos ateliês. Foi necessário então adaptar o cenário no quintal utilizando-se o mobiliário da própria fazenda, com cadeiras, mesa, tapete e cortinas. Por isso, segundo a autora, da mesma forma que as visites dos estúdios profissionais, tais fotografias revelavam a hierarquia "vivenciada no interior do núcleo familiar", "com a figura paterna ao centro, "elevado a autoridade máxima", a esposa de pé, como aquela que cuida do grupo, e os filhos denotando "respeito, admiração e confiança".

Embora não sejam conhecidos outros exemplos como este (e ser difícil identificar um padrão a partir desse exemplo) sabemos que fotógrafos profissionais ofereciam habitualmente a realização de retratos em estúdio e "a domicílio" ${ }^{80}$, como indicam diversas propagandas do período. Podemos supor então que, para os grupos sociais elevados e, possivelmente, mais isolados dos centros urbanos, era de fato comum contratar algum profissional para prestar serviços na residência.

Nessa perspectiva, o ambiente doméstico seria um espaço que tinha alta importância para a representação da família. Quando havia o fotógrafo amador como membro do próprio grupo, certamente, haveria grande possibilidade de ali ocorrer grande produção de imagens como aconteceu com Alberto de Sampaio. Até porque o gênero retrato era muito valorizado, sendo considerado o mais difícil para o iniciante. Os textos dos diversos manuais e revistas ilustradas do período, por diversas vezes, aconselhavam aos fotógrafos a serem cautelosos. Seria desejável que o amador dominasse primeiramente a técnica e as convenções estéticas, para que pudesse evidenciar muito mais do que traços fisionômicos da pessoa registrada. Somente assim,

\footnotetext{
${ }^{80}$ Dois fotógrafos que ofereciam esse duplo serviço, retratos no atelier e "a domicílio", eram David Latino \& Franklin em dois estúdios situados nas ruas da Quitanda e Sant'anna, no centro do Rio de Janeiro. Havia um incremento de cerca de $30 \%$ nos preços quando as fotografias eram feitas no ambiente doméstico, como indicam as propagandas publicadas no Almanach do Paiz, de 1910.
} 
segundo essa literatura, se produziriam fotografias com traços e aspectos da personalidade do indivíduo.

Merece ser ressaltado ainda que existe vasta produção bibliográfica voltada para a análise dos usos e funções da fotografia de família e que tratam da circulação e consumo de tais registros, dentro e fora do ambiente doméstico. Há autores que abordam os aspectos materiais do suporte fotográfico, seu papel fundamental para conferir sentido de continuidade ao grupo, possibilitar a partilha de sentimentos e posses, etc (Hirsh, 1999; Holland, 1998). Pierre Bourdieu (1965:39) foi um dos primeiros a destacar que a fotografia tinha como função principal reforçar o sentimento de integração do grupo familiar e, por isso, ele ressalta a grande normatividade e os cânones muito fortes para tais imagens, mesmo em produções recentes. Seguindo abordagem, em parte semelhante, se estabeleceu na historiografia associada à produção amadora a noção de que a fotografia de família marca momentos de mudanças, o que Richard Chalfen (1987: 96) irá destacar como "change": "moments of positively valued change, marked by parties, official recognition, or public celebrations”.

As fotografias de Alberto de Sampaio dialogam com essas referências, havendo certamente elementos de continuidade. Contudo, fica patente que não havia uso documental, ele não está preocupado com momentos de passagem (nascimentos, casamentos, etc). O problema da passagem do tempo será, consequentemente, minimizado, havendo a inserção do sentido lúdico na imagem. Para fins de análise de tal problemática, abordaremos primeiramente os espaços e comportamentos. Depois, questões associadas ao uso improvisado de materiais no ambiente doméstico, à encenação e humor, todos componentes da fotografia de família da primeira década do século XX. 


\section{Os espaços e os atores da fotografia de família}

No acervo de Alberto de Sampaio havia menor quantidade de imagens com algum interesse documental. Embora quantitativamente haja menor relevância, a série que aqui apresentaremos é significativa e merece ser ressaltada, pois reitera a importância do espaço doméstico, indicando certo funcionamento familiar que integrava questões espaciais e dos personagens que ali habitavam.

Começaremos pela casa, que foi representada numa vista da rua (7 fotografias). Uma das primeiras tomadas que documentam elementos arquitetônicos é "Casa rua Souza Franco com as crianças" (Fig. 57) de 1903. A imagem está centrada na construção e o espaço do entorno é praticamente anulado. Apesar de haver terreno circundante quase não o percebemos, pois, com o sentido vertical, há maior aproximação do edifício. Mas o fotógrafo acentua a passagem da rua para o interior doméstico, com a tomada em perspectiva, valorizando a visão do transeunte. Por isso, há todos esses elementos de transição como calçada, gradil e jardim.

É preciso considerar que situar-se fora da residência para registrar o interior revela maiores implicações. Os estudos sobre ornamento na cidade de São de Paulo, desse mesmo período, de Solange Ferraz de Lima (2001: 23) nos auxiliam a entender tal estratégia de posicionamento. Segundo a autora, os "aparatos visuais" integrantes da arquitetura dos palacetes paulistanos do período, como gradis e jardins seriam elementos funcionais que "hierarquizavam os espaços" e serviam, portanto, como “moldura para a casa”. Todos esses recursos materiais estabeleceriam certa distância da moradia de perfil burguês para o espaço público, sendo um elemento a mais para corroborar os atos de distinção social.

É exatamente nesse espaço transitório, na calçada onde está a mureta com gradil, que enquadra a residência, onde se posiciona a maior parte do grupo com as três 
crianças e empregada. Eles estão ali mais relaxados, sentados de maneira informal e, no segundo pavimento, temos outra criança. $\mathrm{O}$ grupo não está posicionado apenas para conferir escala ao cenário; há conotação simbólica, pois eles servem também para particularizar o edifício. Vale ressaltar que esse tipo de tomada era realizada comumente por fotógrafos profissionais contratados para documentar propriedades, que podiam ser residências ou estabelecimentos comerciais. Em geral, utilizava-se o recurso de distribuição das pessoas por janela ou porta da edificação, para indicar o pertencimento ao lugar.

Numa outra fotografia, de 1907, há o registro da fachada, praticamente do mesmo ponto de vista (Fig. 58). Mas a casa havia sido alterada, não contava mais com a varanda do segundo pavimento (era a segunda reforma - a primeira foi feita na década de 1890 para o acréscimo de um andar), e tinha sua aparência definitiva (permanece assim até os dias atuais). A composição, no entanto, se mantém com a tomada vertical centrada no edifício e as pessoas da família permanecem situadas nos espaços de comunicação com a rua: varandas e janelas. Mas destaca-se aqui muito mais a fachada, pois a vegetação densa na parte esquerda cobre a visão da parte interna, diferentemente da imagem anterior. Os indícios de pertencimento também se acentuam com a presença da esposa de Sampaio, Cecília, no segundo andar, que completa o quadro da representação familiar. Convém lembrar que o estilo arquitetônico não seguia um estilo definido, como era muito comum nas casas encontradas em Petrópolis. Há aqui, inclusive, treliças em madeira no guarda-corpo das varandas dos dois pavimentos, elemento construtivo que nos remete aos antigos muxarabis, referência à arquitetura colonial de origem portuguesa, muito distante do padrão eclético francês, tão em voga no período, nesta cidade. 
Certo despojamento com a ornamentação mais valorizada no período poderá ser notada no interior da residência em que há um conjunto pequeno de fotografias dos ambientes (14 fotografias) sem a presença de pessoas. Embora tenhamos poucas imagens, cumpre lembrar que tais registros são muito importantes devido ao caráter enciclopédico, pois ali estão documentados, enquanto tema, locais de mediação com o espaço externo, como sala de estar, jantar e gabinete - lugares de recepção ou trabalho.

Nas imagens das salas de estar, destaca-se o interesse na fotografia como elemento decorativo. Num dos registros representativos dessa série (Fig. 59) temos o espaço de entrada da casa tomado perpendicularmente à porta principal (que ficava na lateral direita). No primeiro plano, uma pequena mesinha de apoio contém um álbum das cartes de visites, que ficava normalmente à mostra nesses ambientes. Na parede ao fundo, emoldurada pelas portas com cortinas, estão dispostas pinturas e fotografias, que ocupam o espaço central da cena. Em termos quantitativos há mais fotografias: tanto na pequena estante com porta-retratos de pais, sogros e tios daquele núcleo familiar (realizadas em estúdios profissionais), como os registros de filhos de Alberto de Sampaio de autoria do próprio amador que estão na parede. Mas é nas pinturas que a moldura aparece diferenciada com material ornamentado. Isso indica haver diferença de tratamento e de disposição da imagem técnica, daquela que tinha sinais de sua feitura manual, portanto, considerada nesse interior como mais nobre.

Situação semelhante irá ocorrer no registro do lado oposto da mesma sala, em outra cena típica desse conjunto: "Salla de visitas em minha casa S. Franco" de 1905 (Fig. 60). As fotografias expostas, nesse caso, estão num móvel. São imagens individuais ou de grupo de filhos de Alberto de Sampaio e sua esposa, realizadas possivelmente por Jorge Henrique Papf que, como vimos, era o profissional que registrava essa família. Mas aqui não temos mais o porta-retratos, havia apenas os 
cartões em formato carte cabinet, apoiados livremente; alguns deles estão até mesmo empenados. A organização também não tem nenhuma rigidez. Como na estante existem vasos de vários tamanhos, em alguns casos as fotos estão atrás desses objetos, aleatoriamente dispostas. A diferença de tratamento é notória, inclusive quando se trata de pinturas de Alberto de Sampaio. Na parede, por exemplo, há um quadro pequeno, com moldura em madeira, de autoria desse amador. É uma aquarela que está destacada, posicionada centralmente em relação ao sofá, de um homem sentado a cavalo num campo.

Vale notar ainda que o álbum das cartes de visite, na fotografia anterior (Fig. 59), estava numa mesa em formato octogonal, situada no primeiro plano. Já nesta última imagem com título e data (Fig. 60) o álbum foi deslocado para outra pequena banqueta, coberta com tecido, posicionada ao lado da cadeira ao fundo. Este certamente era o local de origem desse material, pois assim se facilitaria seu manuseio por aqueles que não pertenciam ao núcleo familiar e que iriam entrar na "salla de visitas", como o próprio Sampaio nomeia. Ter o álbum à mostra na sala era um hábito comum nas residências de elite, como muito bem ressaltou Vânia Carneiro de Carvalho (2008: 93), pois "as fotografias produzidas em estúdio e que apresentavam o retratado mergulhado em um cenário considerado artístico eram tidas como demonstração de bom gosto e serviam para atestar a capacidade de expressão criativa e progresso pessoal dos proprietários". Por isso, tais imagens expostas no "álbum da sala", segundo a autora, serviam para afirmar o "status" da família e "compartilhavam com os demais objetos de decoração a tarefa de declarar o comprometimento com a cultura burguesa".

Alberto de Sampaio, no entanto, não utiliza apenas dessa maneira (em álbuns de carte de visites), as fotografias como elemento decorativo. Num outro registro desta sala, nota-se que imagens, mesmo importantes, podiam ocupar papel secundário em 
relação a outros objetos no interior doméstico (Fig. 61). Aqui foi registrado um espaço pequeno, a parede com a estante em madeira sustentando inúmeros bibelôs, vasos e estatuetas. Ao fundo temos duas fotografias coladas num cartão em grande formato: na primeira prateleira aparece Cecília na residência paterna, segurando o violão e, na segunda, Alberto de Sampaio numa imagem típica de formatura (possivelmente feita após a conclusão do curso de Direito). Esse trecho situado entre uma janela e a porta, que se comunica com a parte exterior, contém duas imagens importantes para o casal, realizadas por algum profissional, contudo, estão dispostas também aleatoriamente.

Todos esses exemplos demonstram dois eixos que parecem se contrapor ao uso que Sampaio faz das fotografias no interior doméstico: por um lado, a importância menor em relação à pintura denotada pelo acabamento mais simplificado dos passepartout e ainda pelo uso por vezes secundário de retratos como fundo; por outro, há diversificação e registros em todos os lados da casa - além do "álbum de sala", as imagens estão nas estantes, mesas e paredes. Isso significa que a fotografia era flexível, dinâmica, adaptável às circunstâncias e, por isso, ela trás, diferentemente do quadro, as marcas de seu uso, do material que pode inclusive entortar. E, mesmo assim, fica disposta na entrada da casa.

Tal flexibilização pode ser encontrada de maneira até exacerbada em publicações direcionadas ao público amador. O Amateur Work, por exemplo, revista publicada em Londres na última década do século XIX e destinada à prática do amadorismo de maneira mais ampla - desde jardinagem, marcenaria, pintura até fotografia - trazia tópicos especiais sobre o uso dessas imagens na decoração. Mas ia muito além, havia diversos artigos que ensinavam como incorporar as fotografias a mesas de centro, biombos e diversos objetos de decoração. 
No Brasil não temos nenhuma referência de utilização de imagens fotográficas, nesse período, de maneira semelhante às sugestões do Amateur Work. Porém fica indicado haver interesse mais amplo nesse público (também produtor de fotografias), em dispor tais registros de maneira diversa no interior doméstico. Por isso, é possível supor que as fotografias decorativas na casa dos amadores não se restringiriam ao que destaca Nelson Schapochnik (2002:502) em relação à ornamentação dos palacetes e casarões do período: “dependuradas nas paredes ficavam as fotografias de familiares emolduradas em diferentes padrões de passe-partout".

A casa do fotógrafo amador seria certamente diferente, pois ali poderiam ser exibidos socialmente não só as imagens da família, de sua autoria, mas sobretudo uma segunda identidade, que gozava de certa respeitabilidade. Exercer a fotografia de forma apenas amadora, nesse momento, representava, pois, um novo tipo de status, daquele que dispunha de conhecimentos compartilhados socialmente em revistas de todos os gêneros. Era uma atividade de alta dosagem de interação social, como no caso dos clubes, e trazia suas marcas de distinção.

Nos demais espaços sociais da residência, não se percebe, no entanto, a mesma importância da fotografia como elemento decorativo. Por exemplo, em "Mesa de jantar em minha casa" de 1905 (Fig. 62), temos apenas o ambiente já preparado para a recepção com jarras, pratos, copos, talheres e guardanapos ordenados. Aqui parece ter muito mais importância o espaço como marca de individuação de que fala Schapochnik (2002:504), que trazia uma "aura de sofisticação e refinamento inspirada na cultura européia". O direcionamento da imagem para a janela ao fundo representa simbolicamente essa comunicação com o exterior. Jeffrey Needell (1993: 180) também destaca a importância desses espaços sociais, no caso especificamente das residências de Petrópolis, como locais de exibição "do gosto e da riqueza compatíveis com os 
valores eurófilos". É preciso ressaltar, porém, que nas fotografias, até mesmo das salas de estar e fachada da casa de Alberto de Sampaio, encontramos um interior e arquitetura que revelam apenas sutilmente aquela profusão de objetos decorativos característico do padrão eclético. As referências à treliça em madeira das varandas, que remete aos antigos muxarabis, e as cadeiras em palhinha do interior se distanciam certamente do que era reconhecido como o alto padrão de arquitetura e mobiliário. Tudo aqui parece revelar um tipo de mistura em que vale, não sabemos se por motivos econômicos, também o modelo lusitano. O contraste se evidencia, por exemplo, na única fotografia da casa do sogro de Alberto de Sampaio, João Teixeira Soares, que tinha sua sala de estar ricamente decorada com tecidos ornamentados que cobriam as paredes, estavam nas cortinas e estofados modelo Luís XIV, que revelavam, portanto, o gosto tipicamente francês de certas moradias de Petrópolis.

Tal preocupação em valorizar os atributos decorativos, no entanto, não estaria presente nas fotografias dos locais de trabalho, uma vez que eram nas residências que se desempenhavam diversas atividades profissionais. O próprio Sampaio se anunciava como advogado no conhecido Almanak Laemmert nos primeiros anos do século XX, fornecendo o endereço da casa da família em Petrópolis. Então, as fotografias deveriam evidenciar outros aspectos da mediação com a vida pública, compartilhada ali no interior doméstico. Uma imagem que reúne as características da série é "Minha mesa no gabinete" de 1905 (Fig. 63). A mesa em primeiro plano está numa completa desorganização contendo papéis, máquina de escrever, canetas, luminária e, inclusive, um chapéu masculino virado para cima. Há até certo exagero na disposição quase caótica dos materiais e não temos a presença humana; então é na exacerbação da função que o espaço desempenha, a partir dos objetos, que a imagem pode completar seu sentido. A bagunça é, nesse caso, um recurso a mais para validar a atividade exercida. 
Completando o quadro, a janela fechada ao fundo, com a fina cortina em tecido bordado, indica que tudo está concentrado na ação que ocorre na mesa, diferentemente da sala de jantar, em que há comunicação com o universo exterior. Aqui há outra mediação, mais intelectual e, portanto, esse era um lugar de introspecção e de um tipo de prazer solitário. Vânia Carneiro de Carvalho (2008: 47) também destacou que os escritórios particulares eram os únicos lugares da casa que tinham a desarrumação como valor positivo, circunstância validada até mesmo nos manuais destinados à organização doméstica do período.

Mas o grande número de fotografias ali realizadas registra os atores. São as pessoas que moravam ou visitavam o lugar. Trata-se dos membros da família extensa: esposa do fotógrafo e os filhos, sogros, cunhados e sobrinhos. Havia também um grupo secundário formado exclusivamente por homens próximos à família, que podiam ser vizinhos, engenheiros de estradas de ferro, ou mesmo sócios do Club dos Diários em Petrópolis, pessoas que mantinham com a família relações próximas e afetivas. Geralmente, tinham tratamento diferenciado nas fotografias, de maneira mais formal, como um visitante. Um terceiro grupo, bem mais reduzido, era formado por empregados, em sua maioria mulheres, que cuidavam dos filhos de Sampaio ou de crianças ligadas aos parentes mais próximos.

É preciso ressaltar que estas imagens revelam alto grau de "domesticidade", pois não temos nenhum lastro da vida social existente em Petrópolis, da qual o próprio Sampaio era um ativo componente. As pessoas que visitavam e se deixavam retratar mantinham com o grupo relações próximas e não estavam ali apenas por ser um lugar de recepção social. Fazer tal diferenciação é importante, uma vez que na cidade serrana os jantares privados concorriam em prestígio com aqueles realizados nos clubes. Os jornais inclusive forneciam detalhes sobre esses encontros, publicando até mesmo o 
menu oferecido. Com vimos, através dessa intensa vida social essas pessoas mantinham certa visibilidade pública.

Isso não quer dizer que na residência de Alberto de Sampaio ou de seu sogro, João Teixeira Soares, não ocorresse nenhum tipo de encontro com a recepção de pessoas que estavam fora do núcleo constituído por amigos mais próximos. Como vimos, eram constantes as menções a políticos, engenheiros e militares que estiveram na fazenda Santa Alda. Podemos supor que o espaço doméstico em Petrópolis fosse utilizado para objetivos e compromissos semelhantes. No entanto, o que se convertia em fotografias, ou melhor, o que se selecionava para ser registrado eram as cenas com pessoas que mantinham com Sampaio elos afetivos.

Seguindo os espaços mais importantes para a produção de fotografias, vem em primeiro lugar o quintal (363 fotografias). Esse era o cenário predileto para tomadas formais e, ainda, registros com forte grau de encenação. No quintal também havia as cenas de grandes grupos, onde se registravam a parentela e amigos, diferentemente dos espaços internos em que predominavam os registros individuais ou com poucas pessoas. De acordo com essas imagens, o quintal desempenhava diversas funções: podia ser o lugar para receber amigos, almoçar com a família, fazer brincadeiras ou para produzir retratos que dialogavam com o universo dos profissionais.

O espaço de entorno, nesse caso, não tinha muita importância, podia até ser anulado quando se utilizam tecidos e painéis para criar um fundo neutro como numa fotografia típica da série, "Luluta" de 1910 (Fig. 64) - filha do fotógrafo registrada em cima de um lençol branco preso na parede da residência. Posteriormente, na ampliação, os sinais do ambiente externo seriam suprimidos, o que valia então era o corpo num lugar indeterminado. A menor importância do entorno se revela até mesmo quando apareciam alguns sinais desse quintal como num registro bastante representativo, de 
Cecília com três de seus fillhos (Álvaro, Bento e Alberto) em 1906 (Fig. 65). A parede que serve de fundo para a fotografia, nesse caso, é simples. O chão é de terra e as crianças estão apoiadas numa pequena cerca e escada de madeira, que auxiliam a compor o cenário nada rebuscado. Há certa formalidade nas posturas da mulher e crianças, contrastando com a simplicidade do ambiente e com a indumentária doméstica, em que se destaca o avental feminino. No quintal não haveria também preocupação em esconder sinais do uso daquele espaço que podia mostrar os varais e roupas estendidas, como aparece em diversas tomadas, entre as quais destacamos “Cecília e creanças no páteo de casa” de 1907 (Fig. 66), em que há um pequeno gramado, chão de terra, bancos (onde o grupo está sentado), roupas secando e uma edícula ao fundo.

A situação seria um pouco diferente com o tratamento de "visitantes". Eles eram retratados, em muitos casos, de maneira mais solene, seguindo os graus de importância conferidos à figura paterna, materna e filhos conforme fica ressaltado em “Família Ed. Rudge” de 1910 (Fig. 67). Esta é uma fotografia padrão desse conjunto e que demonstra haver, de maneira preferencial, hierarquia no posicionamento do grupo: o chefe de família aqui está destacado com o corpo ligeiramente inclinado; o grupo ao fundo, composto por sua esposa e filhos, está formalmente posicionado, com a mulher ao centro, como aquela que cuida e exerce, por isso, papel central para o núcleo. Todos eles têm postura corporal contida, com braços para traz ou estendidos e o cenário é composto pela vegetação, simulando a presença da natureza no espaço doméstico. Trata-se de posicionamento e de gestos que revelam traços daquilo que Carlos Eugenio Marcondes de Moura (1983:11) denominou como o padrão do "marido patriarcal", em que o grupo de família se dispõe em função da figura principal masculina. De fato, é possível supor que, em tais circunstâncias, Sampaio tinha oportunidade de afirmar sua 
identidade como fotógrafo amador, mesmo que a demonstração de seu domínio da técnica e das convenções vigentes na retratística do período ocorresse apenas para o núcleo mais próximo. Era um ato, de alguma forma, de apresentação social de suas habilidades. Possivelmente, tais retratos seriam trocados, dados de presente aos amigos, como fica evidenciado em diversas cartas de Cecília, que sempre se refere a imagens que deveriam ser enviadas para parentes e amigos.

Já com os membros da própria família Sampaio havia bem menor preocupação com esse tipo de organização formal. Em "Minha família" de 1911 (Fig. 68), uma cena típica desse grupo no quintal, Alberto de Sampaio e Cecília estão junto aos seus sete filhos, todos posicionados em fileira seguindo as faixas etárias. A preocupação hierárquica, relacionada às diferenças de gênero, se reduz ao interesse de marcar as variações de tamanho das crianças. Os pais ficam posicionados de maneira quase didática, integrando, eles mesmos, a ordenação do grupo. O espaço é amplo mas, como em geral ocorria, não havia preocupação cenográfica com o fundo, a área era simples e não houve nenhuma intervenção no espaço.

Nos registros do casal Alberto e Cecília tal diferença se tornava mais explícita ainda. Aqui o problema da hierarquia seria substituído pela expressão de sinais de afetividade. Em "Eu e Cecília" de 1910 (Fig. 69), uma imagem significativa da série, o casal se posiciona frontalmente à câmera e não há destaque para a figura masculina. Os dois estão muito próximos e ambos pousam as mãos sobre os ombros do cônjuge, ressaltando a união. Apesar de a fotografia ter sido realizada em direção à parte frontal da residência, onde havia maiores cuidados com o jardim, tudo está fora de foco, corroborando a idéia de que havia mínima interação entre aqueles que estavam sendo registrados e o cenário. 
No caso do registro de crianças, haveria no quintal comportamento com grau elevado de informalidade. Na série, quando temos o título, há referências mais genéricas como "Effeito do sól nos meninos" de 1904 (Fig. 70). A fotografia aqui foi tomada numa perspectiva descencional e tem como fundo uma parte qualquer do terreno, reiterando a menor preocupação com o entorno. As crianças (Álvaro, João, Bento e Alberto) usam roupas domésticas, uma delas inclusive está de camisola. A desmobilização do corpo ocorre em função da circunstância que se queria ressaltar. Desta maneira, a legenda apresenta, para ele, algo que nem sempre está explicitado no conteúdo das fotografias.

Cumpre lembrar que a maior parte das fotografias no ambiente doméstico registra crianças, ora em poses convencionais, ora em situações informais, com adultos, ou sozinhas. De fato, desde o século XIX havia valorização da infância como uma etapa da vida que merecia atenções e cuidados especiais. É o que destaca Mariana Muaze (2008: 156) ao se referir aos novos hábitos da classe dominante, no Brasil, que tinha como modelo as famílias burguesas européias. Nesse quadro de alterações, as crianças passavam a ser fotografadas mais novas, com roupas sofisticadas e brinquedos importados. No entanto, as mudanças observadas na escrita epistolar e nos livros pedagógicos, que começavam a tratar de questões como afetividade e jogos infantis, não aparecem nas fotografias, conforme indica a autora. No formato carte de visite se difundia apenas a figura típica da criança, da mulher e do homem. Não havia, portanto, possibilidade de haver variações nessa representação, uma vez que, como vimos, a fotografia cumpria uma função muito clara de reafirmar a imagem de indivíduos "respeitáveis" que pertenciam a um determinado extrato social. Mas no caso estudado pela autora, na coleção das cartes de visite da família Ribeiro Avellar, as crianças figuravam em apenas $13 \%$ do total dos registros. Já nas imagens produzidas por 
Sampaio há total inversão, pois as crianças representam cerca de $85 \%$ das imagens realizadas no ambiente doméstico. Tal presença maciça do universo infantil, porém, não era exclusiva desse amador. Com iremos destacar a seguir, as crianças simbolizariam de maneira exacerbada, a diferente relação que iria se estabelecer entre a prática fotográfica e o grupo familiar, como sendo sobretudo divertimento.

Os empregados, como personagens que integravam esse ambiente, também foram registrados, na sua maioria, no quintal (15 fotografias). Em geral, como já destacamos, eram as mulheres, "mães-pretas", que, por terem a designação de cuidar das crianças, integravam de alguma forma o núcleo familiar. Vale observar que são nesses únicos casos que crianças recém-nascidas foram registradas por Alberto de Sampaio. É como se essa primeira fase da vida tivesse apenas a participação das empregadas, pois os pais ou demais membros da parentela nunca foram fotografados juntos aos bebês. Em alguns casos Sampaio explorava inclusive a dimensão estética da composição como na cena em que vemos a empregada com a criança e o fundo neutro no quintal (Fig. 71). A imagem foi depois ampliada, colada num cartão e colorizada, tendo destaque no conjunto do acervo. Pelos títulos das fotografias, no entanto, observamos que essa inserção na família ocorria dentro de um quadro social muito específico, pois estas mulheres raramente eram referidas pelos nomes, mas como "babá" ou “criada". Também, em pouquíssimas situações - dois retratos - apareciam com seus próprios filhos.

A importância que Alberto de Sampaio conferia ao quintal certamente não constituía uma exceção na prática da fotografia de família do período. Os estudos de Miriam Moreira Leite (2001:186) ressaltam que até mesmo nos acervos de outros grupos sociais, como os imigrantes, havia valorização do quintal. Segundo a autora, após analisar um conjunto de fotografias realizadas em São Paulo no início do século 
XX, a importância dos “espaços intermediários" como o quintal e varandas se devia a questões técnicas, pois era ali que havia as melhores condições de iluminação para realizar as fotografias. Mas estes locais eram, ao mesmo tempo, espaços diferenciados por desempenharem uma função muito mais simbólica, que seria de mediação entre o lugar de abrigo, o interior doméstico, e a rua. Portanto, permitiam evocar, numa segunda significação, o sentido de "passagem do interior para o exterior".

A outra área que tem grande quantidade de fotografias está no interior da residência. É o espaço de recepção social composto por sala de estar, jantar, biblioteca e gabinete de trabalho (125 fotografias). Mas aqui, diferentemente das poucas cenas temáticas dos mesmos ambientes, mostrados anteriormente, há menor importância para o cenário. As tomadas com pessoas se concentram, ora nas ações desempenhadas, ora no registro do indivíduo enquanto tema. No primeiro caso, o cenário será apresentado em decorrência da interação do retratado com o espaço e, no segundo, poderão ser utilizados também fundos neutros que anulam completamente a importância do entorno doméstico.

Nestes locais, a mulher era registrada preferencialmente de acordo com a função exercida no ambiente, como aquela que cuidava dos filhos e praticava a leitura com objetivos de lazer, como fica indicado em "Cecília lendo no Gabinete" de 1905 (Fig. 72). A fotografia tem as características principais encontradas na série. O espaço é restrito com o ambiente de trabalho bastante desorganizado; na mesa há papéis, cadernos e livros espalhados sobre a toalha que indicam presença feminina. Ao fundo, na parede, há fotografias de paisagem presas de maneira aleatória e pinturas emolduradas (em que percebemos somente um trecho devido à altura). A mulher está de perfil concentrada na atividade de leitura, utilizando avental, um indício do trabalho doméstico. Em sequência Sampaio registrou o mesmo ambiente com os filhos do casal 
em volta de Cecília (Fig. 73). Aqui o posicionamento da mulher permanece, havendo um desdobramento das funções domésticas femininas de cuidados com a prole, no caso, em referência à educação dos filhos. Inclusive, uma das crianças está segurando uma caneta tendo o corpo inclinado, indicando a atividade de estudo a ser desempenhada no gabinete.

Quando se trata da figura masculina, as imagens irão representar o universo do trabalho em ambientes como o gabinete e a biblioteca. Não há cenas de homens em salas de estar, nem mesmo os visitantes e, em geral, nesses locais que fazem alusão ao trabalho, o destaque está nas mesas com papéis, canetas, livros e jornais. Uma cena típica é "Meu retrato no gabinete" de 1910 (Fig. 74) em que Sampaio foi fotografado por um de seus filhos, Álvaro, como aparece registrado no caderno de anotações. Mas aqui a desorganização está concentrada apenas na mesa, que tem objetos de outra ordem: busto, pasta de couro, livros, bandeja com bule, xícaras e cinzeiro. Não havia apenas material de leitura, mas também de certo consumo, indicando haver maior permanência no lugar, que deveria servir também para receber pessoas externas à família. Sampaio tem ainda atitude mais assertiva. Utiliza roupa formal e embora o corpo esteja ligeiramente inclinado, o olhar está direcionado para a câmera, encarando assim o observador da cena. Os braços estendidos sobre a cadeira e mesa indicam ainda que o homem dominava o espaço, reiterando a apropriação do lugar. A utilização no título da palavra "retrato" é sugestiva do que Sampaio considerava como sendo este gênero. Trata-se da concepção do período de que eram as imagens que evidenciavam aspectos da fisionomia do indivíduo e, ao mesmo tempo, marcavam determinada importância e lugar social.

Vale ressaltar que sob o ponto de vista técnico, mesa e papéis constituíam apoios, sendo verdadeiros rebatedores para a iluminação proveniente do ambiente 
externo. Recurso muito importante quando se tratava de fotografias em interiores. Tal preocupação em utilizar recursos materiais disponíveis para a iluminação terá como resultado a constituição de ambientes mais intimistas com sombras, regiões com altos e baixos contrastes, que Sampaio irá explorar amplamente em seus registros.

É o que ocorre nas fotografias de auto-retratos em que o uso da iluminação com mais contraste irá pontuar a segunda identidade de Alberto de Sampaio, como fotógrafo amador. Embora sejam poucas tomadas com tais características (3 fotografias), elas tem alta relevância para o acervo, como a cena em que Sampaio aparece de frente a um espelho (Fig. 75). Nesse caso, o fundo com o móvel conta pouco e está fora de foco. O corpo não foi tomado por inteiro, somente em parte, no espaço que ficou visível no espelho acima do joelho. A postura corporal também seria diferenciada e, por certo, muito mais relaxada. Sampaio tem um dos braços apoiados na cintura e outro na ação de puxar a alavanca do obturador da câmera, o que indica certo descompromisso e vínculo direto com a ação de produzir fotografias. A própria vestimenta é mais despojada, ou mesmo confortável, importante para aqueles que trabalhavam de pé, seja para fazer as tomadas, seja na atividade laboratorial.

Em relação às áreas como copa, lavabo e quartos, regiões interditas à visitação, em que somente aqueles que pertenciam ao núcleo adentravam, não há registros enquanto tema principal. Em poucas situações os espaços são registrados com pessoas (cinco fotografias). Conforme ressalta Jeffrey Needell (1998: 180), ali o uso do espaço e decoração seriam mais descompromissados, sem tantos requintes e normas de etiqueta importadas. Até porque a necessidade de representar publicamente o "status da família" teria menor relevância. Da mesma forma, como apresentado anteriormente, as imagens reiteram também aqui o papel da mulher como aquela que cuida dos filhos e o homem 
aparece numa mediação com o espaço público, num indício de sua atividade fora do ambiente doméstico.

É preciso destacar, por último, que nas fazendas de Santa Alda e Chacrinha há menor produção de fotografias que registrem a vida doméstica (33 imagens). Na série, quando as cenas são do grupo de família em espaços internos, destacam-se muito mais outros ramos da parentela, documentados em salas de jantar e estar como os sogros, cunhados e sobrinhos. A área contígua à residência podia servir de cenário para os retratos, mas de maneira diferenciada, pois as fazendas eram um espaço de lazer para a família e, por isso, as próprias fotografias iram, em geral, marcar essa diferença de uso.

\section{Materiais e Linguagem}

Primeiramente trabalhamos com o espaço e comportamento nos ambientes. No conjunto de imagens apresentadas, nota-se que não há registros dos ritos da vida familiar como cenas de aniversários, casamentos ou nascimentos de crianças, reconhecidas como o principal interesse dos álbuns de família. No período aqui analisado, fica evidente que, apesar de haver longa dedicação de Alberto de Sampaio em catalogar e nomear as fotografias, essa não é uma obra memorialística. A perspectiva de mudança temporal é quase inexistente, está apenas em alguns casos que constituem exceções dentro do acervo. A maioria são imagens cotidianas, que não apresentam nada de excepcional ou relevante para que merecesse ser documentada. Há, por certo, continuidade mas sem transformação, numa perspectiva propriamente diacrônica.

Nas fotografias produzidas geralmente por profissionais, no século XIX, encontramos relação, em parte semelhante, com esse uso da imagem. Não havia costume, por exemplo, de fotografias dos ritos religiosos praticados pelo grupo familiar. 
A exceção, como aponta Mariana Muaze (2008: 184), eram a primeira comunhão e a formatura, momentos em que as classes mais abastadas iam ao estúdio de um profissional. Essas fotografias, porém, traziam apenas as marcas simbólicas dos eventos, não sendo realizadas no momento da comemoração. Isso se torna mais evidente no hábito já difundido entre as elites de realizar fotografias em estúdios antes e depois da cerimônia do casamento. Mas apesar da presença restrita no âmbito do retrato, sabemos que todas essas festas não eram mais exclusivas de pequenos grupos e tinham sua importância social, conforme a autora destaca. No século XIX, os ritos da vida religiosa se tornaram representações públicas, por meio do qual os membros da instituição familiar de elite reiteravam seus laços e se diferenciavam assim das demais classes.

Tal distanciamento entre a fotografia e o evento familiar se deve, certamente, às dificuldades técnicas de utilização de equipamentos em ambientes fechados, que não dispunham de condições de iluminação apropriadas. Mas o problema principal reside na função da fotografia nesse momento. Como muito bem apontou Ana Maria Mauad (2008: 131), a imagem que entrava em circulação atuava sempre como forma de "pertencimento e de reconhecimento do lugar social", deveria, portanto, marcar as posições dos indivíduos de maneira apenas genérica, daí haver essa relação tímida com os eventos em si, mesmo com os que já tinham relevância significativa.

Quando o amador começa, ele mesmo, a documentar a vida familiar se esperaria que "naturalmente" esses ritos religiosos ou outras comemorações constituíssem tema para os registros. No acervo Alberto de Sampaio, porém, observamos que a seleção era de outra ordem e as questões principais ligadas à produção fotografica não estariam associadas ao cotidiano das festas e comemorações, mas, de maneira preponderante, aos 
problemas da disposição dos materiais, da encenação e do humor, os quais tiveram papel distinto e relevante entre os amadores do período.

\section{O fundo}

O fotógrafo amador utilizava recursos no espaço doméstico por meio dos quais se fazia mediação com o universo profissional. Já nas primeiras imagens realizadas no século XIX, por Alberto de Sampaio, encontramos esses elementos como o uso do fundo neutro. Uma cena típica desta série é "Retrato de Nanhã" de 1890 (Fig. 76) prima do fotógrafo - em que foi disponibilizado como fundo neutro, um lençol estendido em algum ambiente do interior doméstico. O uso da iluminação, a postura do corpo ligeiramente inclinado em relação à câmera e os gestos contidos dialogam com o modelo vigente dos retratos de estúdio profissional. Até porque, como já ressaltamos, no processo de revelação da fotografia, esses sinais do ambiente seriam retirados, ficando apenas a referência ao fundo infinito (Fig. 76.1). Valorizava-se então a fisionomia, pois Sampaio geralmente fazia grandes ampliações dos retratos, maiores do que os próprios negativos de vidro.

O uso do fundo neutro era muito utilizado também no quintal, onde Sampaio podia fazer fotografias de amigos em visita à residência, como aparece num registro bastante representativo deste conjunto de imagens. Trata-se do casal "Eduardo Rudge ${ }^{81}$ e Senhora" de 1910 (Fig. 77). Nesse caso, a colcha foi pendurada no varal de roupas, sendo disposta de maneira não muito ordenada, valorizando-se a própria existência das dobras no tecido. As crianças da família também eram registradas utilizando-se, em alguns casos, apenas um lençol branco com em "Luluta" de 1910 (Fig. 64).

\footnotetext{
${ }^{81}$ Eduardo Rudge era também sócio do Club dos Diários.
} 
Mas Sampaio construiu um painel em madeira coberto com tecido neutro, especificamente para realizar esse tipo de tomada. Usado apenas no quintal, o fundo aparecia em tomadas como a do menino negro (Fig. 78) - possivelmente filho de um empregado da residência em Petrópolis - em que observamos o painel destacado num entorno bastante simples composto pela cerca em madeira e vegetação, situada na parte de traz daquela residência. Nesse caso, a composição se destaca pelo uso da iluminação em alto contraste. As sombras projetadas no chão indicam a utilização de um segundo painel, um tipo de rebatedor que gerou o destaque na silhueta, circunstância que só poderia ser explorada no espaço do quintal. Os contrastes se evidenciam também em relação à postura da criança que segue o padrão dos estúdios: por um lado, o corpo semi-rotacionado e o rosto em perfil; por outro, gestos estudados se contrapondo ao cenário simples e aos pés descalços. Nem sempre, porém, era possível eliminar sinais do ambiente, conforme observamos na cópia revelada desta imagem (Fig. 78.1). Aqui um pequeno trecho da vegetação ficou aparente na parte direita da cena, por certo, intencionalmente, pois, nesse caso, seria possível eliminar qualquer sinal do espaço exterior. Como também se evidencia em outras situações, o fundo neutro era utilizado de maneira flexível; as convenções, portanto, podiam ser adaptadas às circunstâncias e interesses pontuais.

Desta maneira, embora a fotografia com fundos neutros em ambientes domésticos constituísse referência aos elementos encontrados na produção profissional, não podemos considerá-la apenas como imitação de um modelo. Circulavam nas publicações destinadas aos fotógrafos, escritas geralmente por amadores, sugestões próprias à utilização desses painéis. É preciso considerar que já nos primeiros grupos formados por amadores havia forte crítica à fotografia de estúdio, uma vez que tais segmentos buscavam se diferenciar do padrão corrente. Como já destacamos, desde o 
período em que a prática era exclusiva das mais altas classes sociais, fomentava-se a crítica aos exageros encontrados nos estúdios (Seiberling, 1987: 18).

Na última década do século XIX, momento de extrema valorização da fotografia como atividade artística, tal crítica teria maior repercussão ainda, pois o circuito da fotografia amadora havia-se ampliado e as discussões não ficavam restritas aos manuais técnicos. Integravam agora quase todas as revistas ilustradas, como vimos, que publicavam matérias sobre fotografia. A The Graphic, por exemplo, traz num texto de 1896, escrito por T. C. Hepworth ${ }^{82}$, comentários muito representativos sobre a problemática. Duas exposições importantes haviam ocorrido em Londres naquele ano, e Hepworth irá fazer restrições veementes ao que se difundia no estúdio profissional:

\begin{abstract}
"The thoughtful visitor to either of these interesting displays must readily see that a great change, and a change for the better, has come over a photographic method of picture making. It is not simply a change of fashion but a successful endeavour to get something more worthy the name of Art into the four sides of pictures, and to step out of the well beaten path indicated by the old style of cheap portrait. As to posing the figure there was nothing of the kind attempted, beyond putting the head of the sitter into a clamp and rest and allowing the hand to hang over a dwarf pillar robbed of its capital for the express purpose. Now all this is changed, and the skilful photographer makes quite a study of the arrangement both of figure and drapery. [...] The artificial aids to the studio work, coming under the head "accessories", which comprised imitation cabinets, writing tables, \&.c, of aggressively ornate pattern, have altogether disappeared, and sober shadows skilfully managed take their place" ("The two photographic exhibitions". The Graphic, October 3, 1896: 434).
\end{abstract}

\footnotetext{
${ }^{82}$ T. C. Hepworth tinha coluna na The Graphic, "Amateur Photography", e escreveu vários livros, dentre eles o The Book of Lanterne, being a pratical guide to the working of the optical (or Magic Lantern). London: Wyman \& Sons, 1888. Foi também inventor de equipamentos ligados à fotografia e ao cinema (Nead, 2004). Seu filho, Cecil Hepworth (1874-1953), foi pioneiro na indústria cinematográfica britânica, produzindo filmes de 1898 até os anos 1920. Teve sua própria companhia, a Hepworth Manufacturing Company, e foi autor dos livros Animated Photography e The ABC of the Cinematograph em 1897. Disponível em: http://www.victorian-cinema.net/hepworth.htm.
} 
Nestas mostras anuais da Royal Photographic Society e do Linked Ring Brotherhood $^{83}$, evidencia-se nas imagens expostas, o abandono do cenário em benefício da exploração plástica do corpo, uma concepção estética já antiga, que se opunha à fotografia de amplo consumo, mas que iria ter espaço de difusão nesse cenário formado por publicações, clubes e recursos técnicos. Nos países europeus e EUA, os amadores não eram mais apenas os antigos savants que dispunham de estrutura e conhecimentos mais aprimorados que os profissionais. Havia assim todo um grupo de praticantes provenientes das classes médias urbanas, que precisavam utilizar elementos disponíveis em seus ambientes para fazer retratos, sendo necessário improvisar para o desempenho da atividade. É nesse contexto que os artigos da The Graphic (3/4/1897: 380) começam também a destacar essas questões, como ocorreu no segundo "Amateur Photographic Competition", organizado pela revista:

“[...] The amateur photographer when he attempts portraiture, is generally tempted to step out of his conventional groove, and to try experiments in lighting his subject, for which his professional brethren have little inclination. It is, perhaps, fortunate for his purpose that he does not possess a glass studio where light is ample in all directions. He is forced to utilize ordinary dwelling rooms, and to get what light he can from one window, using reflecting surfaces, to secure the necessary half-tones of the shady side of his models $[\ldots]$ "..

O problema da composição, luz, indumentária e articulação de volumes no uso improvisado dos materiais disponíveis no ambiente doméstico, seria validado de maneira positiva. Os próprios manuais começam a dar espaço para os recursos domésticos que necessitavam ser disponibilizados. Um dos mais populares era, o já citado, Tratado elementar de photographia pratica de Gaston Niewenglowski, aqui publicado pela Livraria Garnier em 1907.

\footnotetext{
${ }^{83}$ O Linked Ring organizou o Photographic Salon desde 1893, um ano depois da fundação do grupo. As mostras ocorreram até o início do século XX. Participavam da exposição membros do clube como Henry Peach Robinson, Robert Demachy e Constant Puyo (também do Photo-Club de Paris) e Alfred Stiegliz.
} 
Por isso, é possível afirmar que uso o improvisado de materiais servia também, para certos amadores que criticavam o artificialismo das imagens produzidas em estúdio, como uma forma de se diferenciar dos profissionais. É nesse contexto que Eunápio Deiró, em seu artigo publicado na Kosmos (10/1904, anno I, n. 10), menciona o problema em função da apreciação estética e destaca que "conhece-se o horror habitual dos retratistas pelos panos sem fenda, sem dobras". Fazendo alusão ao livro de memórias de Julia Margareth Cameron, fotógrafa amadora já bastante conhecida e respeitada na Inglaterra (Annals of my Glass House, publicado pela primeira vez em Londres, em 1889), Deiró lembra um episódio em que ela afirma preferir para o retrato uma "toillete bem amarrotada".

Alberto de Sampaio utiliza esses recursos para fazer suas imagens e mesmo seus fundos neutros deixam, em algumas situações, transparecer o que não era considerado como um defeito, os tecidos amarrotados. Com isso, valorizava-se muito mais a expressão facial daquele que estava sendo registrado, como na imagem de Gustav Guilman (Fig. 79). Este amigo de Alberto de Sampaio era um engenheiro inglês que trabalhava na Companhia Victória Minas e foi também fotógrafo amador. Talvez, seja por isso que Sampaio tenha feito tantos retratos de Guilman (seis ao total) com grande apuro estético. Afinal, eram imagens que, certamente, seriam trocadas entre dois aficionados pela fotografia. Nesse caso, houve atenção especial para a iluminação com contrastes que acentuam a expressão fisionômica de Guillman - com as rugas aparentes na face - e do fundo em tecido.

Pode-se afirmar, com segurança, que isso não era uma característica apenas de Alberto de Sampaio. O caso estudado por Eduardo Covas (2005) sobre o fotógrafo amador Francisco Brandão, aponta na mesma direção. O farmacêutico e fotógrafo amador, nascido em Portugal, que imigra para a cidade de Piracaia, no interior de São 
Paulo, na década de 1890. Conforme aponta o autor, Brandão já tinha excelentes condições financeiras em Portugal e, por isso, se insere naquele perfil "amador" de fins do século XIX, proveniente de classes médias urbanas, sendo também um leitor de manuais.

A produção fotográfica de Brandão é de particular interesse para nosso estudo. Há certamente algumas diferenças importantes em suas imagens, havendo menor preocupação no tratamento estético, como indica o próprio Covas (2005), ao fazer diferenciação entre os registros de Brandão e os do outro fotógrafo amador de Campinas, Austero Penteado. Porém, percebemos nos retratos de membros de sua família no ambiente doméstico, o uso de fundos neutros, como lençóis, de maneira muito semelhante às imagens de Sampaio (Figs. 80; 81). Aqui observamos quase um padrão mais amplo estabelecido entre os amadores com a produção de retratos.

Os sinais de improviso com o uso dos fundos com lençóis, contudo, passavam a ter valorização estética positiva não somente para o público aficionado. Até mesmo alguns profissionais da fotografia iriam fazer seus registros com esses recursos de caráter doméstico. Nas imagens realizadas por Augusto Malta, de personalidades do campo político e artístico, observamos prática semelhante como no registro de Joaquim Nabuco, realizado em 1906, ou do Marechal Hermes da Fonseca, de 1911, em que há tecidos amarrotados como fundo e a total ausência dos recursos formais encontrados nos estúdios do período.

\section{Encenação}

A questão do uso improvisado de materiais, pensada como uma prática, estaria de diversas formas nos manuais e revistas ilustradas do período. O espaço doméstico, no entanto, se tornaria palco para outras mudanças condicionadas aos vínculos que a 
fotografia começava a estabelecer com a representação da família. Nesse âmbito, a segunda questão a ser ressaltada é a encenação. No acervo Sampaio, em grande parte das fotografias é como se a família estivesse sempre desempenhando alguns papéis, tal como numa cena teatral.

O interior doméstico, como ressaltamos, era o lugar apropriado para que esses papéis fossem diferenciados segundo gênero, faixa etária e expectativas sociais. A imagem feminina estava associada aos cuidados com filhos e a casa, e a masculina ao universo do trabalho. Duas fotografias que complementam o que foi dito sobre o espaço e os atores, marcam oposições nítidas. Em “Cecília dando comida a Dudu” de 1910 (Fig. 82) a mulher aparece na copa no ato de alimentar o filho, num espaço que só era freqüentado pela própria família. O fundo e, mesmo, o primeiro plano, com os pratos na mesa desfocados, demonstra haver menor preocupação em demarcar objetos naquele lugar. A mesa também servia como rebatedor para a iluminação proveniente da janela. Já em "Meu retrato no escriptorio" de 1907 (Fig. 83), há maior nitidez nos livros, papéis carimbo, porta-retratos e máquina de escrever. Todos esses materiais desempenham funções simbólicas mais amplas, fazendo alusão ao exercício das atividades masculinas fora da casa. Há também alto contraste que valoriza a introspecção, numa alusão ao universo interior mobilizado na atividade intelectual ali desempenhada. No entanto, é preciso ressaltar que em ambos os casos trata-se de poses altamente estudadas, pois as condições de iluminação precárias do interior inviabilizariam instantâneos, como sugerem as cenas.

Essas fotografias trazem, então, alto grau de encenação, um problema relevante que merece ser destacado, uma vez que tem seus fundamentos principais estabelecidos na cultura fotográfica do século XIX. Miles Orwell (1989: 85) identificou alguns componentes desse quadro como a dicotomia entre artifício e mímesis presente na 
prática fotográfica desse período nos mais diferentes campos de atuação, seja nos retratos de estúdio, nas imagens produzidas em expedições científicas, nas estereoscopias ou em determinada produção amadora. A idéia de representação estaria tão fortemente incorporada à fotografia, que o autor fala em "types of reality". O mais importante era a "verdade da imitação", aquilo que podia convencer e não o fato "real". Figura expressiva nesse contexto foi Henry Peach Robinson que, como vimos, utilizava até mesmo vários negativos para compor uma única fotografia, numa manipulação artificial que permitia construir cenas inventadas de maneira altamente plausível.

No momento em que tais discussões e oposições ganhavam força, haveria desdobramentos do problema da encenação, na produção amadora. Para esse grupo a residência constituía o espaço privilegiado para "photographar os assumptos de interior nos proprios interiores" pois ali “o efeito será sempre justo, senão harmonioso...”, referência à Constant Puyo no já citado Tratado manual de photographia pratica (1907) de Gaston Niewengloswski. Nesse popular manual, como em tantos outros do período, sugeriam-se pequenas representações segundo o gênero. Havia determinadas ações interrompidas, numa alusão ao instantâneo, como mulheres na atividade de costura, tendo as ferramentas do trabalho doméstico em evidência. Tal imagem típica feminina estava inclusive nas exposições dos amadores. Joaquim Barrozo Netto, na segunda exposição do Photo-Club do Rio de Janeiro, realizada em 1905, foi premiado com a cena denominada "Costurando", em que uma mulher aparece debruçada sobre uma mesa com tesoura, papel e tecido, em atitude também introspectiva, relacionada com suas funções na residência.

Outra dimensão do problema da encenação, num grau até mesmo elevado, quase de rompimento com a idéia de artificialismo, seria evidenciada nas populares fotografias que continham algum truque, divulgadas em revistas ilustradas. A partir de 1900, por 
exemplo, a Lectures pour tous, nos concursos organizados para fotógrafos amadores, incluía gêneros e temáticas relacionadas à fotografia segundo a concepção artística do período como "paysage", "portrait" e "scène animée". Além disso, havia a "composition fantaististe ou comique", seção em que se valorizava a imaginação dos autores, a capacidade de inventar situações cômicas utilizando, na maior parte das vezes, "truques" como os franceses denominavam as "supercheries" com dupla exposição. Nos concursos, havia sempre cenas em que as pessoas eram "replicadas", aparecendo em atitudes diferentes na mesma imagem.

Aqui havia uso auto-referente da representação de caráter ilusório, que teria como conseqüência abrir espaço para o questionamento dos próprios limites da fotografia. Ainda na Lectures pour tous, num artigo sobre as "supercheries photographiques", dizia-se que:

"Pendant longtemps il a été admis que le témoignage de la photographie était audessus de toute contestation, échappait à toute discussion. Le mot lui-même de photographie était synonyme d'exactitude fidèle et de vérité idéniable. Comment admettre qu'un prócédé de reproduction reproduisit ce qui n'existait pas ? Or, ce qui, il y a peu de temps encore, eut semblé absurde est ajourd'hui un fait acquis » (1901: 900, grifo original).

Tal concepção não ficava restrita às revistas estrangeiras. No Brasil, na Leitura para todos, que seguia exatamente o modelo deste periódico francês, aparecem as primeiras matérias em português sobre o tema. Na seção “As últimas novidades na arte photographica", encontramos um longo comentário sobre o problema da verossimilhança fotográfica, à maneira da revista francesa:

"Ensinou-nos a experiência a não ligar confiança absoluta á famosa asserção de que "a photographia não mente nunca". A verdade é que a photographia é muito capaz de mentir, isto é, de produzir imagens falsas, susceptíveis, de crear no nosso espírito illusões e ideas errôneas; e se na maioria dos casos essa propriedade é utilizada apenas para o fim de divertir inocentemente, nem por 
isso em várias circunstâncias, se tem hesitado em lançar mão dela para fins malévolos e caluniosos" (12/1906: 67, anno II).

Por meio dessa categoria, a convenção aceita socialmente de que fazer fotografias era "manipular" a cena, representar um papel e inserir-se num typo, numa classe, passa a ser utilizada de maneira consciente e auto-referente, às vezes provocando também constrangimentos ${ }^{84}$. Validava-se assim o falso, a intervenção e a possibilidade do autor decompor a cena segundo critérios em que o convencimento tinha peso menor. Mas aqui cria-se também um contexto favorável ao uso da fotografia de maneira cômica, que marcasse oposições e quebrasse expectativas, conforme iremos destacar a seguir.

\section{O humor}

O espaço doméstico, nesses primeiros anos do século XX, era lugar apropriado para outra dimensão e uso da fotografia em que improviso e encenação seriam articulados, permitindo aqui ocorrerem, de fato, transgressões ao padrão corrente do retrato profissional. Trata-se do humor, o terceiro componente que iria marcar a imagem da família nesse momento.

Mas qual o sentido do humor nas fotografias? Não era certamente aquele de que fala Baudelaire (1998) como sinal da superioridade do indivíduo, mas, sobretudo, como um indicador de ruptura inesperada como mencionado por Freud ou inversão em Pirandello como muito bem indicou Elias Thomé Saliba (2002: 24; 29) a respeito do diversos sentidos do riso em nossa Belle Époque. O riso, nessa perspectiva, podia

\footnotetext{
${ }^{84}$ Vale ressaltar que tal uso da fotografia não ficava restrito aos amadores. No Brasil, há uma conhecida imagem do fotógrafo Valério Vieira, que foi premiado num concurso internacional, em 1904, na Exposição de São Luis nos EUA. Em "Os trinta Valérios", o próprio fotógrafo aparecia de diversas maneiras numa sala, exatamente tinta vezes (Cf. Kossoy, 1980: 78).
} 
também funcionar como uma forma de compensação ou revelar contrastes e ambigüidades, sendo um verdadeiro "esforço inaudito de desmascarar o real, de captar o indizível, de surpreender o engano ilusório dos gestos estáveis”.

É nesse mesmo contexto que o humor ganha espaço dentro da representação familiar, porém, uma de suas principais funções, que é a perspectiva crítica para ressaltar aspectos de valor, desaparece aqui. Na visualidade dos amadores, como está indicado na produção de Sampaio, o humor é aristocrático, simulado e gentil. Era também privilégio apenas dos homens e crianças. A mulher estava excluída, cabendo a ela apenas reafirmar seu papel dentro do ambiente doméstico. Assim, determinadas transgressões estavam associadas à questão de gênero e faixa etária.

No interior da casa o humor não estaria atrelado aos eventos da vida familiar, como festas e demais momentos de passagem. A dimensão do cotidiano na fotografia estava muito mais vinculada ao interesse pelo acontecimento banal, em que sinais de mudança temporal como o crescimento das crianças ou mesmo a reforma da casa não seriam demarcados com veemência. Havia um tipo de presença continuada e a fotografia, evidenciando poucas transformações do grupo familiar, não tinha como função relevante ser um registro de memória.

Tais aspectos estão indicados numa imagem significativa da série, “Alberto no toillete" de 1906 (Fig. 84), em que observamos o próprio fotógrafo arrumando o bigode em frente a um espelho. Todos os objetos que integram o ritual de cuidados com a aparência estão ali: toalha, escovas e bacia para água. Sampaio está de costas para a câmera, numa das poucas cenas em que aparece por inteiro no quadro fotográfico, e seu rosto só pode ser visto pelo reflexo no espelho. Mas ele segura o bigode, simulando a ação como se tivesse sendo flagrado num instantâneo. A situação é inusitada, pois espaço e atividade, que são íntimos, revelam a força normativa sobre os cuidados com o 
corpo. Então, a norma está sendo respeitada, pois para expor o corpo fora da residência é necessário ter o bigode arrumado; a imagem indica, portanto, a mediação entre o espaço privado e público e aí tem o aspecto de humor.

Não sabemos se ali era um banheiro ou área de lavabo contígua ao quarto, porém, trata-se de uma alusão a um espaço cada vez mais valorizado no interior das residências. Nesse momento, os banheiros ganhavam nova significação e, como destaca Nicolau Sevcenko (2002: 562), convertiam-se na "peça mais moderna da casa". Ali era o lugar em que se podia efetivamente desprender altas energias para os cuidados com o corpo, num momento em que as idéias de beleza, saúde e higiene convertiam-se numa verdadeira prática social. Para o autor, os banheiros revelariam “o quanto a esfera privada mantém uma estreita interdependência com as fantasias coletivas”.

O problema do humor como reforço das normas aparece também em duas fotografias em série - uma característica da produção de Alberto de Sampaio, pois encontramos outras unidades. Embora os atributos estejam aqui exacerbados pelo uso muito específico da narração, mesmo assim são registros importantes para o conjunto. Na primeira imagem (Fig. 85), Bento está sentado na cadeira de balanço com o Jornal do Commercio e um charuto na mão, na sala de estar. O espaço é bem restrito e as cortinas sobre as janelas não permitem estabelecer nenhuma comunicação com o exterior. O posicionamento do corpo da criança é bem sugestivo para a encenação: ela está com um dos pés estendidos, jornal sobre a perna - que funcionava como um rebatetor para a luz proveniente da janela - e com o charuto próximo ao nariz. A ação e objetos do entorno, portanto, eram do universo adulto, interditos para uma criança. Na segunda imagem (Fig. 86), Sampaio aparece repreendendo o filho, num puxão de orelha, e com isso, a transgressão é castigada e a ordem restaurada, desfazendo-se a ação anterior. Vale lembrar que o tempo de exposição para uma cena como essa deveria 
ser mais elevado. Eles estavam ali certamente por algum tempo, posando para a câmera disposta num tripé, e tudo indica que o instantâneo é construído e simulado. Trata-se também, nesse caso, de uma brincadeira, que revela não haver crítica em tal dimensão cômica. Ao contrário, transparece mesmo certo conservadorismo.

Tal uso da fotografia de maneira teatral não constituía, por certo, novidade. Nos cartões postais havia séries muito populares que contavam pequenas histórias e as expressões corporais dos personagens eram também evidenciadas. Compostos por várias imagens em sequiência, geralmente com efeito cômico, tais cartões acentuavam o caráter teatral das ações, como no conjunto que pertencia ao próprio Alberto de Sampaio (Figs. 87; 88; 89).

Mas o uso narrativo da fotografia no interior doméstico associado aos papéis sociais diferiria, em Sampaio, completamente no espaço do quintal. Poderia, nessa situação, ocorrer o uso de fundos neutros, como um painel de madeira que era utilizado constantemente, conforme em "John com os garnizés" e "Luluta com os garnizés", ambos de 1905. Aqui, o efeito cômico é estabelecido pelo contraste entre o retrato, que utilizava recursos que dariam maior sobriedade à cena, e as galinhas que as crianças seguram (Fig. 90; 91). Duas imagens muito valorizadas pelo fotógrafo, pois foram feitos quadros, com as fotografias ampliadas, que ficavam expostos na sala de estar, na entrada da residência (Fig. 59). Desta forma, as brincadeiras com as fotografias não ficavam restritas apenas aos olhos dos membros da família, pois encontram uma forma de exibição ampliada, mesmo que apenas para aqueles que podiam visitar o espaço doméstico.

Encenações mais livres, em que o uso expressivo do corpo seria acentuado, ocorriam também no quintal. Numa cena típica das crianças, "Álvaro e Bento lutando" de 1904 (Fig. 92), elas posam a fim de simular uma brincadeira, que é referida como 
briga pelo título dado por Sampaio. Não há, nesse caso, escolha do que seria a parte do quintal mais bem cuidada e o fundo da imagem é composto por uma área nada suntuosa da residência. Da mesma forma, em "Effeito do sol nos meninos" (Fig. 70), todos estão sentados, com o corpo desmobilizado e expressões faciais que remetem à alta exposição ao sol, uma ação que só pode ser entendida e completada pela legenda.

Embora não tenhamos exemplos para avaliar o problema do humor em outros acervos de amadores no Brasil, há um caso já estudado que reforça a possibilidade de isso não ser uma idiossincrasia de Sampaio. Trata-se do já referido acervo de Francisco Brandão, analisado por Covas (2005). Ali encontramos uma forma específica de realizar imagens de família, como a cena em que o amador é registrado em frente à farmácia junto aos seus filhos (Fig. 93). O grupo aparece sentado lendo jornal e, por isso, os papéis são homogeneizados, sem haver destaque para as diferenças hierárquicas entre

pais e filhos. É, portanto, contra as expectativas do que seria a representação convencional familiar, encontrada nas fotografias daquele período.

\section{Fotografia e jogo}

O problema do humor está relacionado com questões mais amplas integrantes do quadro cultural desses primeiros anos do século XX. Havia acentuada mudança de usos e significados da fotografia, seja pelos novos equipamentos, seja pelos meios de impressão que permitiam a difusão das imagens em revistas, jornais ou cartões postais. Por isso, muitas das propagandas divulgadas por meio de fotografias iriam associar a câmera à idéia de diversão, abrindo-se uma brecha para outros tipos de apropriação da imagem.

Os estudos sobre fotografia no Brasil não demarcam essa problemática especificamente, sejam os que estão voltados para a produção profissional ou amadora. 
Mas há uma bibliografia estrangeira importante, já sedimentada, que aponta essas questões como sendo centrais para os fotógrafos amadores. Para Nancy West (2000: 38), como vimos, a fotografia, nas propagandas da Kodak, era uma "form of play", jogo ou diversão. Situação modificada apenas a partir de 1915, quando, nos reclames, começam a ser evocadas as idéias de família, nostalgia e memória.

No período em causa, em que o próprio Sampaio se dedica a fazer catalogação de sua produção, a Kodak lança a câmera Brownie (1900), direcionada para as crianças $^{85}$, custando apenas 1 dólar. Por isso, muitos historiadores apontam a Brownie como tendo ocasionado o maior impacto sobre a prática da fotografia amadora e não o Modelo n.1, lançado em 1888, que custava 25 dólares, objeto de consumo das classes médias. Ao produzir um equipamento de uso exclusivo de crianças, a Kodak passava assim, ainda mais, a legitimar a "photography as a real play, children thus constituting the only social group whose status in modern culture rests on play's associations with innoccence, spontaneity, imagination, and freedom” (Ibid., 2000: 75).

No Brasil, as revistas nacionais não divulgavam propagandas das câmeras nesse momento. Mas nos periódicos estrangeiros, era possível encontrar diversos reclames de todos os equipamentos que circulavam por aqui. A The Graphic merece destaque pela própria difusão, uma vez que integrava, com vimos, quase todas as bibliotecas públicas do Rio de Janeiro, das escolas superiores e também estava em acervos particulares. Nesta revista encontramos propagandas da Brownie em 1909, com o slogan "Let the... children Kodak", em que uma menina segura a câmera numa cena doméstica, que seria convertida em fotografia (Fig. 94).

Embora a câmera Brownie não fizesse parte do acervo Sampaio - possivelmente porque era um equipamento muito simplificado - determinado uso da fotografia

\footnotetext{
${ }^{85}$ Não havia só a câmera mas todo um sistema próprio complementar para o uso do equipamento infantil, como papéis fotográficos, tanques de revelação dos negativos, enfim, materiais que podiam ser adquiridos num único kit.
} 
sugerido em suas propagandas estaria presente na produção desse amador. Ele faz, inclusive, duas fotografias no quintal, em que a encenação e o humor são estabelecidos seguindo os códigos da atuação infantil no espaço doméstico com o uso das câmeras fotográficas. Na primeira cena (Fig. 95), o menino simula o papel do fotógrafo e faz gestos para chamar a atenção daquele que seria fotografado. Numa alusão a um número de mágica, ele segura um lenço branco numa das mãos e, na outra, está com o extensor do mecanismo, o obturador da câmera Kodak. A segunda fotografia (Fig. 96) seria o momento exato de realização da tomada e, curiosamente, as duas crianças fazem gestos com o corpo, indicando assim um tipo de contentamento, alegria e espontaneidade. Fotografar era se divertir; evidenciava-se, portanto, em registros como esse, o sentido atribuído ao "play", associado mais fortemente à produção da fotografia de família, representada pelos amadores.

Tais questões não eram certamente exclusividade das propagandas da Kodak. As revistas ilustradas desempenhariam papel também central nesse contexto, dando espaço para outro tipo de registro que iria fugir das convenções, numa associação de experimentação e imaginação. É o que ocorria na revista Lectures pour tous que, como mencionamos, promovia concursos para os fotógrafos amadores, em que se valorizavam as duplas exposições para a composição cênica. Mas para Alberto de Sampaio o uso cômico da fotografia aconteceria mais fortemente na encenação. Em, por exemplo, "Phantasma" (Fig. 97) de 1905 ele faz apenas uma sugestão técnica, pela presença da criança com o lençol branco que parece flutuar naquele espaço. Não era o que ocorria, pelo que pudemos perceber, na produção de Francisco Brandão, cujas cenas com dupla exposição seriam realizadas com a própria figura do amador. Numa das fotografias (Fig. 98) apresentadas por Eduardo Alves Covas (2005: 76) Brandão aparece cinco vezes na mesma tomada, com roupas diferentes representando vários personagens. Até 
mesmo o fundo neutro escuro foi utilizado como um recurso, não apenas para anular o espaço, mas para auxiliar a ilusão de que a cena "real" não estava ocorrendo naquele ambiente.

Sampaio, diferentemente, se dedicará a acentuar o efeito cenográfico sem utilizar tantos recursos do trabalho no laboratório. Daí a importância que ele confere ao carnaval, pois nesse momento particular o fotógrafo podia registrar as crianças fantasiadas, numa forte carga de encenação e humor como na cena em que aparecem seus quatro filhos fantasiados de bebês (Fig. 99). Essa é uma tomada típica desse conjunto: são sempre crianças que se comportam gestualmente de acordo com a fantasia usada e o quintal serve como cenário, sendo escolhidas áreas aleatórias desse espaço para a representação.

Os registros de carnaval ocorreram entre os anos de 1905-7, o período de maior atividade do fotógrafo e também de alta produção no ambiente doméstico. Trata-se, ainda, de uma das raras referências a um evento, por assim dizer, que Sampaio fotografa e ao qual confere importância. Vale destacar, porém, que não há nada que documente a festa em si, os lugares que sediavam os bailes, certamente comuns nesse momento na cidade, para onde as crianças seguiam com suas roupas especiais. Desta forma, o espaço desse tipo de cena seria exclusivamente o quintal.

Tais questões, entretanto, tiveram, de alguma forma, suas possibilidades abertas ainda no século XIX. Foi em alguns clubes de amadores, sobretudo europeus, que se desenvolveria também esse uso "recreacional" da fotografia. Eram aqueles que não estavam voltados exclusivamente para a problemática estética, que não organizavam "Salons", e uniam interesse científico ao exercício mais descompromissado das excursões fotográficas (Poivert, 2001: 19). Aí se propagaria a prática do instantâneo e alguns desses amadores iriam ter participação em pesquisas e descobertas como foi o 
caso, do já referido, Albert Londe. O registro do corpo em movimento, que se tornou num clichê amador, seria um dos meios de consolidação do interesse pelo instantâneo (Gunning, 2006: 89).

Mas a prática exclusiva de pequenos grupos da década de 1880 foi incorporada nos periódicos ilustrados, em propagandas de equipamentos produzidos para os próprios amadores. Outros fabricantes, além da Kodak, desenvolveram suas estratégias para atrair o consumidor, como a câmera de fabricação alemã Goertz-Anchutz. Em seus reclames na The Graphic, por exemplo, destacava-se apenas a idéia de movimento; e para acentuar esse dinamismo, nunca repetiam a mesma cena (Figs. 100). Assim, o consumidor da revista entrava em contato com centenas de fotografias, ao longo dos anos, de pessoas e animais saltando no ar. Essa ação sucessiva, que podia ser congelada com equipamentos bastante simplificados, validava de uma maneira diferente a associação livre da fotografia como diversão. Um corpo em saltos contínuos, e que não atendia mais apenas ao interesse de pesquisadores como Muybridge e Marey, conhecidos no período por desenvolverem equipamentos próprios para atender às pesquisas sobre a fisiologia do movimento.

Alberto de Sampaio faria suas versões desse tipo de registro, embora em termos quantitativos seja pouco expressivo (5 fotografias). Vale observar que foi apenas nessa circunstância que ele utilizou equipamentos mais simples, com negativos de celulóide, no espaço doméstico (todas as demais imagens eram produzidas com câmeras de grande formato e negativos de vidro que mediam 10 × $8,5 \mathrm{~cm} \mathrm{e} 13$ x $18 \mathrm{~cm}$ ). Mas, nesse conjunto, há apenas uma fotografia em que ele e seus filhos estão juntos no quintal (Fig. 101). Trata-se de um salto no ar de todo o grupo. Aqui o espaço é mais amplo, necessário para o desenvolvimento da ação. Afinal, o salto exigia esforço corporal e mobilidade. 
Cumpre ressaltar que esta foto de família, que pode ser entendida como nada convencional para a primeira década do século XX, estava de fato integrada a um amplo contexto de difusão de tecnologias. Se pensamos no cinema do período, vemos que ali se explorava a imagem do corpo acrobático, muitas vezes de atores que eram verdadeiros ginastas. Era o "corpo espetáculo" que aparecia e desaparecia na tela, como bem definiu Antoine de Baecque (2008: 481), corrente no cinema da Belle Époque e, no nosso caso, também de alguma forma replicado na produção amadora de fotografias.

Nesse contexto, o que permitia reforçar o sentimento de coesão do grupo familiar deixa de estar reduzido à troca de fotografias, que já atuavam como meio de demonstração dos elos afetivos, principalmente pelo hábito muito difundido de fazer dedicatórias no verso das imagens. O que temos a partir de então é que o próprio ato de produzir fotografias tal como jogo e diversão, torna-se sinal de uma diferente relação entre os membros da família, passando a desempenhar algum papel para o sentimento de pertença. Se pensarmos no sentido estabelecido para o jogo por Huizinga (2007: 11), o momento de produzir as fotografias seria um intervalo, não sendo, portanto, “a vida corrente" mas a "evasão da vida real". Desta forma, nos apropriando da noção de play, conforme indicado por Nancy West (2000: 38), podemos dizer que não eram os casamentos, os nascimentos dos filhos, enfim, momentos de ritual e de mudança, "os pontos culminantes da vida familiar", para usar a expressão de Bourdieu (1965: 39). Mas, ao contrário, esse momento específico, importante para ser registrado em fotografias, era a própria interação do grupo para a construção de outra representação, artificial por certo, mas conectada à demanda do "jogo", em que a infância cumpriria papel fundamental.

Nessa perspectiva, compreendendo que a fotografia era um meio de comunicação, Sampaio pode explorar até mesmo os suportes ao escrever nos negativos 
ou em superfícies dispostas no próprio cenário das tomadas. Integrava assim outros elementos para compor sentido à cena como "Este ... manda festas do... 1907" (Fig. 102). Nesse caso, talvez o fotógrafo tenha completado posteriormente a mensagem escrita, colando a fotografia no papel. Embora não saibamos o que isso representava, fica mais uma vez patente a idéia de que a fotografia desempenhava um papel nítido dentro desse grupo, como uma forma de diversão praticada conjuntamente pelos membros da família no espaço doméstico.

Daí ser possível realizar um retrato de família como "Effeito do calor em Sta. Alda” de 1911 (Figs. 103; 104), em que os membros do grupo não se apresentam mais de maneira ordenada por gênero mas se encontram dispostos numa informalidade construída, na varanda da fazenda de João Teixeira Soares. São duas cenas em seqüência, que registram pequenas diferenças de movimentação do corpo. Na tomada inicial (Fig. 103), há dois grupos: o primeiro está sentado no sofá e segundo no chão. São Alberto e Cecília, junto aos seus filhos. No segundo registro (Fig. 104) os dois meninos sentados no chão mudam a posição da cabeça e tronco, indicando o movimento quando as cenas são vistas em série. Há proximidade total das pessoas e desmobilização dos corpos num comportamento que seria certamente inaceitável em público. Temos, portanto, transgressão de um critério de conveniência, mas a culpa está referida na legenda, é o "efeito do calor", ele é o responsável por perda de controle. O problema do humor fica evidenciado então na quebra da expectativa.

Com isso a decoração do ambiente, o ornamento das roupas e sobretudo a distribuição dos personagens no espaço, conforme havia sido estabelecido nos registros padrão que representavam a família, deixam de marcar apenas o "lugar social" dos retratados. Entram em cena outros elementos na organização formal e na relação fundoobjeto destacado, os quais se referem diretamente ao evento e à percepção das pessoas 
registradas. Mas havia determinadas condições de produção para tal cena que parece, mas de fato não é, uma completa exceção à representação da família daquele período.

\section{Reiterando: a família lúdica}

O acervo de Alberto de Sampaio, como vimos, tem tendência a ignorar a transformação e seus tempos. O problema da continuidade não está demarcado em sua produção, conforme diversos autores apontam como sendo a motivação principal que caracteriza a fotografia de família. Por isso, nem mesmo nos álbuns fotográficos de Sampaio há tratamento que evidencie qualquer preocupação temporal. Até mesmo num único álbum com capa dura (contendo espaços para a inserção das imagens), destinado exclusivamente aos retratos - que tem todas as cenas importantes da série temática da família no ambiente doméstico - não encontramos tal organização.

Nesse caso, em cada página ficavam dispostas cerca de cinco fotografias. Os registros, porém, foram arranjados muito mais segundo o formato, ou seja, à medida que se encaixavam na moldura do suporte. Então, há imagens dos filhos do casal muito pequenos em diversas páginas, intercaladas por cenas em que as crianças já estavam maiores. Muitas vezes, Sampaio introduzia a mesma fotografia, fazendo diferentes enquadramentos no trabalho de laboratório - praticamente produzia outra tomada com o mesmo negativo, devido às grandes ampliações que valorizavam a expressão fisionômica. Como não existem referências às datas marcantes como aniversários, é difícil identificar variação cronológica.

Havia também um segundo conjunto de álbuns, a que já nos referimos, como sendo os oficiais da família. Eram sete exemplares em papel preto, com capa de couro que continham o total da produção de Sampaio, incluindo as séries da natureza e cidade. Aqui não é possível nem mesmo saber qual era a organização original do fotógrafo, pois 
as páginas, com furos na lateral, permitem fazer alterações constantes nas séries, como ocorre ainda hoje com os exemplares preservados pelos descendentes.

Assim, até mesmo a organização das fotografias revela a visão sincrônica na produção desse amador. Porém, como ressaltamos, isso não constituía uma particularidade de Sampaio. Havia um contexto de transformações de ordem técnica e de uso ampliado da fotografia que revalidavam além dos antigos aspectos de encenação, também outra dimensão que teria no humor e jogo elementos cruciais. É preciso ressaltar que, em alguns casos, aparecem sinais de eventos no acervo Alberto de Sampaio, mas não propriamente os excepcionais "pontos culminantes da vida familiar". O carnaval é o acontecimento mais representativo, que mereceu atenção do fotógrafo. Porém, trata-se aqui de um evento muito particular, com forte carga de encenação e que, por isso, se coaduna com as demandas do uso da fotografia como diversão.

O humor, no entanto, em todos esses casos, não tem perspectiva crítica, apenas serve para confirmar, por meio da transgressão simulada, aquilo que deveria ser a norma, reforçando assim os comportamentos considerados socialmente convenientes. Por isso, o uso da legenda para justificar o que estava fora do padrão. Embora o comportamento respeitável em público fosse validado nos retratos individuais, sobretudo nos registros de visitantes, fica evidente que o amadorismo não precisava comprometer-se com problemas como o status, os padrões homologados de comportamento, etc.

Vale ressaltar que o humor teria suas manifestações também nas menções às fotografias, que aparecem nas cartas trocadas entre os familiares. Não temos registros escritos do próprio Alberto de Sampaio, mas de Cecília há diversas referências, como a carta que ela escreve na fazenda da Chacrinha, possivelmente, depois de 1912: 
"Bom, não quero que você pense que eu estou boba, por isso vou te contar a chegada do pessoal hontem. Como você viu vieram uns 8 ou nove homens e quando começaram a me apresentar os ditos eu dei com uma cara que pela fotografia que vi de seu Castri, devia ser aquele e fiquei tremula pensando na gargalhada mas, felizmente o tal nome não foi pronunciado. [...]”.(s/data)

Assim, revalidava-se continuamente o sentido cômico na fotografia, pois esta havia se convertido numa forma de se comunicar e de manter laços familiares de maneira mais informal. Em tais circunstâncias, a fotografia amadora teria amplas possibilidades de demarcar e ser, ela mesma, um vetor de mudanças para o grupo. Mas ali havia também algumas convenções. Conforme pudemos observar, por um lado, Sampaio registra os filhos com roupas informais, próprias do ambiente doméstico e, em alguns casos, com fantasias de carnaval. Por outro lado, ele praticamente não fotografa seus filhos bebês, nem faz menção aos nascimentos, que eram praticamente anuais. A infância, de fato, só era registrada a partir do momento em que as crianças podiam representar e se comunicar com a câmera, quando as possibilidades da encenação eram mais fortes. Por isso, Sampaio valoriza a etapa da vida em que o problema do lúdico é mais importante, num momento, como destacamos, em que a própria câmera havia se convertido num brinquedo infantil. 


\section{ESPAÇO PÚBLICO (CIDADE)}

A representação da cidade no acervo Alberto de Sampaio é o menor conjunto dentro do total da produção desse amador. Há 200 fotografias. Mas apesar dessa inferior relevância em termos quantitativos em relação as demais séries, são imagens que evidenciam as continuidades e mudanças que ocorreram em sua produção, bem como as proximidades e afastamentos com o cânone difundido entre os profissionais e os próprios amadores. Também, nesse caso, nos primeiros anos, 1888-1905, com 6 registros, há maior relevo da representação da natureza na cidade; já entre 1905-1914, com 195 fotografias, ressalta-se, além disso, a dimensão urbana. Claro que não incluímos aqui, como já foi anunciado, as imagens de cidades em que elas se dissolvem na natureza - ou não existem fora de uma relação com a natureza.

Nessa série, diferentemente, temos o espaço, de maneira mais marcante, alterado pela intervenção humana. Porém, é preciso considerar que em ambos os momentos (que demarcamos na sua produção), para Sampaio, a cidade é um híbrido de natureza e artifício. Isso se acentua, em parte, pelo fato de que a cultura fotográfica artística predominante nos clubes de amadores não considerava a cidade como tema relevante. Os próprios manuais incluíam a paisagem e o retrato como sendo as duas modalidades indicadas para aqueles que desejavam ter domínio da técnica e estética, produzindo as tais imagens artísticas.

Mas porque excluem as cidades? Ou melhor, o que as cidades representavam para não merecerem reconhecimento? De fato, sabemos que a atividade amadora clubística de fins do século XIX tinha como premissa certo afastamento da tecnologia e da 
industrialização, enfim, de tudo aquilo representativo da própria modernidade, da qual a fotografia fazia parte. Antagonicamente, essas sociedades valorizavam e atribuíam prestígio à natureza como uma forma de distinção daquele que podia assim se dedicar a perceber e representar paisagens. Por isso, é corrente dizer que a cidade moderna, com todos seus atributos de valor e ainda conflitos e tensões, era colocada à parte desse movimento que, na Europa e EUA, estava associado à esfera pública burguesa (Cf. West, 2000: 37; Sternberger, 2001: 37).

Porém, ao mesmo tempo, disseminava-se uma cultura fotográfica do instantâneo em que o espaço urbano era exaltado, com a participação predominante dos profissionais. Nesse outro pólo, a fotografia era um meio material de consolidação de determinada imagem de monumentos e eventos que vinculavam cidade ao progresso e à modernidade. Os símbolos desse tipo de vivência urbana seriam divulgados em registros como, no nosso caso, de Augusto Malta, que publicava suas fotografias das comemorações ocorridas no Rio de Janeiro em revistas ilustradas como Kosmos e Renascença, na primeira década do século XX. Havia também outro tipo de fotografia muito comum no período, que eram as cenas de flagrantes de pessoas surpreendidas na Avenida Central, publicadas nas revistas mais "mundanas" como Fon Fon! e Careta.

Situado nesse contexto, dando alta importância à natureza, Alberto de Sampaio não iria conferir à cidade um tratamento particular, nem mesmo no que se refere aos títulos das fotografias e ao seu sistema de classificação. Em seu caderno de anotações as menções a Petrópolis e Rio de Janeiro estavam todas misturadas, como nas imagens referentes aos retratos e paisagem, pois, como vimos, a organização fora realizada por data e tamanho dos negativos. A única exceção é o Rio de Janeiro, que foi objeto de um único álbum organizado em 1906, no evento da inauguração do Palácio Monroe (e não está incluído neste caderno, pois não há listagem para os negativos em celulóide). Nesse 
momento, que constitui uma exceção, há utilização da câmera Kodak, que foi muito pouco empregada nos demais eixos investigados no trabalho.

O conjunto de imagens aqui analisadas, três séries, que estão associadas às principais recorrências encontradas no acervo, revelam parte dessas dicotomias, influências e mediações que Sampaio realizava em sua produção imagética. A primeira, denominada de "a cidade: entre natureza e artifício" abrange desde o predomínio da natureza (69 fotografias) até a valorização de aspectos urbanos (23 fotografias). Na segunda categoria trataremos de "vida urbana", que engloba eventos, públicos ou atividades (39 fotografias). Por último, trataremos da "família na cidade", que são as únicas imagens de familiares em espaços públicos, realizadas numa viagem à Europa, em 1913 (38 fotografias).

\section{A cidade: entre natureza e artifício}

Nesses registros há um aspecto de hibridação, diferentemente do que ocorreu na "cidade imersa" que analisamos anteriormente, na primeira parte deste capítulo. Lá trata-se do espaço urbano dominado, invadido pela natureza e aqui, diferentemente, a cidade é um artefato com seus elementos constituintes como ruas, casas, postes e equipamentos, mas estando num contexto, por assim dizer, "natural".

A produção do século XIX é escassa, há apenas uma fotografia, realizada na rua onde Sampaio morava, a "Rua de Souza Franco", em 1893 (Fig. 105). Apesar de haver uma única imagem, trata-se de um registro bastante representativo, pois revela como numa síntese, em alto grau, o caráter de hibridismo presente na série. Temos a casa situada na parte esquerda do quadro e o jardim, ambos expressando alto grau de intervenção humana. Depois há o gradil e a calçada que separam o interior doméstico do espaço público. O fotógrafo está posicionado na rua, mas é de terra batida (meio 
natureza, meio artifício), e ocupa todo o primeiro plano da tomada. Por último, à direita vêm as árvores e morros, enfim, a natureza livre. Com todas essas polaridades (que não se excluem), é possível identificar uma sequência de gradações entre o espaço interno e externo. A imagem, portanto, aproxima dois conceitos opostos, sendo tal como um oxímoro, um verdadeiro "artefato natural".

A valorização da natureza, constante na produção de Sampaio, aparece também na fotografia tirada da "Rua Marechal Deodoro" em 1907 (Fig. 106), logradouro que ficava próximo à residência do amador, no caminho de acesso ao centro da cidade. A natureza, nesse caso, é mais organizada ainda, resultado de intervenção no espaço, com árvores em série separadas também por terra batida.

Mas a cidade foi registrada no processo de virar artefato, que é evidenciado em “Compressor de Macadam” de 1905 (Fig. 107). Aqui aparece o próprio equipamento que urbaniza a rua, o qual continha um rolo para comprimir uma mistura de brita, de diversos tamanhos, a fim de uniformizar a pavimentação. Vale mencionar que a imagem foi realizada numa área muito próxima à residência de Sampaio; o cenário, no entanto, é precariamente urbanizado, embora a obra seja um indício da modernização. Uma fotografia muito sintomática porque revela, mais uma vez, a preferência por registrar o espaço com menor indício de intervenção humana. Afinal, essa obra se estendeu por todo o centro da cidade, tendo sido bastante comentada nos jornais. Sampaio, porém, nem mesmo numa circunstância como esta se detém em áreas que evidenciem dimensões do espaço urbanizado que Petrópolis oferecia aos seus veranistas e moradores.

A mesma circunstância está presente em “Automóvel nas Duchas” (Fig. 108), de 1914, em que aparece o carro Delaunay, de propriedade de Sampaio, num bairro 
denominado Duchas ${ }^{86}$ porque ali ficava a casa (do lado direito) onde funcionava uma estação hidroterápica, que foi muito utilizada também pela família imperial. Tal residência está em detalhe, envolvida pela natureza, e o poste de iluminação complementa a composição, com a vegetação ao fundo, de tal forma que parece ser também uma árvore. A cena é quebrada apenas pela introdução da máquina, o automóvel, que está vazio sem o condutor, acentuando ainda mais a pretensão de "naturalizar" o artifício. Dentro desse quadro, há outras duas fotografias em seqüência, de 1906, que registram o cunhado de Alberto de Sampaio, Lico, como era chamado Frederico Teixeira Soares, sentado numa caleche (uma carruagem de luxo) na própria rua Souza Franco. Em tal cena, a "zona doméstica", a rua em que tanto Sampaio como seu cunhado residiam, também acentuava o espaço como hibridização, em que natureza e artefato se apresentavam a partir de zonas de transição.

Mantendo semelhante percepção, Sampaio irá registrar as demais cidades visitadas no Brasil como Ouro Preto, Mariana, Além Paraíba, Três Rios, etc. Porém, são todas regiões do interior, áreas históricas ou de fazendas em que os sinais de modernização do espaço urbano eram incipientes. Poderíamos então supor que nestas regiões havia predomínio da natureza, não havendo assim uma particularidade do olhar de Sampaio nas fotografias em que as construções dividem espaço com a vegetação. Mas a imagem em formato panorâmico (composta por duas fotografias em sequência) de "Bello Horizonte" (Fig. 109), realizada em 1910, evidencia que esse amador privilegiava de maneira consciente os elementos "naturais" na cidade. Como se sabe, essa capital havia sido projetada no século XIX seguindo "parâmetros haussmanianos" e figurava ao lado do Rio de Janeiro em exposições organizadas para mostrar o Brasil moderno, tanto aqui

\footnotetext{
${ }^{86}$ O Imperial Estabelecimento Hidroterápico (complexo de vários chalés) foi concluído em fins da década de 1870. Era de propriedade do francês Antoine Court. Dispunha de piscinas, tanques e duchas de água quente e fria, alimentadas por nascente própria, além de salas de repouso. Podia atender até 50 pessoas por hora, sendo divido em alas masculina e feminina (Dunlop, 1985: 70-75).
} 
como no exterior, conforme ressalta Maria Elisa Borges Linhares (2008: 107). Sampaio, no entanto, ali representa algo próximo à sua Petrópolis, tendo, no primeiro plano, a vegetação desordenada e a rua de terra. A cidade com suas características de artefato aparece somente ao fundo, onde podemos notar a grande extensão da via projetada, retilínea, que favorecia a perspectiva, com árvores regularmente ordenadas e ainda grandes edifícios. Os sinais de modernização ficavam então no último plano, pois o amador ressaltaria aqui primordialmente a natureza.

Trata-se, portanto, de uma pré-disposição que se revela na seleção realizada por Sampaio. Certamente, devido a Petrópolis ser a cidade onde ele residia e, ao mesmo tempo, se empenhava nos circuitos clubísticos por promover a vida social aproximada da capital do país, será também o local que expressará de maneira mais veemente esse espaço de oposições. Isso porque ali havia, de fato, uma tentativa e esforço consciente das elites que lá habitavam, em fazer da estância serrana um lugar não apenas concorrente do Rio de Janeiro, mas, sobretudo, "distinto", onde certo controle e homogeneidade das ações culturais conferiam legitimidade a esses grupos.

Por exemplo, em 1906, quando houve a grande comemoração com os festejos em torno da Terceira Conferência Pan-Americana na capital do país, com a inauguração do Palácio Monroe, Petrópolis também recebeu a visita do Secretário das Relações Exteriores que representava os EUA, como era de praxe em todos os eventos mais importantes do Rio de Janeiro. Houve grandes festejos na chegada de Elihu Root à serra, que subiu num trem acompanhado de sua esposa, filhos e outras personalidades da política envolvidas com o evento, como o Barão do Rio Branco, Joaquim Nabuco e o embaixador dos EUA no Brasil, Lloyd Griscom, que residia em Petrópolis. A recepção já ocorreu na estação de trem, com banda de música, discursos proferidos pelo Secretário norte americano representante dos EUA, Elihu Root, e outras pessoas da 
cidade que, inclusive, faziam seus pronunciamentos em francês e inglês. A população, segundo o jornal, compareceu às ruas para o evento. Depois, o Secretário se dirigiu para o Palácio do Rio Negro, residência presidencial, e ali teve como intérprete Eduardo Rudge - que foi também fotografado (Fig. 67; 77) na residência de Sampaio, como apresentamos anteriormente (Tribuna de Petrópolis, 31/7/1906).

Todo esse evento na serra, no entanto, não foi objeto de atenção de nosso amador e nem mesmo houve alguma imagem da recepção de Petrópolis publicada nas revistas ilustradas. Isso revela não apenas a relação desse fotógrafo com a cidade, mas principalmente que a imagem de Petrópolis nesse momento era ambígua. Havia, como destacamos, por um lado, forte noção de "cidade doméstica" e, por outro, associações com a esfera do poder, seja por abrigar ali as pessoas mais representativas da vida política e social do período, seja por ter recepções importantes. Ficava reservado então como lugar da vida pública, para essas mesmas elites que viviam na serra, o Rio de Janeiro, embora elas mesmas se esforçassem para fazer de Petrópolis uma própria extensão da capital do país.

A situação seria diferente, na produção de Sampaio, somente nas cidades visitadas na Europa, na viagem de 1913 em que há ruptura, quando o artefato começa a dominar a natureza. Uma fotografia típica de transição é "A casa dos cysnes e a ponte nova de Lucerne” (Fig. 110), na Suíça. Aqui o rio tem as margens ordenadas, altamente modificadas, e as árvores são um componente do mobiliário urbano. A parte da cidade com seus edifícios e o próprio castelo dos cisnes estão situadas ao fundo, bem depois das árvores e galhos secos. A natureza, nesse caso, começa a parecer artefato.

A expressão máxima dessa ruptura aparece numa imagem que representa em último grau o domínio do homem sobre a natureza, "Estação Central do caminho de ferro em Milão" (Fig. 111). Nesse caso, o edifício, centro da atenção, é o local em que 
a cidade se interliga externamente com outras regiões do território a que pertence. Pelas dimensões da estação fica evidenciado que essa é uma função importante. Mas há ainda o espaço amplo de acesso ao prédio em que bondes se misturam aos automóveis, pessoas e carruagens. Devido à neve que está em toda a superfície, não há nem mesmo divisões nítidas entre o que seria a calçada e a rua, tudo está homogeneizado e, de maneira acentuada, registra-se o espaço de fluxo intra-urbano constante de pessoas, mercadorias e informações. Por isso, a articulação com o território, simbolizada pela estação, revela os componentes do que constitui de fato uma cidade e sua dinâmica urbana.

Mas a cidade se tornaria apenas objeto turístico como fica ressaltado nas fotografias de Veneza, como "Interior do pateo do Palácio dos Dodge. A esquerda a balaustrada da Scala dei Giganti” (Fig. 112). Trata-se de uma tomada muito próxima de fotografias e pinturas conhecidas desse local, porém Sampaio procura aplicar aqui alguns dos preceitos estéticos oriundos do cânone amador. Num espaço fechado e pequeno, que já fazia parte de suas preferências, ele desloca o centro da atenção, o arco, para a lateral esquerda. Faz alusão a um detalhe, procurando o seu "ponto de vista", tão valorizado nas revistas ilustradas e manuais de fotografia do período. Mas na cena em que há um esforço por produzir a fotografia "pessoal", o texto reproduzido no álbum evidencia haver contraste entre o monumento e o uso turístico do lugar:

"Vista tirada do pateo central do Palácio dos Doges, vendo-se ao fundo a entrada pela porta do Leão e a balaustrada da Scala dei Giganti. A impressão de riqueza e força que deixa o Palácio dos Dodges no espírito de quem o visita a fundo foi decididamente uma saga de gigantes de poder e riqueza que o construio. Em compensação é triste o contraste de um tal monumento com a geração dos actuaes donos de tal maravilha. Evoca-se a seda, o ouro e os aromas... carregados de riquezas e desperta-se do sonho com o vozear e inúmeros guias que vivem da grandeza do passado papagueiando nas salas do Conselho dos Dez...." 
A cidade aqui virou monumento, não há nem mesmo pessoas, por isso é a expressão maior do artefato que, por ele pode ser metonimizado. Mas há um contraste, acentuado por Sampaio, entre o passado e a cultura turística que diz como se deve ver o lugar, orientando o olhar e, por certo, a contemplação. Um estranhamento muito esperado de um amador que, na sua formação, valorizava a cidade como um híbrido de artefato e natureza, e procurava construir uma obra "pessoal" até mesmo nas exceções, como os registros dos eventos urbanos no Rio de Janeiro, conforme analisaremos a seguir.

\section{Vida Urbana}

As imagens desta série tratam de aspectos da cidade que de fato interessam pouco a Alberto de Sampaio, por isso, o conjunto é desarticulado. Em geral, registram-se atividades específicas na cidade, principalmente comemorações. São, no entanto, ocasiões singulares que carregam de maneira exacerbada um tipo de relação com a cidade não encontrada na maior parte da produção desse amador.

Há poucos registros de eventos em Petrópolis no espaço público, apenas 4 fotografias, um número muito reduzido se compararmos com a produção de imagens da natureza, rios e árvores, que analisamos anteriormente. Aqui a relação que Sampaio tinha com Petrópolis e, sobretudo, a idéia de que eram as famílias de elite que interferiam diretamente na vida social da cidade, se manifestarão também no caráter de domesticidade das cenas de eventos.

A primeira fotografia foi realizada em 1899, cujo título era a "Procissão em Petrópolis" (Fig. 113). Embora o evento religioso seja o tema há, sintomaticamente, maior valorização das massas de vegetação. No primeiro plano, uma cerca, quase que improvisada, indica que o terreno era ainda desocupado. Trata-se da área onde, anos 
mais tarde, iria ser construída a catedral neogótica de Petrópolis, um projeto antigo mas que só foi concluído na segunda década do século XX, com a mobilização da população local. A área é estratégica do ponto de vista urbanístico, pois o terreno que está no último plano da fotografia - onde é possível perceber uma grade que delimita o espaço público do privado - havia a antiga residência da Princesa Isabel, que desde a década de 1890, abrigava a Legação Alemã. A informação é relevante porque em frente à essa residência ficava uma das ruas mais importantes de Petrópolis, a avenida Koeler, cujo rio central havia sido retificado no projeto urbanístico original. Isso quer dizer que a poucos metros da fotografia de Sampaio, para onde essas pessoas estavam se direcionando, havia outro cenário, muito registrado pelos profissionais que atuaram em Petrópolis. A fotografia da entrada da avenida Koeler era quase como um padrão, quando se queria mostrar a cidade serrana enquanto espaço moderno. Uma imagem que Sampaio jamais realizou mesmo quando estava muito próximo a esse local.

Em 1907 foram feitas outras três fotografias do desfile de carnaval na rua em que Alberto de Sampaio residia. Uma dessas imagens é "Carro standarte, carnaval" que ressalta a ação, em detrimento do espaço público, diferentemente da fotografia anterior (Fig. 114). Aqui o entorno tem menor importância, há apenas pequena indicação da residência ao fundo e extrema valorização do próprio carro decorado, que ocupa o primeiro plano. Nesse caso, o fotógrafo se aproxima do acontecimento, está no meio da rua e, por isso, registrou algumas pessoas que olham para a câmera.

É preciso ressaltar que a proximidade ao evento ocorria num momento em que Sampaio mais realizou imagens de seus filhos fantasiados no quintal, quando introduzia fortemente a dimensão lúdica nas fotografias, em encenações gratuitas que não objetivavam resultados específicos. O interesse pelo desfile de carnaval se vincula a essa fase de sua produção, em que havia forte carga de encenação. A natureza deixa 
então de ter papel preponderante devido a essas nuances de comicidade, que seriam ressaltadas apenas na zona doméstica do espaço público, pois ele estava aqui em frente à sua própria casa.

Situação totalmente diversa ocorrerá no Rio de Janeiro, no momento em que o fotógrafo documenta eventos sociais e demarca a experiência coletiva de forma mais ampla. Nesse caso, a exceção se deve certamente ao impacto das mudanças urbanas (que ocorreram com a Reforma Passos), na idéia de cidade de Alberto de Sampaio. Ele, que nasceu no Rio de Janeiro e estudou para se tornar advogado na própria capital do país, fez sua primeira imagem num "Piquenique na Gávea" (Fig. 1), ou seja, utilizou a natureza carioca essencialmente como cenário ou espaço de fruição. Não havia interesse em registrar o que fazia parte de seu cotidiano, como os lugares percorridos entre sua residência, no bairro do Rio Comprido, e o edifício da Faculdade de Direito, situado em frente ao Campo de Santana, ou ainda outras regiões do centro do Rio também freqüentadas pelas elites. O espaço externo era apenas dominado pela natureza atuando como temática principal (ou de maneira secundária, como cenário, no caso do registro de pessoas).

A percepção da cidade como espaço urbanizado, em que certo tipo de evento significativo começa a ser documentado, ocorre apenas a partir de 1905, com a inauguração da Avenida Central. É de se compreender o impacto ocasionado pela reforma urbana não só na sua dimensão física, mas sobretudo no que se refere à percepção do lugar onde se desenrolava a vida citadina. A situação ocorreu em meio a conflitos e custos sociais elevados, como foi demonstrado por inúmeros estudos, o que contribuiu para adensar o imaginário dos acontecimentos, seja louvando a chegada da “civilização", num afastamento e negação de tudo o que estava associado ao passado colonial (Needell, 1995: 70), seja tecendo críticas ferozes ao novo modelo que excluía, 
mesmo fisicamente, no caso das demolições, parte da população que residia na capital do país (Sevcenko, 2003: 46).

Nesse contexto, Alberto de Sampaio e a elite da Petrópolis em que ele residia estavam plenamente associados aos benefícios e proveitos ocasionados por tais mudanças urbanas. Seu interesse pessoal pelo que ocorria no Rio de Janeiro era, certamente, bastante explícito como podemos observar num mapa oitocentista desta cidade, que contém anotações e desenhos feitos pelo próprio Sampaio, das ruas que seriam abertas ou ampliadas, assim como das áreas aterradas da região portuária. $\mathrm{O}$ acompanhamento detalhado, que o mapa revela, não iria estar presente nas fotografias desse amador, como fazia, por exemplo, Augusto Malta e Marc Ferrez. Porém, o mapa pode ser considerado um indício da mudança de perspectiva a ser adotada na cidade.

Sampaio não se preocupa com toda a cidade que havia sido modernizada, o espaço público em si, mas com a comemoração, mais especificamente o dia das inaugurações. Ele produz uma primeira imagem em 1905, na própria inauguração da Avenida Central, num dia não muito propício para fotografar, pois chovia torrencialmente. As próprias fotografias produzidas pelos profissionais nesse dia destacam muito mais um grande conjunto de guarda-chuvas das pessoas que se dispuseram participar do acontecimento. A fotografia, no entanto, já marca uma diferença, pois foi a primeira vez que ele utilizou a Kodak, com seus negativos de celulóide. Como as condições não eram muito propícias, o resultado foi uma cópia com pouca qualidade.

No ano seguinte haveria uma segunda grande festa, com a inauguração do Palácio Monroe, na ocasião da já referida Terceira Conferência Pan-Americana, evento que mobilizou a capital do país. A Prefeitura decretou vários dias de feriado contribuindo assim para demarcar a importância, não apenas das cerimônias, mas, 
sobretudo, da Avenida Central e do primeiro edifício suntuoso a ser inaugurado na região que, anos mais tarde, seria completado pelo conjunto arquitetônico formado pela Biblioteca Nacional, Escola Nacional de Belas Artes e Teatro Municipal. Mas em 1906 havia apenas o Palácio Monroe, ainda inacabado, e seu entorno trazia sinais das obras em curso.

Nesse momento, porém, em que Sampaio começa a fazer suas fotografias no espaço urbano, as primeiras imagens revelam um olhar já treinado na representação da paisagem e, por isso, nos indicam explícita diferenciação da produção dos profissionais. Serve de exemplo a fotografia tirada na rua dos Ourives em 1906 (Fig. 115). Aqui os edifícios, as pessoas e os equipamentos urbanos se integram compondo uma imagem da cidade. $\mathrm{O}$ espaço público deixa de ser um local vazio, sem a presença humana ou dos meios de transporte, como na foto da rua de Souza Franco, de 1893 (Fig. 105). Sampaio ressalta ainda a diversidade que se expressará na composição (disposição dos planos), escolha de personagens, etc. A cidade se transforma então numa síntese de vários elementos que devem ser integrados. Tal mudança, no entanto, só ocorre porque ele disponibiliza aqui o recurso do "ponto de vista", questão central para as fotografias que se pretendiam como "interpretação" e não apenas "reprodução fiel da realidade". No primeiro plano, uma mulher negra traz uma criança no colo (ela conversa com um homem que não está inteiro na imagem e, por isso, foi cortado em outras edições feitas por Sampaio); aparecem ainda tílburis, as carruagens de aluguel, que tinham um condutor e espaço para dois passageiros, muito populares do Rio de Janeiro. Ao fundo, um vendedor ambulante está com um tabuleiro na cabeça. Essas pessoas, que podem ser identificadas, são trabalhadores e nos remetem à própria matéria da Renascença em 1907, sobre a exposição do Photo-Club do Rio de Janeiro, em que, ao se referir à questão estética, o autor do artigo aconselhava aos fotógrafos: 
“[...] que se exercitem, de preferência, nos assumptos simples, de grandes linhas, em que haja uma idéia nítida, franca, porque esses são sem dúvida, os predilectos da photographia: heureux les sujets simples!" (Álvaro de Lima, 11/1907: 250, grifo original).

A aproximação do olhar que havia sido treinado na paisagem ocorre também na percepção do espaço que é fechado, restrito, e, mesmo, acolhedor, quase como as fotografias de árvores em Petrópolis realizadas sobretudo nas séries de 1905 (Fig.30). Ou seja, uma produção que antecede aos primeiros registros urbanos de Sampaio. Mas a aplicação desses preceitos no espaço urbano teria conseqüências próprias, como os cortes expressivos, acentuados, nas construções. Nesse caso, as linhas perpendiculares e diagonais dominam a organização formal e a distribuição dos planos, compondo triângulos imaginários, que conferem movimento e dinamismo à imagem. $\mathrm{O}$ equipamento utilizado também difere. Depois da inauguração da própria Avenida Central num dia chuvoso em 1905, é a segunda vez que ele utiliza a câmera Kodak, com os negativos de celulóide, para fazer registros urbanos.

Outra fotografia realizada por Sampaio nesse dia se distingue ainda mais da produção do período. $\mathrm{Na}$ imagem feita na própria Avenida Central, que registra pessoas no meio da multidão (Fig. 116), os homens no primeiro plano estão de costas e funcionam como uma moldura para o edifício situado ao fundo. O espaço é também restrito, não há valorização da perspectiva e nem mesmo do evento que estava ocorrendo, o desfile. O enquadramento se mantém nessa linguagem de cortes expressivos, inclusive, naqueles que assistiam ao evento.

Trata-se de uma fotografia amadora no sentido atribuído pela Kodak, com diferenciações. Vale mencionar que as revistas ilustradas mais "mundanas" não se restringiam às imagens bem centradas, dispondo de composição e nitidez como atributos de valor. Havia, em tais periódicos, espaço de difusão da tecnologia produzida 
para o amador, em que se exaltava não a cidade em si, mas o transeunte, o homem que circulava nos espaços modernizados. É o caso da Kodak, que era produzida e destinada aos grupos de fotógrafos amadores, mas que teve repercussão e uso ampliado na Fon Fon!, Careta e Revista da Semana.

Nessas revistas, havia colunas separadas nas quais eram publicadas imagens de pessoas surpreendidas andando nas ruas, cujo título podia ser "Fazendo avenida", "Rio em flagrante" ou simplesmente "Instantâneos" (Fig. 117). Ali mencionavam-se os nomes e sobrenomes das pessoas fotografadas, funcionando a revista como lugar de exibição e mesmo encenação social. As fotografias publicadas tinham o corpo em movimento surpreendido como objeto central, não dispondo de muita qualidade. Em certo sentido, são imagens "amadoras" tal como criticavam os homens de elite dos clubes europeus. O espaço da cidade praticamente não aparecia e o enquadramento podia, em certos casos, estar descentrado e o fundo sem foco e nitidez. Aqui não cabia o julgamento de que a fotografia tinha defeitos sob o ponto de vista estético, pois o que importava era o instante em que a pessoa registrada numa ação banal, considerada ilustre, aparecia num movimento livre e descompromissado. Os sinais de precariedade atuavam como construtores de sentido, pois acentuavam a percepção do flash e da função, que já ressaltamos, de deslocamento.

A câmera produzida para o amador, nessas colunas, transformava-se num meio de afirmação da elite e mesmo de mediação entre a vida privada e a pública. Esse tipo de publicação constituiu um padrão muito popular até a década de 1910 e 1920. Mudava-se a indumentária, mas permanecia o mesmo sentido social: a valorização da vida do indivíduo no encontro com a cidade, cuja pequena elite se reinseria no espaço público por meio dessas fotos "amadoras". Forma de apropriação ou efeito compensatório capaz de reduzir a dimensão da expansão urbana ao uso de grupos de 
privilegiados, que mantinham muitas vezes entre si laços de parentesco. Por isso, havia menção de sobrenomes que indicavam ao leitor os vínculos diretos entre as pessoas registradas explicitando, ainda, que a Avenida Central era o lugar de trânsito da “família” carioca.

Nada disso, porém, aparece na fotografia (Fig. 116) de Alberto de Sampaio. Trata-se de um uso muito específico, que fugia das convenções do período, seja dos amadores, profissionais usuários da Kodak, seja daqueles que pertenciam ao Photo-Club do Rio de Janeiro. Mas Sampaio também fez outros registros do desfile situando-se num edifício que ficava na esquina da própria rua dos Ourives. Ao alterar o ponto de observação da cena, ele se detém muito mais na parte cenográfica ou, por assim dizer, teatral do acontecimento, produzindo imagens da evolução do desfile. São sete fotografias em seqüência, das quais destacamos três, que documentam os primeiros momentos do evento, quando a população ainda chegava para a festa. Podemos observar vendedores ambulantes, mulheres, crianças, enfim, a diversidade no espaço público (Fig. 118). Há também a evolução dos grupos uniformizados que desfilam a cavalo, em bicicletas e, quando em marcha, portam instrumentos musicais ou armas (Figs. 119; 120). Nesse caso, Sampaio valoriza a perspectiva e, com isso, a extensão da Avenida. Mas o amador está posicionado numa região em que os edifícios não haviam sido concluídos. Embora seja o mesmo local em que realizara as duas tomadas no nível do observador, com a babá e a criança em primeiro plano, aqui há maior destaque para o fato de que o espaço ainda era objeto de obras. Notamos com mais ênfase os tapumes que escondiam o que estava sendo construído (no caso, na parte esquerda das imagens, o local que iria ser ocupado pelo Jornal do Commercio), assim como os andaimes situados nos prédios quase concluídos. 
A preocupação em registrar a evolução do acontecimento no espaço possibilitou a esse amador documentar a diversidade de ações e agentes. Além do tílburi no primeiro plano (na mesma rua dos Ourives), aparece um quiosque, mobiliário urbano banido da cidade pelo próprio Pereira Passos, com o argumento de precárias condições de higiene para a manipulação dos alimentos. Mas a solução encontrada pelo "modelo" registrado na fotografia foi diferente: com a mobilidade do equipamento, podia-se deslocar facilmente pela cidade e, talvez, fugir da vigilância empreendida pelo poder público. Há ainda um homem que segura um cartaz com o título "Sapatos quase de graça" (Fig. 118), o que é bastante sugestivo, visto que um projeto de lei da época proibia andar descalço precisamente na Avenida Central (Pereira, 2004: 147). Era a luta, como diz Sevcenko (2003: 46), contra os "velhos hábitos coloniais".

É preciso destacar ainda as diferenças dessas imagens para aquelas que foram produzidas por profissionais. De novo, Augusto Malta nos oferece um exemplo bastante significativo, até porque era o fotógrafo contratado pela própria Prefeitura para documentar os eventos e, além disso, também publicava suas imagens nas revistas ilustradas. Em 1906 aparecem registros do desfile na Kosmos (Fig. 121). Encontramos, nesse caso, aquilo que Ana Maria Mauad (2008: 120) observou como sendo a preferência de Malta: trata-se de imagens situadas no "res do chão", em que se valorizava a inserção no espaço, o movimento urbano e, mesmo, a relação recíproca entre o fotógrafo, como participante, e a cena documentada.

O resultado, porém, foi muito diferente das tomadas de Sampaio, pois o fotógrafo profissional estava situado um pouco acima da posição dos pedestres, talvez, numa carruagem. Por isso, estando no meio da multidão, pôde valorizar a perspectiva: ele estava imerso mas tinha visão de conjunto. Logicamente, a idéia de aglomeração urbana seria fundamental para expressar o próprio sucesso do acontecimento. $\mathrm{O}$ 
posicionamento espacial valorizaria então o agrupamento e os edifícios do trecho da Avenida Central que estavam todos concluídos, transmitindo a idéia de que as obras haviam terminado e que essa era a nova "realidade" daquele lugar. Mas isso foi apenas uma escolha de posicionamento para passar tal impressão, como observamos nas imagens de Alberto de Sampaio que nos mostram os prédios inacabados e a Avenida ainda em obras.

Desta forma, a fotografia de Malta apaga qualquer sinal de contradição e a arquitetura das fachadas é um elemento chave para essa "construção" do espaço, porque os edifícios suntuosos acentuavam a perspectiva conferindo monumentalidade. Podemos inclusive notar as pessoas nas janelas, que nos fornecem a exata proporção, tamanho e impacto da série de construções ordenadas em seqüência. Em termos de composição, há, ainda, um único ponto de fuga, para onde converge nossa atenção, no último plano, um pouco fora de foco. Este recurso ressalta a extensão da Avenida, que continua mesmo onde não podemos mais ter acuidade visual, no lugar distante. Tudo muito diferente da fotografia de Sampaio na rua dos Ourives (Fig. 115), em que a diversidade de planos confere movimento à cena. As diferenças são maiores quando pensamos nas pessoas que foram objeto de atenção, os trabalhadores, vendedores ambulantes, enfim, os habitantes que eram simples espectadores e que estavam, de fato, excluídos da modernização em curso. Já na fotografia de Malta, além daqueles que assistiam à comemoração, observamos no meio da multidão um "carro à Daumont", viatura de luxo que foi utilizada nessa festa, segundo Noronha Santos (1996: 116). No seu interior, havia os personagens da política, reconhecidos facilmente pelos leitores da revista Kosmos: o Barão do Rio Branco e Elihu Root, Secretário americano representante dos EUA naquele evento. 
As fotografias de Sampaio registram assim um quadro mais expressivo de ambivalências, sem ter, no entanto, esse propósito inicial. Se esse amador revela os próprios sinais conflituosos do cenário inacabado da Avenida Central, seus habitantes mais modestos, os vendedores ambulantes, e aqueles que podiam aproveitar verdadeiramente a chamada "Regeneração", é porque ele dialoga com certos cânones relativos à tal cultura amadora de elite. Porém, ele usa a Kodak. Havia, em geral, registros mais "amadores" no próprio sentido atribuído ao equipamento - no caso específico do desfile, em que os edifícios da Avenida Central estão um pouco inclinados, numa distorção da perspectiva. Mas essa câmera também servia para um uso elaborado em que elementos das discussões estéticas são aplicados numa observação cuidadosa. Ressalta-se, desta forma, o cenário de dicotomias, ou mesmo, de hibridismo, pois o equipamento portátil servia para realizar imagens com diferentes critérios de composição e não somente os famosos instantâneos.

\section{Família na cidade}

As fotografias da família de Alberto de Sampaio em espaços públicos são exceções dentro do acervo. Nas imagens associadas a atividades urbanas, incluindo algum membro da família em Petrópolis ou no Rio de Janeiro, havia sempre predomínio da natureza e, em certos casos, apuro estético, preocupações de composição ou, seu oposto, como nas cenas em que o amador utilizou a câmera Kodak (Fig. 3).

Foi somente na viagem à Europa em 1913 que Sampaio faz as primeiras cenas incluindo grupo doméstico em imagens de cidade. O conjunto aqui tratado estará, portanto, prioritariamente vinculado a esses registros, que serão analisados seguindo as recorrências espaciais e de comportamento no espaço público, como "natureza, parques 
e jardins", "rua", "comportamento turístico padrão", "monumentos" e, por último, "vida urbana (cafés)".

Começaremos, no entanto, por uma das poucas fotografias realizadas no Brasil, em que membros da família Sampaio aparecem numa cidade, a fim de demarcar as diferenças com as imagens realizadas no Exterior. Trata-se de "Grupo, meninos na fonte" (Fig. 122), de 1908, realizada em Cambuquira. Ali foram registrados os seis filhos de Sampaio (Álvaro, João, Bento, Alberto, Luiza e Eduardo) com sua esposa Cecília, todos encostados no gradil de madeira que protegia a fonte de água. Nesse caso, é preciso considerar que a cidade era de veraneio; havia predomínio da natureza e as atividades de caráter especificamente urbano não tinham relevância. O espaço do entorno, dominado por vegetação e cursos d'água, constituía o atrativo dessa estância termal, muito procurada pela elite carioca.

Tais circunstâncias irão certamente condicionar a postura e relação das pessoas com o espaço. O corpo das crianças, por exemplo, aparece mais desmobilizado, revelando o descompromisso da situação: sobem no gradil e sentam-se comodamente na estrutura. Vale lembrar que, nessa mesma ocasião, Sampaio fez diversas fotografias de árvores num bosque em Cambuquira, conforme já destacamos. Portanto, predominava uma relação próxima e íntima com o lugar, que se expressa na maneira livre e relaxada com que eles se deixam fotografar.

Nas cidades visitadas nos países europeus haveria bastante diferença. A roupa e os gestos revelariam ali certa formalidade, como na cena em que Cecília aparece em Versalhes, "Bassin D’Appolon" (Fig. 123). Mas há outra questão importante: o espaço, nesse caso, é amplo, e desproporcional a relação estabelecida com a presença humana, de forma contrária às convenções estéticas vigentes. Como se trata de um fotógrafo tão dedicado e habilidoso como Sampaio, sabemos que não é uma falta de recurso, 
dificuldade técnica ou desconhecimento que o levou a produzir uma imagem que seria, de fato, padrão para o iniciante na atividade. Talvez houvesse um sentido positivo, ou mesmo efeito compensatório, em cenas em que tal desproporção estava marcada, pois o amplo espaço pode também expressar a apropriação do lugar por quem está sendo representado.

Situação semelhante ocorre na Suíça em que membros da família Sampaio aparecem juntos em "Grupo em Lucerne" (Fig. 124) - provavelmente foi um dos filhos que registrou a cena. $\mathrm{O}$ espaço, talvez um parque, é dominado pela natureza, mas o grupo tem postura diferenciada e roupas altamente formais. A indumentária de Sampaio é representativa, pois ele está com bengala, chapéu (mais inclinado para frente) e luvas de couro. Mais uma vez o recurso do espaço amplo no primeiro plano, que parece uma sobra, um excesso e, sob determinado ponto de vista, até mesmo um defeito, cumpre a mesma função compensatória descrita anteriormente.

Nas imagens realizadas na série das "ruas", que são muito poucas, tais questões também estariam presentes como em "Uma viella em Lausanne" (Fig. 125). Nesse espaço estreito com muita vegetação, todo o primeiro plano é composto pela perspectiva do logradouro pavimentado e as pessoas ficam lá no fundo, formalmente dispostas. A desproporção é, então, notória, o que acentua o espaço demarcado, ou mesmo, particularizado pela presença do turista na imagem.

Outra série fotográfica, realizada no espaço externo, é a que ressalta a relação com o "monumento", que é a expressão maior do artefato, porque funciona como uma síntese da cidade como um todo, tendo caráter metonímico. Nesse caso, Sampaio pode até dialogar com o formato do cartão postal e faz algumas encenações, apresentado seus familiares como se pertencessem ao lugar. Isso ocorre no "Castello de Saint-Germainen-Laye" (Fig. 126) situado em Paris, em que o palácio, como um monumento, é o 
objeto central da imagem. Na praça situada em frente à construção várias pessoas estão caminhando; na parte central encontra-se Cecília e, no sentido contrário, seu irmão João com a esposa Sissy - ambos olham para a câmera. Sampaio dirige a cena para produzir uma impressão de acaso e de instantâneo nesta imagem. A convenção se estabelece aqui evidenciando o papel que os postais tinham na constituição de um modo de ver a cidade e se representar como parte integrante dela.

De fato, os cartões postais constituíam um meio de comunicação extremamente popular. Como vimos, Sampaio forma sua grande coleção de postais entre 1902-1904 após o anúncio na Lectures pour tous. Mais tarde, continua trocando esse tipo de suporte entre amigos e familiares, inclusive, no período anterior e durante essa estadia na Europa. Mesmo quando um de seus filhos ficou durante um ano em tratamento de tuberculose na Suíça (em 1912, momento que antecede esta viagem à Europa), o principal meio de comunicação entre os parentes eram os postais. Não é de se estranhar, portanto, a pertinência do modelo difundido naqueles anos, que podia se evidenciar na produção desse amador: tanto nos registros de edifícios isoladamente como nas tomadas de sua própria família numa simulação de serem os passantes, conforme os próprios moradores locais.

Já o registro de monumentos está vinculado ao mesmo problema de representação espacial destacado na série dos parques. Em "O Duomo de Milão" (Fig. 127), por exemplo, Sampaio, Cecília e João estão na praça, espaço de passagem e articulação. As pessoas andando e outras sentadas de maneira informal no gradil são do local e, portanto, têm postura corporal mais relaxada, podem inclusive recostar-se na grade em metal. Mesmo o garoto, na parte direita, que olha para o equipamento, faz parte do conjunto, se assemelhando pelas roupas e postura corporal às outras pessoas 
documentadas naquele lugar. O grupo de família, diferentemente, está de pé e formalmente vestido, não interagindo com o entorno, somente com a câmera.

Temos aqui a cidade na sua dinâmica: o uso do espaço pelas pessoas que transitam diariamente ali, os meios de transporte e, em destaque, o turista. Por isso, mais uma vez, o registro das pessoas - em sua dimensão pequena, em contraste com o edifício monumental - marca a presença desse visitante, particularizando o momento. Revela também certa apropriação do espaço. Contudo, trata-se de uma apropriação terceirizada, pois remete à fotografia o que não pode ocorrer na experiência subjetiva. Isso porque o objeto do turismo vira mercadoria e a relação transitória é mediada pela superficialidade.

No "comportamento turístico padrão" - a última série - acentua-se o problema da convenção turística, em que a repetição de imagens, incluindo os "defeitos", tem certa função imagética. Tais questões aparecem na fotografia "Eu e Cecília com os pombos, S. Marcos [Veneza]" (Fig. 128) cujo espaço é restrito o suficiente para se concentrar na ação sugerida. A Basílica de São Marcos conta muito pouco, o que interessa é a praça como local onde os turistas repetem indefinidamente uma típica ação: alimentar os pombos. Barbara Levine (2007: 25) aponta algumas direções em que talvez possamos questionar nosso acervo, pois, esse tipo de "fotografia de confirmação" ocorreria porque "the personal camera enabled tourists at last to personalize and privatize an experience of a particular place or monument". Seguindo tal abordagem, as imagens mais convencionais, em que turistas aparecem ao lado de parques e monumentos, mesmo quando "mal feitas" sob o ponto de vista estético, são altamente representativas. É quando o turismo enquanto evento coletivo é transformado em experiência particular pela produção de imagens do amador. Daí a repetição de cenas cujos "erros" passam a integrar determinada convenção, que pode ser entendida como um "snapshot": termo 
empregado para a produção amadora associado a câmeras portáteis, em que a mobilidade e a suspensão do tempo passam a construir novos objetos visuais.

Em outras fotografias, desse mesmo dia, tais questões ficam mais evidentes como em "John e Álvaro com os pombos [Veneza]" (Fig. 129). Nesse caso, com os dois filhos de Sampaio alimentando os pombos, o espaço se restringe estritamente ao evento (aqui é uma fotografia do próprio Sampaio, diferentemente da anterior, em que um de seus filhos faz o registro). Há, entretanto, uma diferença, que é preciso destacar: trata-se da postura corporal do casal, que está de pé, sutilmente alimentando os pombos, revelando assim preocupação com a postura formal; já os filhos mais jovens estão abaixados, em plena ação, num maior envolvimento com o evento.

Nessas fotografias o que vale é muito mais a experiência no lugar do que o espaço em si. A questão estética é colocada de lado e o sentido do "mal feito" encontra sua legitimação. Não importa aqui a distribuição dos planos ou a iluminação mais elaborada. Os problemas de exposição, desta forma, exercem papel secundário como a própria fotografia anterior em que o primeiro plano está fora de foco e, mesmo assim, não se diminui a importância da tomada.

Vale mencionar que todos esses registros são situações típicas da atividade turística e dialogam com determinado padrão, em que a fotografia é mediada pela experiência da viagem, tendo função memorialística. Como ressalta ainda Barbara Levine (2007: 25), a fotografia, nas viagens, é um meio de os indivíduos conferirem continuidade, organizarem o presente em termos daquilo que merece ser lembrado. Tal seleção está vinculada ao uso posterior, uma vez que a viagem se completa no momento do relato para o grupo familiar. São imagens com caráter muito mais projetivo, daí Sampaio ter dado importância aos álbuns que contêm relatos escritos. 
Por último, trataremos da "vida urbana", que resume determinado consumo de lazer urbano em espaços de transição. Trata-se de cafés, confeitarias, restaurantes em estações ou no próprio trem. Mas a produção de Alberto de Sampaio não é documental, e esse tipo de cena constitui assim uma exceção, como a fotografia "Cecília dentro da confeitaria Pamela" em Paris, (Fig. 130). Há no álbum um texto acompanhando a imagem. A observação de Sampaio ressaltava propriedades do espaço, pois a confeitaria era "anexa ao hotel Jena com a qual comunica com uma porta interior", e "onde tomamos muitas vezes um five o'clock tea e comemos doces muito gostosos". O salão com seus móveis e decoração é valorizado, sendo um lugar de passagem e de um tipo de sociabilidade impessoal. Poderíamos aproximar aqui daquilo que André Rouch (1995: 101) fala sobre o problema da espacialidade viagem turística. Haveria duas vertentes que se complementam e estão em conflito: por um lado a rota, os caminhos de acesso e, por outro, o tempo do olhar, da apreciação da paisagem e do monumento. Os intervalos da viagem, em restaurantes e cafés, por exemplo, permitem complementar visualmente o próprio itinerário do deslocamento. Vale lembrar que Petrópolis e Rio de Janeiro tinham diversos cafés, alguns inclusive famosos. Porém ali a freqüência a tais estabelecimentos não se constituía num intervalo, mas, ao contrário, integrava hábitos cotidianos no espaço urbano, que nunca se converteram em fotografias.

\section{A cidade doméstica e outras cidades}

É no registro de cidades que, numa exceção, a fotografia como documento e memória tem presença, seja nas comemorações públicas na cidade conhecida, seja na viagem como turista à cidade estranha - em que há maior necessidade de fazer registros também escritos, que complementem as imagens. Observamos também que a cidade artefato só começa a ser evidenciada a partir da Reforma Passos, por representar a 
inserção do Rio de Janeiro no mundo moderno. Mas mesmo depois da descoberta da cidade via capital do país, continua a predisposição para valorizar os elementos da natureza e a vida no campo.

Mas por que Alberto de Sampaio, que tinha vida social ativa em Petrópolis, não demonstra interesse em fotografar a vida urbana? Todas aquelas festas em clubes, conferências literárias, bailes no Palácio de Cristal eram percebidas até mesmo por quem visitava a estância de veraneio, pelo menos é o que indica Clarice Ehlers Peixoto (1995: 128) sobre as imagens produzidas por Dutertre em Petrópolis, fotógrafo que trabalhava para o banqueiro Albert Kahn no projeto Archives de la Planète. Entre 19091912 (data estimada), esse fotógrafo esteve na cidade serrana e lá produziu duas imagens em autochrome que valorizam o elemento urbano com ruas, carruagens e pessoas nos espaços públicos, ao contrário do Rio de Janeiro que foi registrado, por ele, sob a ótica da paisagem natural, conforme aponta a autora.

A preferência de Dutertre em ressaltar os meios de transporte, a estação de trem, dando ênfase à rua em movimento se contrapõe ao olhar de Sampaio, exatamente o morador da cidade, que participava da própria organização de diversos eventos. Esse aparente antagonismo revela duas questões importantes: a primeira é a relação entre a vida pública e doméstica em Petrópolis; e a segunda, se refere ao modelo de fotografia que seguia o cânone artístico, aconselhado pelos fotoclubes amadores.

É possível então afirmar que, em Petrópolis, a vida pública era uma extensão da vida doméstica, da vida da família de elite, de maneira muito mais acentuada do que na capital do país. O estudo de Júlio Ambrozio (2008: 242), já mencionado, nos auxilia a compreender melhor esse processo, uma vez que o autor ressaltou a idéia de que Petrópolis havia sido planejada como uma "cidade doméstica". O espaço assim 
concebido para a vilegiatura era instância privilegiada para a vida da família de elite no âmbito de suas residências particulares.

O problema da cidade doméstica pode ser evidenciado nas formas com que esses habitantes se organizavam, promoviam encontros e festas. Merecem destaque as "visitações", o hábito de percorrer as casas como uma prática social, vigente de forma mais ampla na sociedade do período, mas que tinha relevância acentuada na cidade serrana. Mariana Muaze (2008: 193) nos fornece um interessante exemplo de como funcionava essa rotina, analisando a descrição em cartas dos Ribeiro Avellar, quando estavam em Petrópolis. Afinal, era de "bom tom", cada vez que chegavam à cidade, iniciarem as visitas aos amigos mais próximos ou mesmo às pessoas com que tinham relações e interesses formais.

A importância conferida aos jardins como parte privilegiada da arquitetura doméstica, constitui outro ponto que demarca a relevância dos espaços privados. Aliás, quando paisagista e botânico francês Auguste Glaziou ${ }^{87}$ reformou no Rio de Janeiro o jardim público do Campo de Santana, em Petrópolis, foi também contratado para realizar o jardim da residência da família Tavares Guerra. Mas nada foi realizado no espaço público, diferentemente da capital do país.

No início do século XX, com todas as mudanças que ocorreram, embora houvesse esforço para prover a cidade de locais públicos aprazíveis, permanecia a relação, por certo, de relevância da vida doméstica da elite. Isso se manifestará na presença dos diplomatas e legações estrangeiras, que funcionaram como outro pólo aglutinador para a manutenção da importância da vida social no âmbito doméstico. Os constantes

\footnotetext{
${ }^{87}$ Auguste Glaziou (1883-1906) veio para o Brasil a convite do Imperador D. Pedro II em 1858 e aqui implementou projetos importantes como a reforma do Passeio Público e do Campo de Santana no Rio de Janeiro, dentre outros. Teve vários cargos como diretor de parques e foi, inclusive, membro da Comissão Exploratória do Planalto Central em 1892, liderada por Luis Cruls, diretor do Observatório Astronômico do Rio de Janeiro (Santos, 1944: 165).
} 
comentários do que ocorria dentro dos principais palácios, publicados nos jornais da cidade e mesmo nas revistas ilustradas, como Kosmos e Renascença, contribuíam para reafirmar que era dentro dos recintos privados, onde adentrava uma pequena parcela da população, que se exercia no mais alto grau a vida pública.

Elysio de Carvalho ${ }^{88}$ fez observações que nos auxiliam a entender essa questão. Em 1909, mesmo ano em que proferiu palestra, no ciclo de conferências literárias organizadas pelo Club dos Diários, publica longa matéria sobre os diplomatas de Petrópolis, na própria Kosmos. Ao comentar as festas organizadas na residência da esposa do ministro do Uruguai, Maria Luiza Gomes Cibils Dominguez, ele faz também referência direta a algum manual de etiqueta francês:

\begin{abstract}
"De facto, Ella [Maria Luiza G. C. Dominguez] exerce todas essas qualidades em virtude de um dom raro, a urbanidade que a torna uma exemplar dona de casa. "L'urbanité, mot digne et charmant, comme la qualité qu'il représente, requiert une constante vigilance [...]. Les places à donner à table, les ègards dus aux visiteurs, surtout, aux ètrangers, et tant d'autres soins, trop souvent nègligès, dans nos pays mêmes, tels sont les offices pratiqués excellemment par la vraie maîtresse de maison. Type qui se fait de plus en plus rare" (4/1909, anno VI, n.4).
\end{abstract}

Esse artigo é bem representativo do conceito de vida social compartilhado pelas elites de Petrópolis, para quem a "urbanidade" se exercia no âmbito doméstico, exigindo, portanto, saber organizar uma mesa de jantar, receber os convidados, enfim, responsabilidades do universo feminino. Em outro trecho do mesmo artigo, o autor menciona as festas ocorridas no âmbito do antigo Cassino Fluminense que, como vimos, havia sido antes dos "Diários", o principal clube de elite do Rio de Janeiro e de Petrópolis, conhecido por ter promovido os bailes mais suntuosos na cidade serrana.

\footnotetext{
${ }^{88}$ Elysio de Carvalho (1880-1925) foi autor de vários livros, um dos mais conhecidos, Five o'clock (1909), é ambientado no Rio de Janeiro e em Petrópolis (e dedicado a Paulo Barreto, João do Rio). Abordou em seus livros temática criminalística e dirigiu a revista Kultur (1904), ligada ao anarquismo (Salgado, 2006).
} 
Compara então aquelas festas com as últimas recepções ocorridas na residência do casal Dominguez, alusão, por certo, significativa. Isso porque ao recuperar o sentido anterior de "cidade doméstica", em plena primeira década do século $\mathrm{XX}$, quando tudo era diferente, ele reintroduz aquela elite num espaço social desejado, no momento em que havia ameaças à estabilidade desses grupos, sobretudo no âmbito econômico.

Estando situado nesse contexto, é possível supor que Alberto de Sampaio conferia tão pouca importância à representação de aspectos urbanos em Petrópolis porque, para ele, o que mais importava ali era a vida pública enquanto vida doméstica. Mas certamente há uma segunda questão, que nos remete ao campo fotográfico amador e à relação com a natureza, em oposição à cidade.

Dentro do circuito fotográfico dos clubes, onde já mencionamos as fortes convenções estéticas, os amadores não incluíam em seus temas a problemática urbana. A preocupação estava na natureza, nos lugares incomuns, na representação de um tipo de vida não contaminado pelos aparatos tecnológicos de que a própria fotografia era integrante. Na aproximação canônica com a pintura havia rejeição à tecnologia, sem, porém, dispensá-la. Sinal de ambiguidade compartilhada pelos grupos amadores, que liam revistas especializadas, jornais publicados pelas sociedades, que tinham seus laboratórios e podiam, de alguma forma, pelo domínio técnico da atividade, não apenas se equiparar aos profissionais, mas, sobretudo, mostrar certa superioridade.

Porém, ainda é preciso ressaltar o papel da viagem à Europa, em 1913, para a fotografia urbana de nosso amador. Trata-se de uma produção visual já ancorada num "repertório de viagem" composto por guias produzidos para o turista, cartões postais ou mesmo o cinema, com seus filmes de cidades e paisagens de diversas partes do mundo, característicos da primeira década do século XX. Nesse sentido, conforme ressalta Barbara Levine (2007: 79), a fotografia, na atividade de turismo, se transforma muito 
mais num "process of confirmation than of discovery". Na produção de Alberto de Sampaio sobre as cidades européias, essa questão fica evidente. No entanto, como esse amador oscilava entre um maior comprometimento com a prática clubística e o forte interesse pela fotografia como uma forma de comunicação, ou mesmo divertimento, notamos tal oscilação também nas imagens produzidas nas cidades visitadas. Nessa produção européia, haveria, no entanto, uma particularidade: quando o que valia era a repetição do gesto e da convenção, próprias da atividade turística, surgem as primeiras cenas da família no espaço urbano. 


\section{CAPÍtulo 5. CONCLUINDO: PARA QUE SERVE A FOTOGRAFIA AMADORA?}

Em 21 de abril de 1907 Alberto de Sampaio redige, de maneira fantasiosa, a ata de fundação de um suposto clube em Petrópolis (Anexo I). Datilografado em duas laudas, autenticadas até mesmo com aposição de carimbo e lacre, o documento se expressa na linguagem arrevesada do direito e dos cartórios, entremeada de inserções e de extravasamentos afetivos. Há partes sublinhadas e letras em maiúsculo que acentuam os trechos que seriam mais importantes. O texto não se intitula contrato, nem ata de fundação, mas se trata de um "pacto". Ele menciona como motivação da proposta a "necessidade de perpetuar a obra do finado Comité, embora em círculo mais estreito e em esphera de diâmetro mais reduzido...”. Em suma, incluiu entre seus comparsas no pacto membros do Club dos Diários, que haviam participado do comitê para organização do "Verão em Petrópolis" em 1906. Era, portanto, formado por um pequeno grupo de amigos.

O texto define como objetivo principal permitir a "Máxima Conivência e Convivialidade" entre aquelas pessoas. A fotografia só é mencionada depois, na segunda cláusula do pacto. Mas estava integrada a uma série de atividades diversas como a poesia, o piano, o teatro, a equitação, o pedestrianismo e o pic-nic.

A responsabilidade principal daqueles pactuantes consistiria principalmente em desenvolver o gosto pelo "cultivo" dessas artes liberais (“ou não", como acrescenta). 
Todas as atividades que lá constavam era para serem praticadas, e não simplesmente para fruição de um espectador passivo. Serviam ao "homem cultivado", isto é, que se cultivava espiritual e corporalmente, portanto homem distinto, já que se distinguia daquelas classes inferiores que não procuravam ou não dispunham de recursos para investir no seu refinamento. Tudo compartilhado, obrigatoriamente, no "Doce convívio de pessoas amigas”. O propósito dominante, pois, era sedimentar laços e garantir solidariedade, tudo alimentado pelo afeto, pela diversão, pelo lúdico, pelo humor. Era um propósito que não poderia assentar-se em outros fundamentos, como os de natureza política, econômica e profissional.

A maneira descompromissada de se expressar e os exageros permitem trazer à tona, ao menos na vertente representada por Alberto de Sampaio, o que dava inteligibilidade e interesse à fotografia amadora. Cremos ter apontado nessa direção, quer no exame das fotografias, quer nos demais quadros de atuação de nosso fotógrafo. Não se tratava de uma fotografia documental (salvo as exceções apontadas), nem mesmo de imagens em que o problema da representação fosse dominante. Por isso, o pacto é altamente relevante.

Pode-se, portanto, confirmar o que foi dito sobre o papel (preponderante) de prática comunicacional representado pela fotografia. E, além disso, que no acervo aqui estudado, seria esta sua função principal. Nisso, a contribuição do lúdico foi essencial.

O caso da fotografia de família é exemplar, por sua vez, para se concluir da pouca motivação documental do registro fotográfico. Nada daquilo de que falam os historiadores, principalmente depois de Bourdieu - que, entre nós, é ecoado por vários autores, dentre eles Nelson Schapochnik (2001: 457-60) - "solenizar e eternizar os grandes momentos" -, dando a esse gênero a missão de preservar os pontos culminantes da vida do grupo: casamentos, festas, batismos, etc. A fotografia estaria assim destinada 
à memória familiar, com a gestão feminina sendo a norma. Sampaio, ao contrário, se preocupa com o que é repetível, com o aprazível do cotidiano entre familiares e amigos, e não com aquilo que é singular, que pode ser momentaneamente intenso, mas logo se esvai. Daí a importância das encenações, do humor, enfim, do lúdico. As exceções confirmam a regra: a série do Rio de Janeiro respondeu a um impacto maior da transformação da paisagem urbana - para inserir o país no "concerto das nações" -, impacto relevante, mas que não deu outros frutos. Já as cidades européias e respectivas lembranças fotográficas constituíam um espaço de alteridade e de situação singular e, ao mesmo tempo, oportunidade de prática de convenções que nobilitam nosso fotógrafo $e$ sua família.

Quanto à natureza nota-se a mesma preocupação, em particular, nas séries que ele mais prezava. Trata-se das árvores em Petrópolis, que receberam menções no caderno de anotações, com títulos e composição semelhantes. Na série encontramos registros em que se alteram as espécies, mas a composição permanece a mesma, em todas as imagens. Também aqui não se reforçam idéias de transformação, mas de permanência. Somente há variações nas condições de iluminação, que contribuem para ressaltar ou fundir elementos do quadro registrado. Seja como for, o gosto pela natureza era de bom tom para o homem cultivado e poderia até se equilibrar com uma intervenção, nela, de tipo capitalista, tecnológica. Além de tudo, não era necessário que isto evolvesse questões de identidade nacional.

Podemos então concluir que, naquele momento, entre o amador e o profissional não existiam dicotomias rígidas (ao menos antes da "democratização kodakeana da fotografia"). A diferença principal não estava na competência técnica, nem no domínio de conhecimentos ou padrões estéticos, mas nos usos das imagens. Isso porque para o 
amador a fotografia não é mercadoria, ele não vive disso. As trocas ocorriam na circulação familiar, entre amigos. Há também uma tônica conservadora aqui.

Ressaltamos, por fim, que apesar do trabalho ter dado foco muito intenso numa única figura, devido à excepcional disponibilidade de fontes - em comparação com a escassez de fontes de maior alcance e da reduzida bibliografia, o resultado não é exclusivamente biográfico. Permite alcance maior, que é o entendimento e variabilidade da cultura amadora, dentro da qual Alberto de Sampaio pode ser tomado como um dos padrões relevantes. 
ANEXO

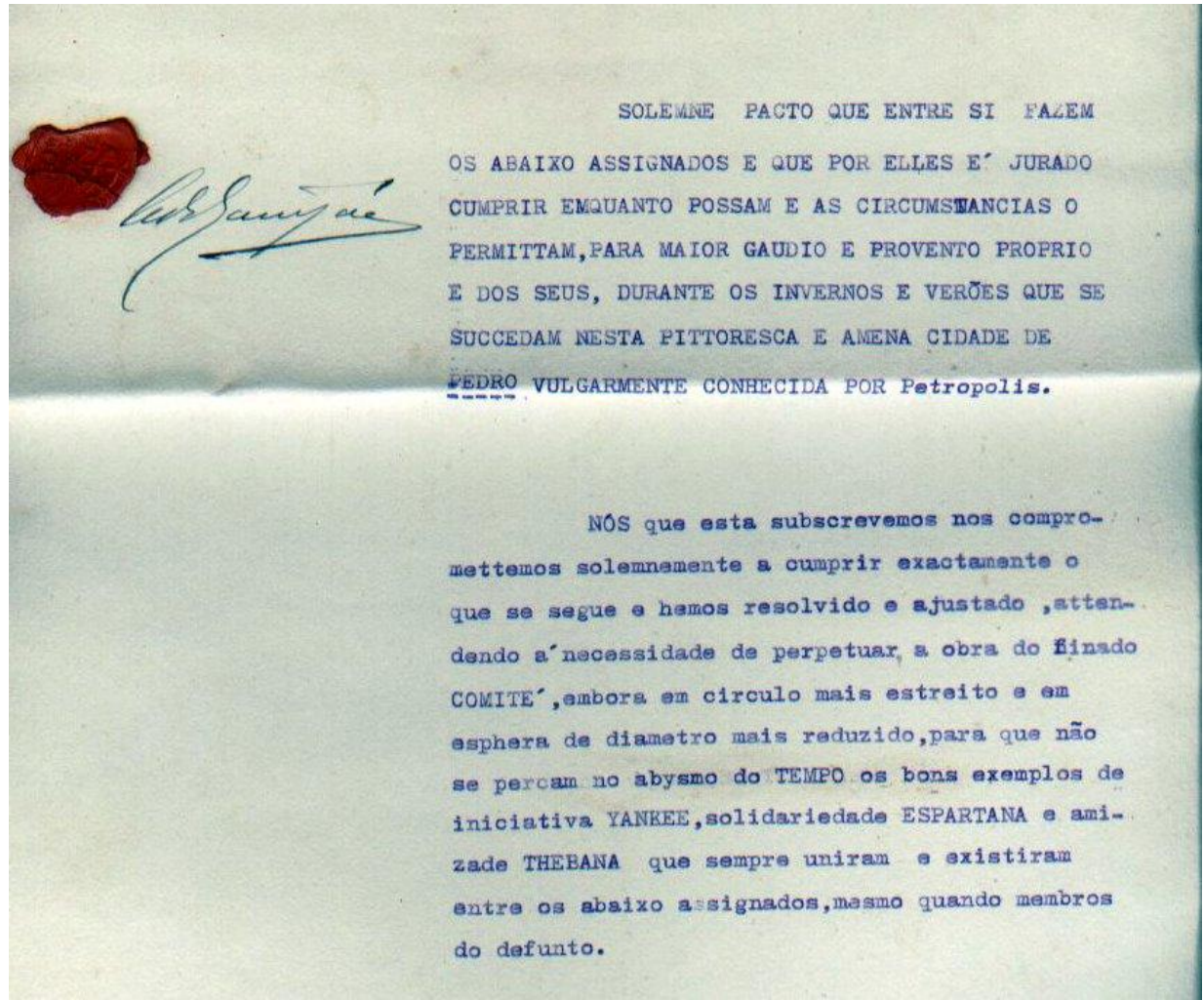

Attendendo $a^{\prime}$ necessidade de aç̧ão que

e' commum aos homens, e mulheres tambem, a a espirito de associação, gerador das mais fecundas dascobertas do genero humano inclusive a da AMaRICA, resolvemos nos colligar contra o tedio a isolamento dos frios hibernaes originadores do egilstico agasalho da casa a suffocadores dos germens de altruismo que porventura brotem do coração e visceras do homem, e para combater tão perniclosos effeitos ao bem estar da humanidade e sua futura salvação, hemos RESOLVIDO, ACCORDADO, DECIDIDO e ASSENTADO NOS UNIR PELO PRESENTE PACTO, ao qual damos a SOLEMNE FORMA DE CONTRACTO, com todas as FORMALIDADES EXTRA-JUDICIAES, af im de produzir TODOS OS SEUS EFFEITOS de OBEIGATORIEDADE MORAL - MATERIaL,para nos entregarmos á consecução dośs seguintes fins que exigem trabalhos de tal natureza que sem serem HERCULEOS não deixam de ser no entanto de ser INGENTES: 

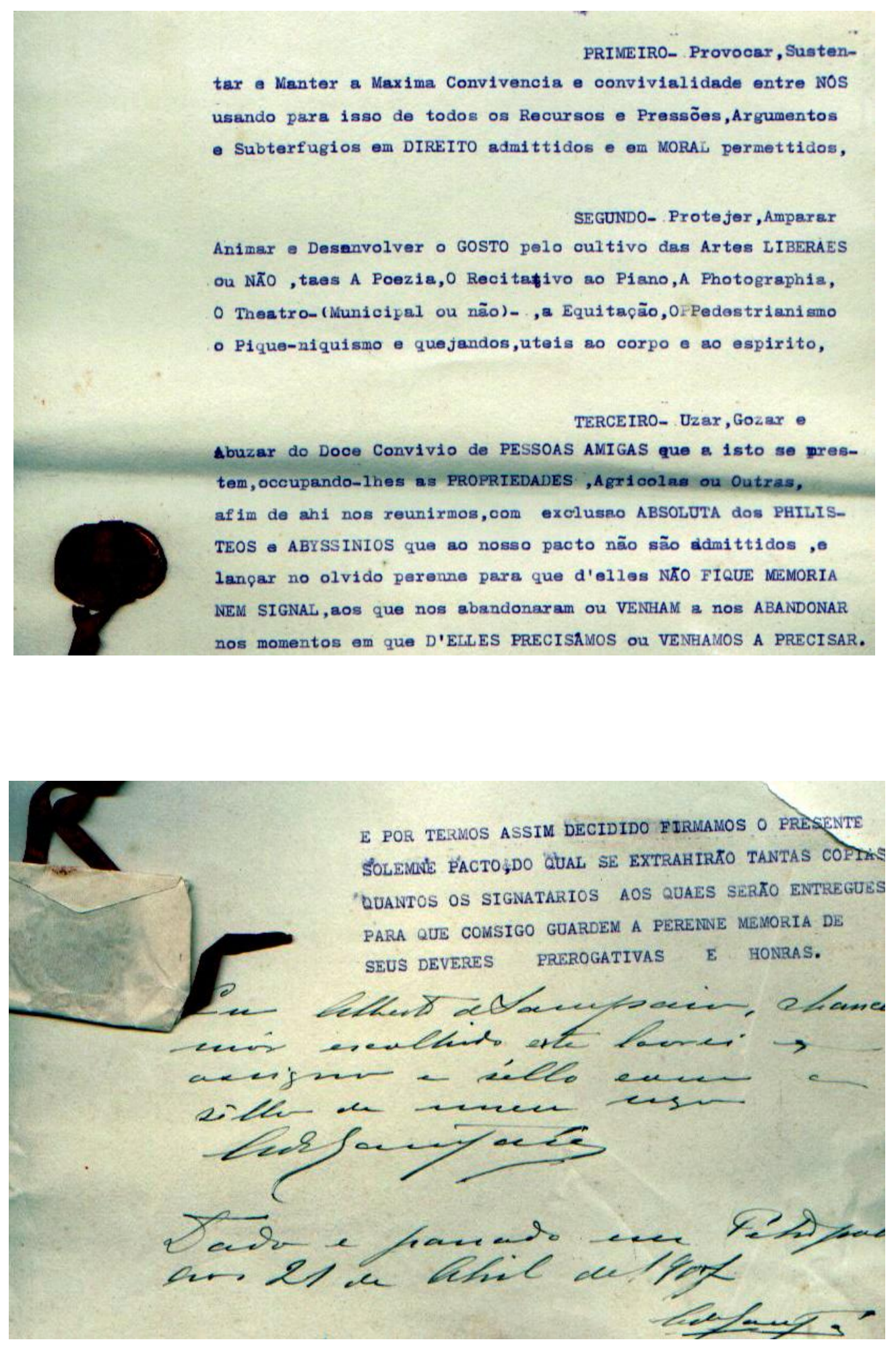

Anexo 1. Texto redigido por Alberto de Sampaio, de maneira irreverente, que trata da formação de um suposto clube em Petrópolis. 


\section{BIBLIOGRAFIA}

ABREU, Maurício de A. A Evolução Urbana do Rio de Janeiro, $2^{\text {a }}$ ed., Rio de Janeiro: Iplanrio/Zahar,1988.

ADAMS, Gavin. A mirada estereoscópica e a sua expressão no Brasil. Tese de Doutorado, Comunicação Estética do Audio Visual Escola de Comunicações e Artes da Universidade de São Paulo, 2004.

AGASSIZ, Luiz; AGASSIZ, Elisabeth Cary. Viagem ao Brasil, 1856-1866. Belo Horizonte: EDUSP/Livraria Itatiaia Editora, 1975.

ALENCASTRO, Luís Felipe de (org.). "Introdução. Modelos da história e da historiografia Imperial" e "Vida privada e ordem privada no Império". In: História da vida privada no Brasil, vol. 2. São Paulo: Companhia das Letras, 1997.

AMBROZIO, Júlio César Gabrich. O presente e o passado no processo urbano da cidade de Petrópolis. Uma história territorial. Tese de Doutorado, Faculdade de Filosofia, Letras e Ciências Humanas, Universidade de São Paulo, 2008.

ANDREWS, Malcolm. Landscape and western art. Oxford and New York: Oxford University Press, 1999.

BAECQUE, Antoine de. "Telas - O corpo no cinema”. In: CORBIN, Alain (ed.). História do Corpo: as mutações do olhar. Petrópolis: VOZES, 2008.

BARBOSA, Rui. O desenho e a arte industrial. Rio de Janeiro: Gráfica Portinho Ltda., 1982.

"Reforma do ensino secundário e superior". In: Obras Completas de Rui Barbosa. Edição comemorativa do $1^{\circ}$ centenário dos pareceres apresentados na Câmara do Império em 1882. Rio de Janeiro: MEC, 1942.

BERGER, Paulo e Eneida. História dos bairros: Copacabana. Rio de Janeiro: Departamento de História do Distrito Federal, 1959.

BIELINSKI, Alba Carneiro. Liceu de Artes e Ofícios do Rio de Janeiro - dos pressupostos aos reflexos de sua criação - de 1856 a 1900. Dissertação de Mestrado em História Crítica da Arte do Programa de Pós-Graduação em Artes Visuais da Escola de Belas Artes da Universidade Federal do Rio de Janeiro, 2003.

BOURDIEU, Pierre. Un Art Moyen, essai sur les usages sociaux de la photographie. Paris: Minuit, 1965.

.; BOURDIEU, Marie-Claire. "O camponês e a fotografia". Revista Sociologia Política. Curitiba, n. 26, jun. 2006, p. 31-39.

. A economia das trocas simbólicas, $5^{\text {a }}$ edição. São Paulo: Ed. perspectiva, 2001.

BORGES, Maria Elisa Linhares. "Representações do Brasil Moderno para ler, ver e ouvir nos circuito dos Museus Commerciais Europeus, 1906 a 1908”. História, São Paulo, v. 26, n.2, 2007, p. 92-117. 
BURGI, Sérgio. "Arte e empreendimento. O estabelecimento fotográfico de Georges Leuzinger (1865-1875)". In: Cadernos de Fotografia Brasileira, Georges Leuzinger, Instituto Moreira Salles, 2006.

CARVALHO,Vânia Carneiro de. "As representações da natureza na pintura e na fotografia brasileiras do século XIX”. In: Fotografia: usos e funções no século XIX, $2^{\mathrm{a}}$ ed. São Paulo: Edusp, 1998, p. 199-232.

Gênero e Artefato: o sistema doméstico na perspectiva da cultura material- São Paulo, 1870-1920. São Paulo: EDUSP/ FAPESP, 2008.

CAPELLARO, Jorge J. V; FERREIRA, Paulo Roberto. Verdades sobre o início do cinema no Brasil. Rio de Janeiro: FUNARTE, 1996.

CHALFEN, Richard. Snapshots versions of life. Ohio: Bowling Green State Univerty Popular Press, 1987.

CHIARELLI, Tadeu. "Gonzaga Duque: A moldura e o quadro da arte brasileira". In: DUQUE, Gonzaga. A arte brasileira. Campinas: Mercado das Letras, 1995, p. 11-42.

COSTA, HELOUISE. Pictorialismo e imprensa: o caso da revista O Cruzeiro (1928-1932). In: Fotografia: usos e funções no século XIX, 2a ed. São Paulo: Edusp, 1998, p. 261-262.

COVAS, Eduardo Alves. O olhar fotográfico de Francisco Brandão. Dissertação de mestrado em Multimeios do Instituto de Artes, da Universidade Estadual de Campinas, 2005.

CORBIN, Alan. "O segredo do indivíduo". In: PERROT, Michelle (org.). História da vida privada 4: da Revolução Francesa à Primeira Guerra. São Paulo: Companhia das Letras, 2003, p.413-502.

L'Avènement des loisirs, 1850-1860. Paris: Flammarion, 1995.

D’AVILLA, Cristiane. "A cidade - espelho na imprensa: representações de Petrópolis em João do Rio". Fora do Lugar- Literatura e Cultura. Disponível em: http://www.foradolugar.com/index.php?option=com_content\&task=view\&id=14\&Itemid=1. Acesso em: 31 de outubro de 2009.

"A cidade letrada". In: Fantasia na Serra: Representações de Petrópolis na mídia impressa. Dissertação de Mestrado. Departamento de Comunicação Social, Pontifícia Universidade Católica do Rio de Janeiro, 2005, p. 51-74.

DUQUE, Gonzaga. A arte brasileira. Campinas: Mercado das Letras, 1995.

DUNLOP, Charles. Petrópolis Antigamente. Rio de Janeiro: ERCA - Editora e Gráfica Ltda, 1985.

GERODETTI, João Emílio; CORNEJO, Carlos. As ferrovias do Brasil nos cartões postais e álbuns de lembranças. São Paulo: Solaris Edições Culturais, 2005.

GERSON, Brasil. História das Ruas do Rio. Rio de Janeiro: Lacerda Ed., 2000. 
GRETTON, Tom. "European Illustrated Weekly Magazines, c. 1850-1900. A model and a Counter-Model for the work of José Guadalupe Posada". Annales del instituto de investigaciones estéticas, Universidad Nacional Autónoma de México, nº 70, 1997, p. 99-125.

GONÇALVES, João Felipe. Rui Barbosa: pondo as idéias no lugar. Rio de Janeiro: Editora FGV, 2000.

GOMES, Paulo Emílio Salles. A expressão social dos filmes documentais no cinema mudo brasileiro (1898-1930). In: CALIL, Carlos Augusto;MACHADO, Maria Tereza (Org.). Paulo Emílio - Um intelectual na linha de frente. Rio de Janeiro / São Paulo: Embrafilme / Brasiliense, 1986. p. 323-330.

Cinema: Trajetória no subdesenvolvimento. São Paulo: Paz e Terra, 1996

GONZAGA, Alice. "Parisiense: cinema na Avenida Central". Filme Cultura. Rio de Janeiro, $\mathrm{n}^{\circ}$ 47, 1986.

GUNNING, Tom. "The whole world within Reach: Travel Images without borders". In: RUOFF, Jeffrey (ed). Virtual Voyages: cinema and travel. Durham and London: Duke University Press, 2006, p. 25-41.

. "New Thresholds of Vision: instantaneous Photography and the Early Cinema of the Lumière Company". In: SMITH, Terry, (ed.) Impossible Presence: Surface and Screen in the Photogenic Era. Chicago: University of Chicago Press, co-published with Power Publications Sydney, 2001, p 71-99.

GUNTHERT, André. "L'institution du photographique. Le roman de la Société héliographique", Études photographiques, n 12, novembre 2002, p. 37-63.

"Naissance de la Société française de photographie", L'Utopie photographique (cat. exp.), Paris, Le Point du jour, 2004, p. 14-24.

HARDMAN, Francisco Foot. Trem-fantasma a ferrovia Madeira-Mamoré e a modernidade na selva. São Paulo: Companhia das Letras, 2005.

HIRSCH, Marianne (ed.). The Familial Gaze. Hanover and London: University Press of New England, 1999.

HOLLAND, Patricia. "Sweet it is to scan", personal photographs and popular photography. In: WELLS, Liz (ed.). Photography: a critical introdution. London and New York: Routledge, 1998, p. 119-164.

HUIZINGA, Johan. Homo Ludens: o jogo como elemento da cultura. São Paulo: Perspectiva, 2007.

IPANEMA, Marcello e Cybelle de. “A Imprensa em Petrópolis". Revista do Instituto Histórico de Petrópolis, 1989, p. 27-56.

JOSCHKE, Christian. "Aux origines des usages sociaux de la photographie. La photographie amateur en Allemangne entre 1890 et 1910". Actes de la recherche en sciences sociales 2004/4, 154, p.53-65. 
.Les yeux de la nation: photographie amateur et société dans l'Allemagne de Guillaume II. Thèse de Doctorat. École des Hautes Études en Sciences Sociales/Universität Mannheim, 2005.

KIRBY, Lynne. Parallel Tracks. Durham, N.C.: Duke University Press, 1997.

KLUMB, Revert Henrique. "Doze horas de diligência: guia do viajante de Petrópolis a Juiz de Fora". In: Anuário do Museu Imperial. Edição Comemorativa, Petrópolis, Museu Imperial, 1995.

KOSSOY, Boris. Origens e expansão da fotografia no Brasil - século XIX. Rio de Janeiro: Funarte, 1980.

. Dicionário histórico-fotográfico brasileiro: fotógrafos e ofício da fotografia no Brasil (1833-1910). São Paulo: Instituto Moreira Salles, 2002.

LEITE, Miriam Moreira. Retratos de família: leitura da fotografia histórica. São Paulo: EDUSP, 1993.

"Fotografia e História". Revista Ciência Hoje, fevereiro de 1988, p. 24-33.

LEVINE, Bárbara; JENSEN, Kirsten. Around the world The Grand Tour in photo albums.

Princeton: Princeton Architectural Press, 2007.

LEVY, Carlos Roberto Maciel. Karl Ernest Papf, 1833-1910. Rio de Janeiro: Pinakotheke, 1980.

LAGO, Pedro e Bia Correa do. Coleção Princesa Isabel: fotografia do século XIX. Rio de Janeiro: Capivara Editora, 2008.

LAGO, Bia Correa. Visões do Brasil: Augusto Sthal, obra completa em Pernambuco e Rio de Janeiro. Rio de Janeiro: 2001.

LIMA; Solange Ferraz de. "O circuito social da fotografia: estudo de caso - II". In: Fotografia: usos e funções no século XIX, $2^{\mathrm{a}}$ ed. São Paulo: Edusp, 1998, p. 79-82.

Ornamento e Cidade: ferro, estuque e pintura mural em São Paulo, 1870-1930. Tese de Doutorado, Faculdade de Filosofia Letras e Ciências Humanas. Programa de Pós-Graduação em História Social, 2001.

MARQUESE, Rafael de Bivar. A paisagem da cafeicultura na crise da escravidão: as pinturas de Nicolau Facchinetti e Georg Grimm. Revista do IEB, n 44, fev 2007, p. 55-76.

MAUAD, Ana Maria. Sob o signo da imagem: A produção da fotografia e o controle dos códigos de representação social da classe dominante, no Rio de Janeiro, na primeira metade do século XX. Tese de Doutorado em História na Universidade Federal Fluminense, 1990.

"Imagem e auto-imagem do Segundo Reinado". In: ALENCASTRO, Luis Felipe de (org.). História da vida privada no Brasil, vol. 2. São Paulo: Companhia das Letras, 2001, p. 181-232. 
. "Na mira do olhar: um exercício de análise da fotografia nas revistas ilustradas cariocas, na primeira metade do século XX". Anais do museu paulista, jun 2005, vol.13, n.1, p.133-174.

Poses e Flagrantes: Ensaios Sobre Historia e Fotografias, Niterói: EDUFF, 2008.

MELLO, Maria Teresa Bandeira de. Arte e fotografia: o movimento pictorialista no Brasil. Rio de Janeiro: Funarte, 1998.

MENDES, Ricardo. "Descobrindo a fotografia nos manuais: América (1840-1880)". In: Fotografia: usos e funções no século XIX, $2^{\mathrm{a}}$ ed. São Paulo: Edusp, 1998, p.83-130.

FotoPlus, 1996.

. Fotografia e Modernismo: um breve ensaio das idéias fora do lugar. São Paulo:

Páginas Negras N.O37, Eunápio Deiró: comentários sobre arte e fotografia no Brasil de 1904. Disponível em: http://www.fotoplus.com/fpb/fpb037/b037a.htm. Acesso em: julho de 2009.

MENESES, Ulpiano T. Bezerra de. "Fontes visuais, cultura visual. Balanço provisório, propostas cautelares". Revista Brasileira de História (São Paulo), vol. 23, nº 45, 2003, p. 11-36.

MOORE, Kevin. "History amateur photography". The Oxford Companion to the Photograph. Oxford University Press, 2005. Disponível em: http://www.answers.com/topic/history-amateurphotography. Acesso em: 15 outubro de 2007.

MORETTIN, Eduardo Victorio. "Dimensões históricas do documentário brasileiro no período silencioso". Revista Brasileira de História. São Paulo, 2005, p. 125-152.

MOURA, Carlos Eugênio Marcondes de (Org.). Retratos quase inocentes. São Paulo: Nobel, 1983.

MOURA, Roberto. "A bela época (primórdios-1912), cinema carioca (1912-1930)". In: RAMOS, Fernão, História do Cinema Brasileiro. São Paulo: Arte, 1990.

MUAZE, Mariana. As memórias da viscondessa: família e poder no Brasil Império. Rio de Janeiro: Jorge Zahar Ed., 2008.

NEWHALL, Beaumont. The History of Photography, from 1839 to the present. New York: Museum of Modern Art, 1982.

NEEDELL, Jeffrey D. Belle Époque tropical: sociedade e cultura de elite no Rio de Janeiro na virada do século. São Paulo: Companhia das Letras, 1993.

NOVAES, Adriano. "A paisagem da fazenda cafeeira através da iconografia do século XIX". Disponível em: http://www.institutocidadeviva.org.br/inventarios/sistema/wpcontent/uploads/2009/11/25_adriano-novaes.pdf. Acesso em: dezembro de 2009.

"Inventário das Fazendas do Vale do Paraíba Fluminense, Instituto Estadual do Patrimônio Cultural Secretaria de Estado e Cultura - RJ. Fazenda Chacrinha", 2009, p. 97-113. Disponível em: $\quad$ http://www.institutocidadeviva.org.br/inventarios/sistema/wpcontent/uploads/2009/11/6 faz-chacrinha.pdf. Acesso em: janeiro de 2010.

O BRASIL DE MARC FERREZ. Rio de Janeiro: Instituto Moreira Salles, 2009. 
ORWELL, Miles. The real thing: imitation and authenticity in american culture, 1880-1940. Chapel Hill and London: University of North, Carolina Press, 1989.

PEIXOTO, Clarice Ehlers. «Les Archives de la Planète: imagens da coleção de Albert Kahn». Cadernos de antropologia e imagem, 8 acervos de imagens, 1999, p. 117-132.

PEREIRA, Adriana Maria Martins. Lentes da memória: a fotografia amadora e o Rio de Janeiro de Alberto de Sampaio (1888-1930). Dissertação de Mestrado no Programa de PósGraduação em Memória Social na Universidade Federal do Estado do Rio de Janeiro, 2004.

. "O lazer no Rio de Janeiro, visto pelo fotógrafo amador Alberto de Sampaio" (19001910). Revista Urbana, Dossiê: Cidade, Imagem, História e Interdisciplinaridade, ano 2, no 2 , 2007.Disponível em: http://www.ifch.unicamp.br/ciec/revista/artigos2/\%5B09\%5DURBANA2_PEREIRA.pdf

PEREIRA, Sônia Gomes. "Relatório final para solicitação de renovação de bolsa de fixação de pesquisador -FAPERJ". Pintura de paisagem, modernidade e o meio artístico carioca no final do século XIX. Reflexões sobre Antônio Parreiras (1860-1937), Baptista da Costa (1865-1926) e Eliseu Visconti (1866-1944), janeiro de 2003.

PERROT, Michelle. «Maneiras de Morar». In: PERROT, Michelle (Org.). História da vida privada, 4: da Revolução Francesa à Primeira Guerra. São Paulo: Companhia das Letras, 1991.

PEIXOTO, Afrânio. A Esfinge. São Paulo: Cia. Brasileira de Impressão e Propaganda, 1962.

POIVERT, Michel. "La Photographie Française em 1900. L'échec du pictorialisme". Vingtième Siècle. Revue d'histoire, 72, octobre-decembre 2001, p.17-25.

RIBEIRO, Suzana Barreto. Percursos do olhar da fotografia profissional e amadora de Campinas (1900-1915). Tese de doutorado em História na Universidade Estadual de Campinas, 2003.

Percursos do olhar - Campinas no início do XX. São Paulo: Annablume, 2007.

SALGADO, Marcus Rogério Tavares Sampaio. A vida vertiginosa dos signos: recepção do idioleto decadista na belle époque tropical. Dissertação de Mestrado Programa de PósGraduação em Letras Vernáculas, Faculdade de Letras, Universidade Federal do Rio de Janeiro, 2006.

SALIBA, Elias Thomé. Raízes do Riso: A representação humorística na história brasileira, de Belle Époque aos primeiros tempos do rádio. São Paulo: Companhia das Letras, 2002.

SANTOS, Yolanda Lhullier dos; CALDAS, Pedro Henrique. Francisco Santos pioneiro no cinema do Brasil. Pelotas: Edic , 1995.

SANTOS, Noronha. Meios de transporte no Rio de Janeiro: história e legislação, vol. 1. $2^{\mathrm{a}}$ edição. Rio de Janeiro: Secretaria Municipal de Cultura, 1996.

"Traços Biográficos". Revista do Serviço do Patrimônio Histórico e Artístico Nacional, no. 8, 1944. p. 164 -172. 
SCHWARCZ, Lilia Moritz. As barbas do Imperador: D. Pedro II, um monarca nos trópicos. São Paulo: Companhia das Letras, 1998.

SCHAPOCHINK, Nelson. "Cartões-postais, álbuns de família e ícones de intimidade". In: SEVCENKO, Nicolau (org.). História da vida privada no Brasil 3 - República: da Belle Époque à era do rádio. São Paulo: Companhia das Letras, 1998, p. 423-512.

SEGALA, Lígia. "Itinerância fotográfica e o Brasil pitoresco". TURAZZI, Maria Inês (Org.). Revista do patrimônio Histórico e Artístico Nacional, n. 27, 1998, p.62-87.

SEIBERLING, Grace \& BIOORE, Carolyn. Amateur, photography and the mid-Victorian imagination. Chicago: The University of Chicago Press, 1986.

SERRANO, Eneida. LUNARA. Lunara-Amador 1900, 1979.[Catálogo da exposição].

SEVCENKO, Nicolau (org.). "Prelúdio Republicano, astúcias da ordem e ilusões do progresso" e "A capital irradiante: técnicas, ritmos e ritos do Rio". In: História da vida privada no Brasil 3 - República: da Belle Époque à era do rádio. São Paulo: Companhia das Letras, 1998, p. 7-48; p. 513-619.

Literatura como missão: tensões sociais e criação cultural na Primeira República, $2^{\mathrm{a}}$ edição. São Paulo: Companhia das Letras, 2003.

SOLOMON-GODEAU, Abigail. "Calotypomanie. Guide du gourmet en photographie historique". Etudes photographiques, n ${ }^{\circ}$, novembre 2002, p. 4-36.

SOUZA, Carlos Roberto de. Nossa aventura na tela: a trajetória fascinante do cinema brasileiro da primeira filmagem a "Central do Brasil". São Paulo: Cultura Editores Associados, 1998.

SOUZA, José Inácio de Melo. Imagens do passado: São Paulo e Rio de Janeiro nos primórdios do cinema. São Paulo: Editora Senac, 2004.

SQUEFF, Letícia. "Fundando a paisagem nacional: o urbano e o selvagem no pensamento de Araújo Porto Alegre". In: SALGUEIRO, Heliana Angotti (org.). Paisagem e arte: a invenção da natureza, a evolução do olhar. São Paulo: Comitê Brasileiro de História da Arte, 2000, p. 273-279.

STERNBERGER, Paul Spencer. Between amateur and aesthete: the legitimization of photography as art in America, 1880-1900. Albuquerque: University of New Mexico Press, 2001.

SUSSEKIND, Flora. Cinematógrafo de letras. Literatura, técnica e modernização no Brasil. São Paulo: Companhia das letras, 1987.

TELES, Pedro Carlos da Silva. História da Engenharia no Brasil, Rio de Janeiro: Claveiro 1994.

TURAZZI, Maria Inês. Poses e trejeitos: a fotografia e as exposições na era do espetáculo 1839-1889. Rio de Janeiro: Rocco, 1995. 
As artes do ofício: fotografia e memória da engenharia no século XIX. Tese de Doutorado na Faculdade de Arquitetura e Urbanismo da Universidade de São Paulo, 1997.

"Uma cultura fotográfica". Fotografia, Revista do Patrimônio Histórico e Artístico Nacional, $\mathrm{n}^{\mathrm{o}} 27,1998$, p. 7-15.

. Marc Ferrez: fotografias de um “artista ilustrado”. São Paulo: Cosac \& Naif, 2002.

VALLE, Arthur; DAZZI, Camila "As bellezas naturaes do nosso paiz":o lugar da paisagem na arte brasileira, do Império à República". Concinnitas, ano 10, volume 1, número 14, junho 2009, p.121-133.

VASQUEZ, Pedro Karp. Álbum da Estrada União e Indústria. Rio de Janeiro: Quadratim G., 1998.

Fotógrafos alemães no Brasil do século XIX. São Paulo: Metalivros, 2000.

. A fotografia no Império. Rio de Janeiro: Jorge Zahar, 2002.

. O Brasil na fotografia oitocentista. São Paulo: Metalivros, 2003.

. Nos trilhos do progresso: a ferrovia no Brasil Imperial vista pela fotografia. São Paulo: Metalivros, 2007.

Ferrovia e fotografia no Brasil da Primeira República. São Paulo: Metalivros, 2008.

VIANY, Alex. Introdução ao cinema brasileiro. Rio de Janeiro: Instituto Nacional do Livro, 1959.

VILAÇA, Flávio. Espaço intra-urbano no Brasil. São Paulo: Studio Nobel/ FAPESP/ Lincoln Institute 1998.

WELLS, Liz (ed.). Photography: a critical introdution. London and New York: Routledge, 1998.

WEST, Nancy Martha. Kodak and the Lens of Nostalgia. Charlottesville and London: The University Press of Virginia, 2000.

WIGODER, Meir. "Paul Strand's New York Portraits. Private Eye - Public Space". History of Photography, vol. 27, $\mathrm{n}^{\mathrm{O}}$ 4, winter 2003, p. 349-361.

\section{Demais publicações:}

ARCHER, Major. Memorial, 30 de abril de 1881 [arquivo do Museu Imperial].

FROES, José Kopke. "Curiosidades petropolitanas. Pic-nic em 1902". Jornal Tribuna de Petrópolis, 13/12/1964.

Livro do Centenário (1500-1900). Associação do Quarto Centenário do Descobrimento do Brasil. Rio de Janeiro, Impr. nacional, 1900-1910.

NEVES, Getúlio das. "A indústria nacional”. Revista Brasileira. Rio de Janeiro, São Paulo: Laemmert \& Co. editores, 1895. 
O empreendedor Teixeira Soares, Prefeitura de União da Vitória e Superintendência da Rede Ferroviária Federal, s.d.

VOGEL, H. La photographie et la chimie de la lumière. Paris, Germer Baillière, 1876.

VASCONCELLOS, Francisco de. "Paulo Barbosa da Silva que tanto fez pela fundação de Petrópolis". Jornal Tribuna de Petrópolis, 26/11/2000.

\section{Acesso internet:}

ALVES NETTO, Jeronymo Ferreira. Os verões presidenciais em Petrópolis. Disponível em: http://www.ihp.org.br/ihp/site/. Acesso em: dezembro de 2008.

Brasileiros ilustres em Petrópolis - Conde Afonso Celso. Disponível em: http://www.ihp.org.br/ihp/site/. Acesso em: outubro de 2008.

. Brasileiros ilustres em Petrópolis - Hermes Rodrigues da Fonseca. Disponível em: http://www.ihp.org.br/ihp/site/. Acesso em: outubro de 2008.

. Brasileiros ilustres em Petrópolis - O Visconde de Ouro Preto. Disponível em: http://www.ihp.org.br/ihp/site/. Acesso em: outubro de 2008.

- O Liceu de Artes e Ofícios de Petrópolis. Disponível em: http://www.ihp.org.br/ihp/site/. Acesso em: outubro de 2008.

Early Photography. Sanderson Cameras. Disponível em: http://www.earlyphotography.co.uk/site/sanderson.html. Acesso em: julho de 2009.

Georges Eastman House, Photographic Collections online. Disponível em: http://www.geh.org/fm/lol/htmlsrc/lol92 sum00001.html. Acesso em: agosto de 2008.

LORDEIRO, Manoel de Souza. A presença em Petrópolis, do Major Archer, o precursor da sivilcultura no Brasil. Disponível em: http://www.ihp.org.br/ihp/site/. Acesso em: janeiro de 2008.

SAMPAIO, Eduardo Soares de. João Teixeira Soares. http://www.autores.com.br/200804174058/Relacionamento/Saudade/joao-teixeira-soares.html. Acesso em: dezembro de 2008.

SANTOS, Joaquim Eloy dos. $O$ sindicato do turismo. Disponível em: http://www.ihp.org.br/ihp/site/. Acesso em: setembro de 2008.

Cinema, tradição e Pioneirismo. Disponível em: http://www.ihp.org.br/ihp/site/. Acesso em: janeiro de 2008.

Cinema em Petrópolis, sua história I. Disponível em: http://www.ihp.org.br/ihp/site/. Acesso em: janeiro de 2008

VASCONCELLOS, Francisco de. Petrópolis e sua malograda anexação ao Distrito Federal I. Disponível em: http://www.ihp.org.br/ihp/site. Acesso em: janeiro de 2009. 
A segunda exposição de artes plásticas no Club Petrópolis. Disponível em: http://www.ihp.org.br/ihp/site/. Acesso em: janeiro de 2009.

Who's Who of Victorian Cinema. Cecil Milton Hepworth. Disponível em: http://www.victorian-cinema.net/hepworth.htm. Acesso em: dezembro de 2009.

\section{Revistas e jornais:}

Amateur Work (1890-1895)

Bulletin Belge de Photographie (1899)

Paris-Photographe (1891-1893)

Lectures pour tous (1902-1904)

Le monde moderne (1900-1910)

L'Illustration (1903-1906)

The Graphic (1894-1914)

Fon-Fon! (1907)

Illustração Brasileira (1926)

Revista Brasileira (1895)

Renascença (1904-1908)

Kosmos (1904-1909)

Careta (1904-1912)

Revista da Semana (1905-1914)

Leitura para todos (1905-1914)

Verão em Petrópolis (1902/1903)

Jornal Gazeta de Petrópolis, (1897-1904)

Jornal Tribuna de Petrópolis, (1904-1914)

Jornal Cidade de Petrópolis (1902-1914)

Jornal $O$ mercantil $(1883,1888)$

Jornal O cruzeiro (1908-1913)

\section{Instituições pesquisadas:}

Biblioteca Nacional

Instituto Histórico e Geográfico Brasileiro

Real Gabinete Português de Leitura

Biblioteca de Obras Raras da Escola de Engenharia da UFRJ

Biblioteca de Obras Raras da Escola de Belas Artes da UFRJ

Casa de Rui Barbosa

Biblioteca Municipal Gabriela Mistral (Petrópolis)

Arquivo Histórico de Petrópolis

Museu Imperial de Petrópolis

Museu Mariano Procópio

Instituto de Estudos Brasileiros (USP)

Biblioteca Mario de Andrade

Cinemateca Brasileira

\section{Acervos consultados:}

Acervo pessoal da família Soares de Sampaio.

Acervo da Sociedade Petropolitana de Fotografia (SOPEF). 
UNIVERSIDADE DE SÃO PAULO

FACULDADE DE FILOSOFIA, LETRAS E CIÊNCIAS HUMANAS

DEPARTAMENTO DE HISTÓRIA

PROGRAMA DE PÓS-GRADUAÇÃO EM HISTORIA SOCIAL

ADRIANA MARIA PINHEIRO MARTINS PEREIRA

\section{A cultura amadora na virada do século XIX: a fotografia de Alberto de Sampaio (Petrópolis/Rio de Janeiro, 1888-1914)}

\section{Caderno de Figuras}


UNIVERSIDADE DE SÃO PAULO

FACULDADE DE FILOSOFIA, LETRAS E CIÊNCIAS HUMANAS

DEPARTAMENTO DE HISTÓRIA

PROGRAMA DE PÓS-GRADUAÇÃO EM HISTORIA SOCIAL

\section{A cultura amadora na virada do século XIX: a fotografia de Alberto de Sampaio (Petrópolis/Rio de Janeiro, 1888-1914)}

Adriana Maria Pinheiro Martins Pereira

Tese apresentada ao Programa de Pós-Graduação em História Social do Departamento de História da Faculdade de Filosofia, Letras e Ciências Humanas da Universidade de São Paulo, para a obtenção do título de Doutor em História.

Orientador:

Prof. Dr. Ulpiano Toledo Bezerra de Meneses

V.2

São Paulo

2010 


\section{Caderno de Figuras}

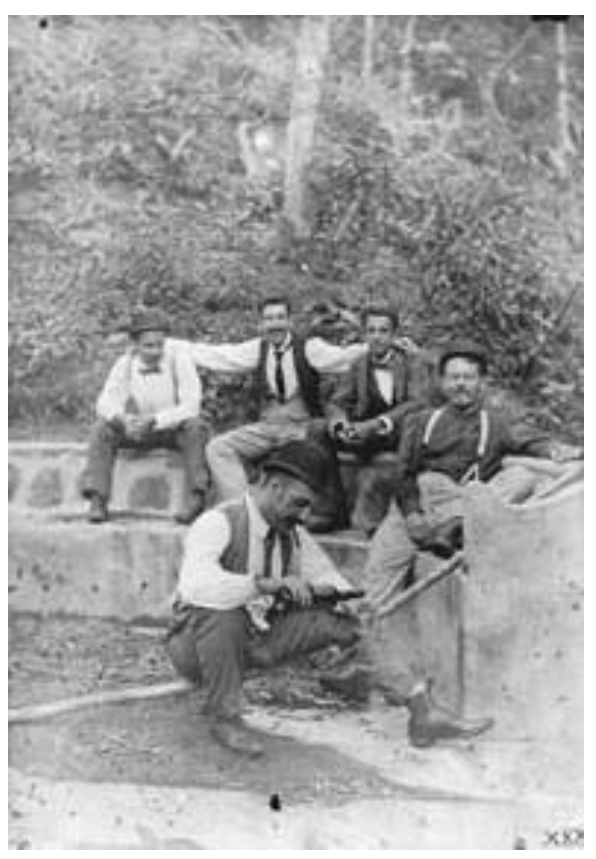

Fig.1. Pic-nic na Gávea, 1888. Negativo em vidro. Gelatina/prata, $12 \times 16 \mathrm{~cm}$. Legenda original.
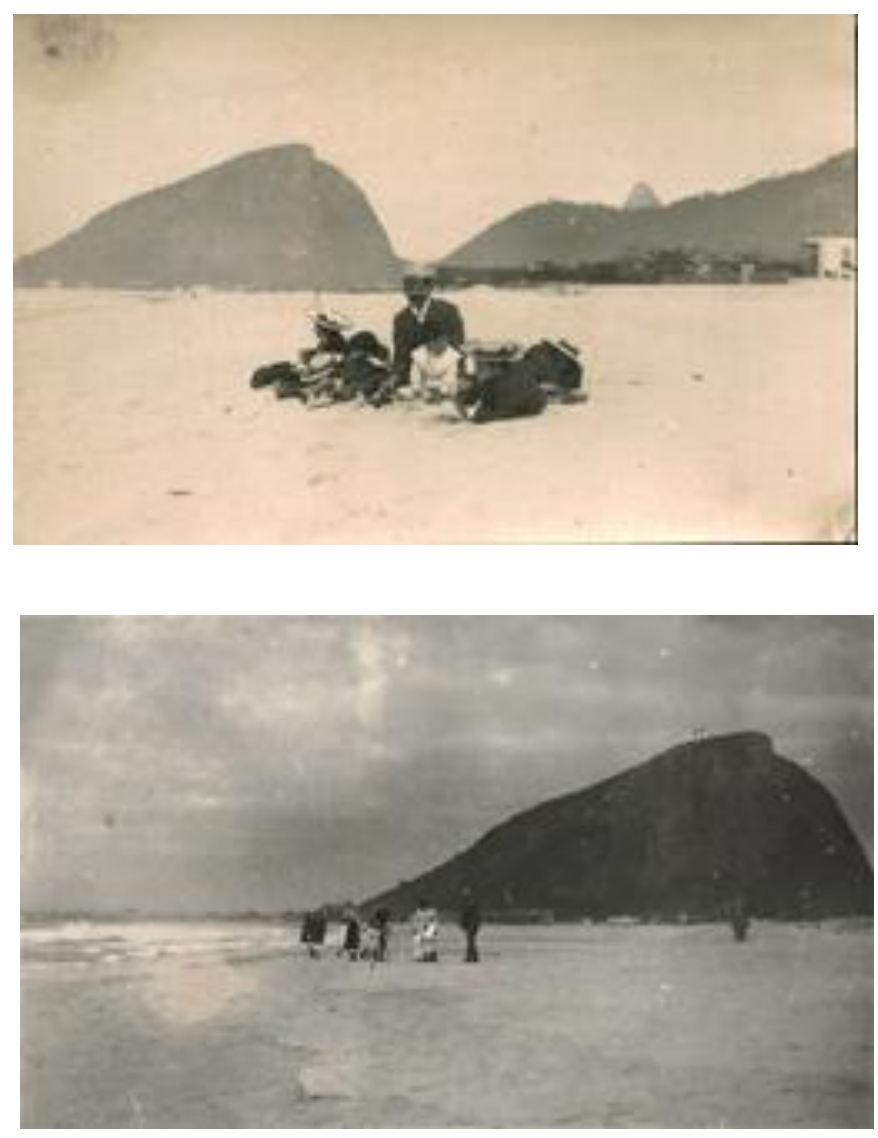

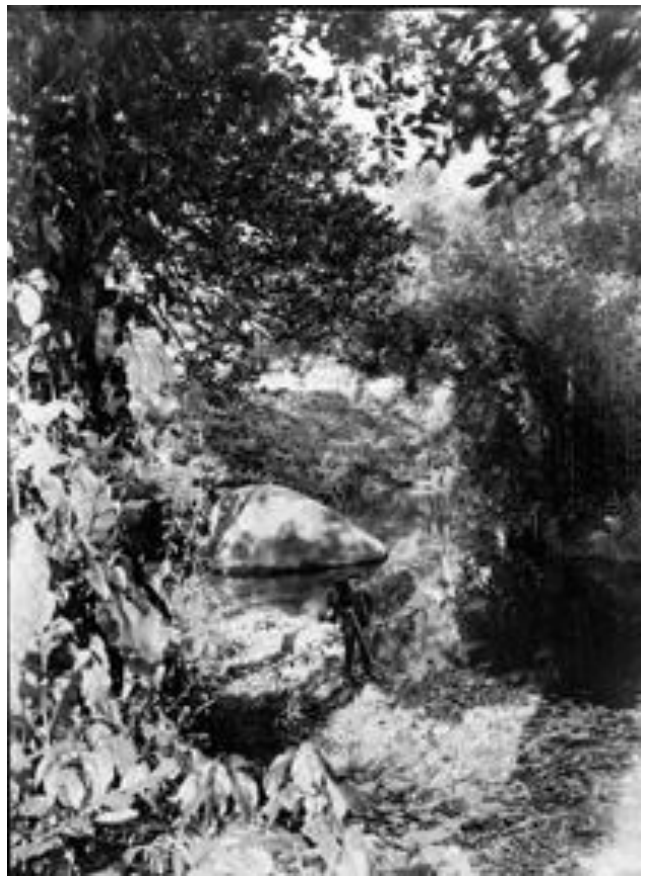

Fig.2. Otávio de Oliveira Castro com a câmera, 1906. Negativo em vidro, Gelatina/prata, 12 x $16 \mathrm{~cm}$. Legenda atribuída.

Fig. 3. Otávio de Oliveira Castro e crianças em Copacabana, 1906. Cópia em papel, negativo em celulóide. Legenda atribuída.
Fig.4. Otávio de Oliveira Castro, empregada e crianças em Copacabana, 1906. Cópia em papel, negativo em celulóide. Legenda atribuída. 


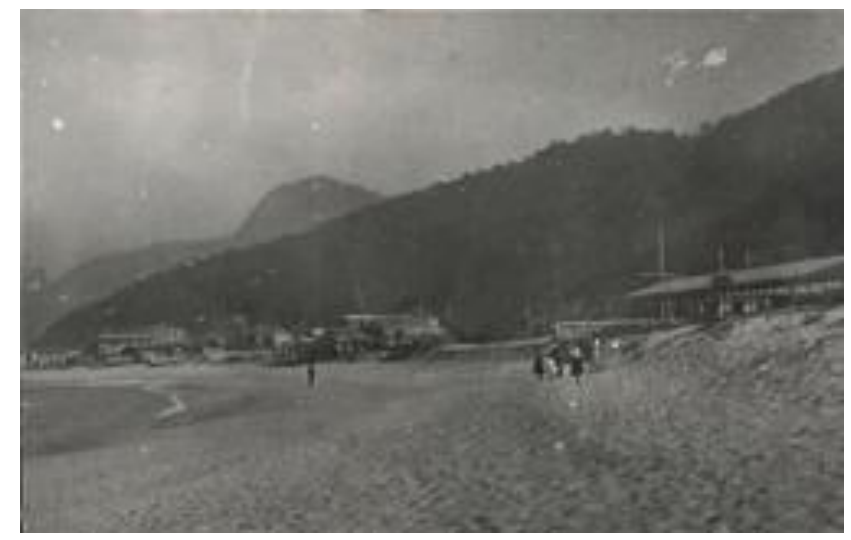

Fig. 5. Praia de Copacabana, 1906. Cópia em papel, negativo em celulóide. Legenda atribuída.

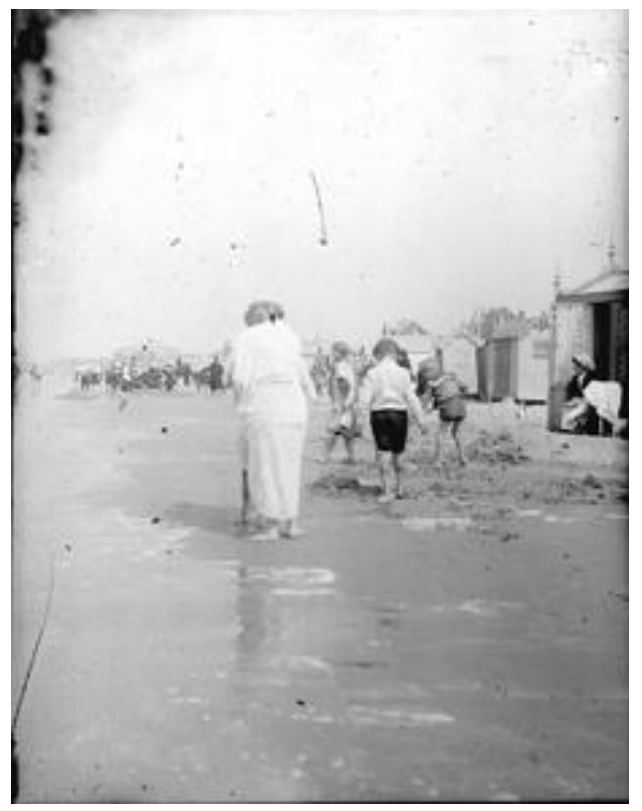

Fig. 6. Praia (Europa), 1913. Negativo em vidro, Gelatina/prata, 10 x 8,5 cm. Legenda atribuída.

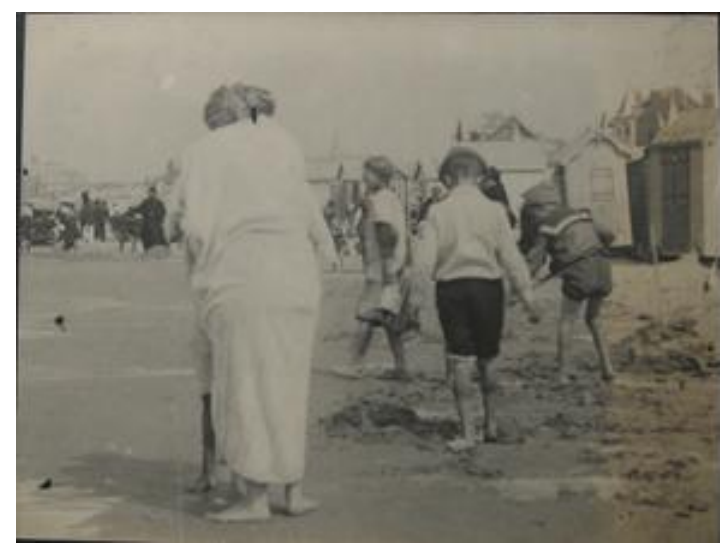

Fig.6.1. Praia (Europa), 1913. Cópia em papel, editada. Legenda atribuída.

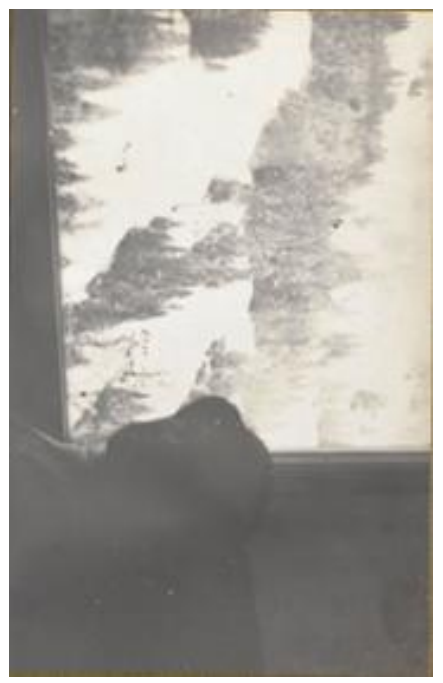

Fig. 7. Photo tomada do wagon do Oberland Bernois em caminho para Chateaux d'oeux - abril de 1913. Cópia em papel, negativo em celulóide. Legenda original. 


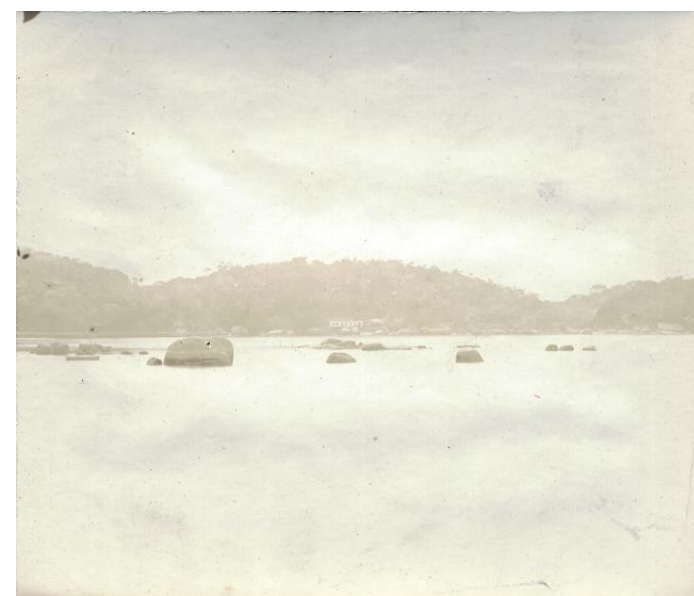

Fig.8. Vista de Paquetá, c. 1890. Cópia em papel. Legenda atribuída.

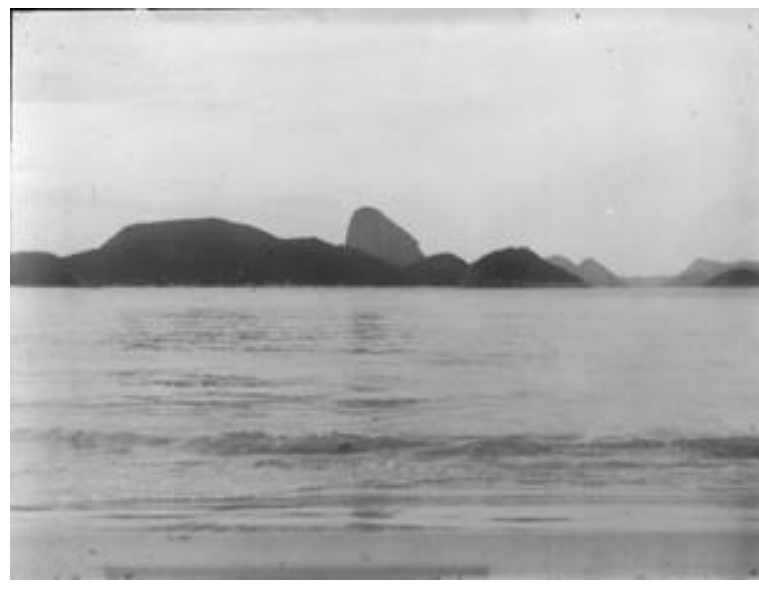

Fig. 9. Vista da Barra (Copacabana). Negativo em vidro. Gelatina/prata, 10 x 8,5 cm. Legenda original.
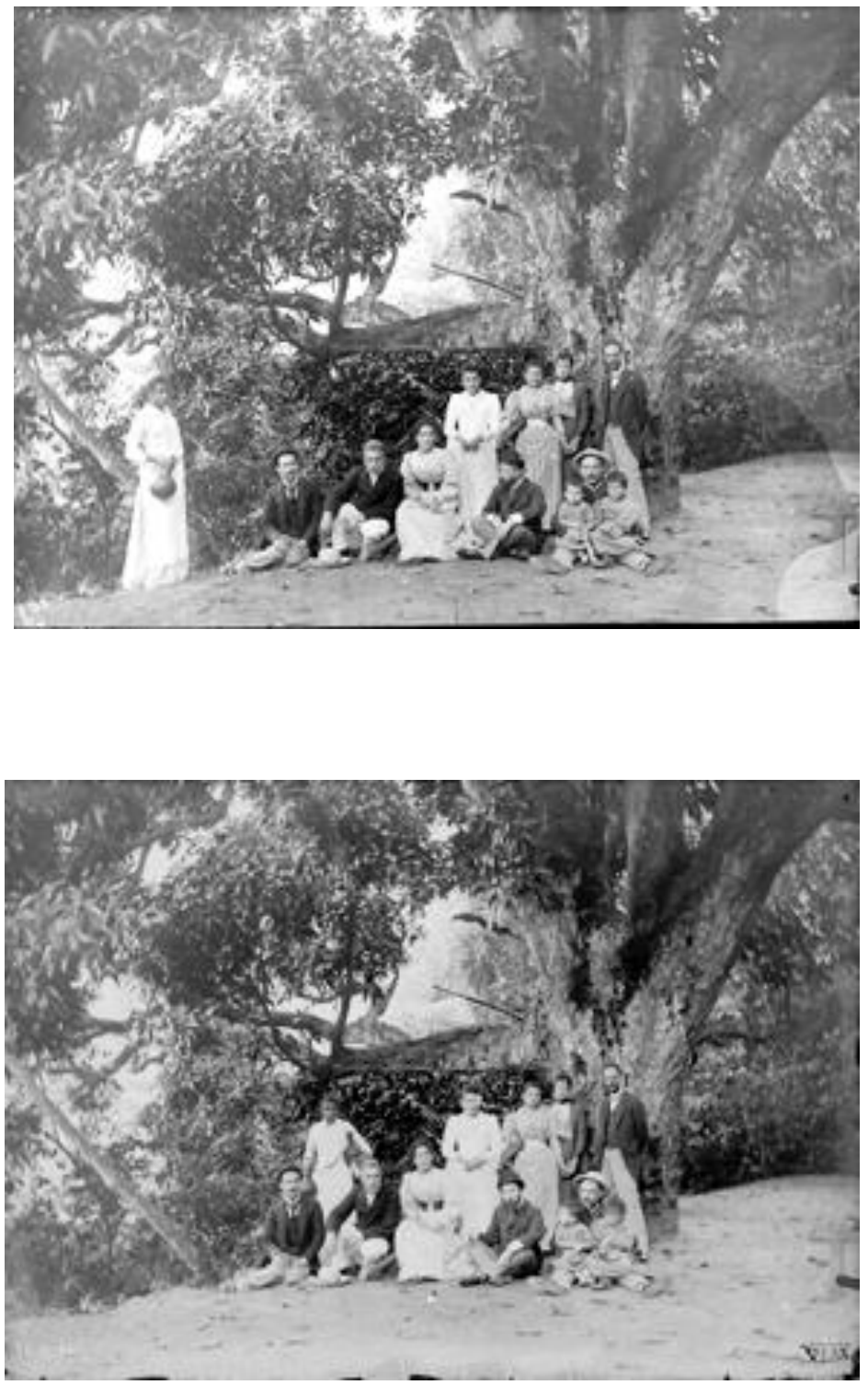

Fig. 10. Grupo na mangueira (Rua do Bispo) setembro,1893. Negativo em vidro. Gelatina/prata, 17,5 x $13 \mathrm{~cm}$. Legenda original.

Fig. 11. Grupo na mangueira (Rua do Bispo) setembro, 1893. Negativo em vidro. Gelatina/prata, 17,5 x $13 \mathrm{~cm}$. Legenda original. 


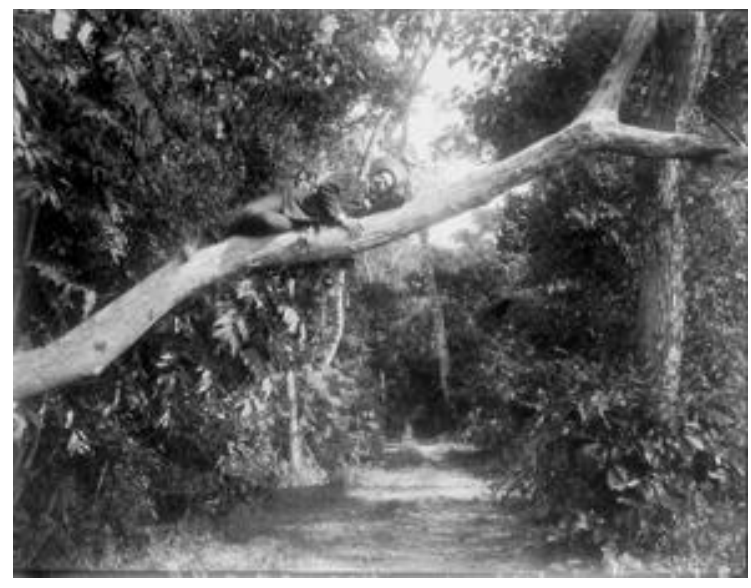

Fig. 12. Otávio na árvore, 1908. Negativo em vidro. Gelatina/prata, 10 x $8,5 \mathrm{~cm}$. Legenda original.

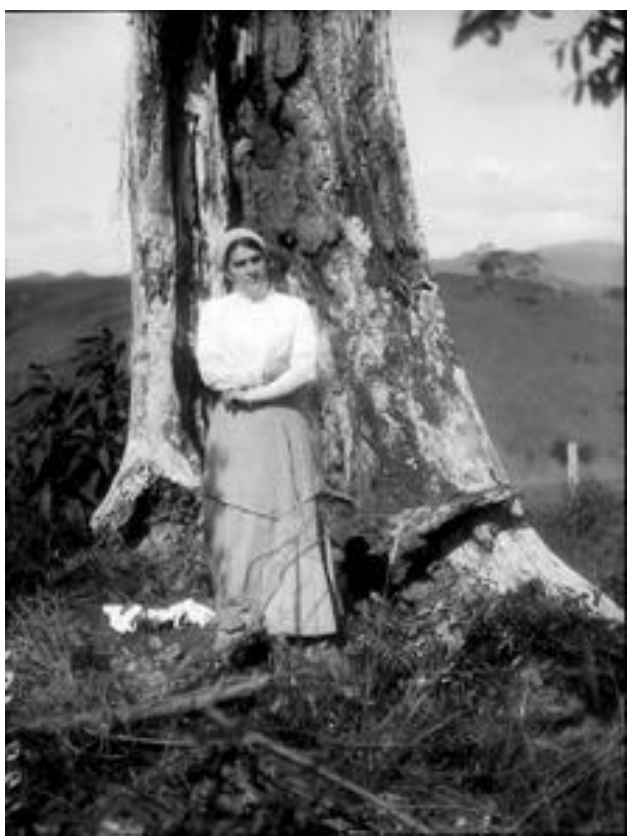

Fig. 14. Cecília junto a árvore, 1911. Negativo em vidro. Gelatina/prata, $10 \mathrm{x}$ $8,5 \mathrm{~cm}$. Legenda original.

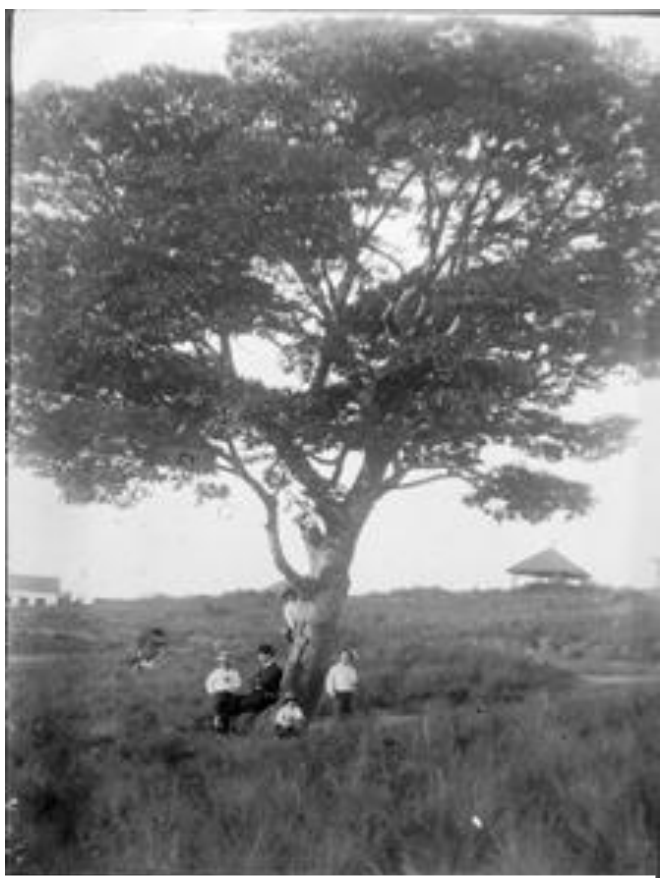

Fig. 13. Otávio e crianças na Figueira de Campanha, 1908. Negativo em vidro. Gelatina/prata, 10 x $8,5 \mathrm{~cm}$. Legenda original.

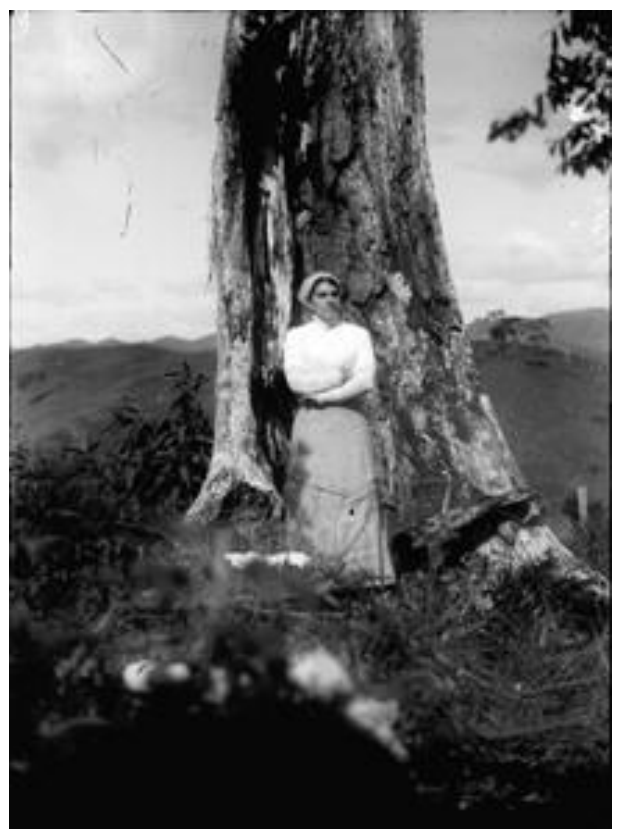

Fig. 15. Cecília junto a árvore, 1911. Negativo em vidro. Gelatina/prata, $10 \mathrm{x}$ $8,5 \mathrm{~cm}$. Legenda original. 


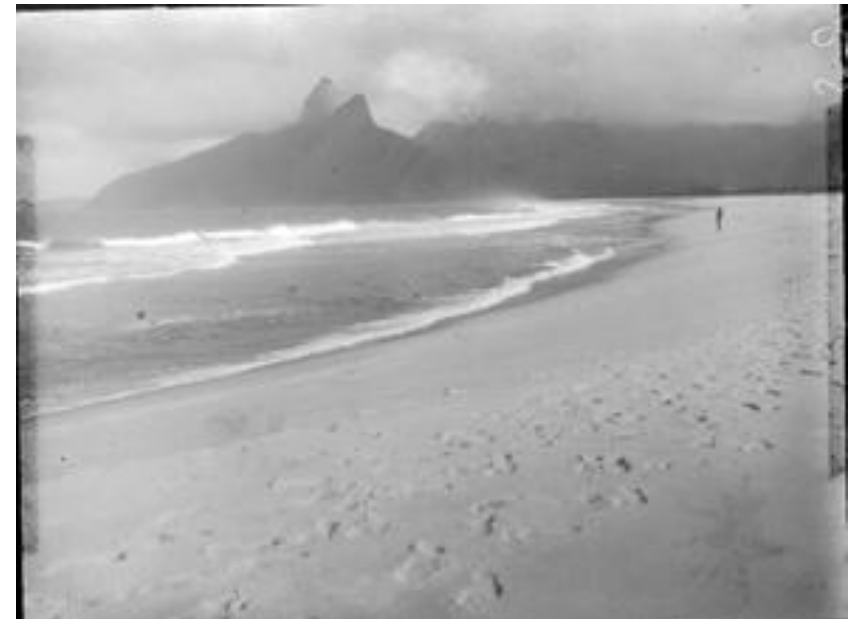

Fig. 16. Ipanema, 1907. Negativo em vidro. Gelatina/prata, 10 x 8,5 cm. Legenda original.

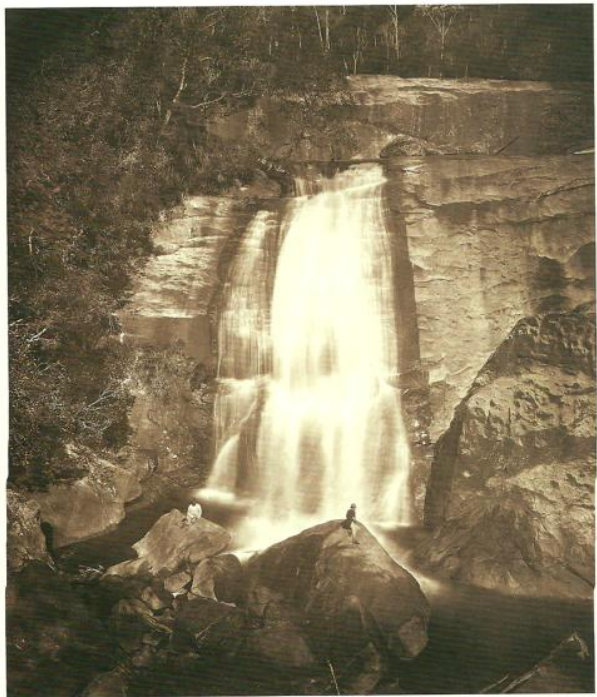

Fig.18. Cascata do Itamarati, Marc Ferrez, c. 1880. Coleção Gilberto Ferrez do Instituto Moreira Salles. O Brasil de Marc Ferrez (2005: 191).

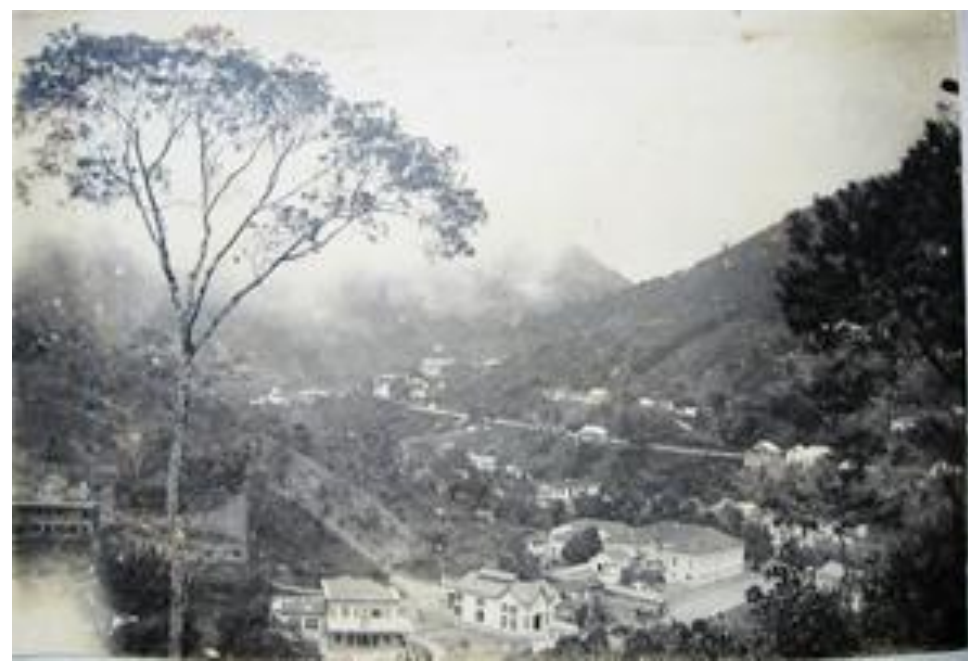

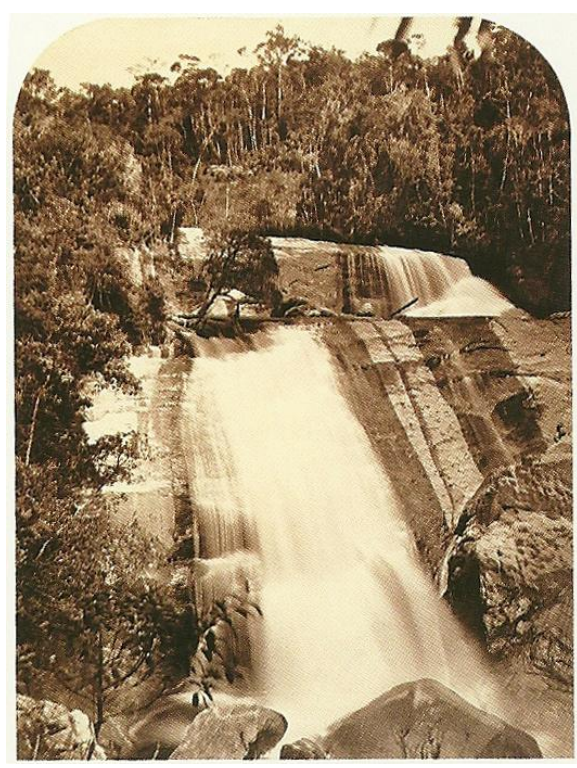

Fig. 17. Cascata do Itamarati, Revert Henrique Klumb, c. 1874. Acervo Museu Imperial (Vasquez, 2003: 147).

Fig. 19. Palatinado visto do morro da Souza Franco, 1895. Cópia em papel. Legenda original. 


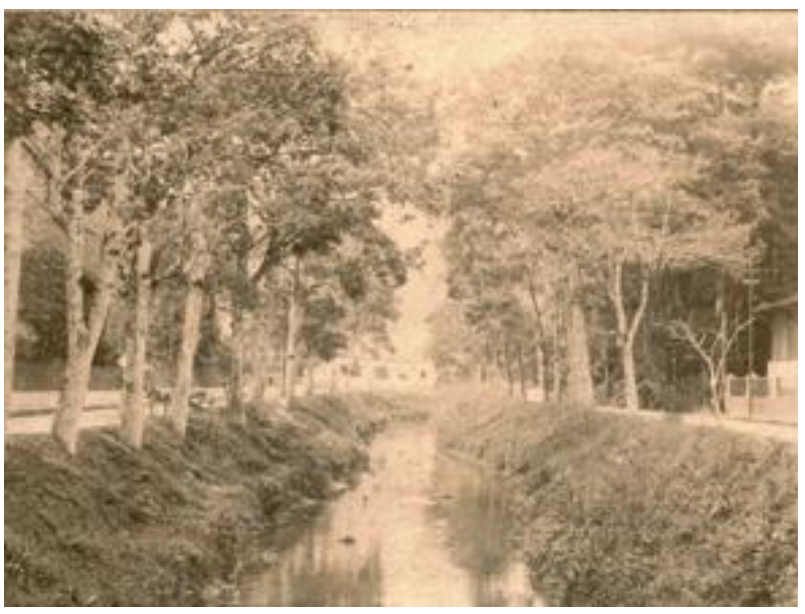

Fig. 20. Canal em Piabanha. Cópia em papel. Legenda original.

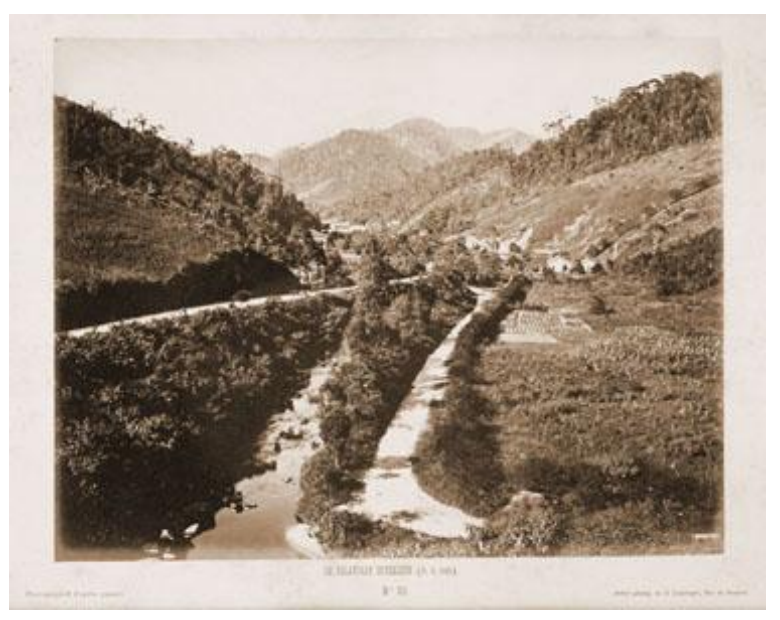

Fig. 22. Le Palatinat inférieur, 1867. Georges Leuzinger. Acervo Museu Imperial.

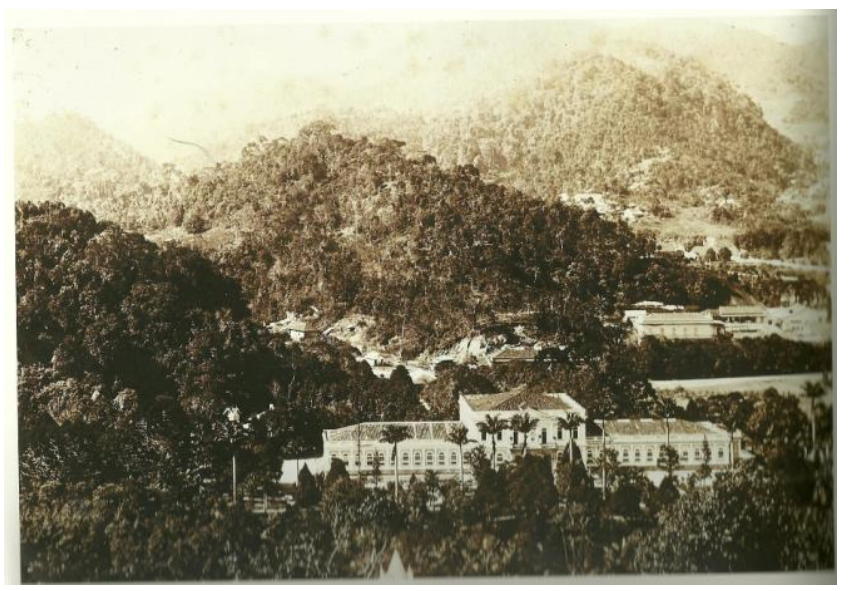

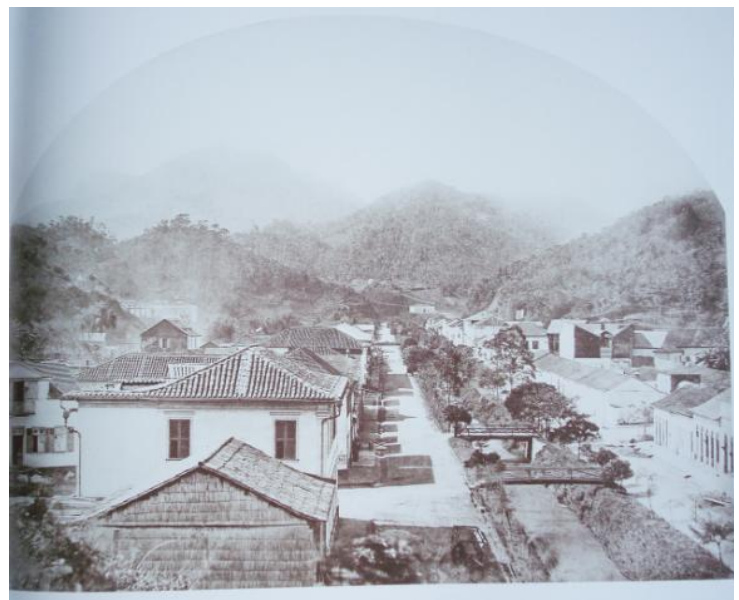

Fig. 21. Rua do Imperador em Petrópolis, c. 1865, Augusto Sthal (Lago, 2001: 205).

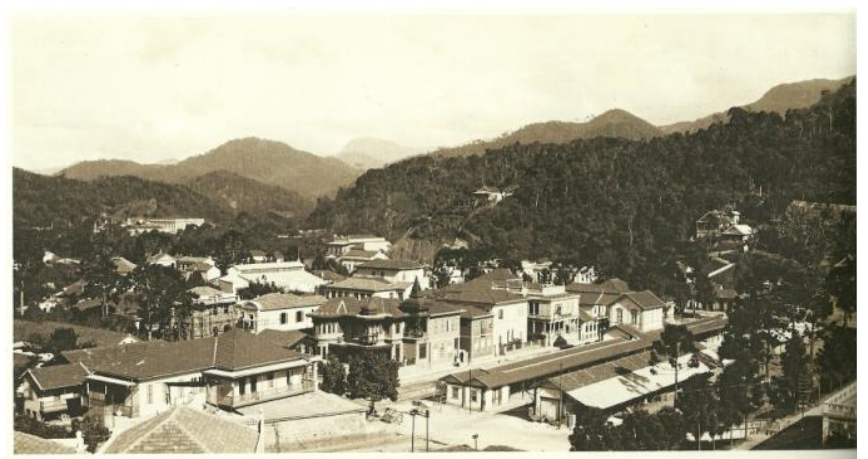

Fig 23. Centro de Petrópolis, c. 1889, Marc Ferrez. Coleção Princesa Isabel (Lago, 2008: 226).

Fig 24. Vista do Palácio Imperial, c. 1885. Marc Ferrez, Coleção Princesa Isabel (Lago, 2008: 170). 


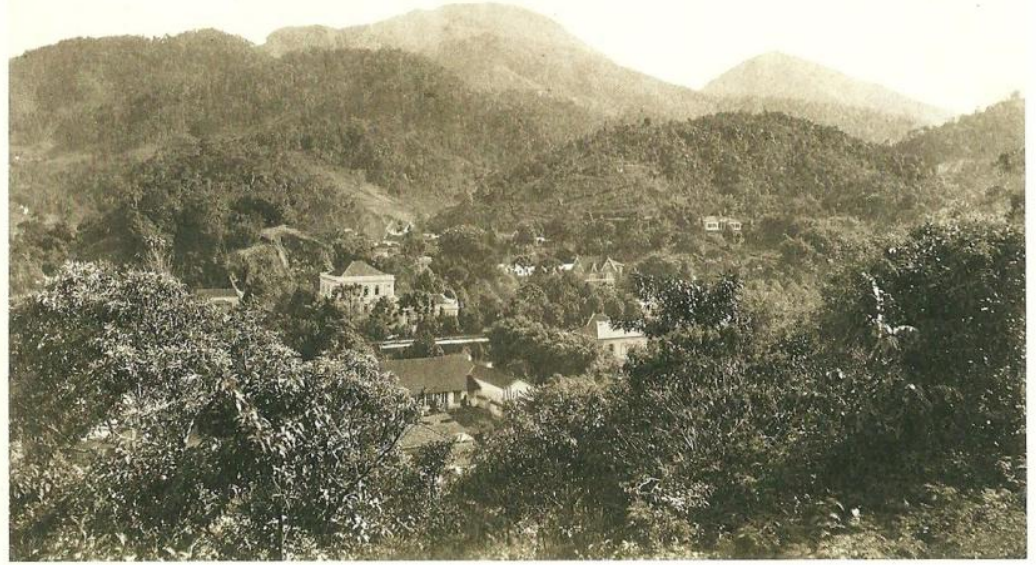

Fig. 25. Vista de Petrópolis, c. 1885, Karl Ernest e Jorge Henrique Papf. Coleção Princesa Isabel (Lago, 2008: 245).

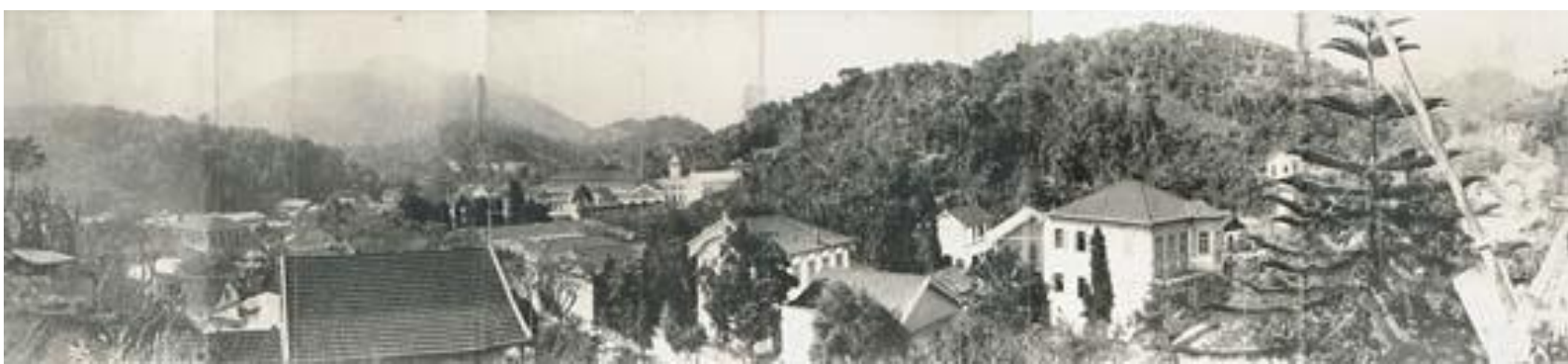

Fig. 26. Panorâmica do centro de Petrópolis, Jorge Henrique Papf. Acervo de Alberto de Sampaio.

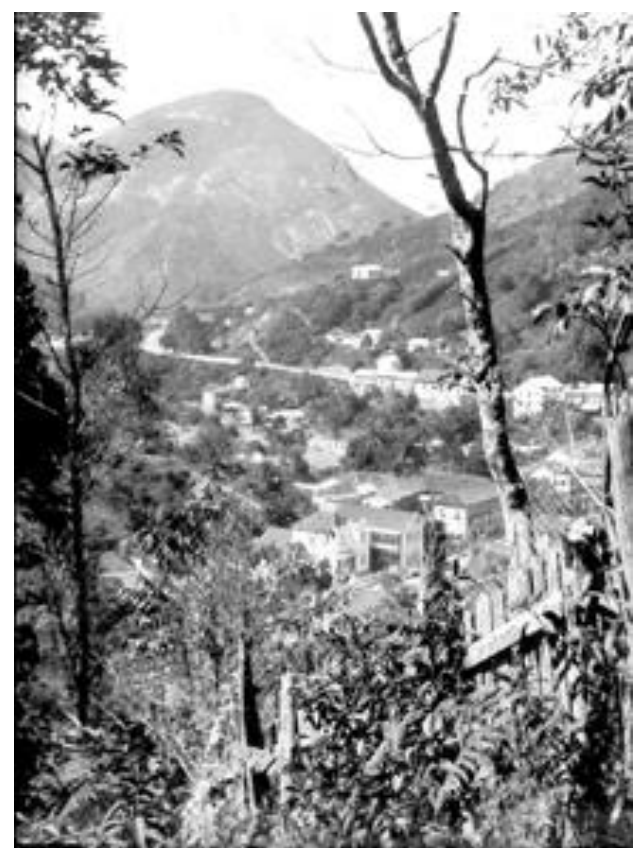

Fig. 27. Palatinado visto do morro da Souza Franco, 1885. Negativo em vidro. Gelatina/prata, 10 x $8,5 \mathrm{~cm}$. Legenda original.

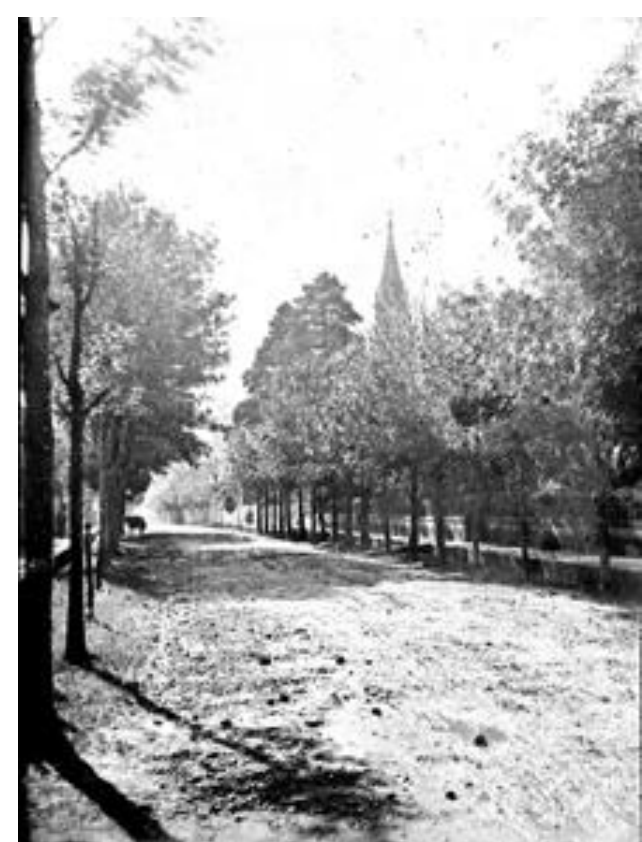

Fig. 28. Rua de Joinville, 1906. Negativo em vidro. Gelatina/prata, 10 x $8,5 \mathrm{~cm}$. Legenda original. 


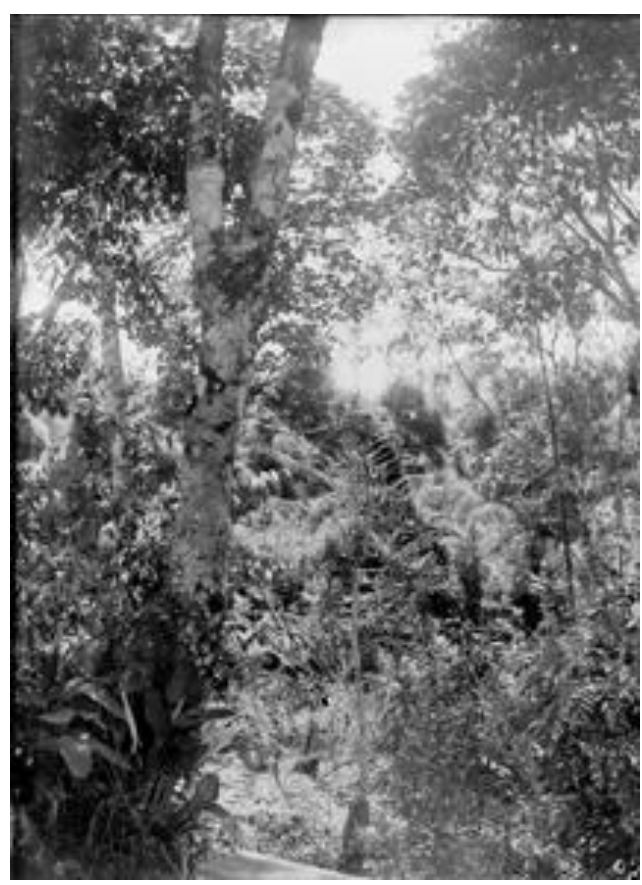

Fig. 29. Matto no morro, 1903. Negativo em vidro. Gelatina/prata, 12 x $16 \mathrm{~cm}$. Legenda original.

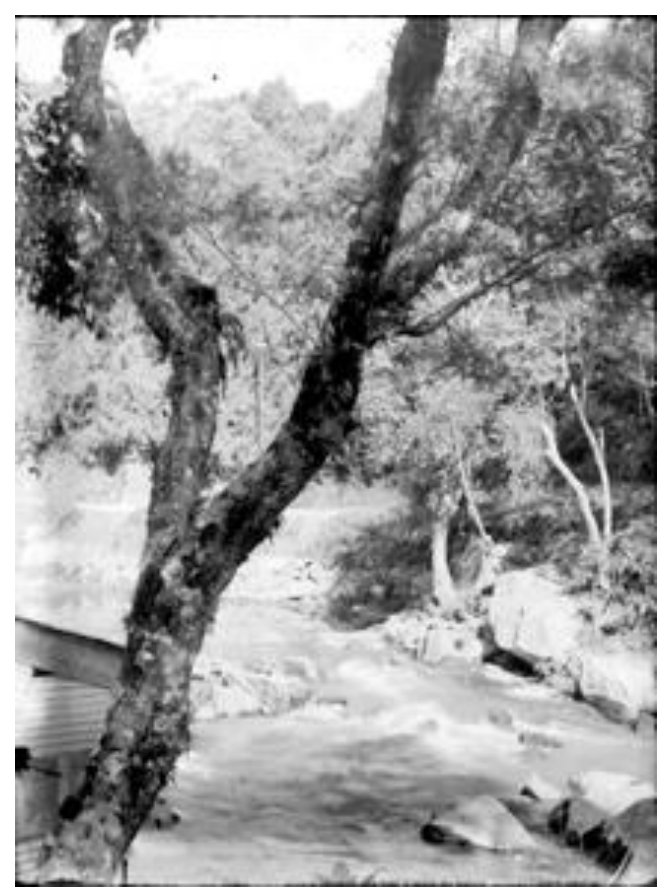

Fig. 31. Rio Piabanha, 1905. Negativo em vidro. Gelatina/prata, 10 x $8,5 \mathrm{~cm}$. Legenda original.

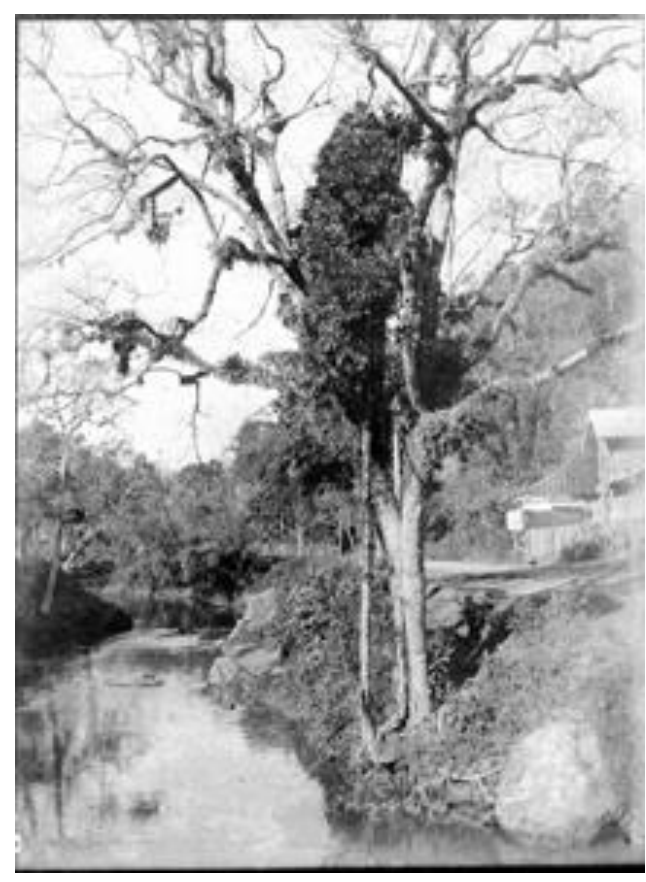

Fig. 30. Árvore no Piabanha, 1905. Negativo em vidro. Gelatina/prata, 10 x 8,5 $\mathrm{cm}$. Legenda original.

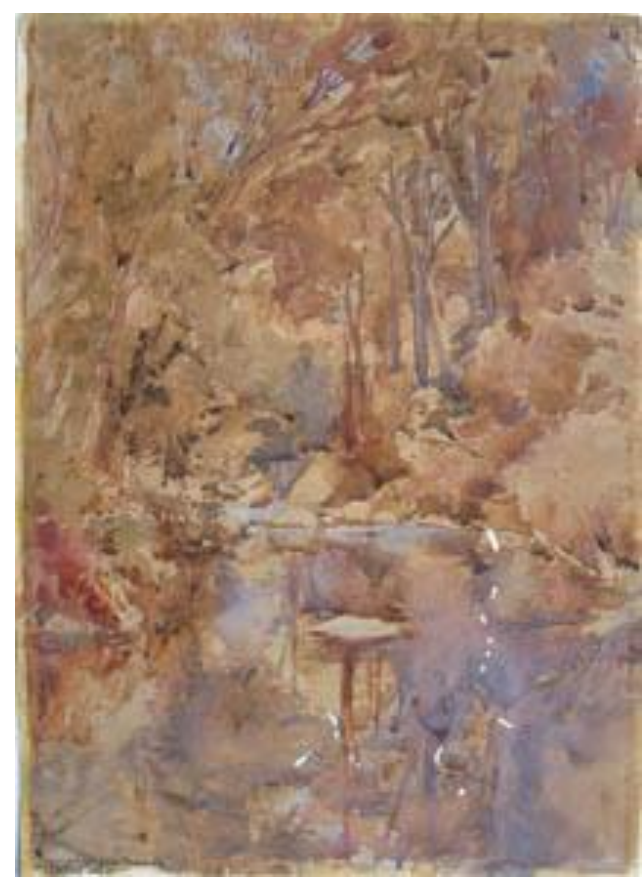

Fig. 32. Aquarela com inscrição "Corrigido por Benno Treidler", e assinatura de Alberto de Sampaio, s.d. 


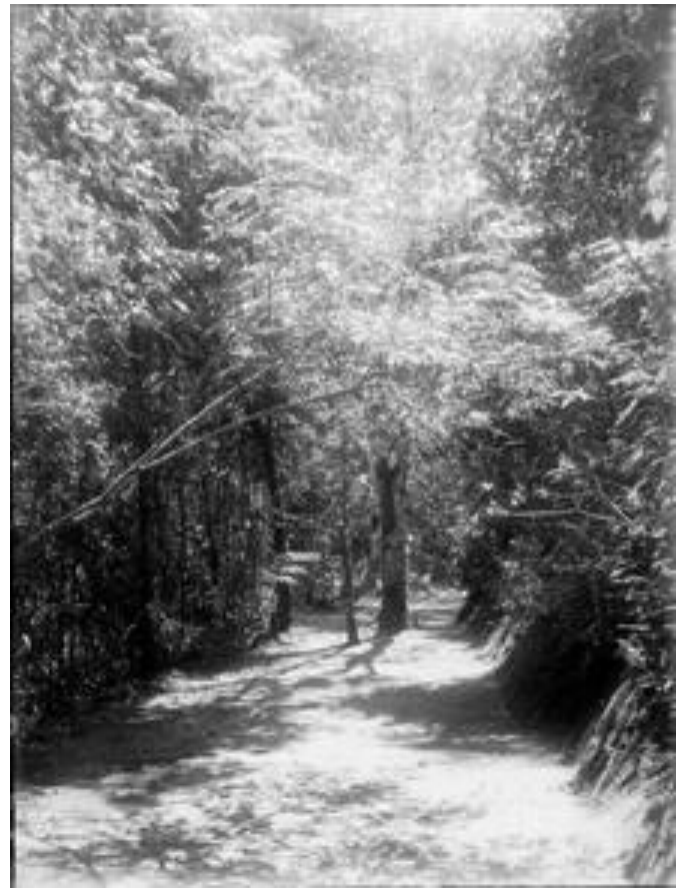

Fig. 33. Interior da matta, 1905. Negativo em vidro. Gelatina/prata, 10 x $8,5 \mathrm{~cm}$. Legenda original.

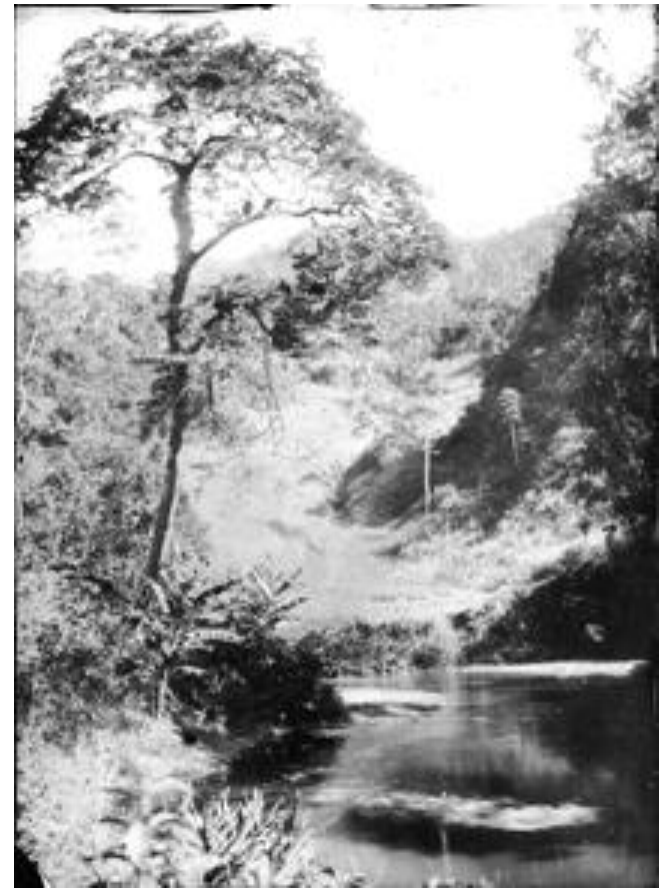

Fig. 34. Árvore no rio. Negativo em vidro. Gelatina/prata, 10 x $8,5 \mathrm{~cm}$. Legenda atribuída.

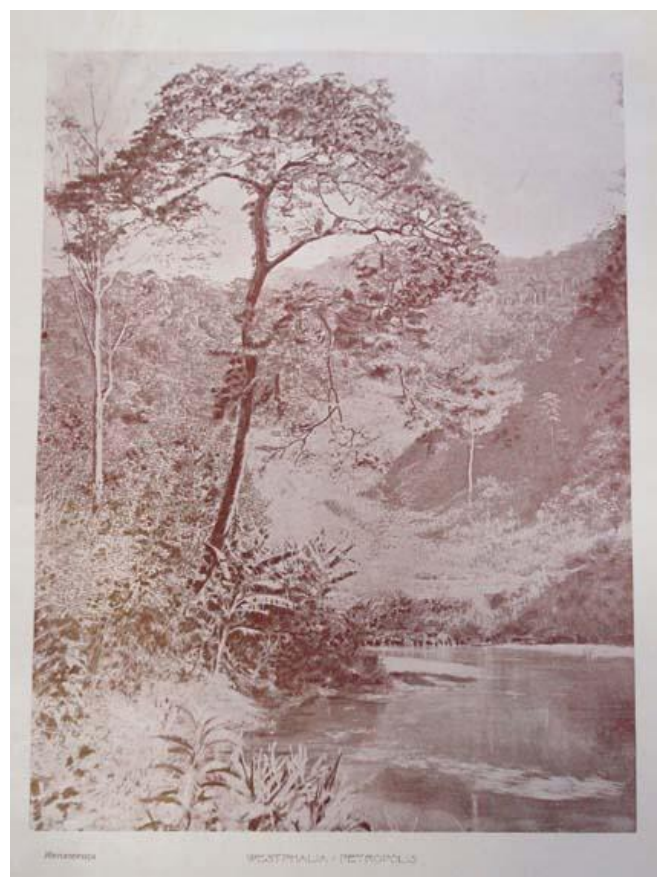

Fig. 34. 1. Westphalia-Petrópolis. Revista Renascença, maio de 1907. Legenda original.

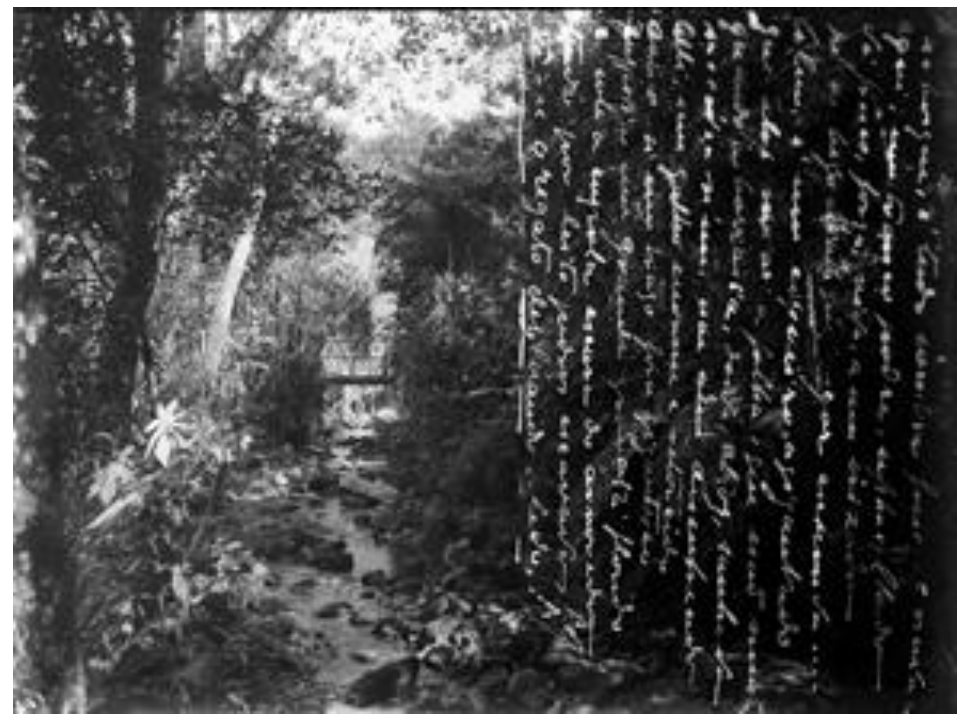

Fig. 35. Bosque com poema "Paysagem" [1905-10]. Negativo em vidro. Gelatina/prata, 12 x $16 \mathrm{~cm}$. Legenda atribuída. 


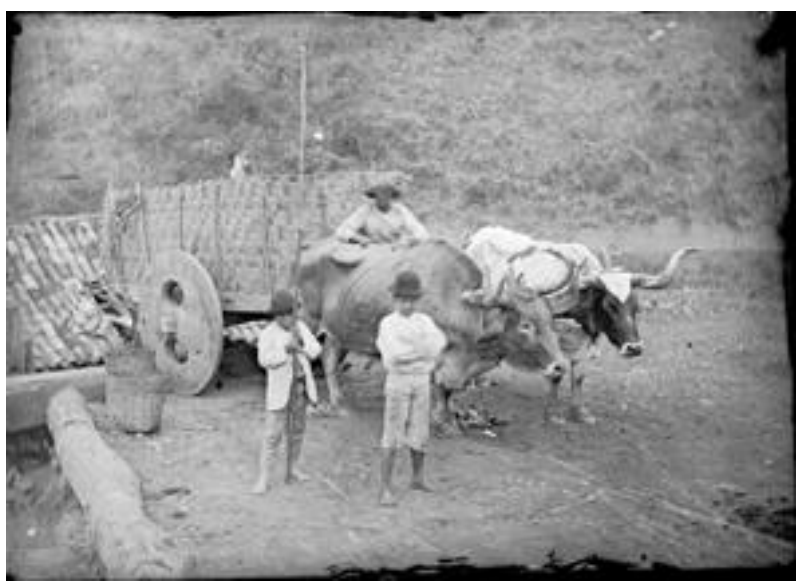

Fig. 36. Despolpador em Santa Alda, 1895. Negativo em vidro. Gelatina/prata, 10 x $8,5 \mathrm{~cm}$. Legenda original.

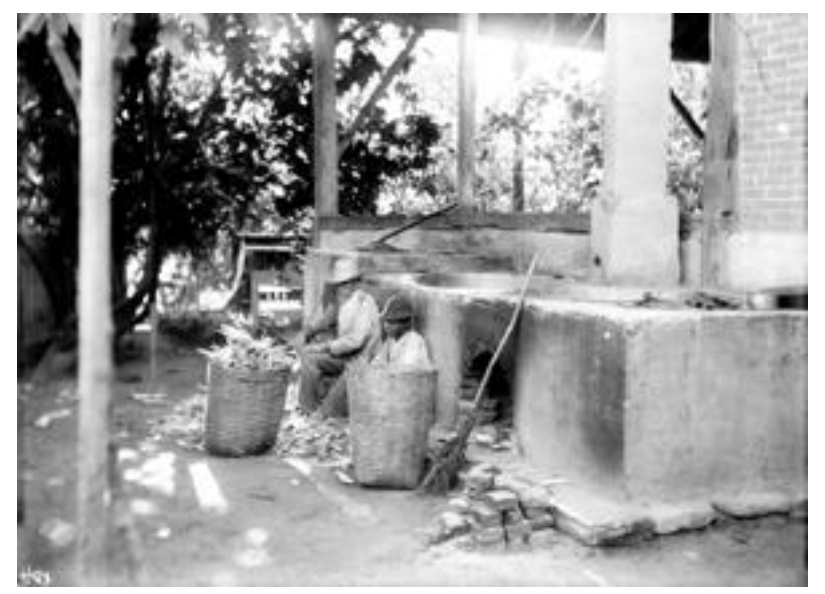

Fig.38. Homens descascando milho [1905-10]. Negativo em vidro. Gelatina/prata, 12 x $16 \mathrm{~cm}$. Legenda atribuída.

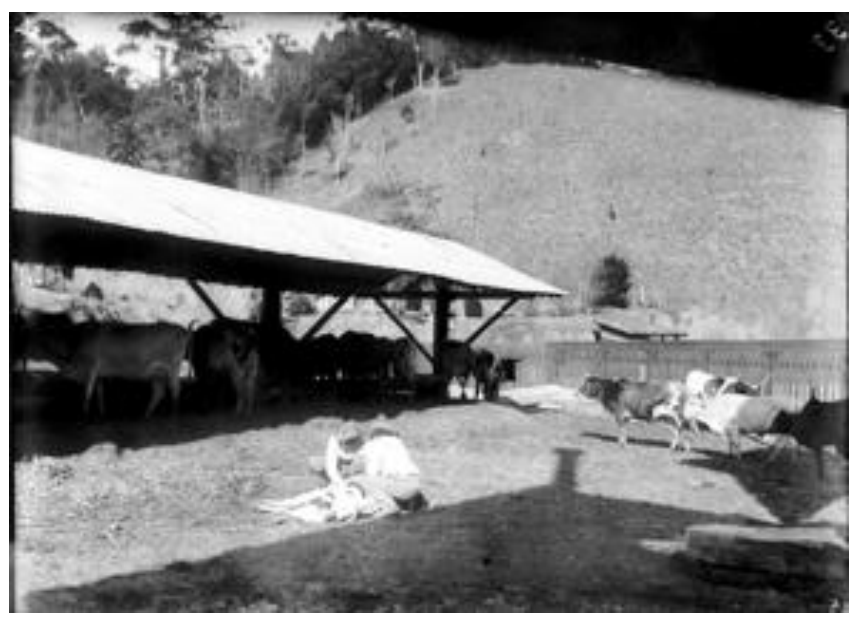

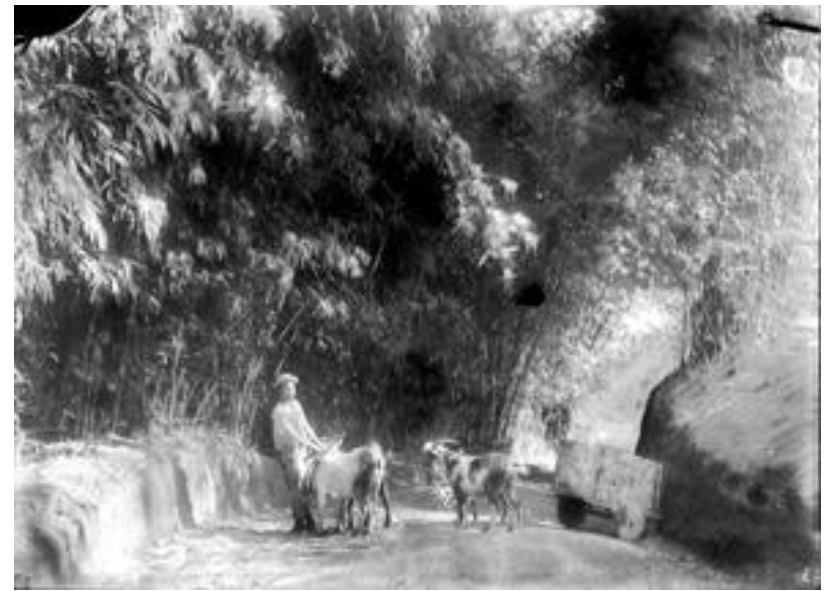

Fig. 37. Carro de cabritos em Santa Alta, 1905.

Negativo em vidro. Gelatina/prata, 12 x $16 \mathrm{~cm}$. Legenda original.

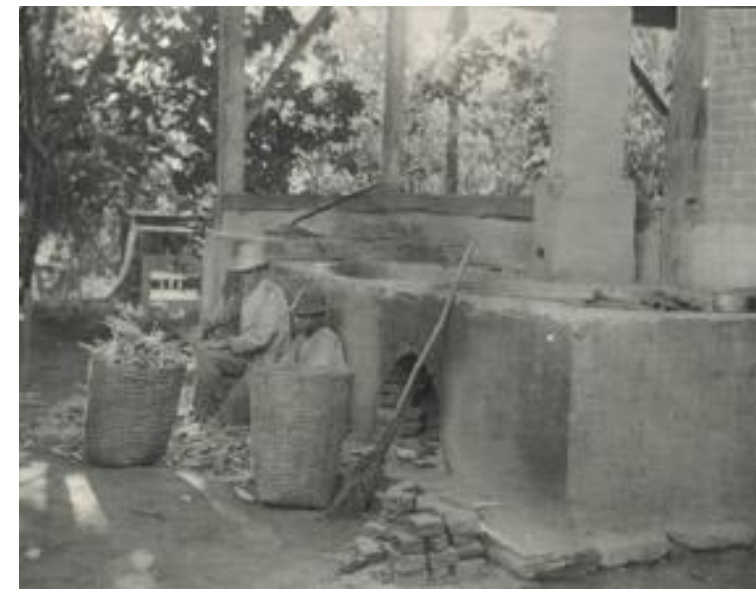

Fig. 38.1. Cópia em papel, platinotipia.

Fig. 39. Curando bezerros em Sta. Alda, 1905. Negativo em vidro. Gelatina/prata, 12 x $16 \mathrm{~cm}$. Legenda original. 


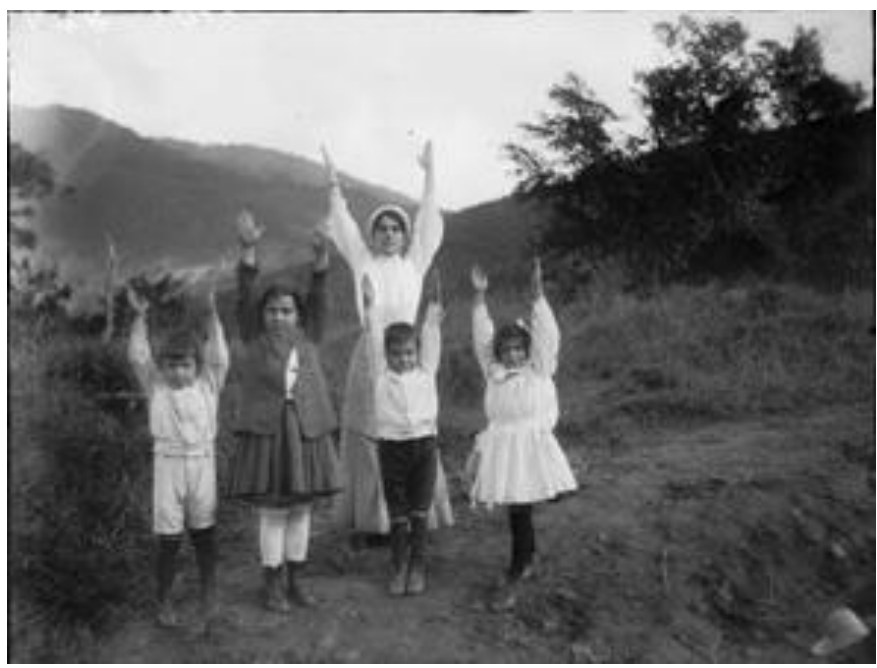

Fig. 40. Gymastica no pic-nic, 1905. Negativo em vidro. Gelatina/prata, 10 x $8,5 \mathrm{~cm}$. Legenda original.
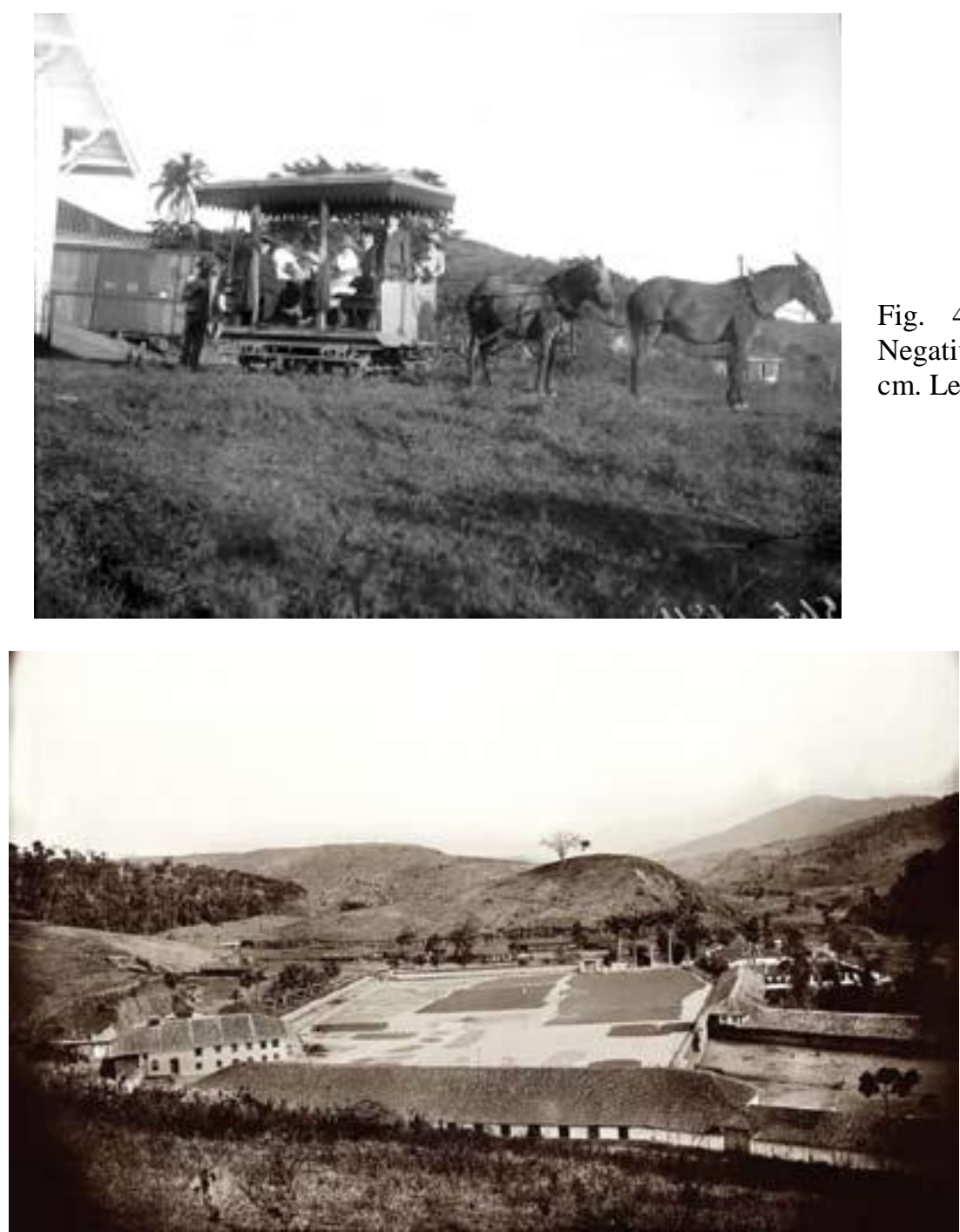

Fig. 41. Bonde em Chacrinha, 1905 Negativo em vidro. Gelatina/prata, 10 x 8,5 $\mathrm{cm}$. Legenda original.
Fig 42. Fazenda Campo Alegre, século XIX. Marc Ferrez, Coleção Gilberto Ferrez do Instituto Moreira Salles (Novaes, s/d: 411). 


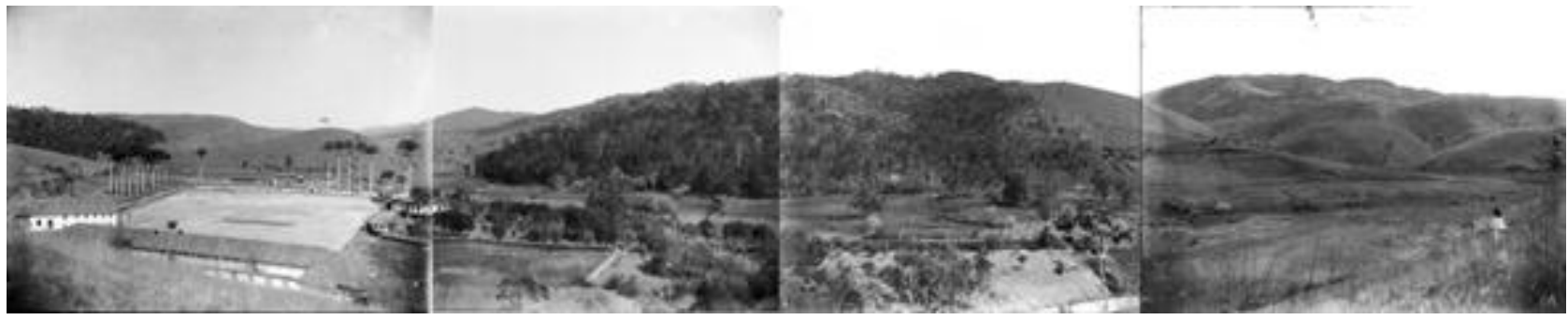

Fig. 43. Fazenda Campo Alegre [1900-10]. Negativo em vidro (quatro chapas). Gelatina/prata, 12 x $16 \mathrm{~cm}$. Legenda atribuída.

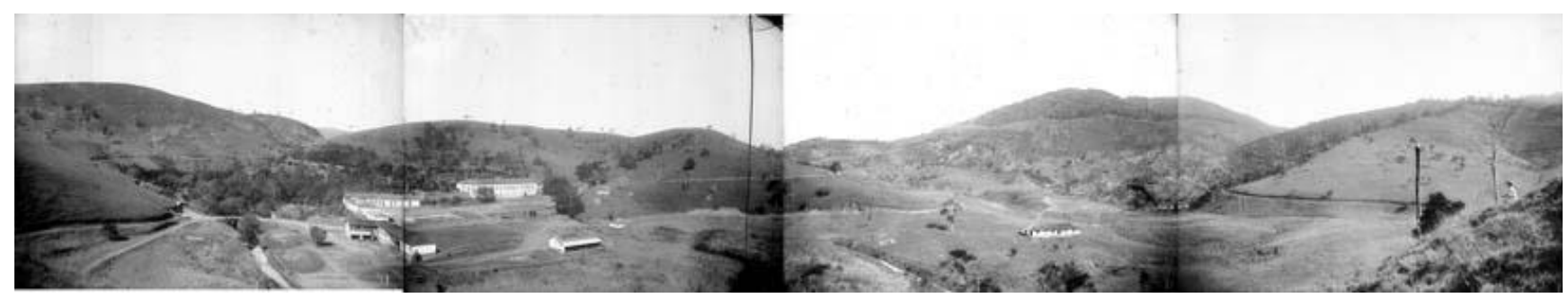

Fig. 44. Fazenda Chacrinha [1900-10]. Negativo em vidro (quatro chapas). Gelatina/prata, 12 x $16 \mathrm{~cm}$. Legenda atribuída.

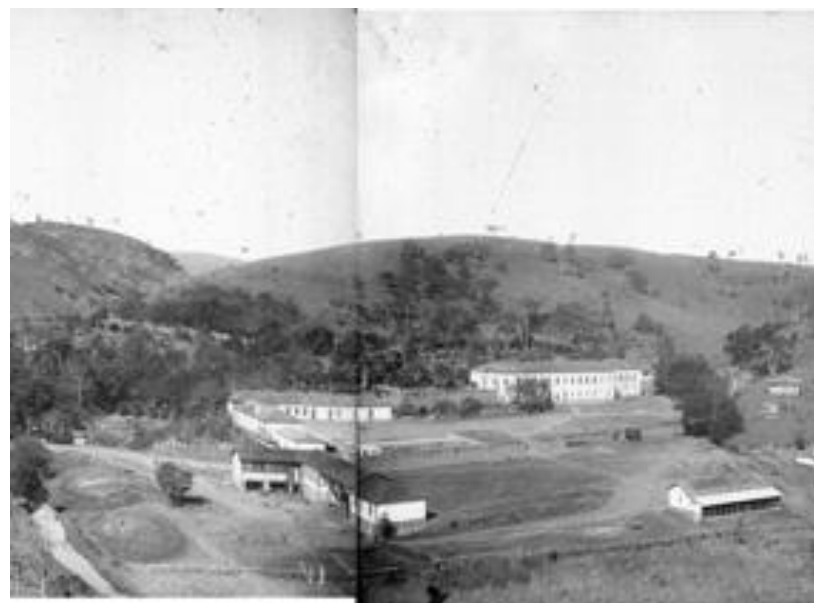

Fig. 44.1. Detalhe, Fazenda Chacrinha.

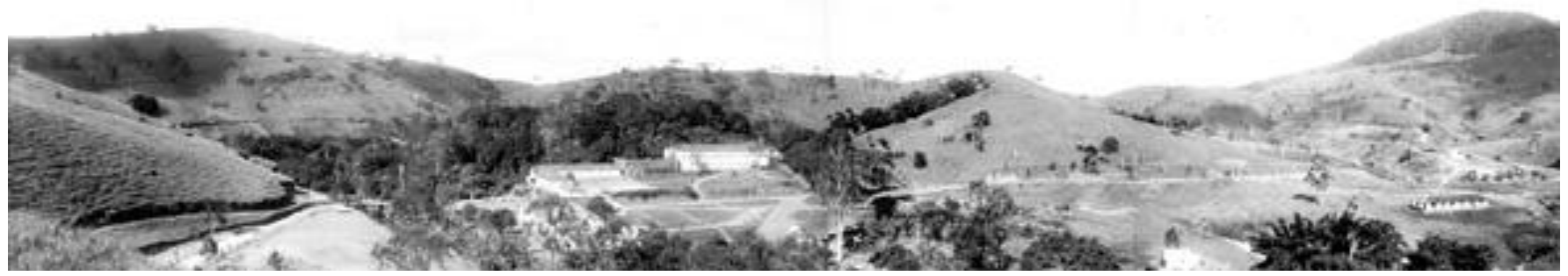

Fig. 45. Fazenda Chacrinha, s/d. Negativo em vidro (quatro chapas). Gelatina/prata, 12 x $16 \mathrm{~cm}$. Legenda atribuída. 

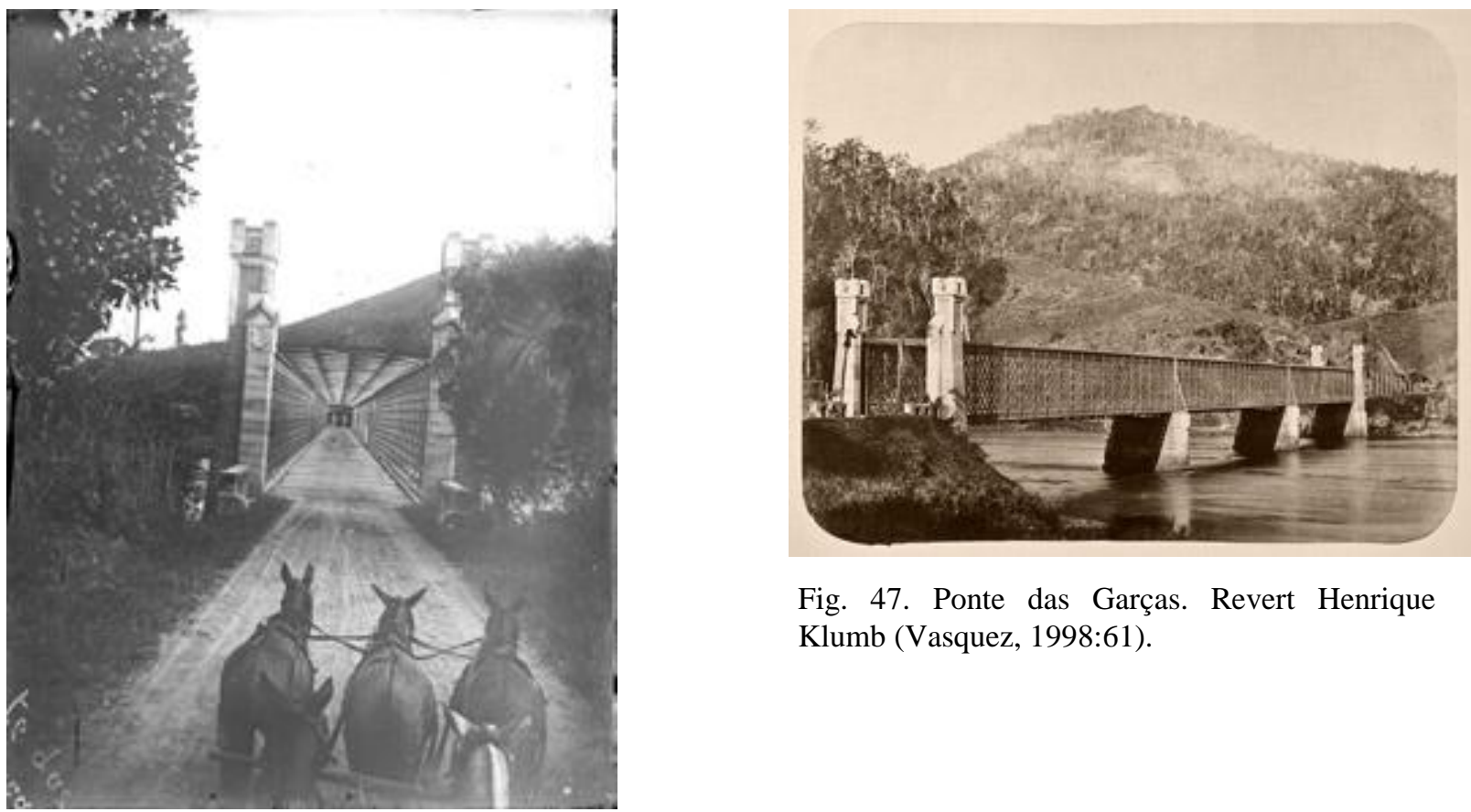

Fig. 47. Ponte das Garças. Revert Henrique Klumb (Vasquez, 1998:61).

Fig. 46. Ponte das Garças, 1895. Negativo em vidro. Gelatina/prata, 10 x 8,5 cm. Legenda original.
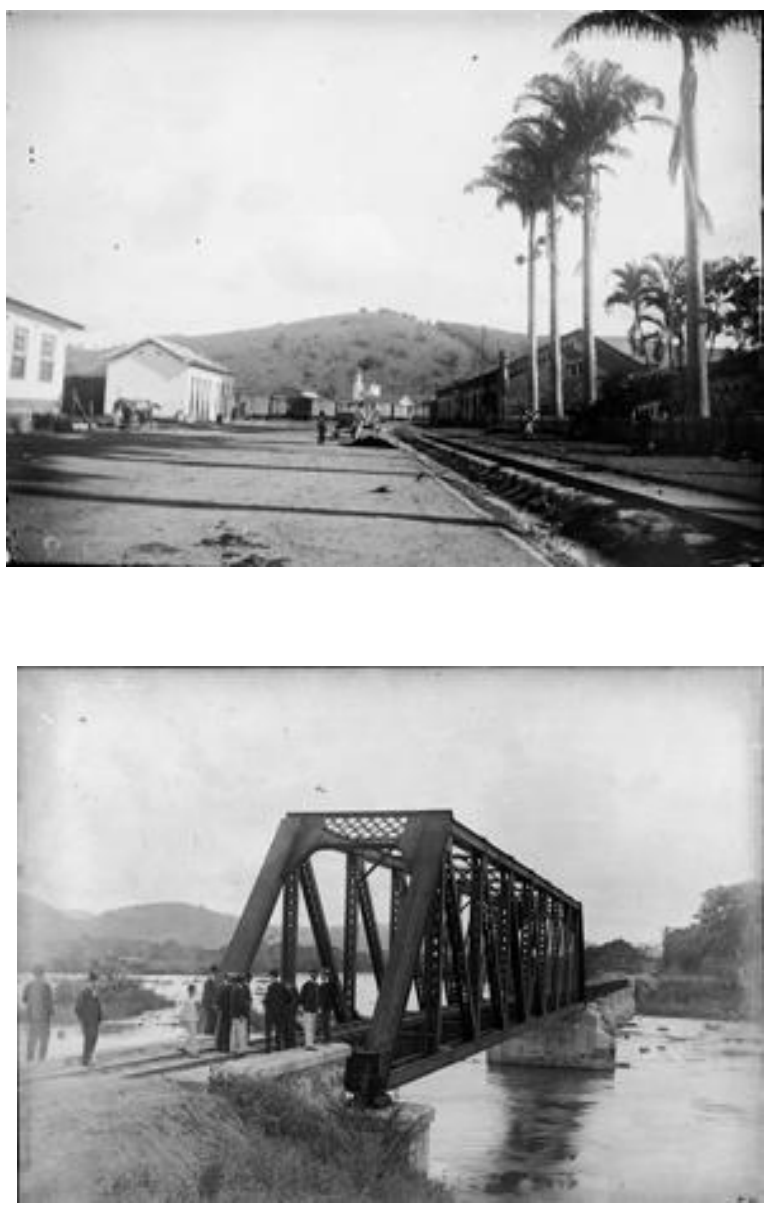

Fig. 48. Entre Rios, 1895. Negativo em vidro. Gelatina/prata, 10 x $8,5 \mathrm{~cm}$. Legenda original.
Fig. 49. Ponte do Travessão, 1905. Negativo em vidro. Gelatina/prata, 10 $\mathrm{x} 8,5 \mathrm{~cm}$. Legenda original. 


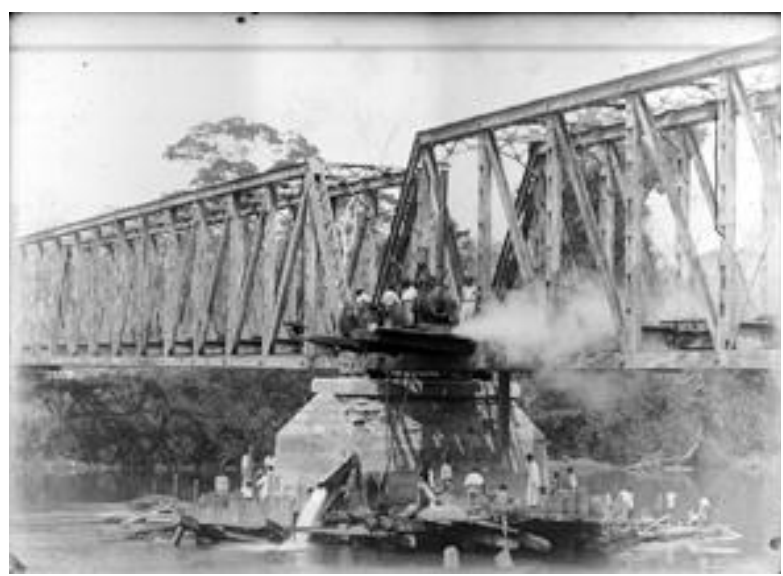

Fig. 50. Obras em ponte não identificada, s/d. Negativo em vidro. Gelatina/prata, 10 x $8,5 \mathrm{~cm}$. Legenda atribuída.

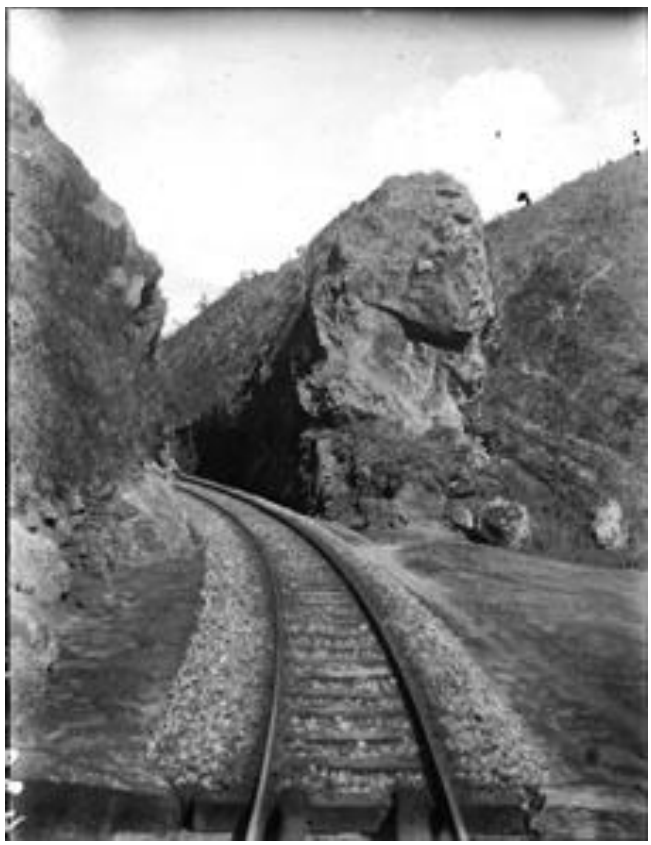

Fig. 51. Corte na linha Estrada de Ouro Ouro Preto. Negativo em vidro. Gelatina/prata, 10 x $8,5 \mathrm{~cm}$. Legenda original.

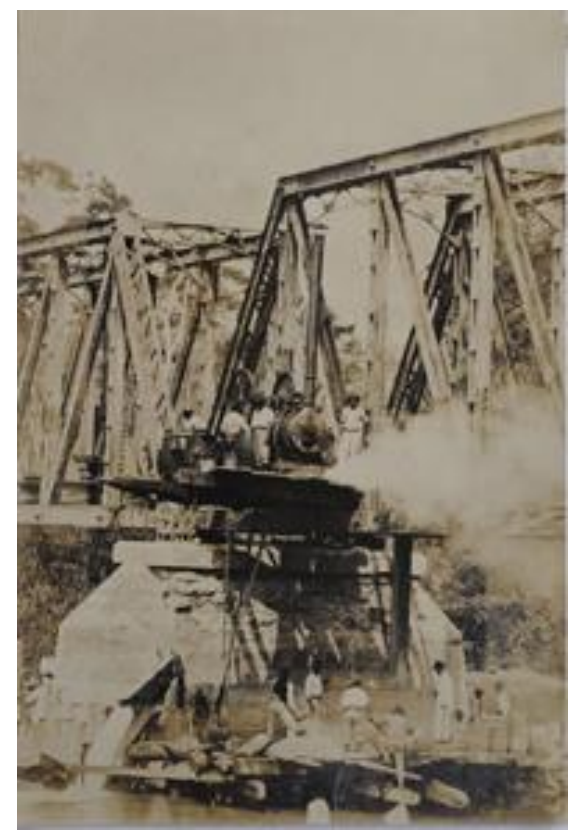

Fig. 50.1. Cópia em papel, editada por Alberto de Sampaio.

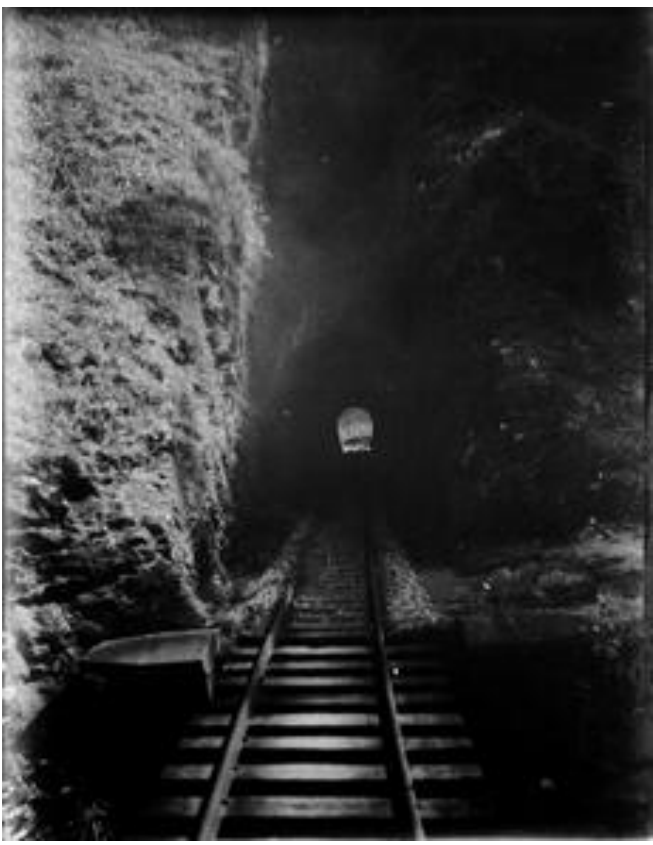

Fig. 52. Túnel na linha Ouro Preto. Negativo em vidro. Gelatina/prata, 10 x 8,5 $\mathrm{cm}$. Legenda original. 


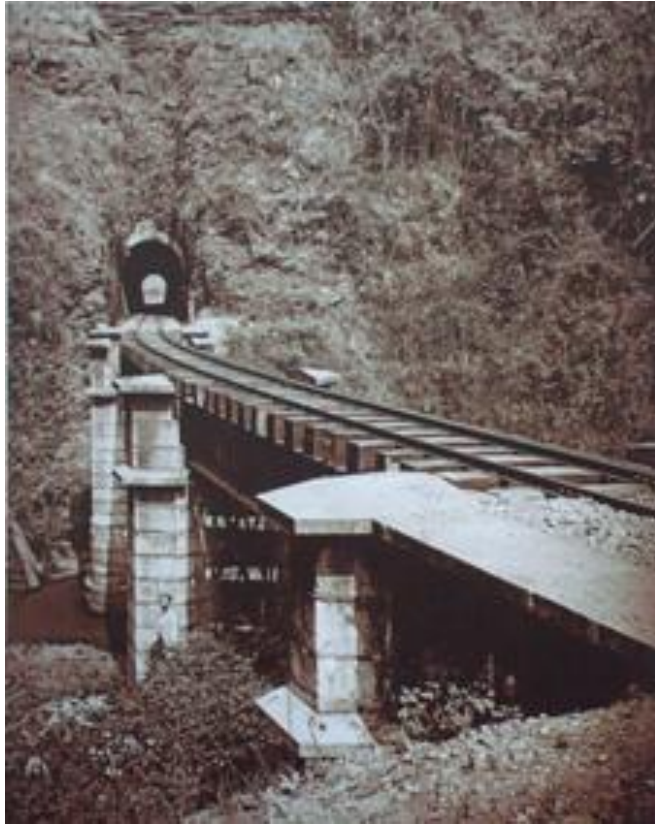

Fig. 53. Ponte e túnel, c. 1880. Coleção Gilberto Ferrez do Instituto Moreira Salles (Vasquez, 2007: 194)

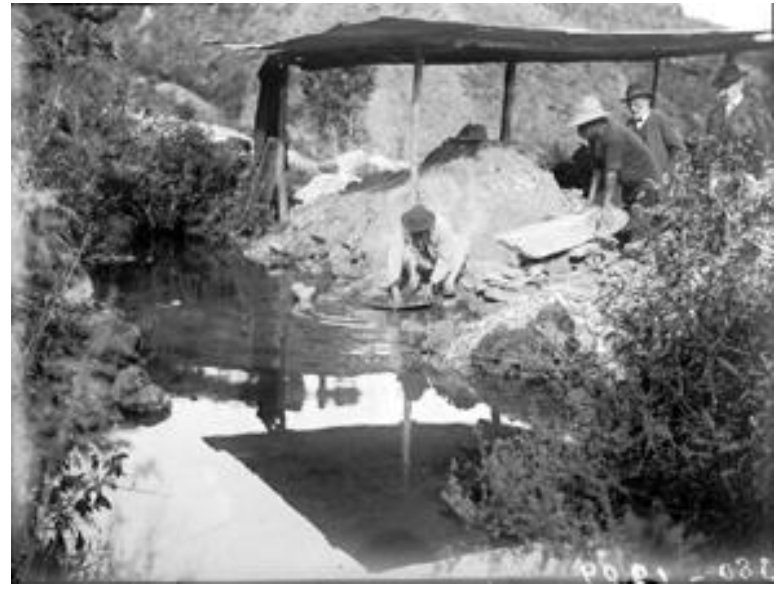

Fig. 54. Bateada em Tássaras, 1909. Negativo em vidro. Gelatina/prata, 10 x $8,5 \mathrm{~cm}$. Legenda original.

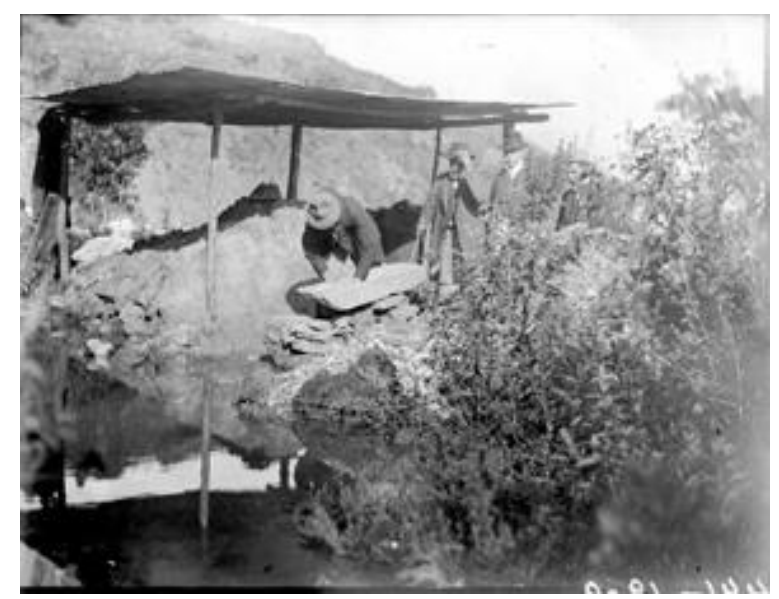

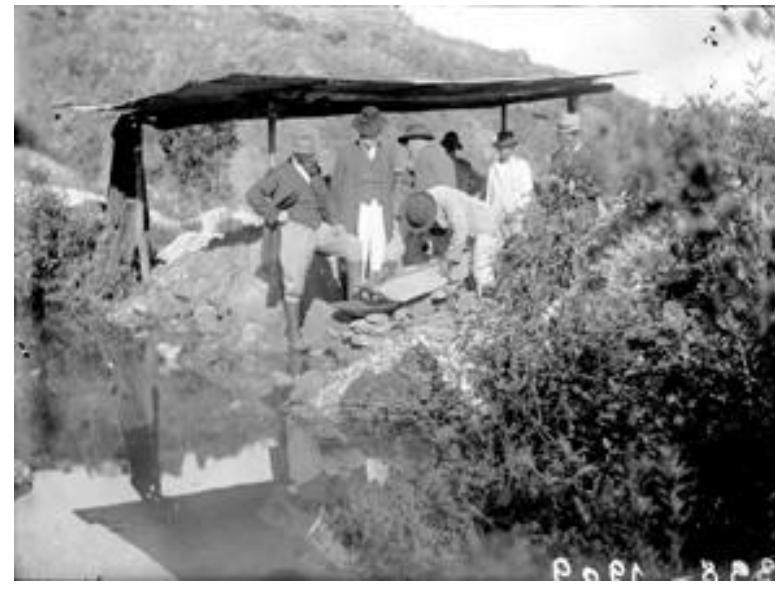

Fig. 55. Moendo cascalhos em Tássaras, 1909. Negativo em vidro. Gelatina/prata, 10 x $8,5 \mathrm{~cm}$. Legenda original.

Fig. 56. Moendo cascalhos em Tássaras, 1909. Negativo em vidro. Gelatina/prata, 10 x 8,5 cm. Legenda original. 


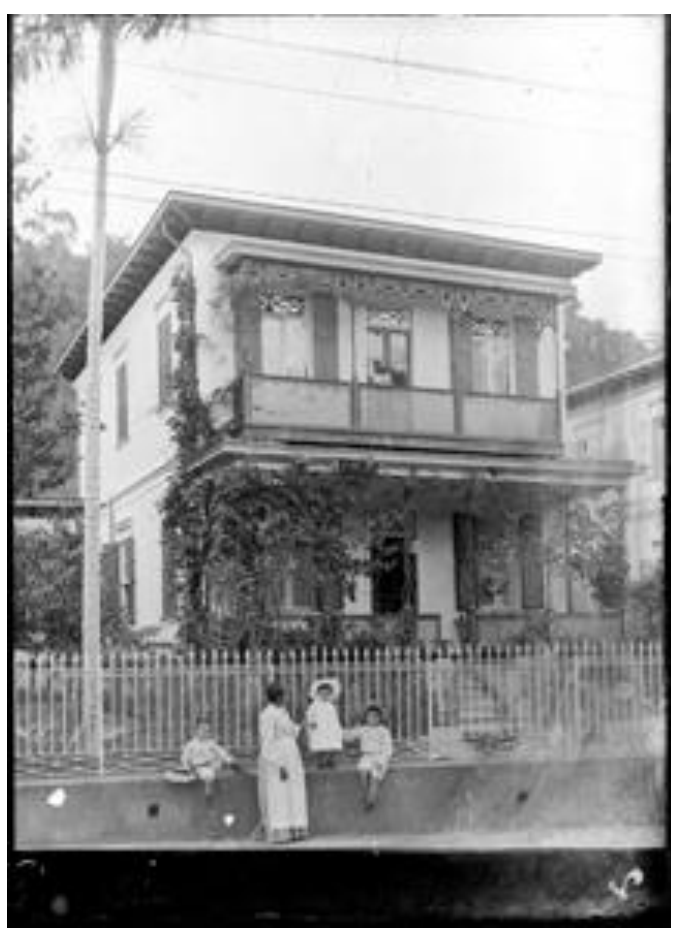

Fig. 57. Casa rua Souza Franco com as crianças, 1903. Negativo em vidro. Gelatina/prata, 12 x 16 $\mathrm{cm}$. Legenda original.

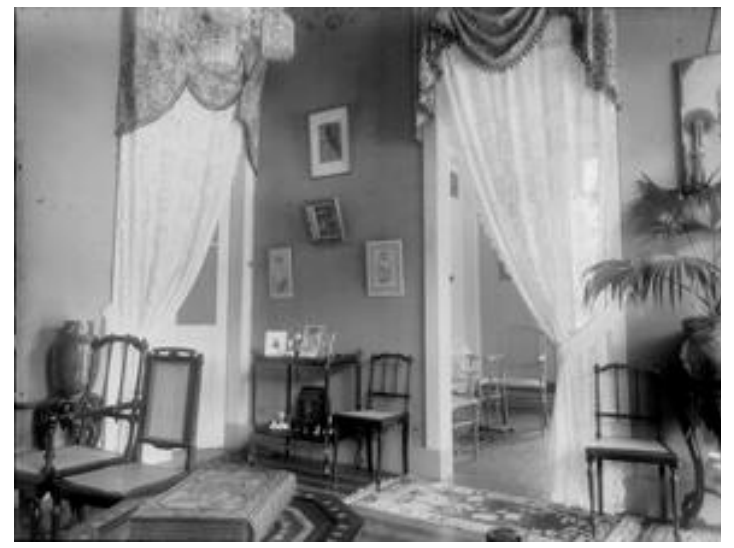

Fig. 59. Sala de estar da casa na rua Souza Franco [1903-10]. Negativo em vidro. Gelatina/prata, 10 x 8,5 cm. Legenda atribuída.

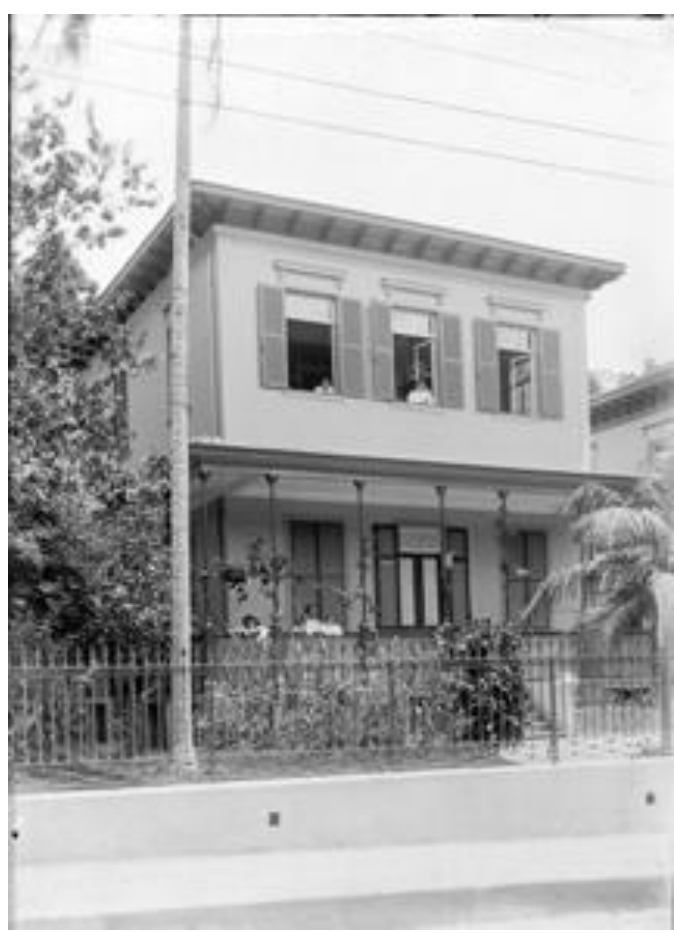

Fig. 58. Casa na rua Souza Franco, 1906. Negativo em vidro. Gelatina/prata, 12 x $16 \mathrm{~cm}$. Legenda atribuída.

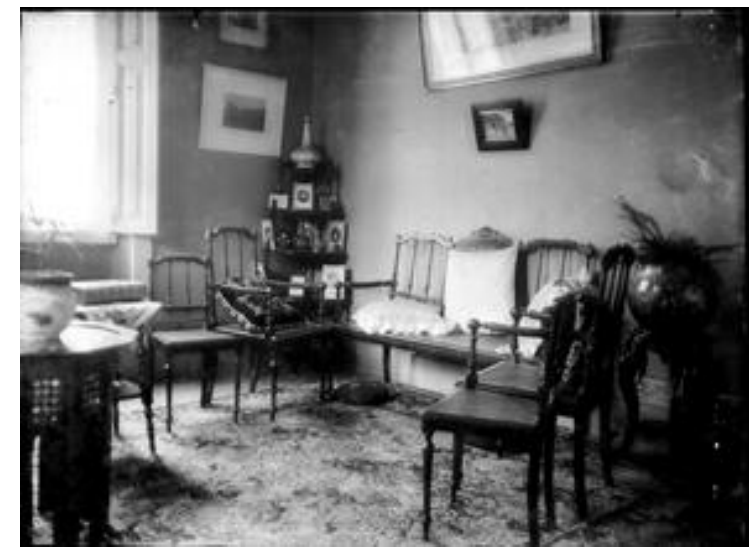

Fig. 60. Sala de visitas em minha casa S. Franco, 1905. Negativo em vidro. Gelatina/prata, 12 x 16 $\mathrm{cm}$. Legenda original. 


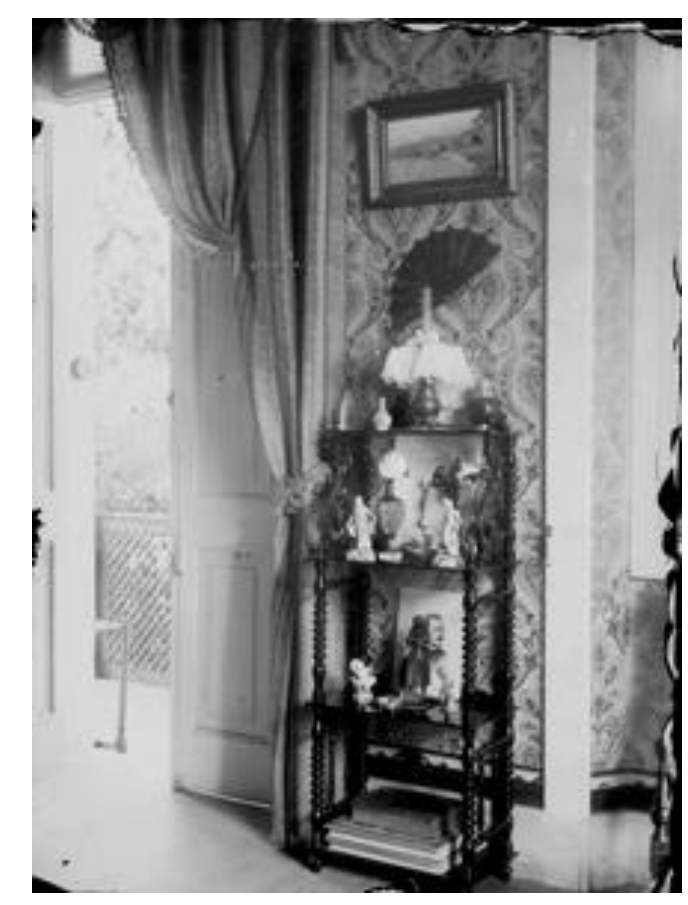

Fig. 61. Sala de estar da casa na Rua Souza Franco [1903-05]. Negativo em vidro. Gelatina/prata, 10 x $8,5 \mathrm{~cm}$. Legenda atribuída.

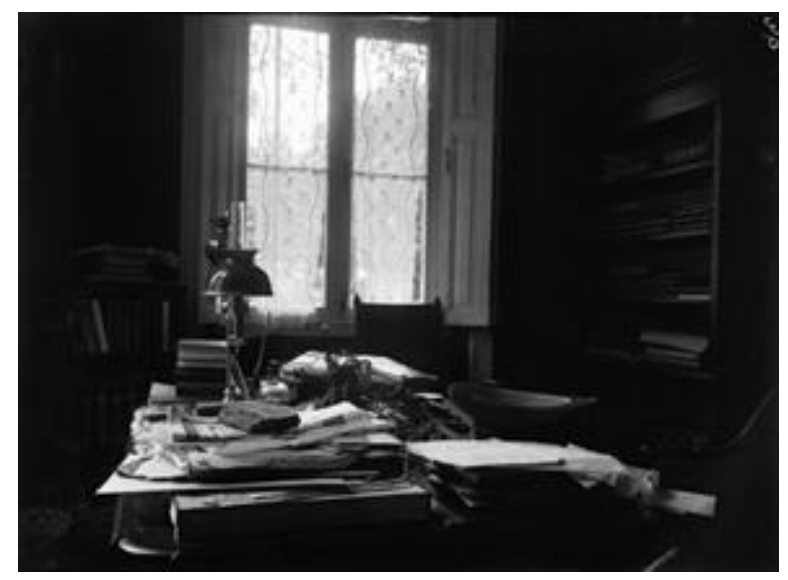

Fig. 63. Minha mesa no gabinete, 1905. Negativo em vidro. Gelatina/prata, 12 x $16 \mathrm{~cm}$. Legenda original.

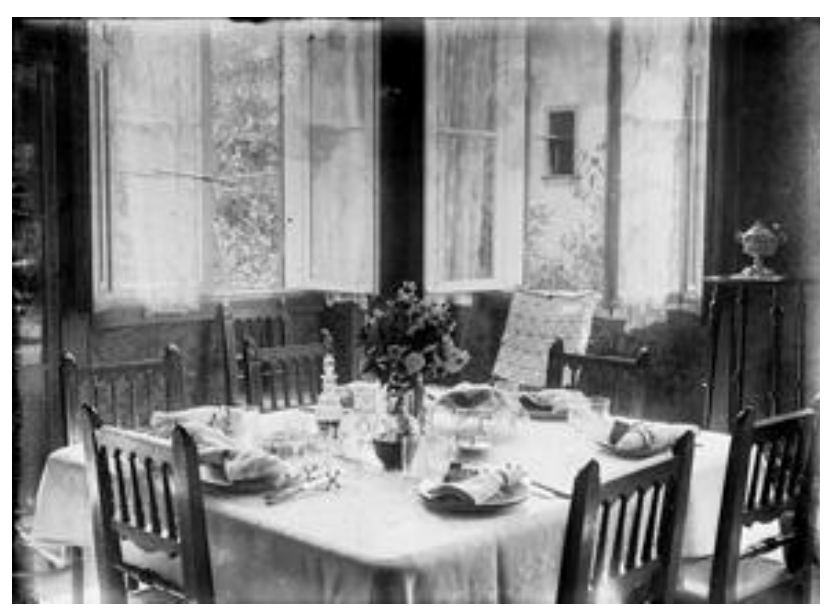

Fig. 62. Mesa de jantar em minha casa, 1905. Negativo em vidro. Gelatina/prata, 12 x $16 \mathrm{~cm}$. Legenda original.

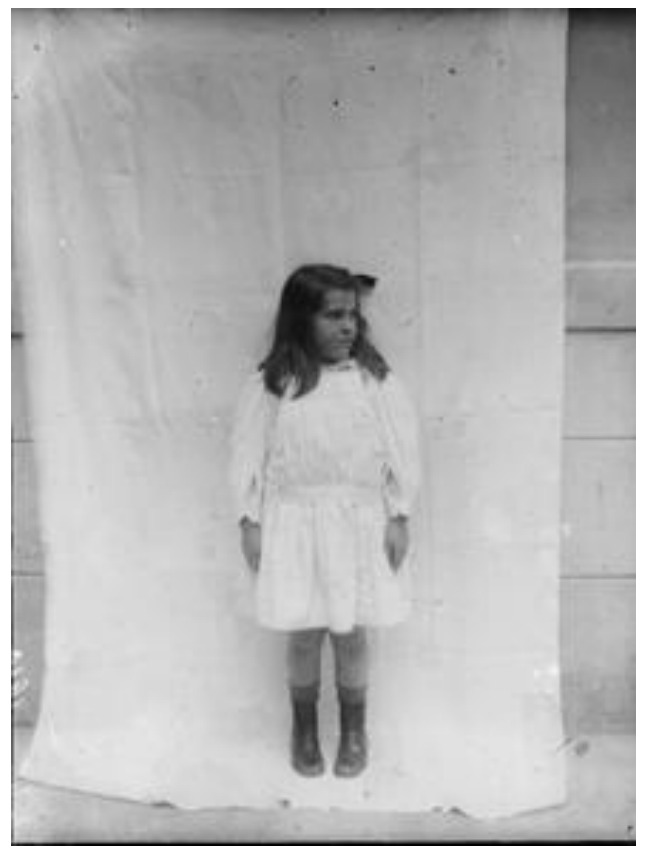

Fig. 64. Luluta, 1910. Negativo em vidro. Gelatina/prata, 10 x $8,5 \mathrm{~cm}$. Legenda original. 


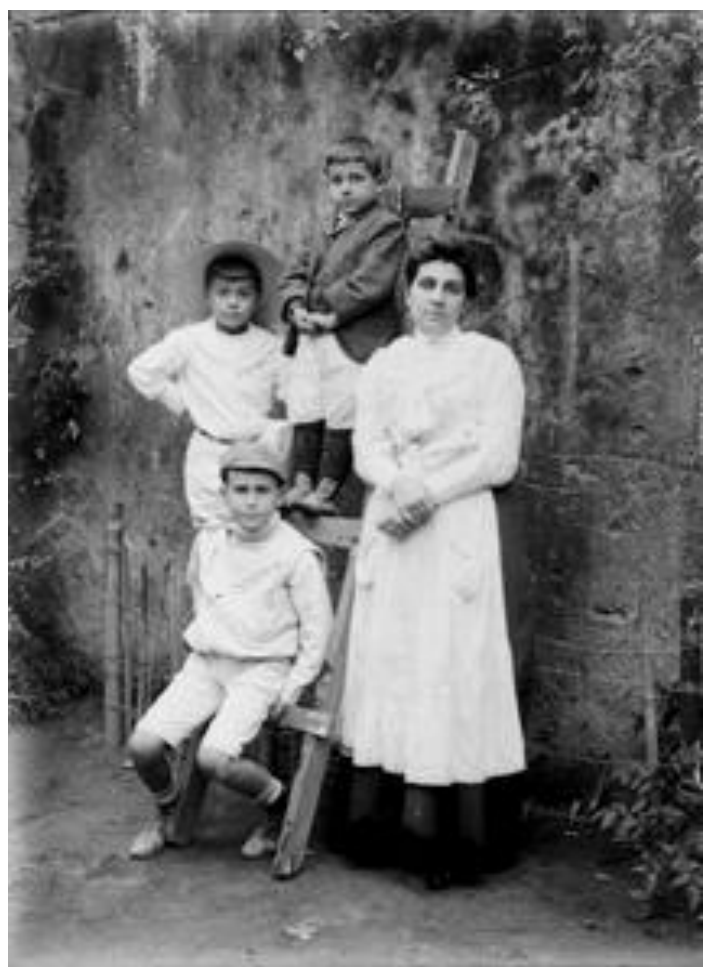

Fig. 65. Cecília com filhos. Negativo em vidro. Gelatina/prata, 12 x $16 \mathrm{~cm}$. Legenda atribuída.

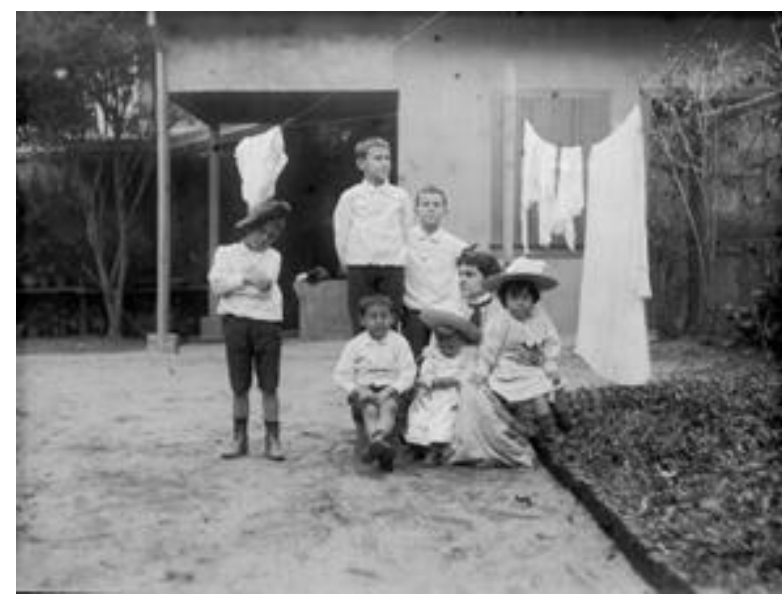

Fig. 66. Cecília e creanças no páteo de casa, 1907. Negativo em vidro. Gelatina/prata, 12 x $16 \mathrm{~cm}$. Legenda original.

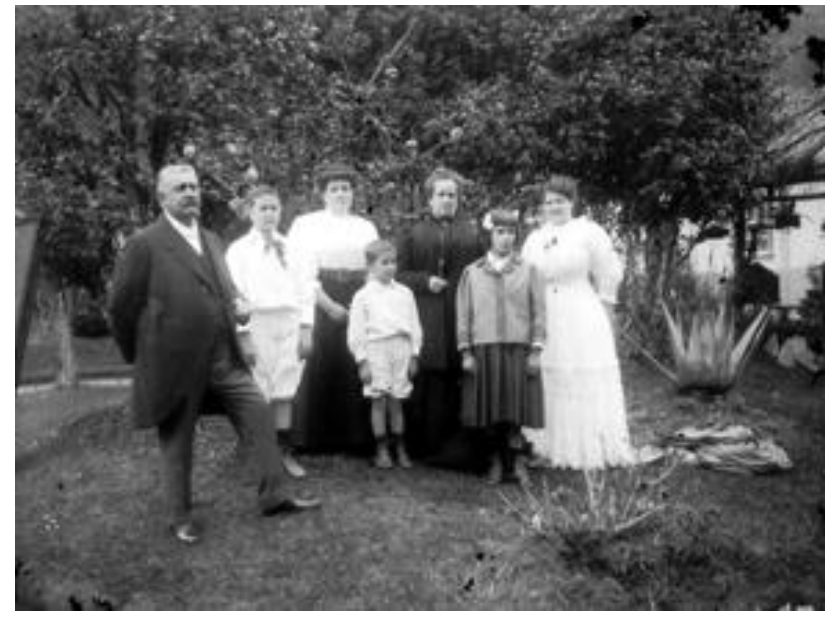

Fig. 67. Família Ed. Rudge, 1910. Negativo em vidro. Gelatina/prata, 10 x 8,5 cm. Legenda original.

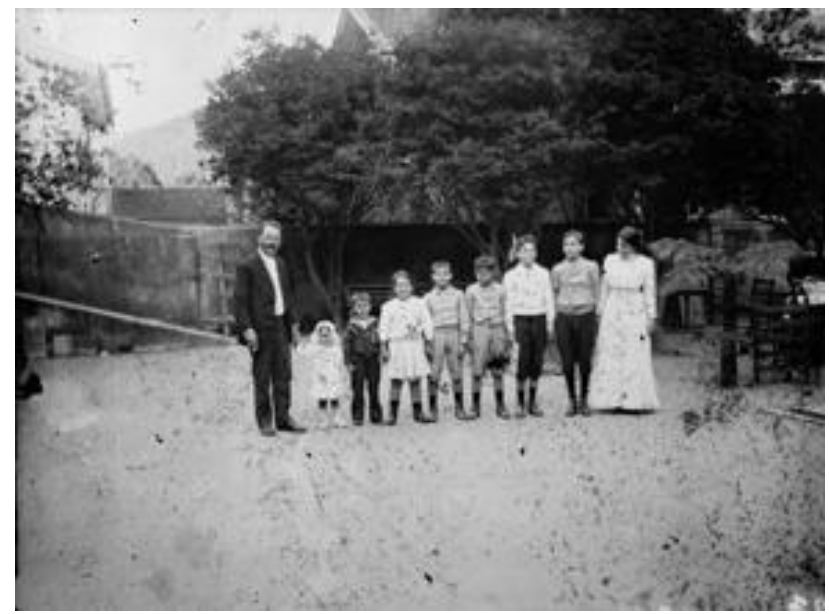

Fig. 68. Minha família, 1911. Negativo em vidro. Gelatina/prata, 10 x 8,5 cm. Legenda original. 

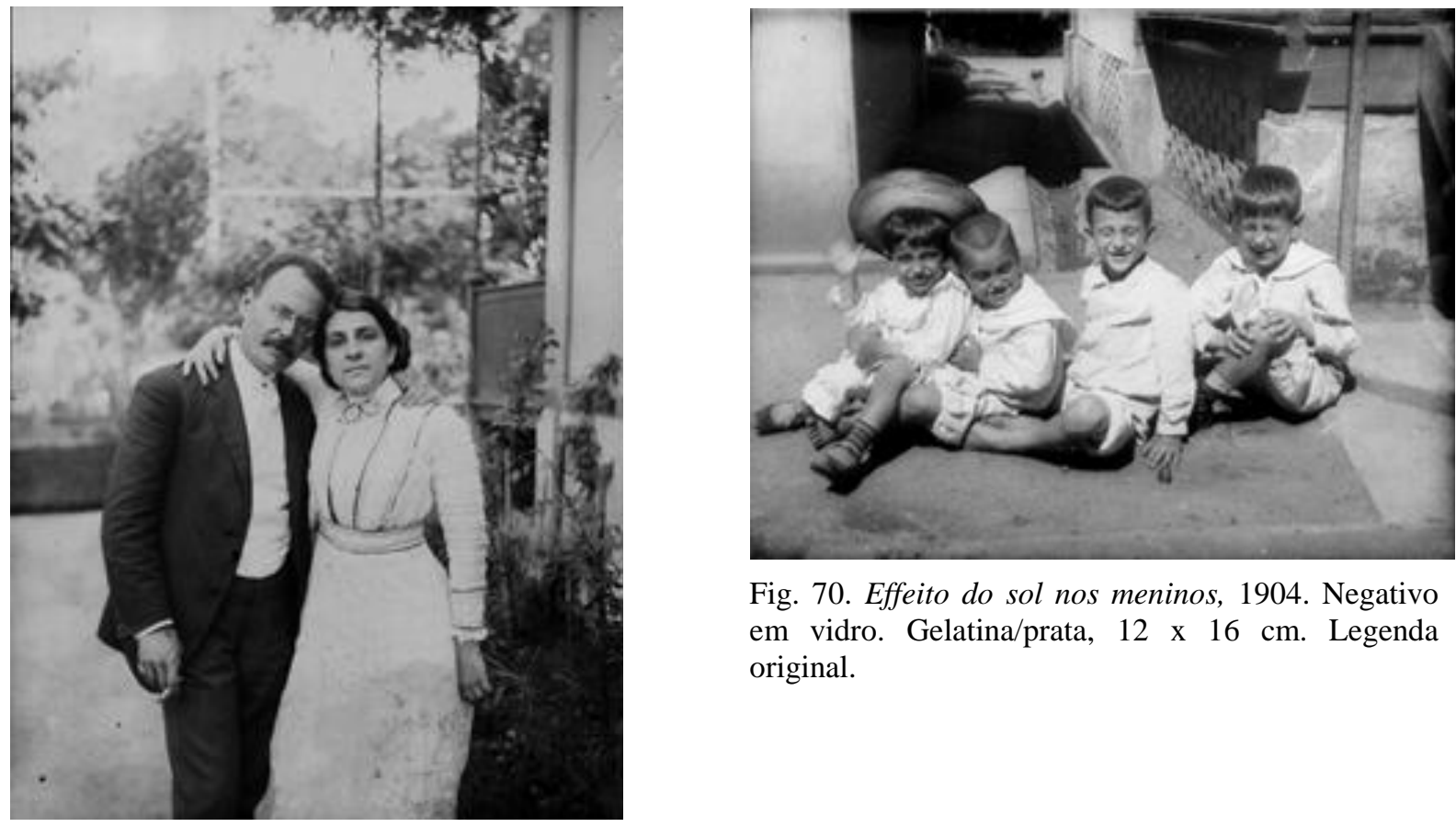

Fig. 70. Effeito do sol nos meninos, 1904. Negativo em vidro. Gelatina/prata, 12 x $16 \mathrm{~cm}$. Legenda original.

Fig. 69. Eu e Cecília, 1910. Negativo em vidro. Gelatina/prata, 10 x $8,5 \mathrm{~cm}$. Legenda original.

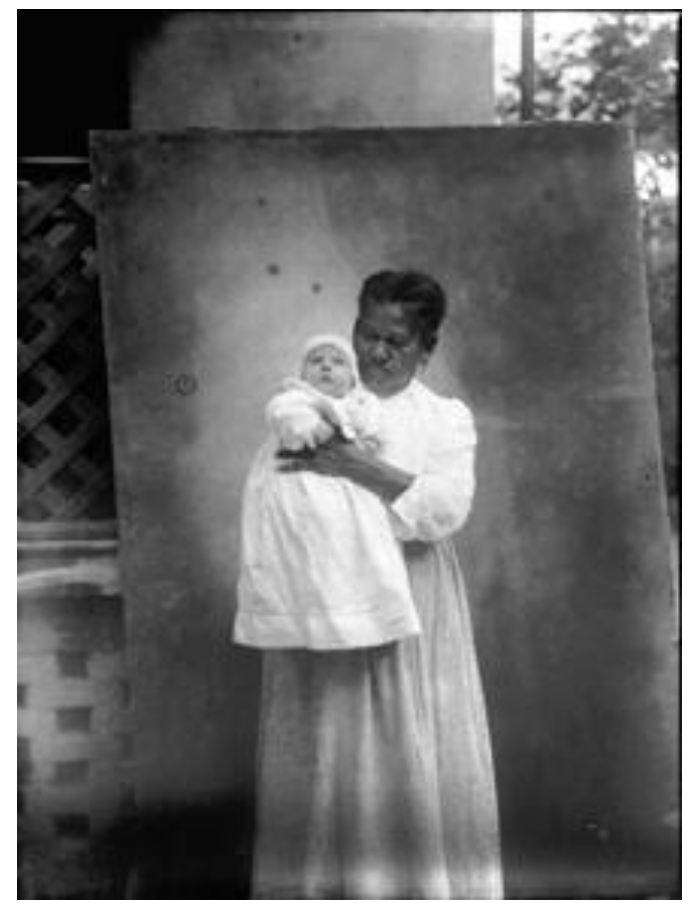

Fig. 71. Criança com babá no quintal [190310]. Negativo em vidro. Gelatina/prata, $10 \mathrm{x}$ $8,5 \mathrm{~cm}$. Legenda atribuída. 


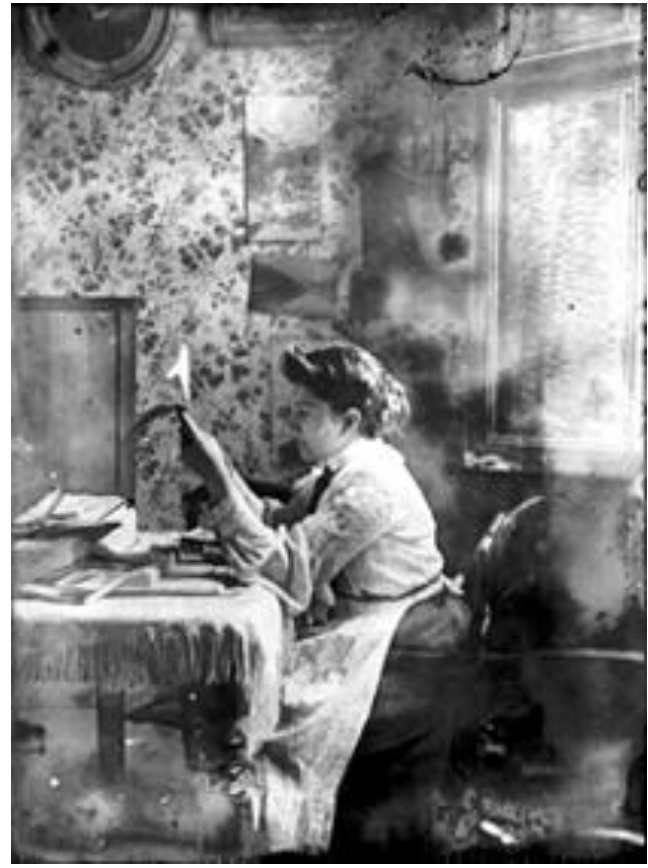

Fig. 72. Cecília lendo no gabinete, 1905. Negativo em vidro. Gelatina/prata, 10 x 8,5 $\mathrm{cm}$. Legenda original.

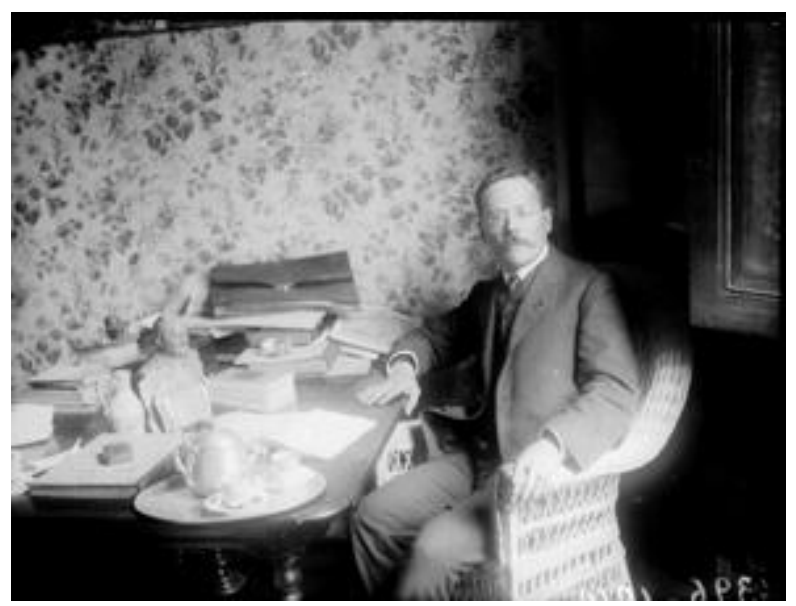

Fig. 74. Meu retrato no gabinete, 1910. Negativo em vidro. Gelatina/prata, 10 x $8,5 \mathrm{~cm}$. Legenda original.

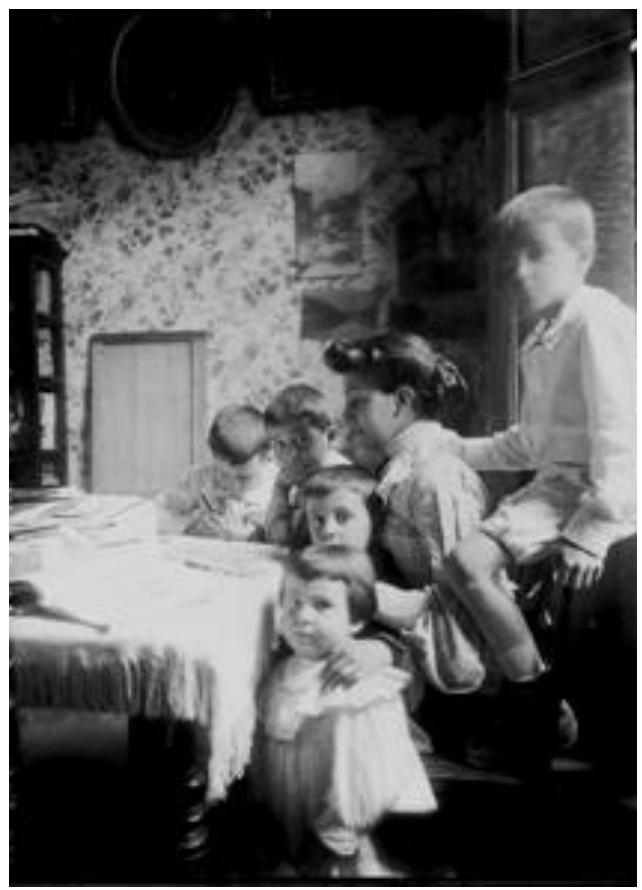

Fig. 73. Cecília com crianças, 1905. Negativo em vidro. Gelatina/prata, 12 x $16 \mathrm{~cm}$. Legenda atribuída.

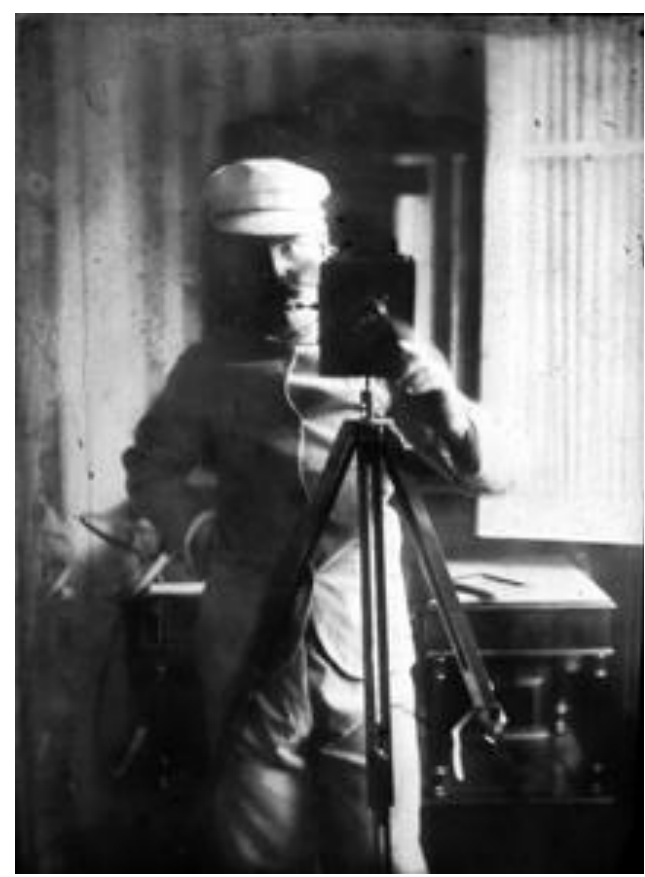

Fig. 75. Auto-retrato de Alberto de Sampaio [1900-10]. Negativo em vidro. Gelatina/prata, $10 \times 8,5 \mathrm{~cm}$. Legenda atribuída. 


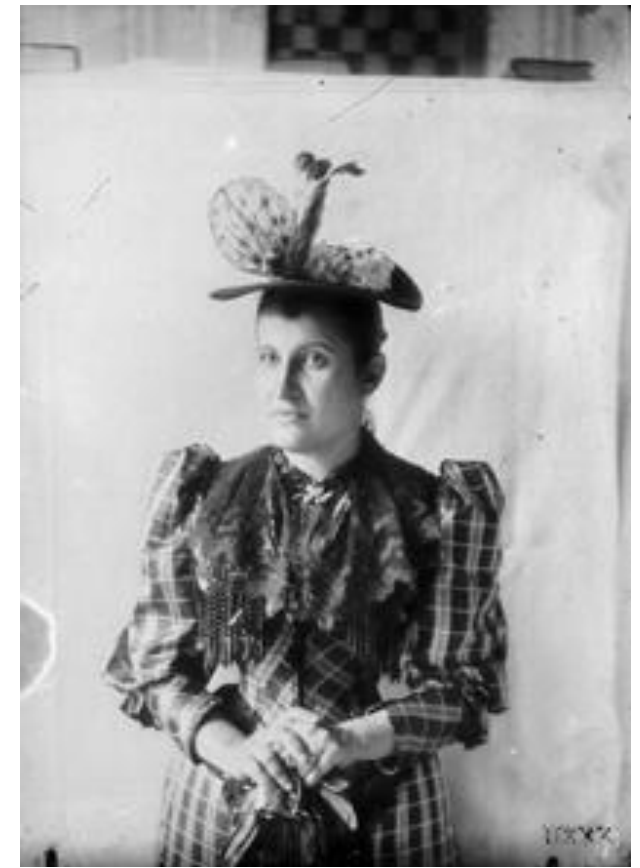

Fig. 76. Retrato de Nanhã, 1890. Negativo em vidro. Gelatina/prata, $12 \mathrm{x}$ $16 \mathrm{~cm}$. Legenda original.

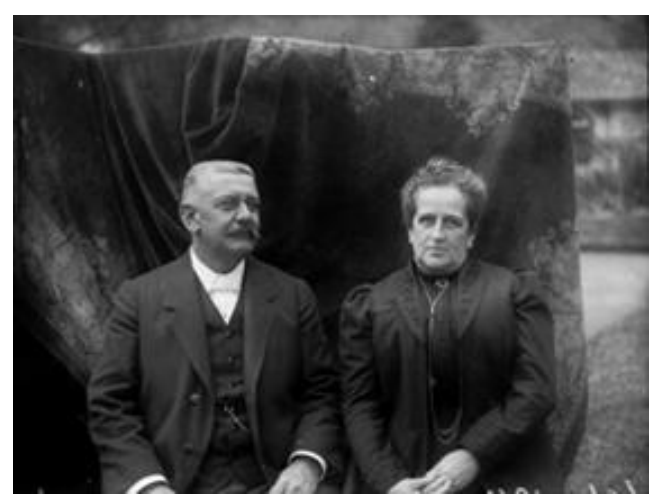

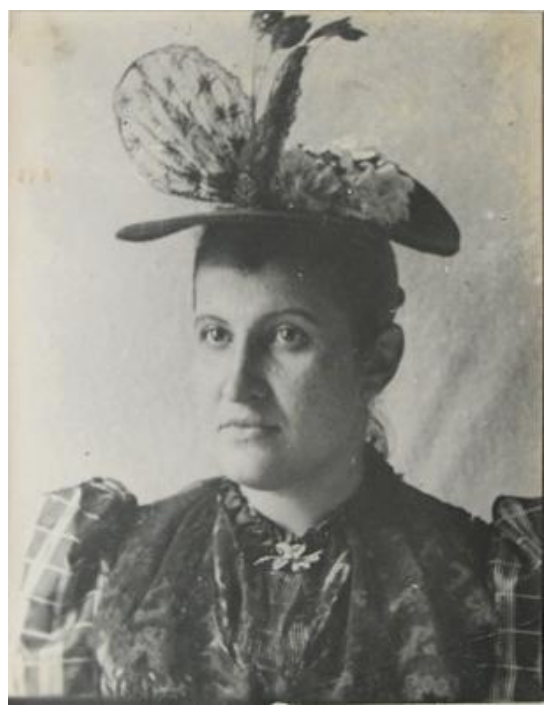

Fig. 76.1. Cópia em papel, editada por Alberto de Sampaio.
Fig. 77. Eduardo Rudge e Senhora, 1910. Negativo em vidro. Gelatina/prata, 10 x $8,5 \mathrm{~cm}$. Legenda original.

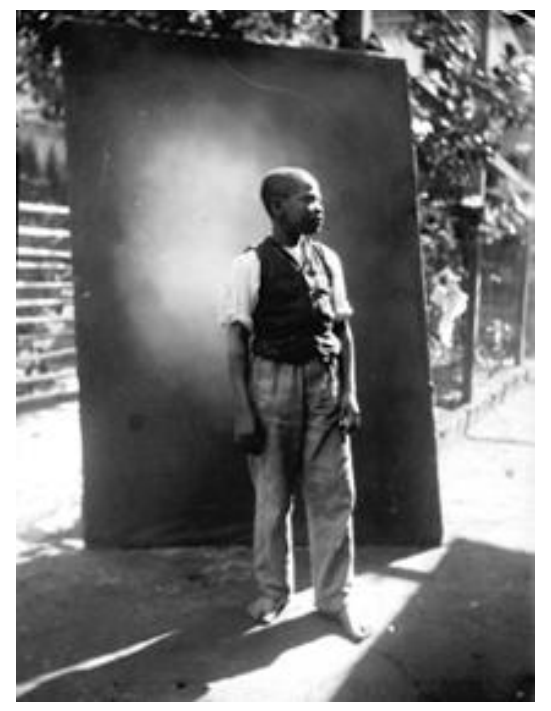

Fig. 78. Menino no quintal [1905-10]. Negativo em vidro. Gelatina/prata, $10 \mathrm{x}$ $8,5 \mathrm{~cm}$. Legenda atribuída.

Fig. 78.1. Cópia em papel, editada por Alberto de Sampaio.

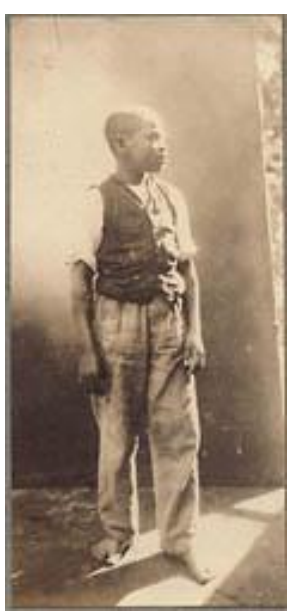




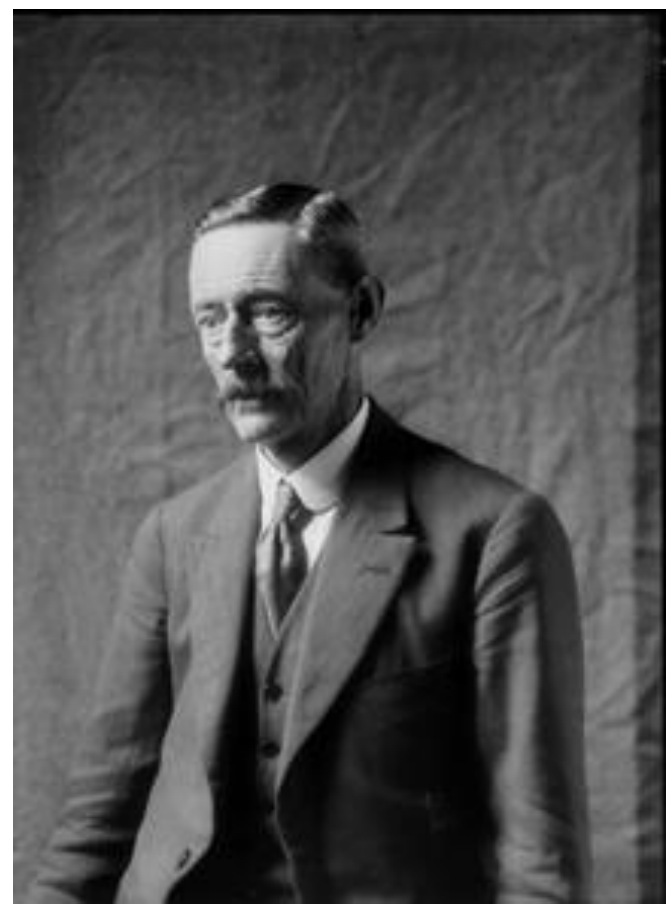

Fig. 79. Gustav Guillman [1905-14]. Negativo em vidro. Gelatina/prata, 12 × 16 $\mathrm{cm}$. Legenda atribuída.
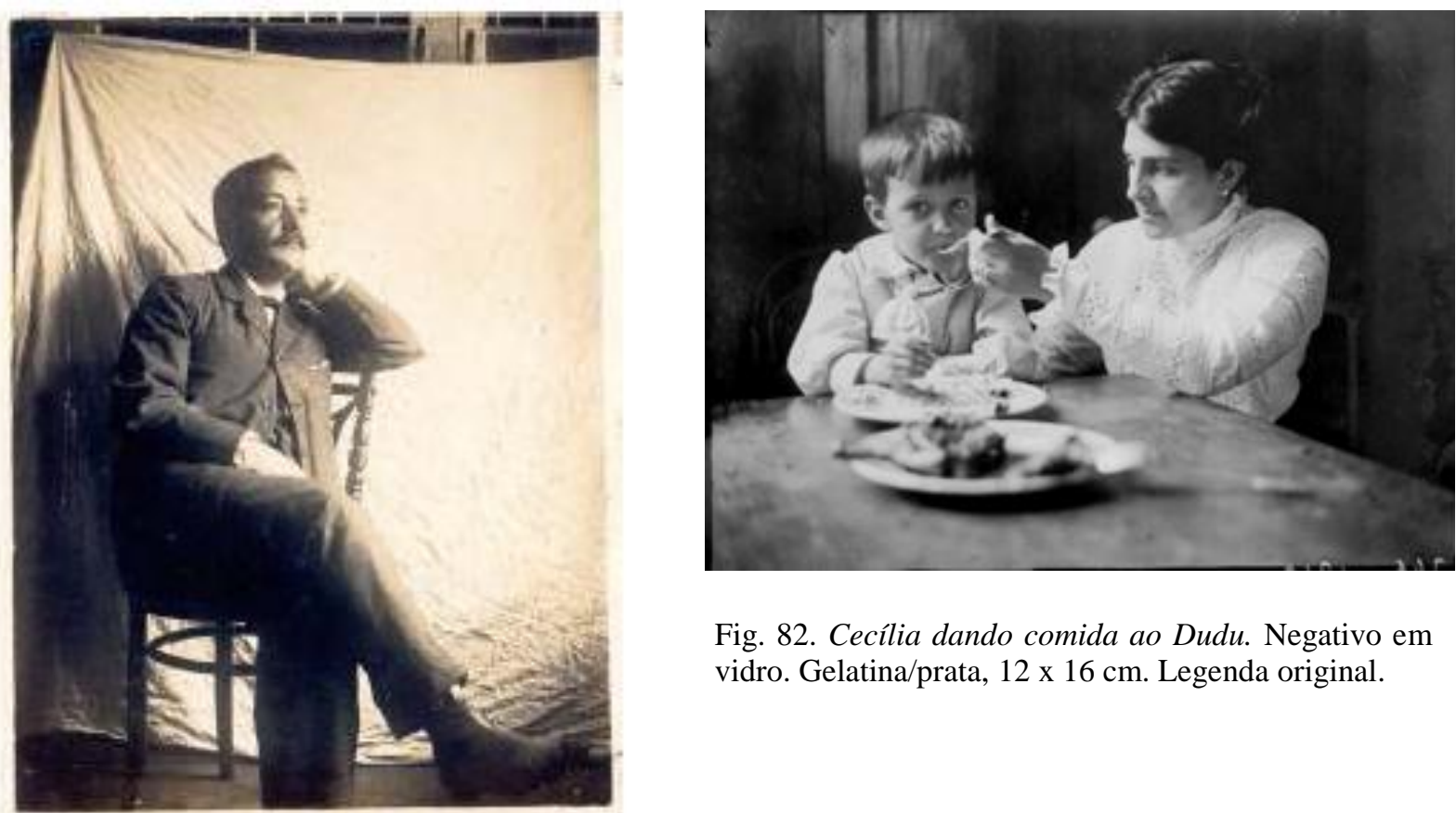

Fig. 82. Cecília dando comida ao Dudu. Negativo em vidro. Gelatina/prata, 12 x $16 \mathrm{~cm}$. Legenda original.

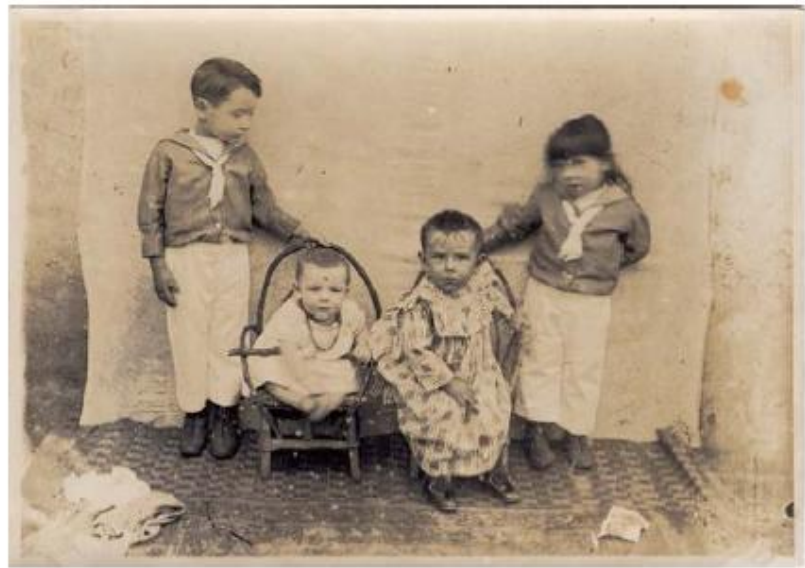

Fig. 80. Filhos de Francisco Brandão, s/d. (Covas, 2005: 54).

Fig. 81. Francisco Brandão, c. 1910. (Covas, 2005: 43). 


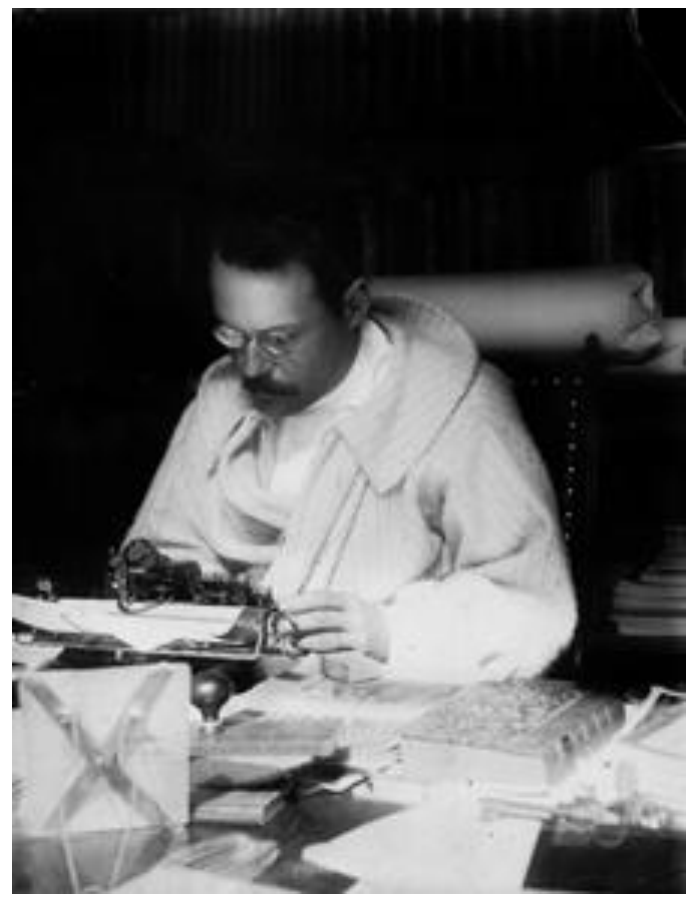

Fig. 83. Мeu retrato no escriptorio, 1907. Negativo em vidro. Gelatina/prata, 10 x 8,5 cm. Legenda original.

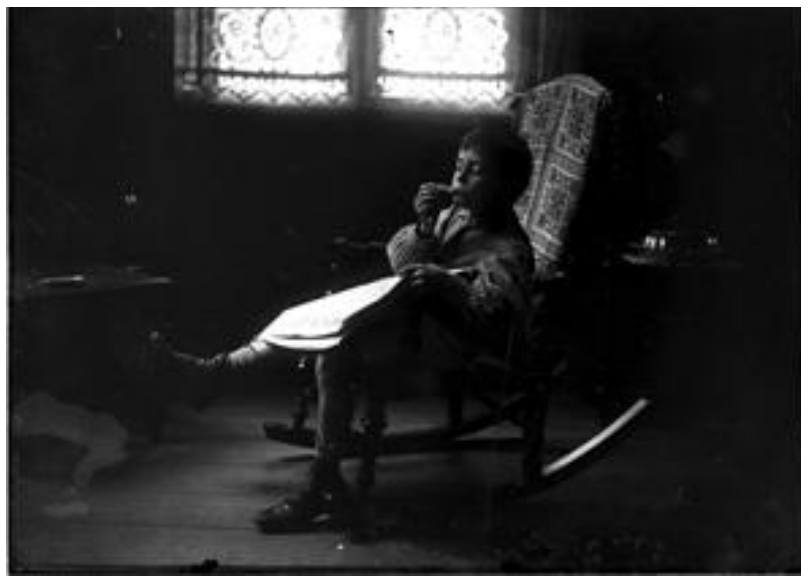

Fig. 85 Bento com charuto, c. 1905. Negativo em vidro. Gelatina/prata, 12 x $16 \mathrm{~cm}$. Legenda atribuída.

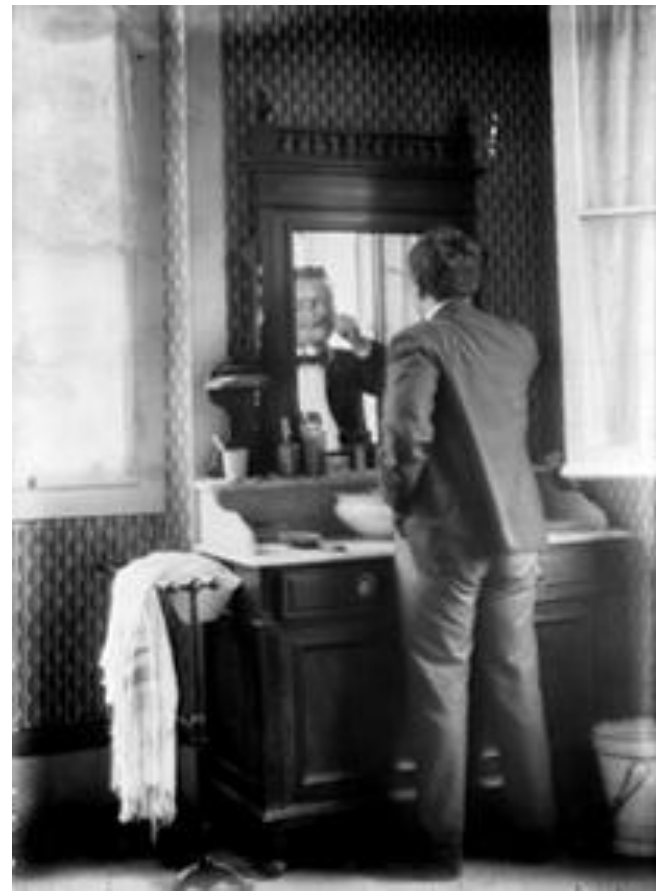

Fig. 84. Alberto no toillete, 1906. Negativo em vidro. Gelatina/prata, 12 × $16 \mathrm{~cm}$. Legenda original.

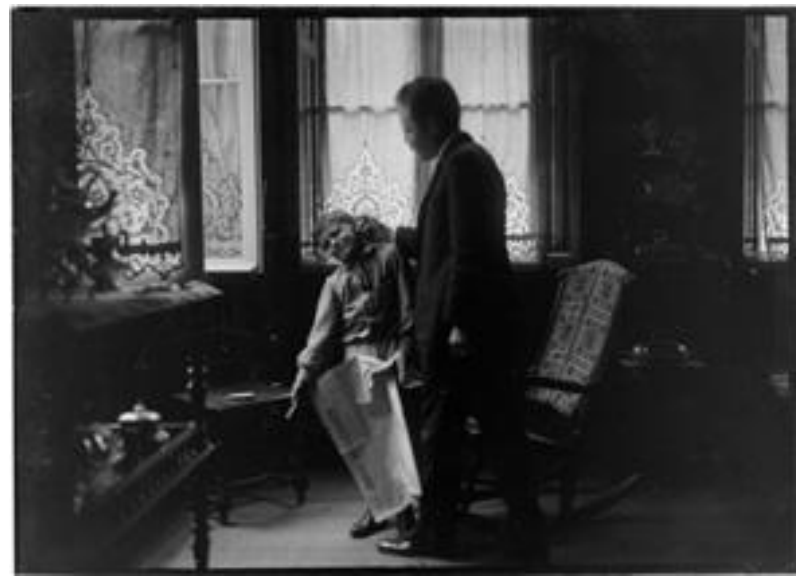

Fig. 86. Alberto e Bento, c. 1905. Negativo em vidro. Gelatina/prata, 12 x $16 \mathrm{~cm}$. Legenda atribuída. 


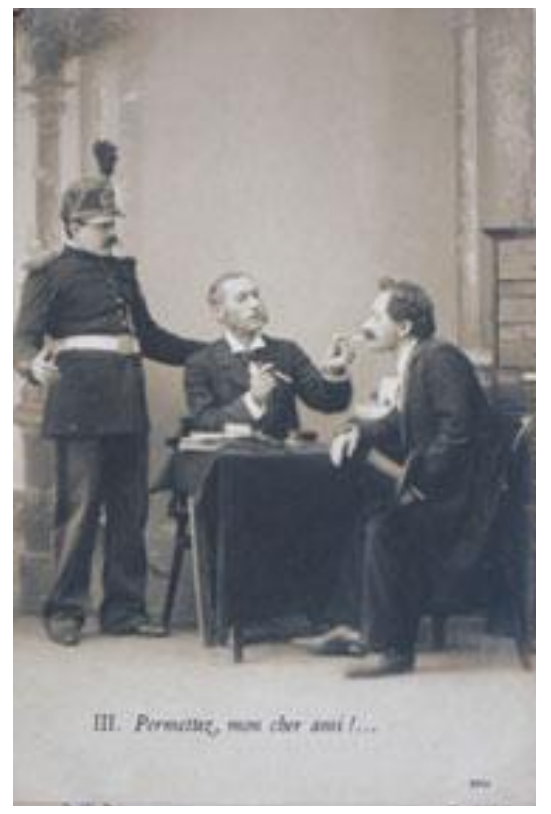

Fig. 87. Cartão postal [1902-04]. Pertence ao acervo de Alberto de Sampaio.

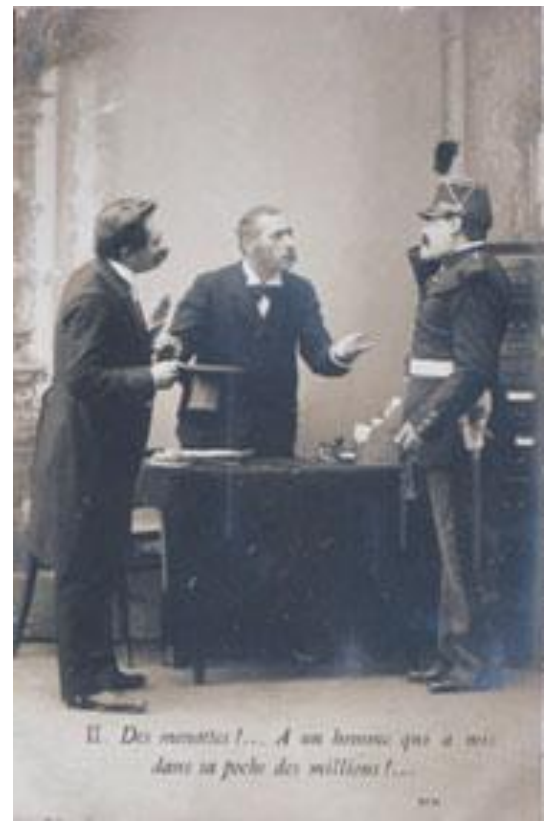

Fig. 89. Cartão postal [1902-04]. Pertence ao acervo de Alberto de Sampaio.

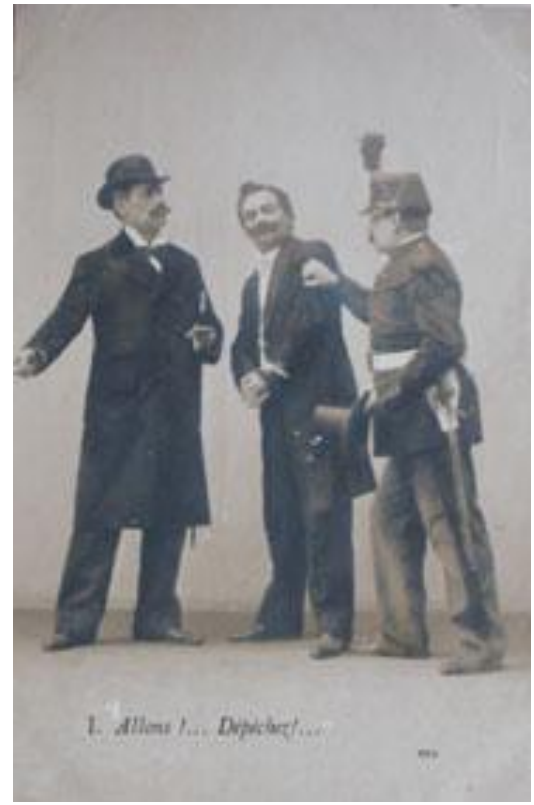

Fig. 88. Cartão postal [1902-04]. Pertence ao acervo de Alberto de Sampaio.

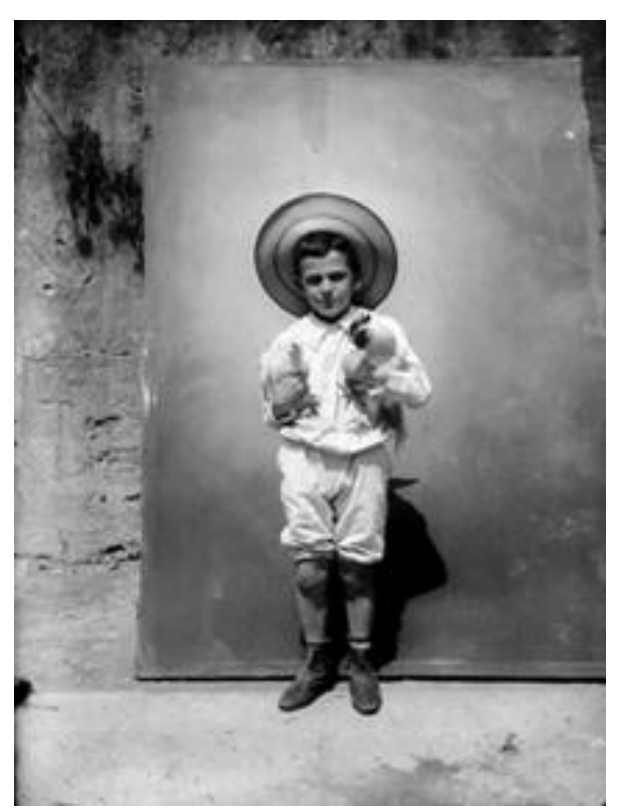

Fig. 90. John com os garnizés, 1905. Negativo em vidro. Gelatina/prata, 10 x 8,5 $\mathrm{cm}$. Legenda original. 


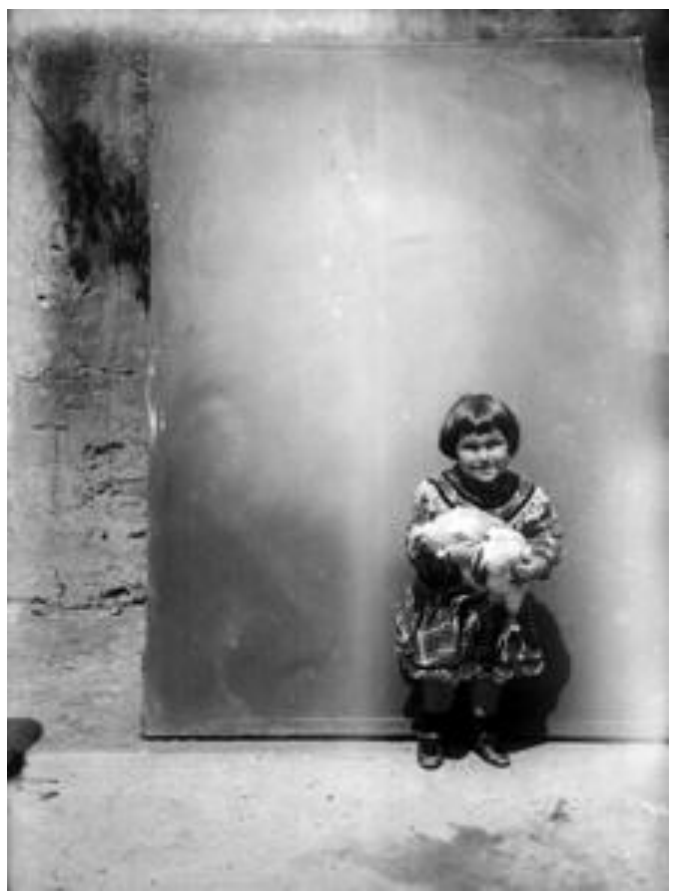

Fig. 91. Luluta com os garnizés, 1905.

Negativo em vidro. Gelatina/prata, 10 x 8,5 $\mathrm{cm}$. Legenda original.

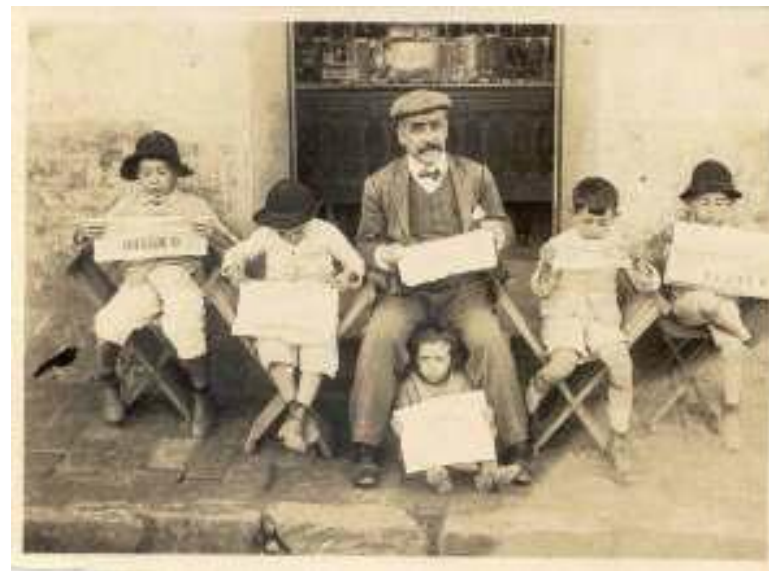

Fig. 93. Eduardo Brandão com filhos em frente à farmácia de sua propriedade (Covas, 2005: 76).

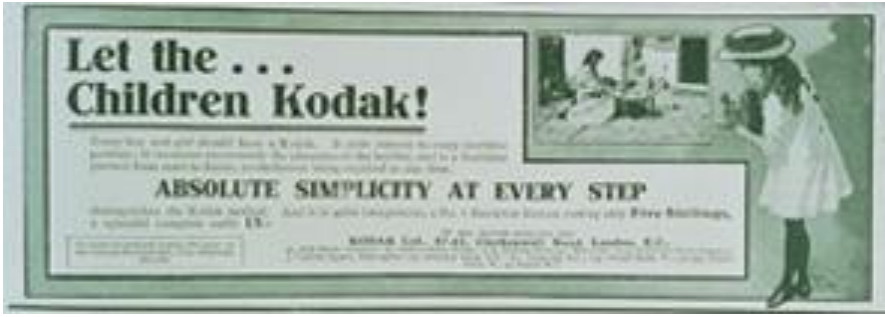

Fig. 94. Propaganda publicada na revista The Graphic, 31 de julho de 1909. 


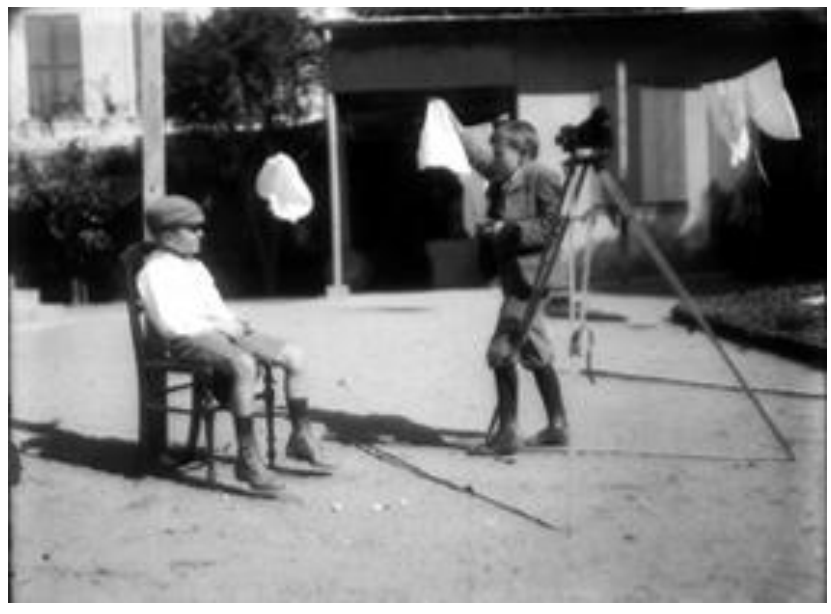

Fig. 95. Filhos de Alberto de Sampaio fotografando, c. 1905. Negativo em vidro. Gelatina/prata, 12 x $16 \mathrm{~cm}$. Legenda atribuída.

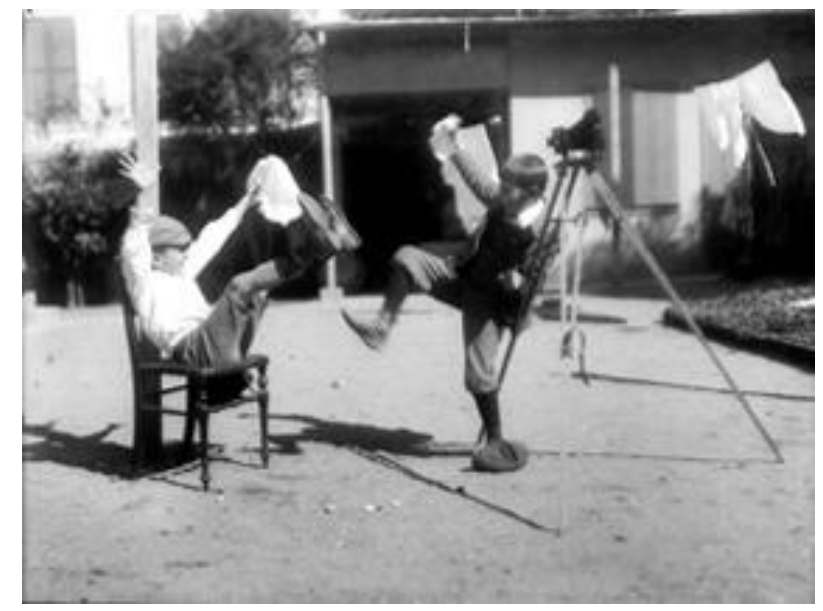

Fig. 96. Filhos de Alberto de Sampaio fotografando, c. 1905. Negativo em vidro. Gelatina/prata, 12 × $16 \mathrm{~cm}$. Legenda atribuída.

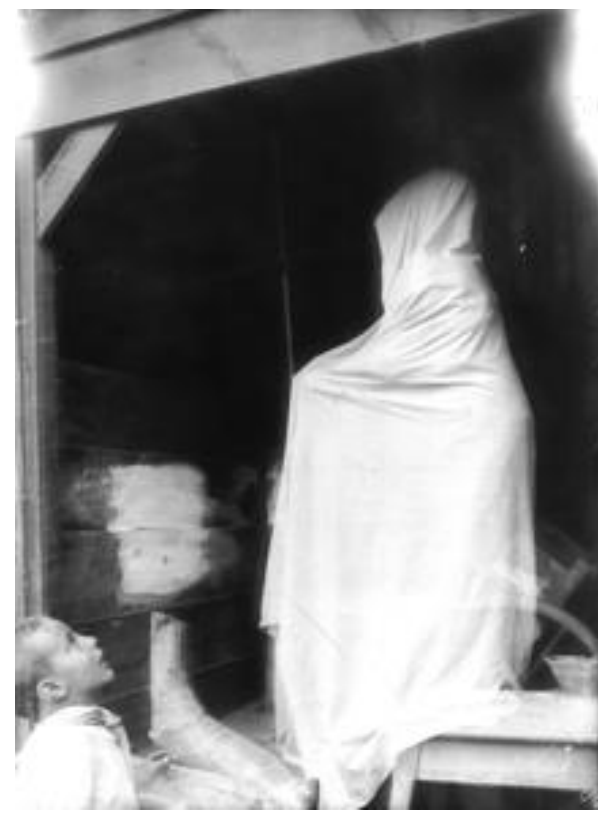

Fig. 97. Phantasma. Negativo em vidro. Gelatina/prata, 12 × $16 \mathrm{~cm}$. Legenda original.

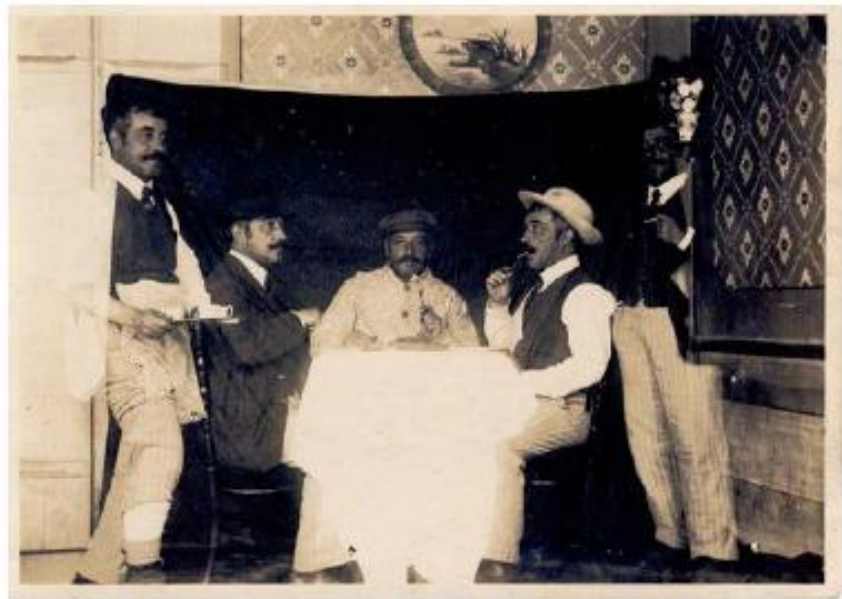

Fig. 98. Francisco Brandão, s/d (Covas, 2005: 76). 


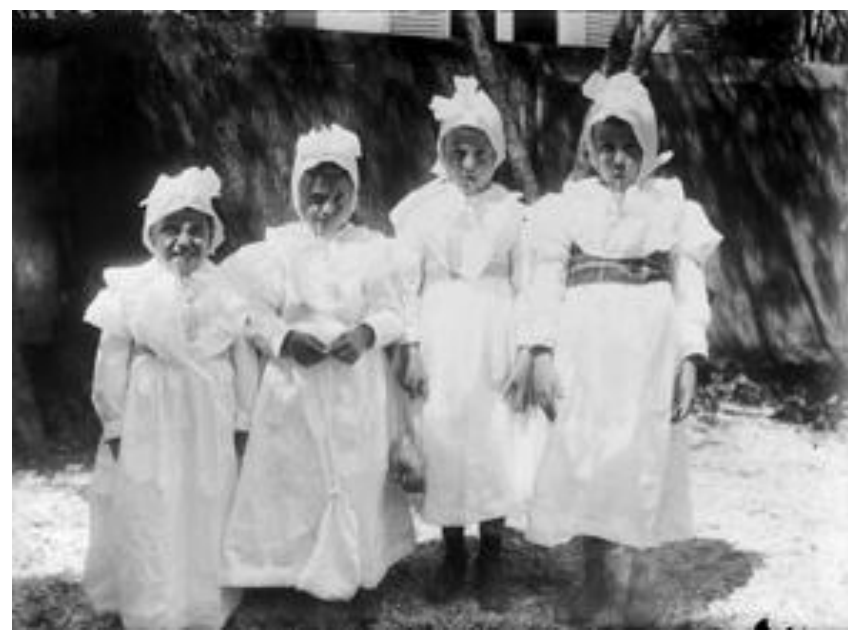

Fig. 99. Filhos de Alberto de Sampaio c. 1905. Negativo em vidro. Gelatina/prata, 12 x $16 \mathrm{~cm}$. Legenda atribuída.

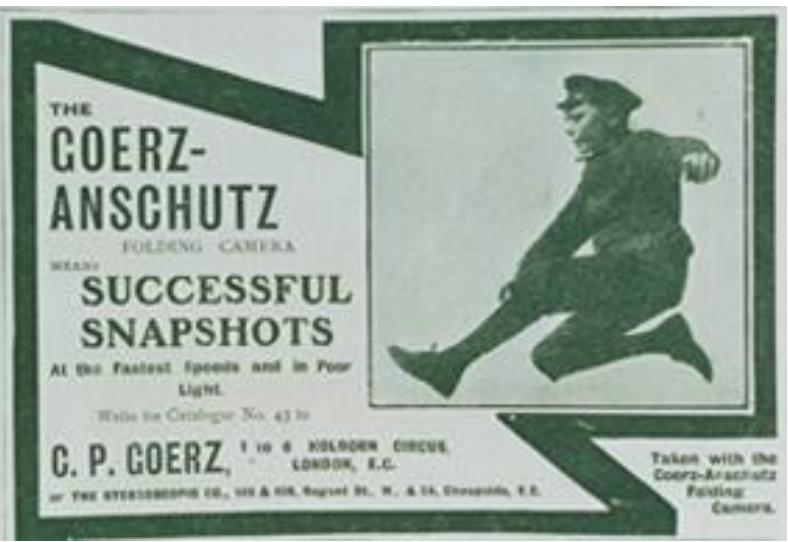

Fig. 100. Propaganda publicada na revista The Graphic, 9 de setembro de 1905.

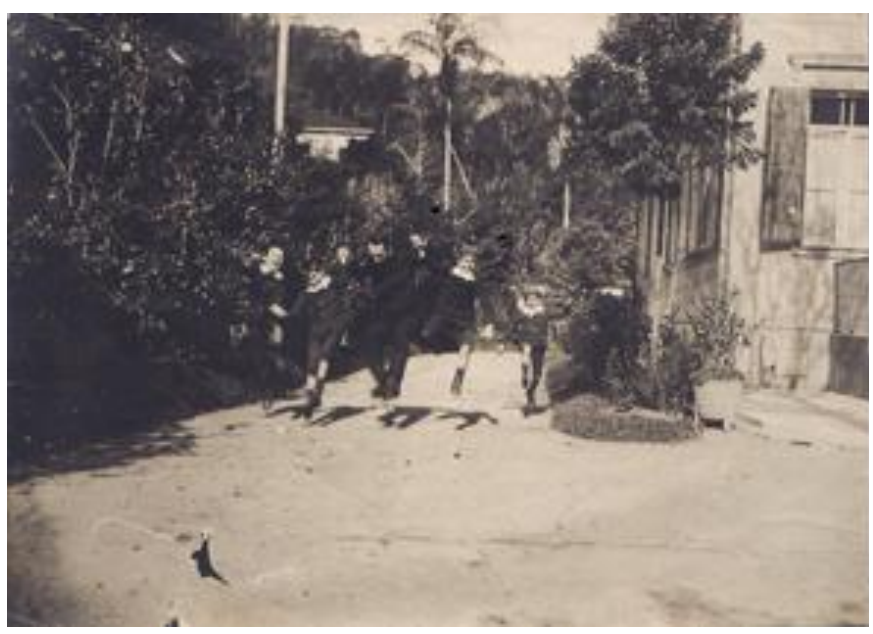

Fig. 101. Alberto e filhos no quintal, c. 1905. Cópia em papel, negativo de celulóide.

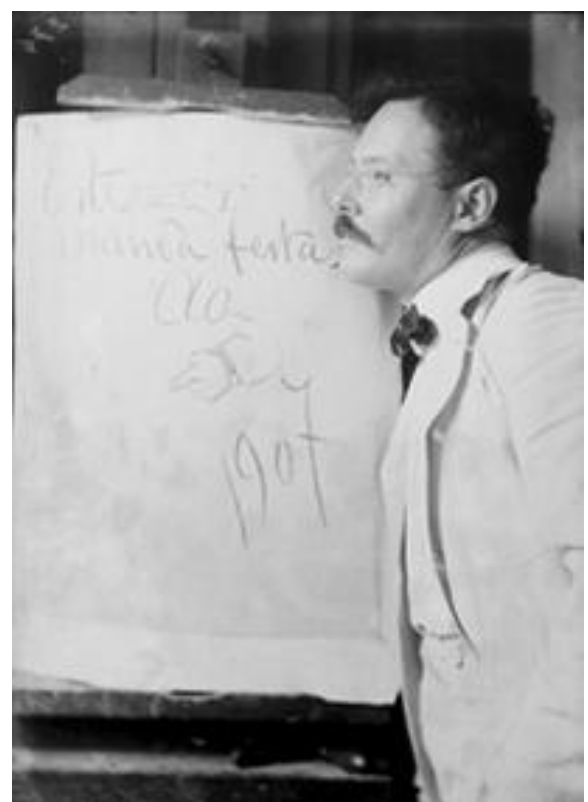

Fig 102. Alberto de Sampaio, 1907. Negativo em vidro. Gelatina/prata, $12 \mathrm{x}$ $16 \mathrm{~cm}$. Legenda atribuída. 


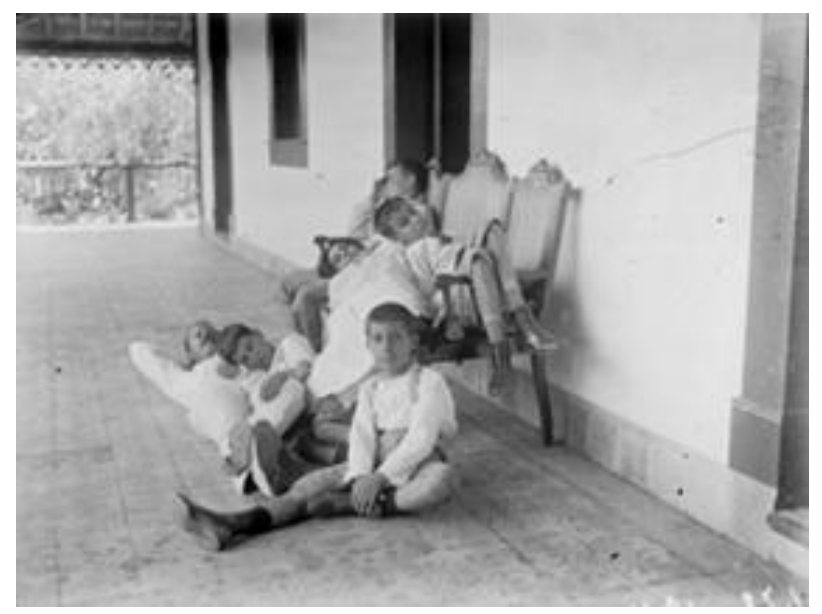

Fig. 103. Effeito do calor em Sta. Alda, 1911. Negativo em vidro. Gelatina/prata, 10 x 8,5 cm. Legenda original.

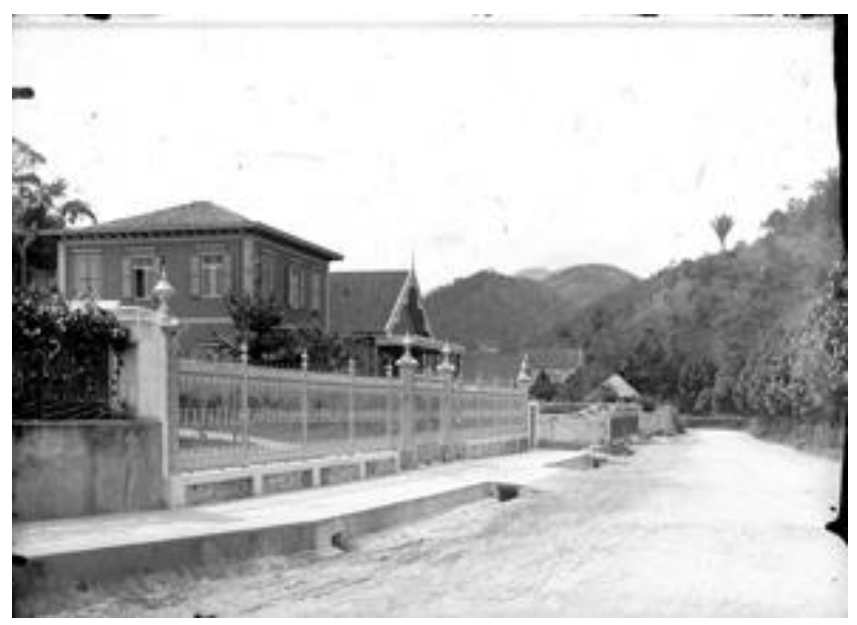

Fig. 105. Rua de Souza Franco, 1893. Negativo em vidro. Gelatina/prata, 12 x $16 \mathrm{~cm}$. Legenda original.

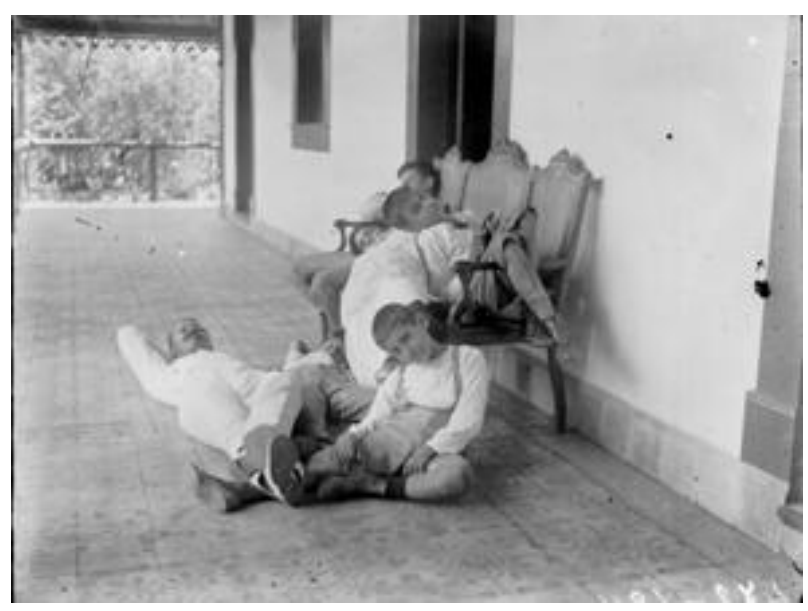

Fig. 104. Effeito do calor em Sta. Alda, 1911. Negativo em vidro. Gelatina/prata, 10 x 8,5 cm. Legenda original.

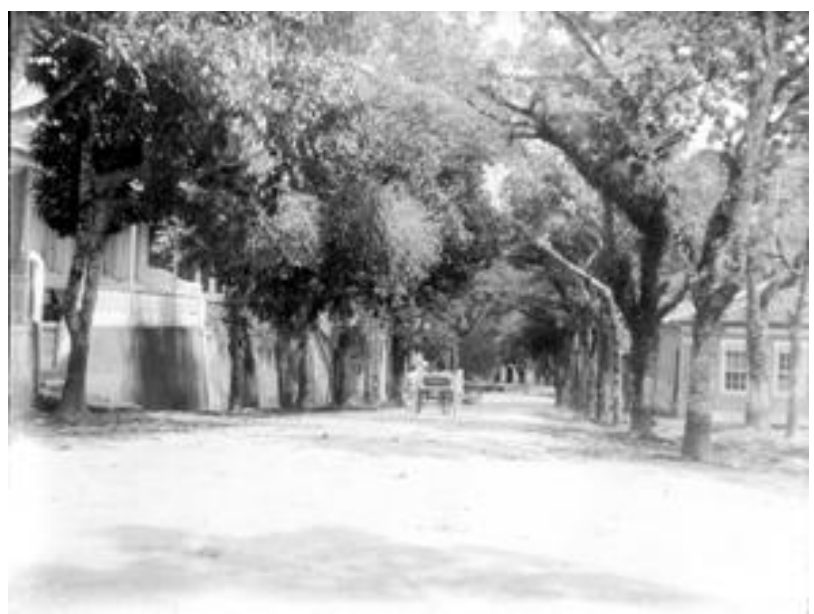

Fig. 106. Rua Marechal Deodoro, 1907. Negativo em vidro. Gelatina/prata, 10 x 8,5 cm. Legenda original. 


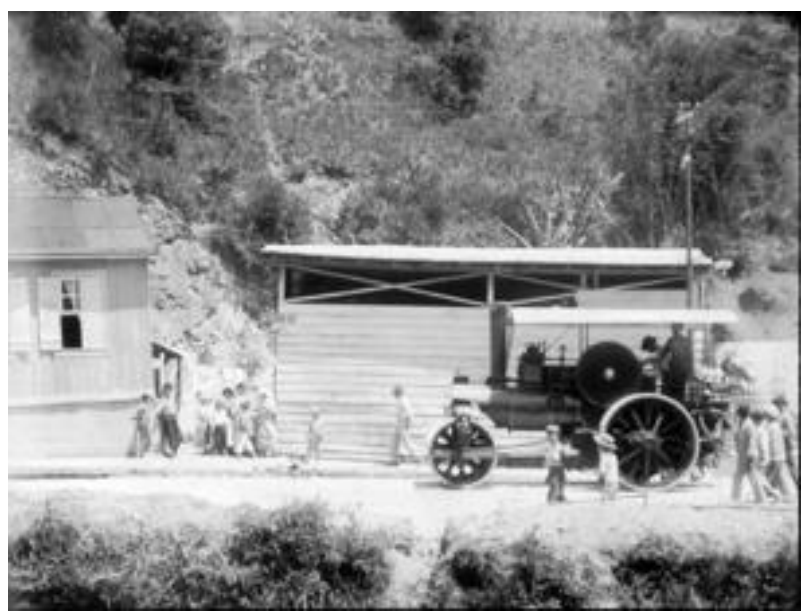

Fig. 107. Compressor de Macadam, 1905. Negativo em vidro. Gelatina/prata, $10 \times 8,5 \mathrm{~cm}$. Legenda original.

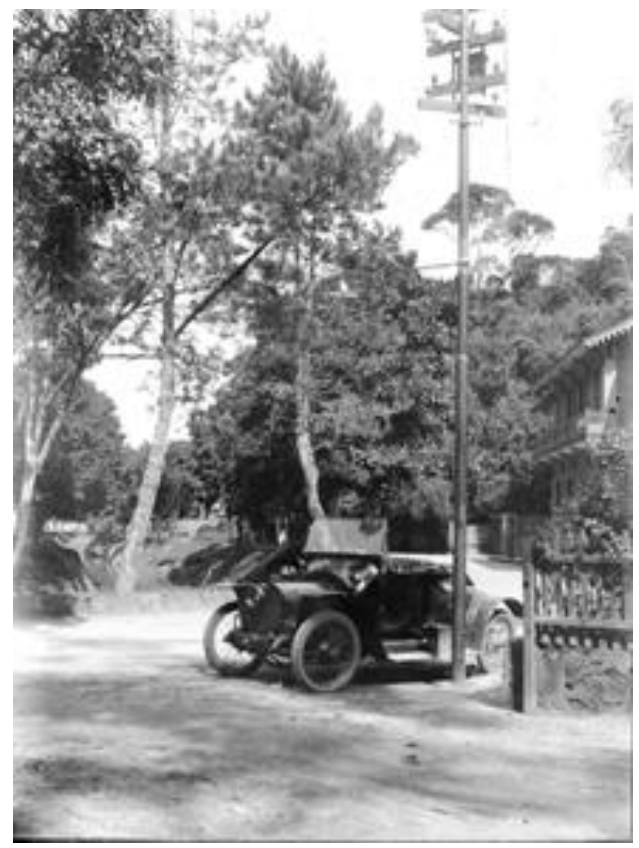

Fig. 108. Automóvel nas Duchas, 1914. Negativo em vidro. Gelatina/prata, 10 x $8,5 \mathrm{~cm}$. Legenda original.

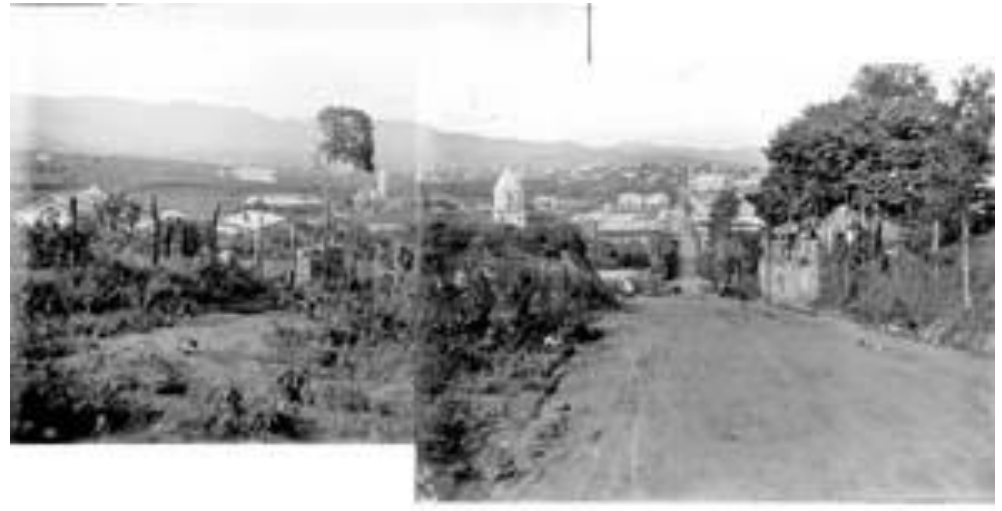

Fig. 109. Bello Horizonte, 1910. Negativo em vidro (duas chapas). Gelatina/prata, $10 \times 8,5 \quad \mathrm{~cm}$. Legenda original. 


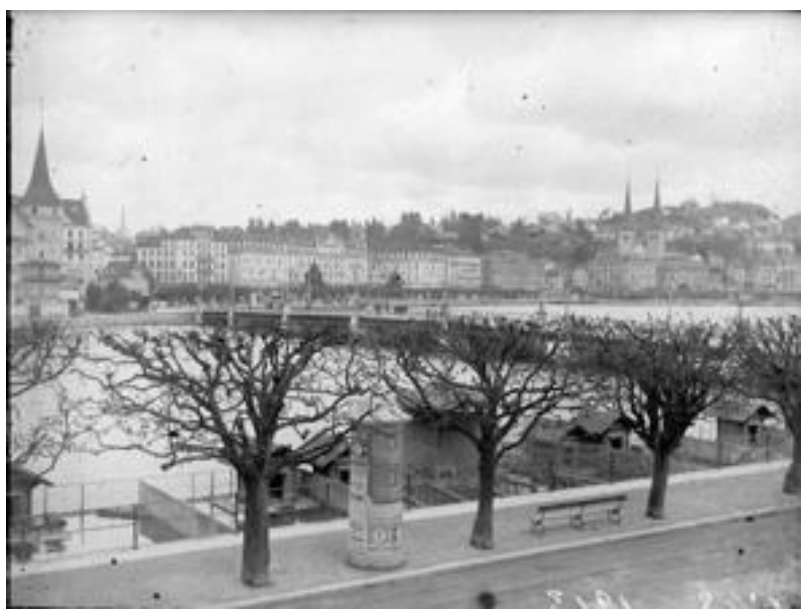

Fig. 110. A casa dos cysnes e a ponte nova de Lucerne, 1913. Negativo em vidro. Gelatina/prata, 10 x $8,5 \mathrm{~cm}$. Legenda original.

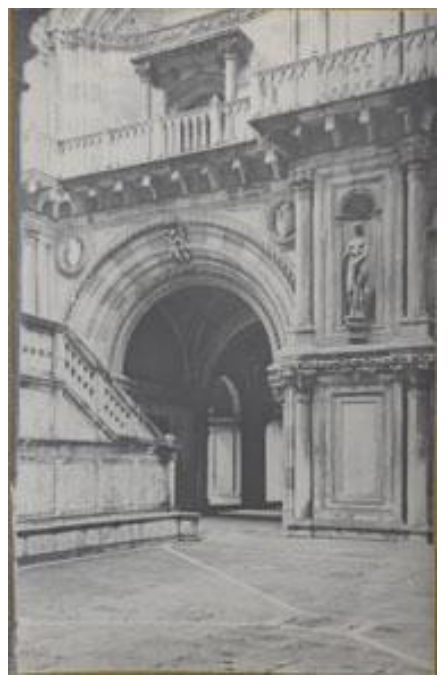

Fig. 112. Interior do pateo do Palácio dos Dodge. A esquerda a balaustrada da Scala dei Giganti, 1913. Cópia em papel, negativo de celulóide. Legenda original.

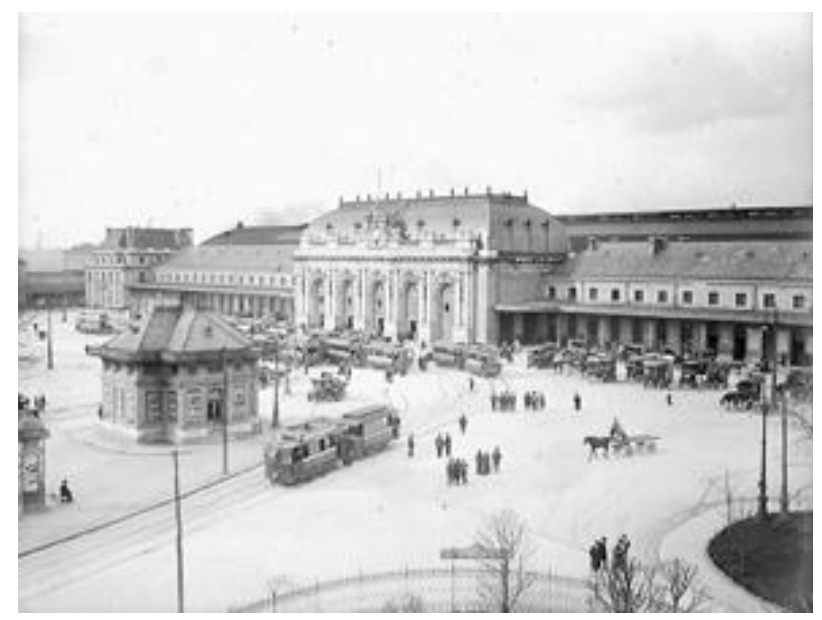

Fig. 111. Estação Central do caminho de ferro em Milão, 1913. Negativo em vidro. Gelatina/prata, $10 \mathrm{x}$ $8,5 \mathrm{~cm}$. Legenda original.

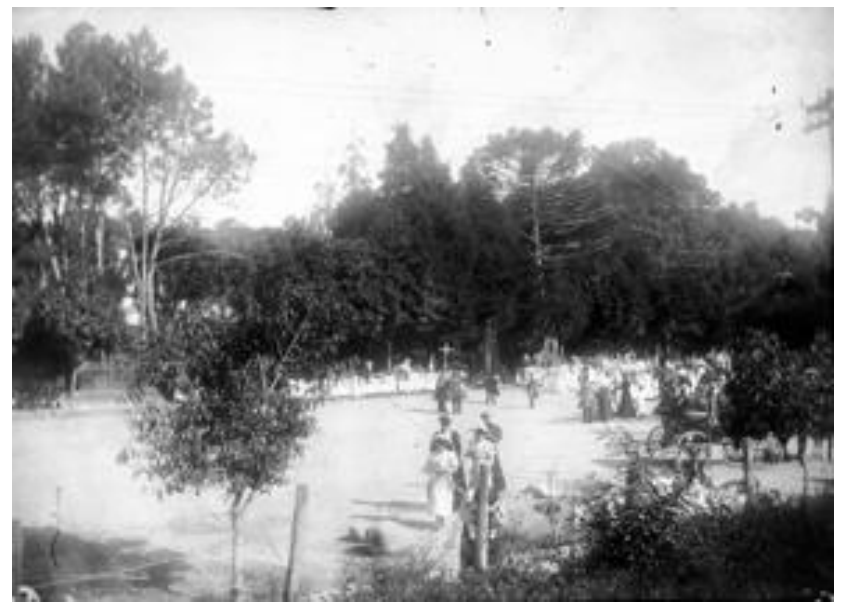

Fig. 113. Procissão em Petrópolis, 1899. Negativo em vidro. Gelatina/prata, 10 x $8,5 \mathrm{~cm}$. Legenda original.

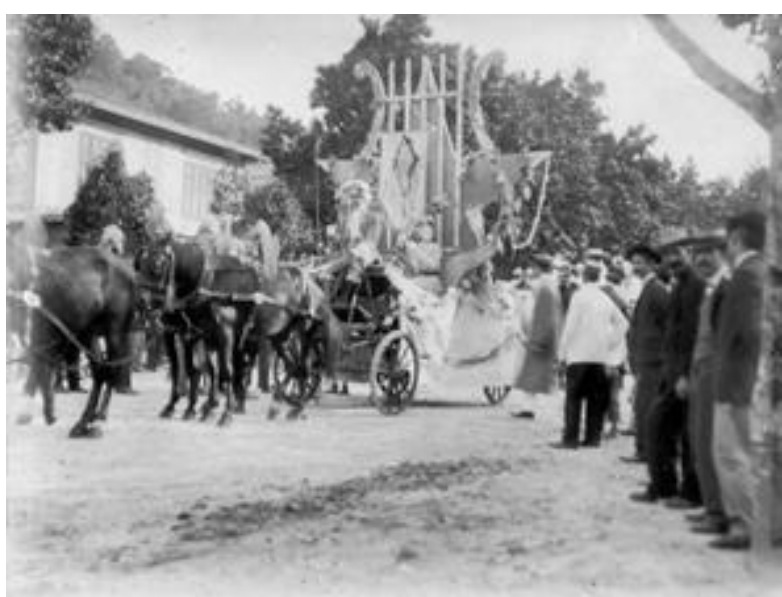

Fig. 114. Carro standarte, carnaval, 1907. Negativo em vidro. Gelatina/prata, 10 x $8,5 \mathrm{~cm}$. Legenda original. 


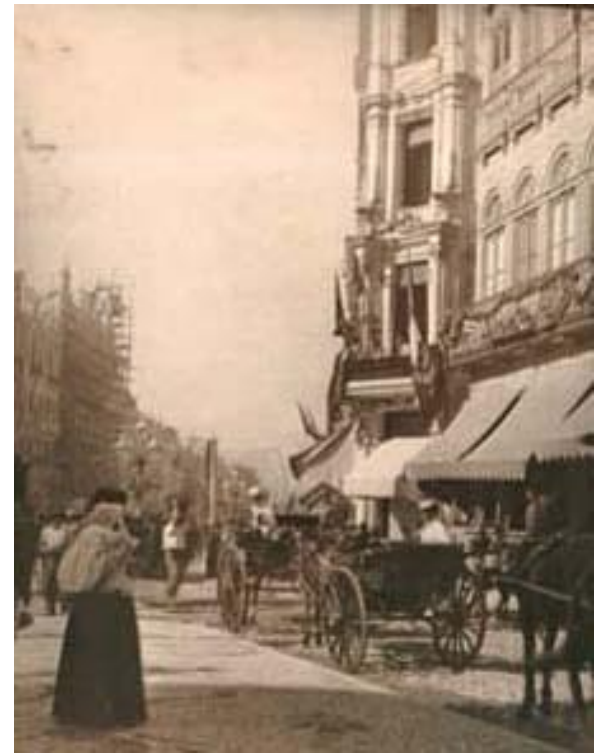

Fig. 115. Rua dos Ourives, 1906. Cópia em papel, negativo de celulóide. Legenda atribuída.

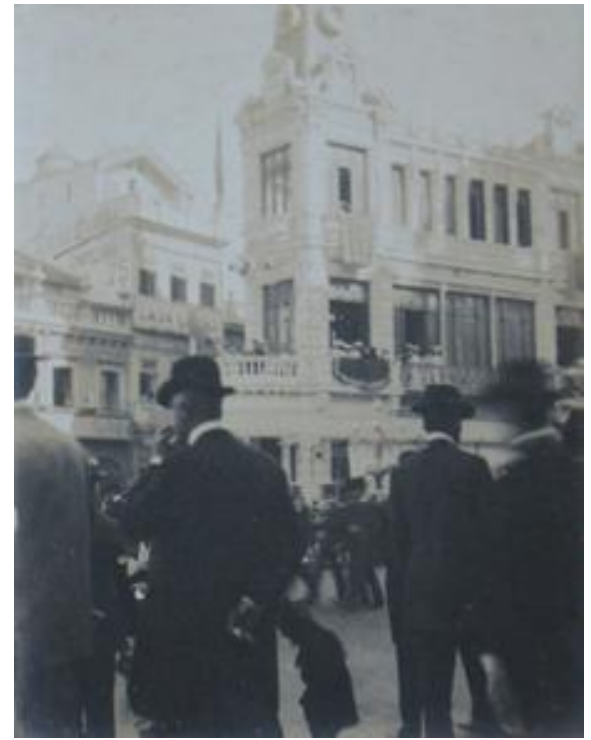

Fig. 116. Avenida Central, 1906. Cópia em papel, negativo de celulóide. Legenda atribuída.

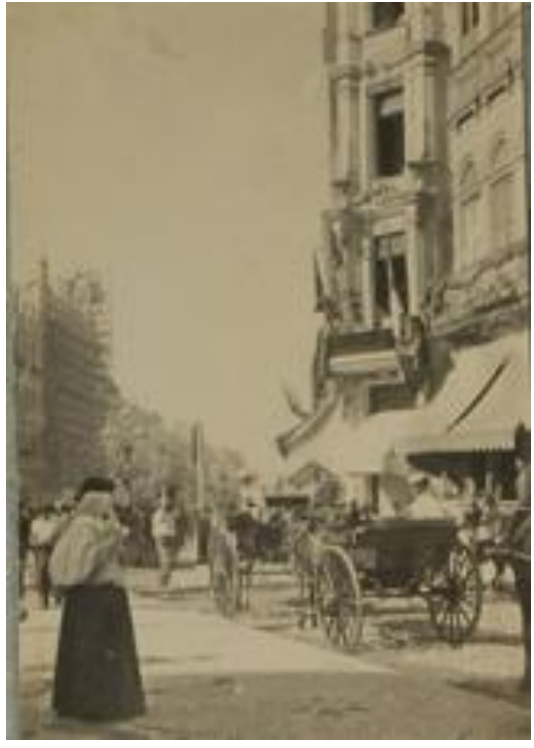

Fig. 115.1. Rua dos Ourives, 1906. Cópia em papel, negativo de celulóide. Legenda atribuída.

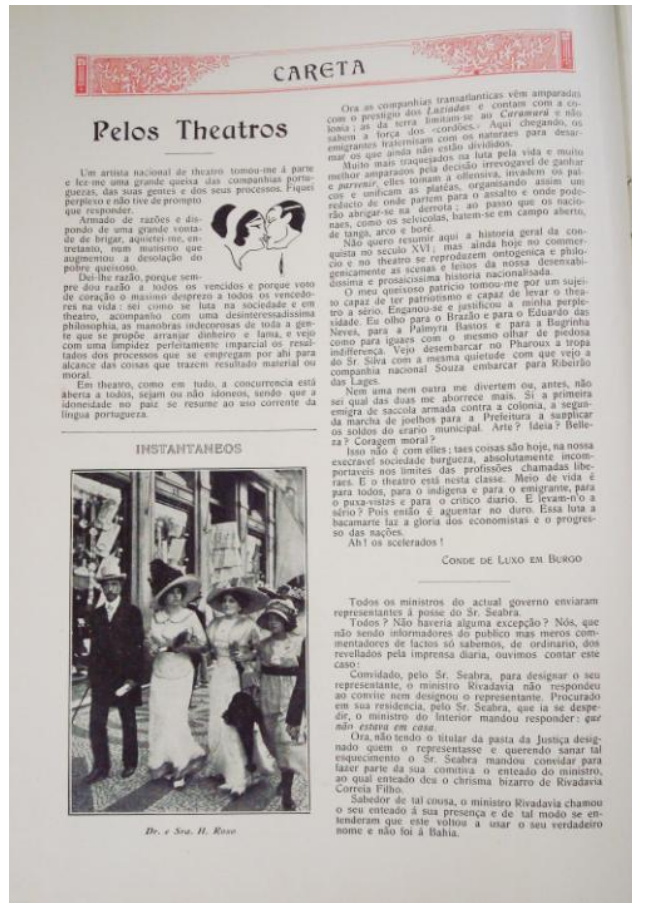

Fig. 117. Dr. e sra. H. Roxo. Revista Careta, 13 de abril de 1912. 


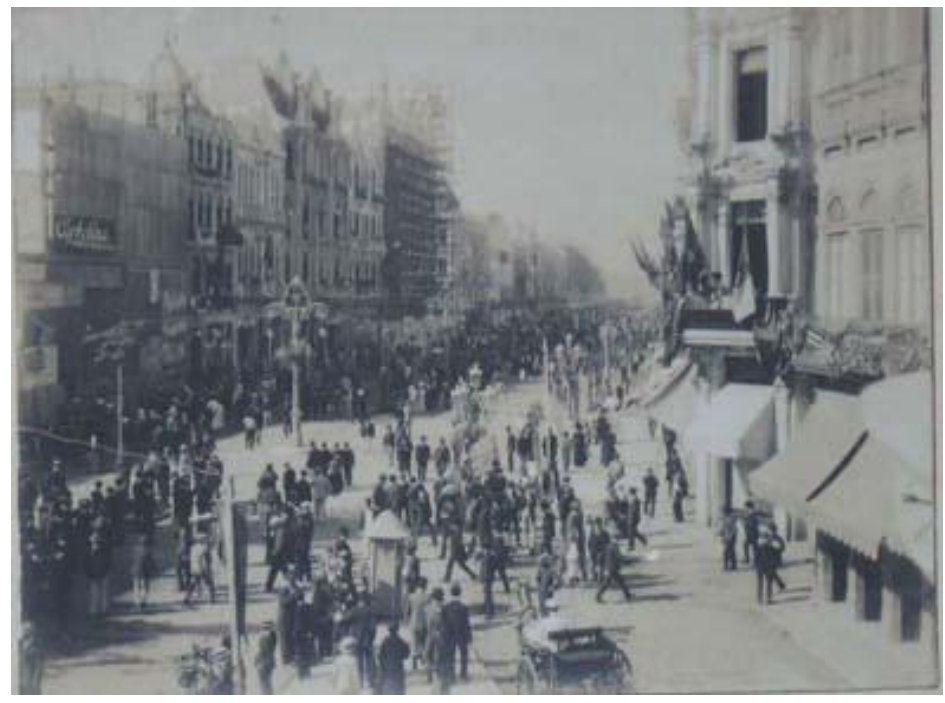

Fig. 118. Avenida Central, 1906. Cópia em papel, negativo de celulóide. Legenda atribuída.
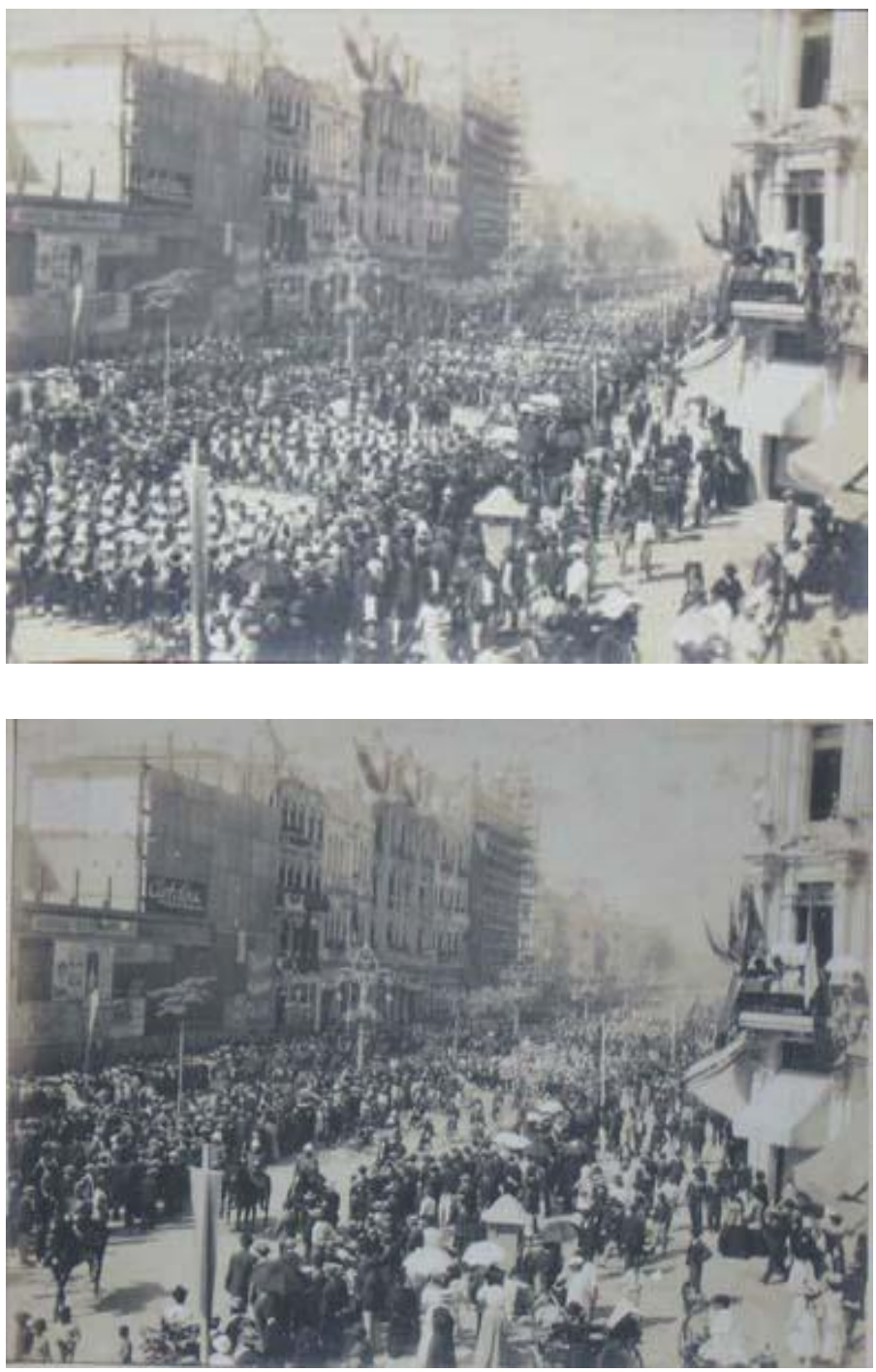

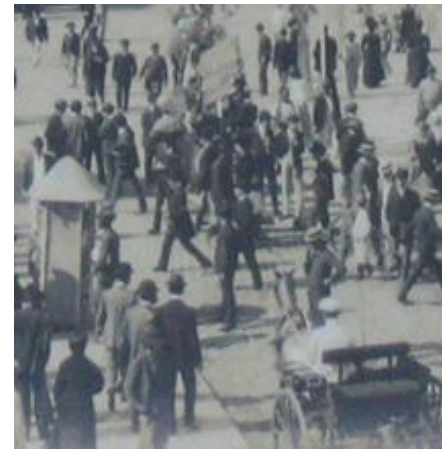

Fig. 118.1. Detalhe, homem que segura placa, "Calçados quase de graça”.
Fig. 119. Avenida Central, 1906. Cópia em papel, negativo de celulóide. Legenda atribuída.
Fig. 120. Avenida Central, 1906. Cópia em papel, negativo de celulóide. Legenda atribuída. 


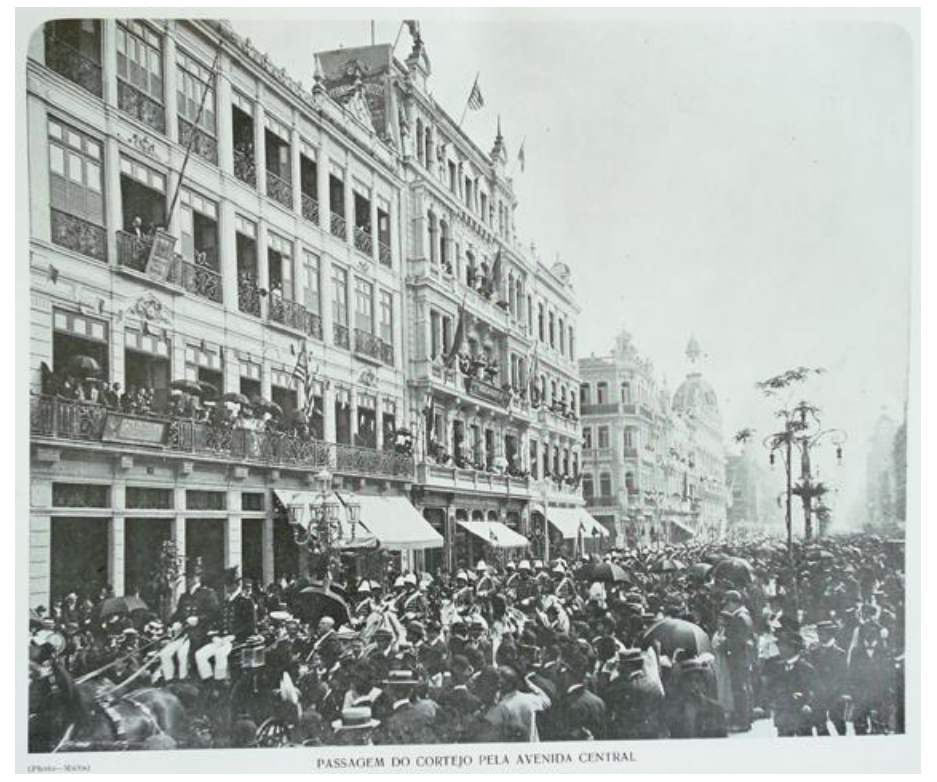

Fig. 121. Passagem do cortejo pela Avenida Central. Fotografia de Augusto Malta. Revista Kosmos, julho de 1906.
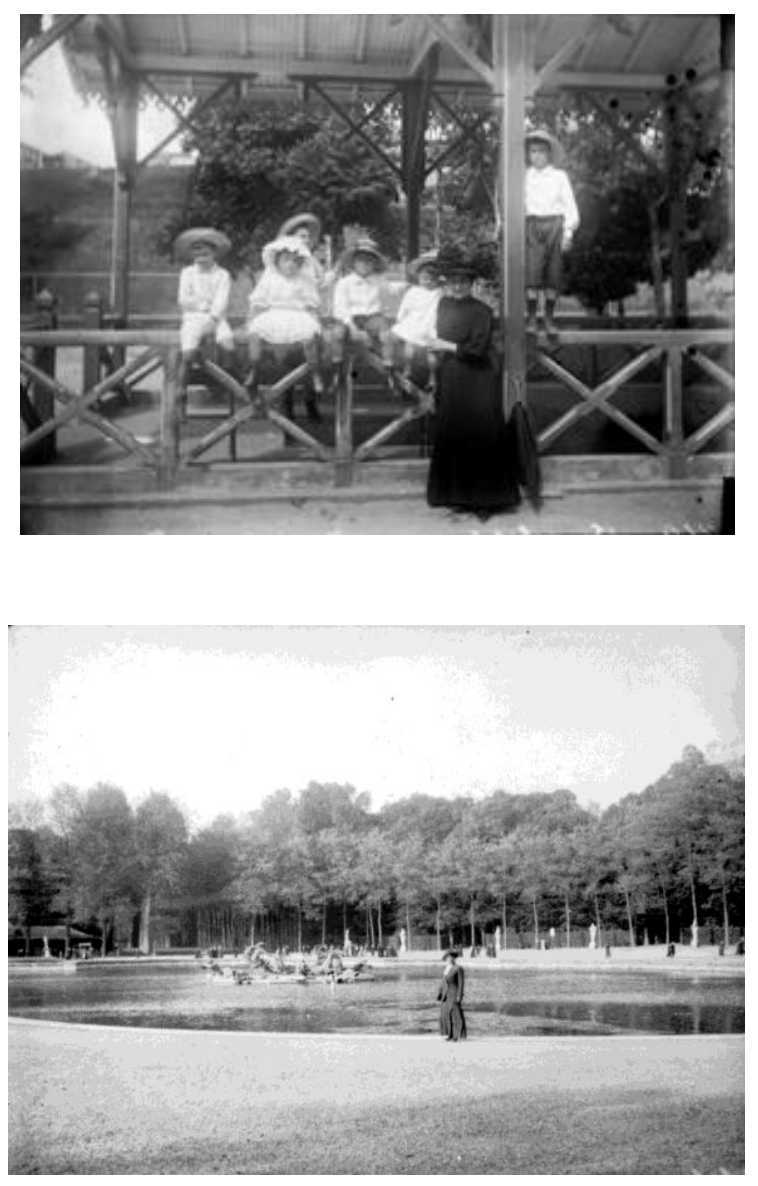

Fig. 123. Bassin D'Appolon. Negativo em vidro. Gelatina/prata, 6 x 4,5 cm. Legenda original.
Fig. 122. Grupo, meninos na fonte. Negativo em vidro. Gelatina/prata, 10 x 8,5 $\mathrm{cm}$. Legenda original.

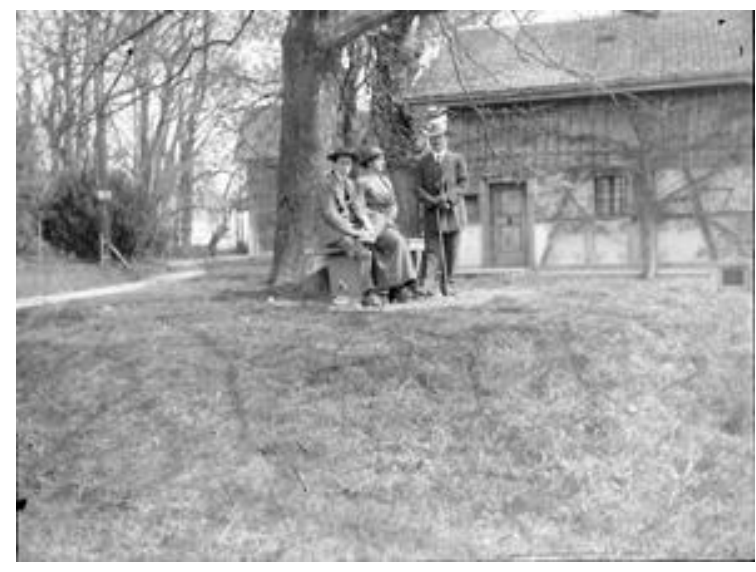

Fig. 124. Grupo em Lucerne. Negativo em vidro. Gelatina/prata, 10 x $8,5 \mathrm{~cm}$. Legenda original. 


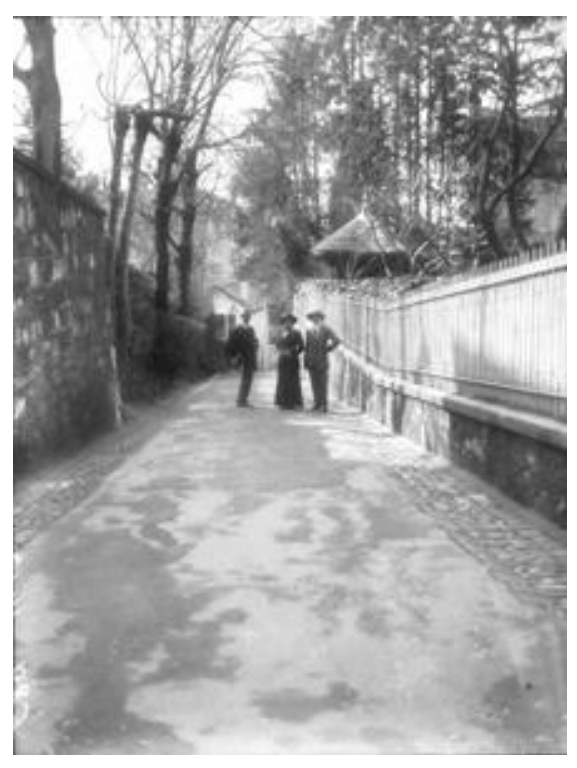

Fig. 125. Uma viella em Lausanne. Negativo em vidro.

Gelatina/prata, 10 x 8,5 cm. Legenda original.
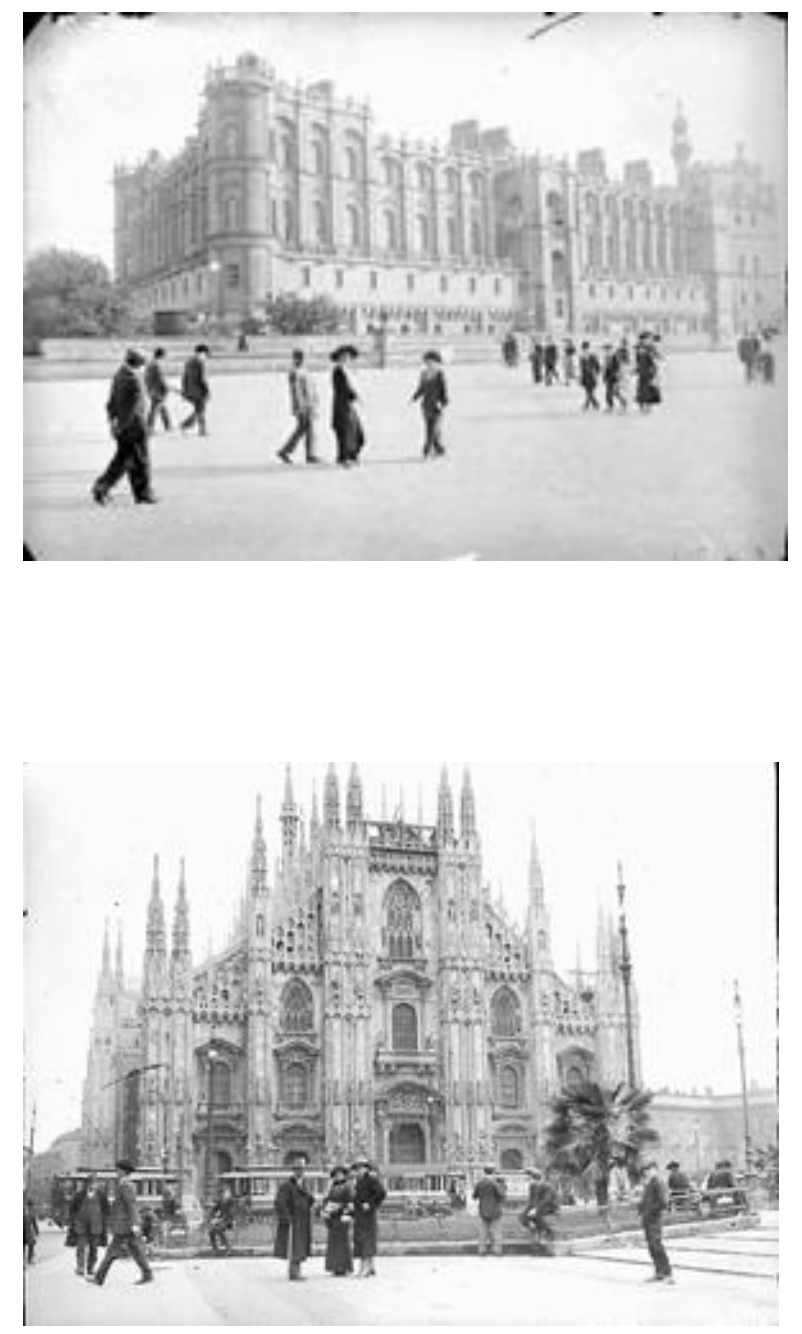

Fig. 126. Castello de Saint-Germain-en-Laye. Negativo em vidro. Gelatina/prata, 10 x 8,5 cm. Legenda original.
Fig. 127. O Duomo de Milão. Negativo em vidro. Gelatina/prata, 10 x 8,5 cm. Legenda original. 


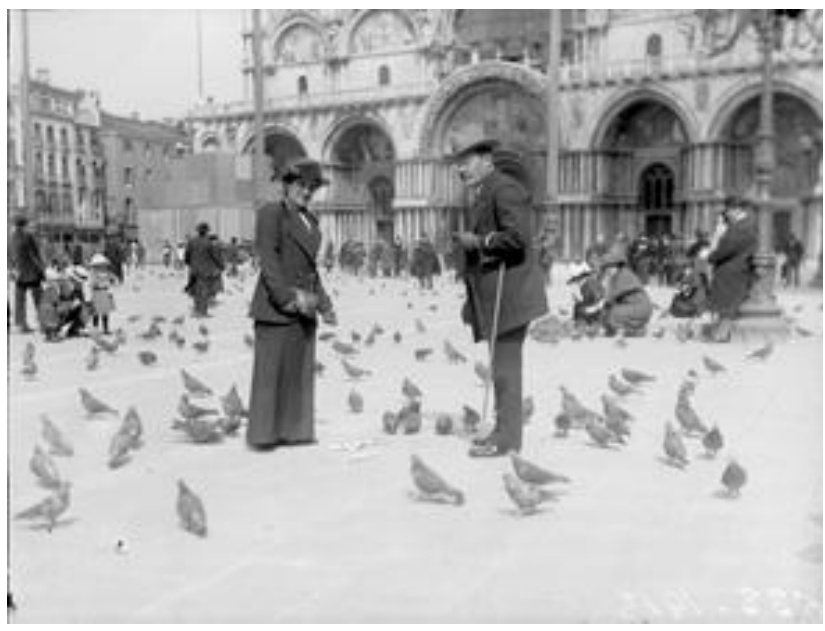

Fig. 128. Eu e Cecília com os pombos, S. Marcos [Veneza]. Negativo em vidro. Gelatina/prata, $10 \mathrm{x}$ $8,5 \mathrm{~cm}$. Legenda original.

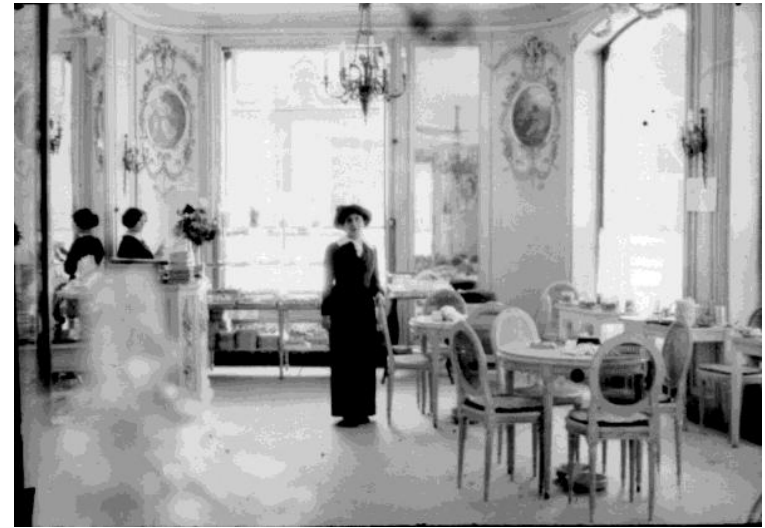

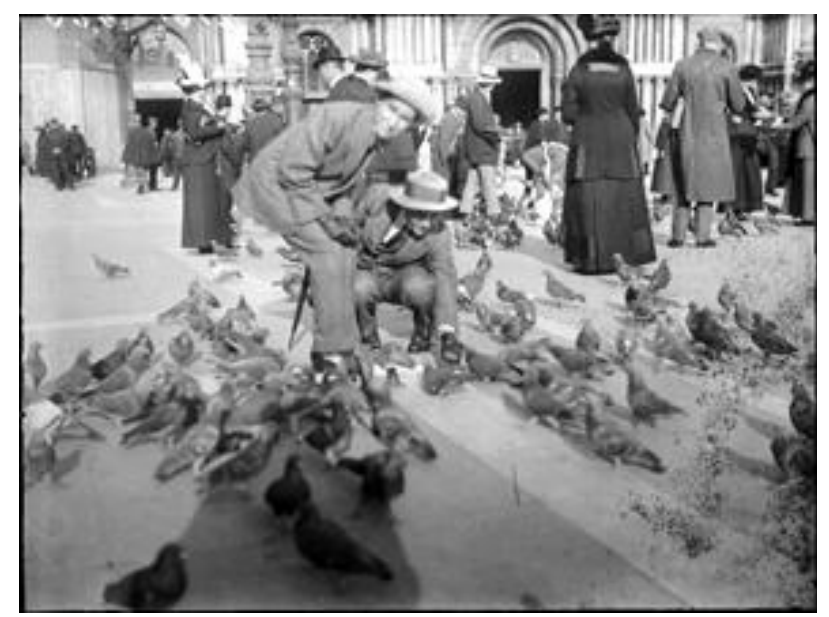

Fig. 129. John e Álvaro com os pombos [Veneza]. Negativo em vidro. Gelatina/prata, 10 x 8,5 cm. Legenda original.

Fig. 130. Cecília dentro da confeitaria Pamela. Negativo em vidro. Gelatina/prata, 6 x 4,5 cm. Legenda original. 